NUT OF LAW

DIGITAL REPOSITORY

Faculty Book Display Case

School of Law

1970

\title{
Cases and Materials on Contracts
}

Robert Desiderio

University of New Mexico - School of Law, desiderio@law.unm.edu

Frederick M. Hart

University of New Mexico - School of Law, hart@law.unm.edu

Follow this and additional works at: https://digitalrepository.unm.edu/law_facbookdisplay

Part of the Law Commons

\section{Recommended Citation}

Desiderio, Robert and Frederick M. Hart. "Cases and Materials on Contracts." (1970): 240 pages. https://digitalrepository.unm.edu/ law_facbookdisplay/195

This Book is brought to you for free and open access by the School of Law at UNM Digital Repository. It has been accepted for inclusion in Faculty NMT Book Display Case by an authorized administrator of UNM Digital Repository. For more information, please contact amywinter@unm.edu. 
Cases and Material on

\title{
CONTRACTS
}

\author{
by \\ Robert J. Desiderio \\ Assistant Professor of Law \\ University of New Mexico \\ and \\ Frederlck M. Hart \\ Professor of Law \\ University of New Mexico
}

No rights reserved

Ist Edition

1969-1970 
I. Introduction

Should a person always keep his word? for example, if you are employed and have sufficlent money to meet the needs of your famlly, you may well sign a piedge to make a charitable contribution each month to the United Fund or to some specific charity. If you lose your job, or incur unexpected expenses, fulfilliment of your promise might deprive your family of food, clothing, or other necessities. Or, look at another situation: a father promises to take his children to the circus. Just before they are to depart, he recelves a call from his employer asking him to come to the office to complete some work. Or again, a husband promises to give his wife a certain allowance each week to run the household. Is he bound to continue if he belleves that she is not using the money wisely?

The law of contracts asks the same basic question with a different twist. The issue is not necessarlly whlch promises should be kept, but rather which promise should society enforce and how should society enforce them. But why is society concerned with whether people keep their promise? is it because people ought to keep promises: it being a misuse of the communication abillities of humans to promise something and then not perform? Is it for economic reasons: promises are necessary for the business world to function smoothly? is it to prevent disorder in the community: to give people a method of righting a "wrong" other than by beating the promise breaker over the head with a club?

Consider the following article by Professor Farnsworth, 69 Col.L. Rev. 576 (1969). 


\section{THE PAST OF PROMISE: AN HISTORICAL INTRODUCTION TO CONTRACT}

\section{E. ALLAN FARNSWORTH*}

\section{INTRODUCTION}

In William Golding's compelling parable of the origins of society, Lord of the Flies, ${ }^{1}$ a group of English schoolboys, stranded on a tropical island, passes the time before rescue in hunting, building shelters, framing rudimentary rules of order, quarreling over vital possessions, and, in the end, fighting and killing one another. But in their society they do not, as far as we are told, bargain for the exchange of each other's promises. In this their experience mirrors that of man as a whole, who has shown little concern with such matters for most of his quarter of a million years existence. Oliver Wendell Holmes, Jr., casually dismissed inquiry into the origins of promise with the observation that "to explain how mankind first learned to promise, we must go to metaphysics, and find out how it ever came to frame a future tense."2 Yet both historians and anthropologists tell us that more than a future tense was required before man began to use promises. An inquiry into how he survived without promise, and how he came to use it, affords a useful perspective for the study of promise in our own society.

Every human society relies to some extent upon cooperation among its members to achieve social purposes. Ludwig von Mises put it concisely: "Society is concerted action, cooperation." 3 In order to obtain that cooperation, our own society puts its faith in a system that we call "capitalism" or, with a touch of euphemism, "free enterprise." Although it has since been refined and revised, there is no more forceful statement of the central assumption of this system than that contributed in 1776 by Adam Smith:

[M] an has almost constant occasion for the help of his brethren, and it is vain for him to expect it from their benevolences only. He will be more likely to prevail if he can interest their self-love in his favour, and shew them that it is for their own advantage to do for him what he requires of them. Whoever offers to another a bargain of any kind, proposes to do this. Give me that which I want, and you shall have

* Professor of Law, Columbia Law School. B.S., 1948, Univ. of Michigan; M.A., 1949, Yale Univ.; LL.B., 1952, Columbia Univ. Because the first-year course in contracts has traditionally laid heavy emphasis on tcchniques of precise legal analysis, beginning law students have sometimes viewed the subject as divorced from the related disciplines of anthropology, economics, history, philosophy and sociology which they may have encountered im college. That this is not so is demonstrated by a number of scholars who have written of contract law from the perspective of one of those disciplines. In this article I have tried to trace the development of our concept of contract as interpreted in the works of at least some of these scholars. In the thought that the reader may not yet have had a chance to sample the original work, I have, wherever appropriate, quoted the writer's own words to suggest at least some of the flavor of his contribution.

1. W. GoLDING, LORD OF THE FIIES (1954).

2. O. W. Holmes, JR., The Common Law 251 (1881).

3. I. Von Mises, Human Action 143 (rev. ed. 1963). 
this which you want, is the meaning of every such offer; and it is in this manner that we obtain from one another the far greater part of those good offices which we stand in need of. We address ourselves, not to their humanity but to their self-love, and never talk to them of our own necessities but of their advantages. Nobody but a beggar chooses to depend chiefly upon the benevolence of his fellow citizens. ${ }^{4}$

Faith in free enterprise reached its zenith in nineteenth-century America, which placed its trust in the dignity and creativity of the individual and in the social utility of the wealth that he produced. It was through free competition, with maximum opportunity for individual choice and venture, that the economic system could best take advantage of man's "self-love." The goal was a society in which decision making was widely dispersed among its members. In John Kenneth Galbraith's words, "capitalism, as a practical matter rather than a system of theology, is an arrangement for getting a considerable decentralism in economic decision."5 And the law was to serve that goal. As expressed by James Willard Hurst, "the heart of the matter was that law should define and guarantee a wider dispersion of the powers of decision in the community; this it did by committing to private hands legally protected control over the bulk of economic resources."6

The mechanism devised to achieve this goal centers about transactions called "exchanges," in which each party gives something in return for what is given by the other party. Under the market principle, equivalence in these exchanges is determined by the forces of supply and demand arising out of the productivity and the value judgments of individuals. Their terms are arrived at voluntarily by the parties themselves through the process referred to as "bargain" by Adam Smith. Through this process, each party to an exchange seeks to maximize his own economic advantage on terms tolerable to the other party. Because of differences in value judgments and because of the division of labor, it is usually possible for each of them to realize what is for himself a substantial advantage. "When the baker provides the dentist with bread and the dentist relieves the baker's toothache, neither the baker nor the dentist is harmed." 7

Sometimes the bargain is for an immediate exchange of performances by both parties:

Illustration 1. Seller delivers lumber to Buyer. In return, Buyer gives Seller $\$ 5,000$.

Sometimes one of the parties bargains not for the other's present performance, but for his commitment to perform in the future:

4. A. SMrth, An Inguiry into the Nature and Causes of the Wealte of Nations 19 (1811 ed., bk. 1, ch. II).

5. J. K. Galbraith, Amprican Capitalism: The Concept of Countervatimg POWER 200 (rev. ed. 1956).

6. J. W. Hurst, Latv and the Conditions of Freedon in the Nineteenth CenTURX UNITED STATES 8 (1956).

7. L. VoN Mises, sipra note 3 , at 666 . 
Illustration 2. Seller delivers lumber to Buyer. In return, Buyer promises to pay Seller $\$ 5,000$ in 30 days.

And sometimes each party bargains for the other's commitment to perform in the future:

Illustration 3. Seller promises to deliver lumber to Buyer in 30 days. In return, Buyer promises to pay Seller $\$ 5,000$ on delivery of the lumber.

Lawyers analyze such voluntary commitments as those in the last two illustrations in terms of "contract," which Sir Frederick Pollock aptly defined as "a promise or set of promises which the law will enforce." But before the concern of the law with contract must have come the concern of man himself with promise. How and when did that concern begin? We have become so accustomed in our own economic system to securing cooperation to achieve social purposes by the use of promises given in exchanges arrived at through bargain, that it may be difficult even to picture a society unconcerned with bargain, lacking in exchange, or ignorant of promise.

\section{A WORLD Without BargatN}

Adam Smith supposed that "man has almost constant occasion for the help of his brethren" and that "the propensity to truck, barter and exchange one thing for another" was "common to all men."10 Yet according to anthropologists it is possible for a society to exist with little cooperative activity, or to engage in cooperative activity that is not centered about exchange based on bargain.

Most extreme are the "individualistic" societies, ${ }^{11}$ in which self-sufficiency is the rule and cooperation the exception. Probably no people has ever tried to be as fiercely individualistic as Montesquieu's mythical Troglodytes, who resolved "that each individual should attend to his own interests, without troubling his mind about those of his neighbor."12 But there are societies in which the struggle for survival in an inhospitable environment has bred a self-sufficiency which makes cooperation of minor importance. So among the Ammassalik, Greenland Eskimos who depend on the sea for survival, each couple is an essentially self-reliant unit and there is little division of labor or dependence on others. ${ }^{13}$ Tasks that one person can do, such as routine hunting, are usually done alone. Even the longhouse, in which many

8. F. Poliock, Principles of Contract 1 (12th ed. by Winfield 1946).

9. A. Smirt, supra note 4, at 19 (1811 ed., bk. 1, ch. II).

10. Id. at 17,18 .

11. Mead, Interpretative Statement, in Cooperation and Competirion Among PrimtIVE Peoples 458 (M. Mead ed. 1961). Because this article is concerned with the role of promise in the distribution of wealth, the emphasis here is on utilitarian, as opposed to ceremonial, exchanges.

12. Montesouieu, The Persian Letters 23 (Bassorah, ed. 1897).

13. Mirsky, The Eskimo of Greenland, in M. Mead, supra note 11, at 51. 
families assemble by personal preference to share a single room for the winter, is so arranged as to allow for a maximum of individual effort.

While there is a minimum of cooperation, there is also a minimum of competition. Individual wealth consists largely of tools, weapons, boats, tents, clothing and other necessities, made by the owner or his wife. Such inequalities as do exist are generally in quality rather than quantity; a particularly skilled workman will have a better kayak rather than a second one. Surpluses would only hinder their mobile summer life, and even that vital commodity food, obtained primarily from blubbery sea mammals, cannot be accumulated in large quantities because of the absence of any method of preservation. Among the Ammassalik, self-sufficiency has largely dispensed with the need for cooperation.

Most primitive peoples, however, have a heavier dependence on cooperation than do the Ammassalik. Yet not all rely primarily on exchange arrived at through bargain to achieve it. Most of Montesquieu's early Troglodytes perished, we are told, for when those in the highlands had drought, those in the lowlands did not share, and when those in the lowlands had floods, those in the highlands did not share. From the survivors there came a society of latter-day Troglodytes, remarkable for their righteousness and their generosity. ${ }^{14} \mathrm{We}$ are not told whether these qualities permitted them to dispense entirely with bargain and exchange. Yet among "cooperative" societies, such as the Zuni, an agricultural tribe of Indians of New Mexico, a high level of cooperation is achieved largely by encouraging just these qualities and with no substantial emphasis on such reciprocal transactions. ${ }^{15}$ The major focus of Zuni life is religious, and respect comes not through economic betterment but through the observance of ritual and through voluntary cooperation-sharing food with the needy, helping in agricultural labor, and making gifts, particularly in connection with the religious ceremonies. The best known of these is the shalako feast, at which much of a man's wealth may be distributed among the community in order to bring supernatural blessing upon it. Individual wealth, although it may be considerable, is therefore highly transitory and competition for it is discouraged since it is valued only for the immediate material comfort that it will bring. Sharing among one's fellows is said to be widespread among more primitive societies, and particularly so among those that must struggle for survival in a harsh environment, ${ }^{16}$ so that the sharing of good fortune may afford insurance against poor times in an uncertain future.

How have such cooperative societies succeeded in maintaining the al-

14. Montesquieu, supra note 12, at 24-27. Cf. F. N. Robinson, The Complete Works of GeOFFrey CHAUCER 537 (2d ed. 1957): "Sometyme the world was so stedfast and stable that mannes word was obligacioun."

15. Goldman, The Zumi Indians of New Mexico, in M. Mead, supra note 11, at 313. See also R. Benedict, Patterns of Culture 57-129 (1934).

16. M. Gluckanan, Politics, Law and Rituad in Tribai Society 70 (1965). 
truism necessary for a system based so largely on respect for sharing? Montesquieu explained that his latter-day Troglodytes succeeded because they "regarded themselves as one single family."17 Similarly, among peoples such as the Zuni, the individual is born into a closely-knit group in which he has fixed affiliations with kin and clan. " $\mathrm{He}$ does his productive work with the same people with whom he lives, plays, shares good and ill fortune, rears children, celebrates weddings and mourns at funerals," 18 and has few purely economic relationships with other men. It may be that no matter how freely a gift may be given, it carries with it some obligation of an equivalent or an increased return that can be ignored only at the cost of social disapproval and loss of prestige. ${ }^{19}$ Yet "most of the transactions in which men and women are involved, are not specific, single transactions involving the exchange of goods and services between relative strangers. Instead, men and women hold land and other property, and exchange goods and services, as members of a hierarchy of political groups and as kinfolk or affines." ${ }^{20}$ These matters, then, are not determined primarily by voluntary undertakings made as a matter of choice, which give rise to obligations that the law does not otherwise impose. They are largely controlled by what is called "status." In Roscoe Pound's words, "The main characteristics of status are that it is a condition which can not be divested voluntarily, and that rights, duties and liabilities flow from or are annexed to this condition of a person rather than his volition."21 The survival in our own society of this once dominant factor may be seen in the laws of intestate succession, under which wealth is distributed at death according to notions of kinship and affinity.

A society, then, may secure cooperation through sharing based on obligations that are rooted in status instead of through exchanges based on bargains that are rooted in competition. A man works not for personal gain but because according to his fellows and often his religion he ought to do so. And wealth is distributed not through the operation of a competitive market but according to established relations among men. As such a society comes to depend on the land for survival, however, a shortage of land may generate competition over its acquisition. And as a society moves beyond the level of bare subsistence, the accumulation of a surplus may produce competition that focuses on its distribution. Thus the ceremonial feast of the Indians of the

17. MoNTESQUIEU, supra note 12 , at 28 .

18. M. GLUCKMAN, supra note 16 , at 53 .

19. M. Herskovits, Economic Anthropology 155 (1952).

20. M. GluCKMAN, sipra note 16, at 48-49. Von Mises distinguishes between "cooperation by virtue of contract and coordination, and cooperation by virtue of command and subordination or hegemony." L. VoN MISES, supra note 3, at 195.

21. Pound, The End of Law as Developed in Juristic Thonght II, 30 HAnv. L. REv. 200,211 (1917). Some relations that partake of status have their origins, at least in principle, in a voluntary undertaking. This was true of feudalism, which was conceived of as rooted in contract, and it is still true of marriage, which is also said to be derived from contract. 
Northwest Coast, the notorious potlatch, took on a very different aspect from the Zuni shalako. The potlatch, rather than a religious ritual of cooperation, was a means of destructive competition in which rivals could be shamed by a display so lavish and wasteful that they could not meet the obligation to reciprocate. ${ }^{22}$ But the competition is still not centered on bargain. Its goal is not to get the best of a bargain or to accumulate wealth for its own sake, but to gain prestige through its conspicuous distribution. Since the primary objective is not the goods themselves but prestige for the giver, the emphasis is not on equivalence in the value of the objects exchanged, but on equivalence in the adequacy of the gesture. As Max Gluckman has pointed out in relation to the ceremonial exchange of shell valuables among the Trobriand Islanders, what has developed is a relationship

beyond the confines of trade : a man must try to outdo his ... partner in generosity, not try to get the best of a bargain .... This is a virtue in our own civilization, and has been for millennia; but we have had available alternative uses for the use of wealth. There is virtually no choice in a tribe, so that not only are generosity and charity admired, but also there can be no flamboyant living as an alternative. ${ }^{23}$

Contrary to the suppositions of Adam Smith, then, man has succeeded in creating societies that do not rely on bargain as does ours, sometimes because he feels scant need to achieve cooperation, and sometimes because he achieves cooperation largely without exchange based on bargain. Yet all of these societies are primitive. What of more advanced societies? In 1861 Sir Henry Maine assured himself of immortality by asserting that "the movement of the progressive societies has hitherto been a movement from Status to Contract."24 His dictum has stood the test of time, weathered some vigorous criticism, ${ }^{25}$ and found favor among contemporary anthropologists. ${ }^{26}$ As a society begins to become urbanized ${ }^{27}$ and commercialized, the role of promise increases; indeed,

22. M. Gluckman, supra note 16 , at 60,71 ; cf. Goldman, supra note 15 , at 332 .

23. M. GluckMan, supra note 16 , at $49,51-52$.

24. H. MaIne, Ancient Law 170 (1861).

25. See, e.g., M. R. Cohen, Law and the Soctal Order 69-88 (1933); R. Pound, IntERPRETATIONS OF LEgaL HistoRy 53-68 (1923); Graveson, The Movement from Status to Contract, 4 Mod. L. Rev. 261 (1941) ; Pound, supra note 21, at 210-15. The sense in which Maine used this phrase is suggested by his statement that "The movement of progressive societies ... has been distinguished by the gradual dissolution of family dependancy and the growth of individual obligation in its place." Id. 168. Cf. note 21 silpra.

26. See, e.g., M. Gluckman, The Judicial Process Among the Barotse of NorthERN RHODESIA 28 (2d ed. 1967); M. GluckMan, The IDEAs in Barotse JuRIsprudence 171 (1965) ; E. A. Hoebel, Status and Contract in Printitive Laze, in Cross-Culturat UNDERSTANDING 284, 287 ( $F$. S. C. Northrop \& H. Livingston eds. 1964); Redfield, Maine's Ancient Law in the Light of Printitive Societies, 3 WEST. Pol. Q. 574 (1950). See also E. A. Hoeber, The Law of Primitive Man 327-29 (1954).

27. According to Hoebel, the shift "does not really become effective until after the beginning of the urban revolution in full neolithic times. . . For urbanization dissolves the strength of the kinship tie." E. A. Hoeber, The LAw of Prnmitre Man 328-29 (1954). There is a German saying, "Stadthuft macht frei"-_"The city air makes you free." 
there are some striking similarities in the way in which this shift has manifested itself in widely differing societies. We look first to the rise of bargain.

\section{The Rise of Bargain}

Bargain begins with the transaction of barter, in which the parties bargain for the immediate exchange of goods on both sides. Barter does not involve promise, because neither party's performance is deferred so that there is no commitment to perform in the future. It does, however, involve both exchange and bargain. That these two concepts are not universally admired among human kind may be seen from those cooperative societies such as the Zuni, who rely on neither exchange nor bargain. The aversion of primitive peoples to bargain and their tendency to revert to status, even in a commercial setting, is further suggested by two examples from Africa. Where a Barotse, of Northern Rhodesia (now Zambia), barters regularly with an outsider they become "friends" and then perhaps "bloodbrothers," so that what begins as a trading relationship is converted to one of quasi-kinship. ${ }^{28}$ "Thereafter they do not barter item for item, but they are under a general obligation to help each other and to outdo each other in generosity, rather than to seek a good bargain."20 And among the Sebei of Uganda, the parties to a particular type of cattle exchange become "cattle-kin" and "acquire, besides the economic connection, a social relationship that required mutual obligations with respect to their interpersonal behavior."30 Nonetheless, the concepts of bargain and exchange, as manifested in barter, are widespread and even the highly individualistic Ammassalik are reported to "swap" everything from bone darts to wives in much the same informal way as small boys do with picture cards, marbles and knives. $^{31}$

When a society comes to regard a particular form of wealth as a medium of exchange, that is to say as "money" or "currency," it may engage in what we may call "cash" or "present sale," the present exchange of goods for an amount of money that has been bargained for, as in Illustration 1. But although money has been substituted for goods on one side of the transaction, its essence remains the same-there is exchange and bargain, but nothing resembling promise.

Even where the seller is held responsible for the quality of his goods after their delivery to the buyer, promise is not necessarily involved. With respect to the extent of the seller's responsibility, primitive man may be credited with a higher sense of obligation than his more modern counterpart. The Barotse, we are told, see the sale "as involving the highest good faith, like transactions

28. M. GlUCKMAN, supra note 16 , at $14,49$.

29. M. GluckMan, THE Ideas in BARotSE JuRISPRUdence 174 (1965).

30. W. GOLDSCHMIDT, SEBEt LAW 192-93 (1967).

31. Mirsky, supra note 13, at 60-61 (1937). 
among kinsmen," ${ }^{\prime 32}$ and even if an animal dies some time after its sale, the buyer may claim a refund of the price on the ground that there was, in effect, a latent defect..$^{33}$ But the Barotse do not see this as a consequence of a voluntary undertaking by the seller, for "fraud and even innocent mistake are not treated as a breach of agreement but as taking or spoiling a man's property,"34 which in the case of fraud is treated as theft. The germ of promissory liability is not to be found here; it is to be found instead in the rise of credit.

\section{The Rise of CREdit}

Credit comes when a need emerges for an exchange, like that in Illustration 2, in which only one party performs immediately while the other's performance is to take place in the future. Among a people accustomed to reliance on strong ties of kinship and affinity, credit may be slow in developing. Within the circle of kin and affines, tradition may compel sharing rather than exchange ; outside of that circle, the trust in the other party, so necessary for the granting of credit, may be lacking.

In some societies credit never becomes significant. According to Pollock, "The law of contract holds anything but a conspicuous place among the institutions of English law before the Norman Conquest. . . . Anglo-Saxon society barely knew what credit was ...."35 According to Karl Llewellyn and E. Adamson Hoebel, practice among the Cheyenne Indians "shows relatively little of that side of contract which looks to engaging for the future...."36 In other societies its development is limited. Barend ter Haar has explained how the Indonesian concept of magico-religious bond between a man and his land precludes transactions in land except where "all disturbance of the normal equilibrium is avoided by a simultaneous transfer of something equivalent on the part of the receiving unit," ${ }^{\prime 37}$ although other credit transactions flourish. How, then, did credit begin?

One of the most ancient instances of credit arose out of the blood feud. The Germanic and Anglo-Saxon peoples provide a prototype. ${ }^{38}$ Where a

32. M. Gluckaman, The Judictal Process Among the Barotse of Northern RHODESIA 443 (2d ed. 1967). In Gluckman's view, law must stress obligation rather than right in handling disputes among kin in a tribal system in order to preserve already strained relationships. M. GluckMan, THe IdEAS IN BAROTSE JURISPRUdENCE 199 (1965). That the buyer's rights were extensive in our early latv too, see Hamilton, The Ancient Maxim Caveat Emptor, 40 YALE L.J. 1133 (1931).

33. M. Gluckman, The Ideas in Barotse Jurisprudence 177, 189, 195 (1965).

34. Id. at 177 (1965). See also M. Gluckaran, The Judrcial Process Among tere Barotse of NORTHERN RHODESIA 442 (2d ed. 1967).

35. 2 F. Pollock \& F. Maitland, The History of English Law 184 (2d ed. 1899).

36. K. Llewellyn \& E. A. Hoeber, The CheyenNe Way 237 (1941).

37. B. Ter Haar, Adat Law in INdonesta 105 (Eng. Trans. 1948).

38. See generally, 2 W. Holnsworte, A Hrstory of English LAW 83-85 (4th ed. 1936); F. Pollock \& F. Maitland, supra note $35 ; 2$ F. Pollock and F. Mattland, The HISTORY OF ENGLISH LAw 184-89 (2d ed. 1906); Hazeltine, The Formal Contract of Early English Laze, 10 ColuM. L. REv. 608 (1910). The practice of composition to settle 
murderer, in order to buy off the vengeance of his victim's kinsmen, was required to pay a larger wergild than he could immediately raise, he was allowed to pay in instalments by giving security, which was forfeited if he did not pay. Because of the strength of the ties of a family and friendship, primitive man has generally preferred the security of persons to the security of property. ${ }^{39}$ Thus the security at first took the form of hostages, and only later could goods of substantial value be substituted. Max Weber supposed that this giving of security, which enabled the creditor to enforce the debt by self-help, was designed to prevent the even more drastic self-help that might have been required to enforce an unsecured debt. ${ }^{40}$

Gradually the furnishing of hostages was replaced by the furnishing of sureties who assumed personal liability to the creditor, and the pledge of goods of substantial value gave way to the pledge of something of trifling value. This formal procedure, involving a symbolic pledge and the furnishing of sureties, came to be used not only for the settlement of feuds, but also in legal proceedings (an undertaking to appear in court, to furnish proof, to satisfy judgment) and in engagements to marry. So strong was the underlying notion of forfeiture, that originally it was not the debtor but the hostage or surety who was regarded as liable to the creditor, with the debtor liable in turn to the hostage or surety. Only when the debtor was allowed to be his own hostage or surety did the liability come to be seen as one from the debtor directly to the creditor. The debtor might then furnish no sureties, and the traditional formalities began to be supplanted by others, including the spoken pledge of faith and the proffering of the right hand. In Germanic custom it was essential that the formalities be not only capable of being seen and heard, but be actually seen and heard by witnesses. These formalities were not, however, regarded as creating a fresh obligation by virtue of promise, but rather as confirming a liability which preceded them. The thread of development of these formalities in Roman and early English law will be picked up shortly. But first we must see how credit came to be used together with exchange arrived at by way of bargain in a commercial setting. This step came with the transaction of loan.

a grievance appears to be widespread in primitive societies. See, e.g. E. A. HoEdeL, THE Political Organization and Law of the Comanche Indians 125 (1940).

To facilitate settlement, the state published a schedule of payments for various injuries. An example from the laws of Ethelbert, of about 600 A.D., reads: "For each of the four front teeth, VI shillings; for each tooth which stands next to them, IV shillings, for that which stands next to that, III shillings ; and then afterwards, for each a shilling." Quoted in C. McCoRMrck, HANDBook on the LAW of DAMAGES 22 (1935).

39. The Romans, particularly in early times, are said to have preferred surety to pledge, partly because of the solidarity of social groups. W. W. BUCKLAND, ROMAN LAW AND COMMON LAW: A CoMPaRISON IN OUTL1NE 324-25 (2d ed. by F. H. Lawson 1965). 40. M. WEBER, ON LAW IN ECONOMY AND SocIETy 116 (Rheinstein ed. 1954). It is said that "originally hostages were delivered bound, and the whole terminology of the law of obligations preserves the memory of this starting point." Pound, The Role of the Will in Laz, 68 HARV. L. REv. 1, 2 (1954). 
Because of those same ties of kinship and affinity that generally impeded the rise of credit, the loan, if it does arise, often appears first as a secured loan, with a pattern of security very similar to that used for the wergild. Paul Bohannan found the unsecured loan to be rare among the Tiv of Northern Nigeria. Because of the tradition of sharing, one does not lend to close kinsmen, "one gives to them"; and because of lack of trust, one does not lend to others, "one pawns to them." 41 Furthermore, the commercial incentive to make the loan is often lacking, since some primitive peoples look down on the taking of interest. ${ }^{42}$ Nevertheless, when special needs for credit occur, the loan arises to meet them. Max Gluckman tells how in Africa a family may require a loan in order to pay the bride-piece for one of its members, and in order to meet such emergencies land is pledged or an individual is pawned into "debt-slavery," being permitted to work off the debt. ${ }^{43}$ The loan may be for use, and contemplate the return of the goods loaned, perhaps with an additional payment for compensation. Or it may be for consumption, and contemplate repayment by other goods, perhaps of greater value.

From the loan transaction, it is but a short step to the credit-barter or the credit-sale, in which, as in Illustration 2, performance on one side is deferred, one party merely promising while the other actually performs. So among the Tswana of Botswana, Isaac Shapera reports, a man might take an ox for slaughter, or rafters or thatch for a hut, or some other commodity, promising to replace it or to pay an equivalent price. ${ }^{44}$ In ancient times, the Assyrians and Babylonians used two tablets to represent the credit-sale, one for the sale and the other for the loan that made the sale possible. "Lacking both money and writing, the Barotse had not achieved this sophistication, though in discussing cases arising out of this kind of transaction they speak of it as they do of a straightforward loan."45

From the delivery of goods on credit, it is but another step to the furnishing of services on credit. Exchanges involving services come when specialization of function in a society generates a demand for services. And since services usually take time for their performance, while payment can be made instantaneously, an exchange of services for payment cannot ordinarily be made simultaneously. One party must look to the future and rely on the other's credit.

41. P. Bohannan, Justice and Judgment Among the Tiv 107 (1957).

42. I. Schapera, A Handbook of Tswana Law and Custom 245 (1938). Among the Kapauku Papuans a promise to pay interest gave rise to a moral obligation, but not a legal one. L. Posprsm, Kapauku Papuans and Their LAW 129-30 (1958). And, of course, the early Christian Church disapproved of interest. But for examples of high interest rates among some primitive peoples, see M. HERSKOVITS, ECONOMIC ANTHROPOLogy 228-29 (1952); E. S. Haydon, Law aNd Justice in Buganda 237 (1960).

43. M. GLUCKMAN, supra note 16 , at 74 .

44. I. Schapera, supra note 42 , at 242.

45. M. Giuckman, The Ideas in Barotse Jurisprudence 178 (1965). 
Illustration 4. Owner promises to pay Builder $\$ 10,000$ if Builder does specified work on his house. Builder does the work.

Illustration 5. Builder promises to do specified work on Owner's house if Owner pays him $\$ 10,000$. Owner pays him $\$ 10,000$.

Among the earliest specialties to give rise to a demand for services is "doctoring" or witchcraft by medicine men, shamen and sorcerers." A more important sort of service, at least among pastoral peoples, is caring for animals. Bohannan recounts how the Tiv have perfected the practice of "releasing" their goats to caretakers. To have them at home exposes thein to the claims of his kinsmen, while by widespread releasing one can say with truth that all the goats in one's compound belong to someone else. The caretaker receives one kid in three as his compensation. ${ }^{47}$ Other societies, for less devious reasons, have developed comparable practices to provide for the care of livestock. Among the Tswana, for example, a chief may entrust his cattle to the care of the poor or of prominent commoners and their followers. Similarly, one man may hire another to do special work, such as building or roofing a hut, clearing a field or digging a well.48

But the idea of loan still left man short of a conception of promise, for the duty to which the loan gives rise is not generally regarded by primitive societies as arising out of the debtor's word. To the primitive mind the debt is recoverable, not because the debtor has promised to repay it, but because he has received goods which, although they are in his custody, are still regarded as belonging to the creditor. Under this view, a breach by the debtor is not a failure to perform a promise but a wrong with respect to property. Frederick William Maitland spoke of "the vast gulf which to our minds divide the 'Give me what I own' and 'Give me what I am owed,' "40 and according to Holmes, debts were not originally conceived of "as raised by a promise," but "were a 'duty' springing from the defendant's receipt of property." $" 50$ Bohannan reports that among the Tiv the relationship between pledgor and pledgee is not seen in terms of promise but in terms of debt. ${ }^{61}$ Gluckman confirms that this is equally true among the Barotse, whose concentration "on the material elements inyolved in contract . . . leads them to think of all contracts as involving debts...., and of their main remedy in terms of restitu-

46. There is a disctussion of this type of transaction in E. A. HoEbEL, supra note 38, at 125-28. See also I. Schapera, sulpra note 42, at 256; I. Schapera, THE BANTUSpeaking TrIBes of Soute Africa 201-02 (1956). Among the earliest cases of contracts for services in English law is one in 1360 arising out of a suit by a surgeon for curing an arm. 2 W. HoldswortH, supra mote 38, at 388 n.5 (4th ed. 1936).

47. P. BohanNaN, supra note 41 , at 21 .

48. I. Schapera, supra note 46, at 248,254 . See also W. Goldschand, supra note 30 , at 207-14.

49. F. W. Mattrand, The Forms of action at Common Law 38 (1936).

50. O. W. Holmes, JR., supra note 2 , at 264 .

51. P. Borannan, supra note 41 , at $111-12$. 
tion." "52 Indeed, according to Pollock, in English law "[ $t]$ he creditor sued to recover money for centuries after the Norman Conquest, in exactly the same form which he would have used to demand possession of land .... [T] he foundation of the plaintiff's right was not bargain or promise, but the unjust detention by the defendant of the plaintiff's money or goods." displays the same conception of the transaction when he refers to "his money" in the bank, rather than the obligation that the bank owes him.

The same view carries over to transactions related to the loan, such as those in Illustrations 2, 4, and 5, which are also seen only as giving rise to debts, not to promises. Gluckman says that the Barotse, in discussing cases arising out of credit-barter, "speak of it as they do of a straightforward loan: it establishes a debt." 54 Similarly, where services are involved, "even when servants sue their masters for their wages [the Barotse] tend to argue not in terms of the agreement to pay them wages but in terms of what has accrued from their work, as if they have proprietary rights in this product, which the employer has filched."

Gluckman gives some illuminating examples of the consequences of this view of debt among the Barotse. If a man orders an article, such as a dugout, to be made for him, he has an enforceable claim only if he has paid for it: if the article has been made, he can recover it, and if it has not been made, he can recover what he has paid. But if he has paid nothing, he has no remedy. Similarly, if a man arranges to transfer goods in exchange for other goods, he can claim the other goods if he has performed his part of the bargain. But if he has not transferred his goods to the other party, he has no claim. There must, in short, be some transfer of goods in order to create rights and obligations, ${ }^{56}$ a requirement that $\mathrm{Max}$ Weber maintained was generally characteristic of primitive societies in which legal thought was concerned only with wrongs, such as misdeeds against goods, and not with intangible phenomena like simple promises. ${ }^{57}$ Gluckman notes Maine's statement that "a Contract was long regarded as an incomplete Conveyance."58

Since under this view credit is not seen as involving promise, there is still no room for the exchange of promise for promise, as in Illustration 3 , in which performance on both sides is deferred and there is no immediate deliverance of property or performance of services. Conceptually, the sanctioning of a

52. M. Gluckman, The Judicial Process Among the Barotse 442 (2d ed. 1967).

53. Pollock, Contract, in 7 Encyclopedia BRITANnICA 35, 36 (11th ed. 1910).

54. M. Gluckaran, The IdeAs in Barotse Jurisprudence 178 (1965).

55. Id. at 194.

56. Id. at 180-82. Goldschmidt says that among the Sebei, "a man cannot take action against another for withdrawal from a promise to perform provided that restitution of the original consideration is made. W. GoLDSCHMIDT, supra note 30 , at 188 .

57. M. WeBER, supra note 40 , at 120 .

58. H. MAINE, supra note 24, at 321, quoted in M. GluCKMAN, supra note 54, at 183. 
purely consensual transaction consisting merely of the exchange of simple promises requires a level of abstraction greater than that required for the recognition of either a formal acknowledgment of liability coupled with perceptible ceremony, or a liability based on a debt arising out of a discernable return performance. And practically, unless there is a market on which prices fluctuate, there is little economic need for parties to arrange for such an exchange to take place in the future at a price fixed at present. If, in Illustration 3, Seller should fail to deliver the lumber at the end of 30 days, Buyer will be obliged to buy substitute lumber. But if he can still do so at the contract price of $\$ 5,000$, his loss is only the inconvenience of arranging the substitute transaction and the economic importance of the agreement to him is minimal. If, however, the price of lumber has risen so that he must pay, say, $\$ 5,500$ at the later date, his loss will be increased by $\$ 500$ and the economic importance of the agreement to him will be at least that amount. Buyer's expectation is that the transaction will protect him against such an adverse change in the market. Because of the absence of such a market it is not surprising that, according to Gluckman, such transactions in which there has been no performance on either side are not recognized in Barotse jurisprudence, and that this appears to be true of Africa as a whole ${ }^{59}$ and of primitive societies in general. ${ }^{60}$

Credit has developed, but the rise of promise considered as promise is yet to come.

\section{The Rise of Promise}

The notion that a promise itself gives rise to a duty was an achievement of Roman law. It came, however, through the development of a series of exceptions rather than through the establishment of a general principle of enforceability of promises. ${ }^{61}$ The maxim evolved in Roman law that a naked pact (mudum pactum) did not beget an action. Although an agreement might have moral efficacy, it was not legally enforceable unless it fell within a limited number of categories that the law came to treat as exceptions to this general rule. The story of the rise of promise in Roman law is the account of the growth of these categories.

One of these categories, established in very early times, turned on formalities. A party could bind himself by a promise known as a "stipulation" (stipulatio) if he observed the prescribed form of question and answer. The

59. M. Gluckman, The Ideas In Barotse Jurisprudence 179-82 (1965). But sec E. S. HAYDon, supra note 42 , at 232 for an example of a bilateral contract for the sale of goods said to be binding upon a mere handshake.

60. A. S. Diamond, Primitive Law 401 (1950); W. Seagle, The Quest for Law 256-57 (1941).

61. On contracts in Roman law, see generally F. H. LAwson, A Common LaWYER Looks at THE CIVIL LAW 113-37 (1955); W. W. BuckLAND, A Text-Book of RoMaN LAW FROM AUgustus ro JUSTINIAN chs. 10, 11 (2d ed. 1932). 
terms of the promise were framed not by the promisor but by the promisee, who was then required to put them to the promisor in his presence as a solemn question, typically asking "Spondesne?" ("Do you undertake?") to which the promisor was to respond "Spondeo." ("I undertake"). Although the historical origins of the stipulation are uncertain, the most probable view is that it arose in the procedural obligations undertaken in legal proceedings which, as we have seen, are among the earliest forms of promise to have arisen in many primitive societies. ${ }^{62}$ Although the participation of both parties was needed, only one party was bound, and for this reason the stipulation was not by nature well suited to bargains that resulted in an exchange of promises, as in Illustration 3, where a pair of reciprocal stipulations would have been required.

Nor could such transactions be brought within the category of "real" contracts, another of the earliest types of enforceable agreements to be recognized in Roman law. Real contracts were those in which the handing over of the subject matter made the promise binding. They were of four types: the loan for consumption (the oldest of the four), the loan for use, the gratuitous deposit, and the pledge. But the responsibility of the recipient under each of these real contracts could be as easily viewed as arising out of debt as out of promise. And since the validity of the contract depended upon delivery by one of the parties, it was not adaptable to transactions, such as that in Illustration 3 , where there was a simple exchange of promises with no performance on either side.

To meet the need for a legal basis for such exchanges there evolved the "consensual" contracts, in which the mere agreement of the parties was binding. They differed from the stipulation in that they lacked its formalities, for no particular form of words was required, and they could even be made by correspondence. They differed from the real contracts in that agreement alone without delivery sufficed to make them binding on both parties. But in keeping with the pattern of evolution through the growth of exceptions, they were limited to four types of commercially important contracts: sale, hire, partnership, and mandate. They did, however, include the specific transaction of sale in Illustration 3. As F. H. Lawson put it:

It is as if the Roman jurists of about 100 B.C. had said "Go where you will, you will find that almost everything [that men do in business] can be reduced to four processes: (1) shifting goods permanently from one man's estate to another for a money price; (2) placing one person's property or services temporarily at the disposal of another for a consideration usually in money; (3) the pooling of property, skill, or experience by several persons for a common purpose; and (4) the gratuitous performance of a task by one person on

62. W. W. BuckLAND, sipra note 61 , at 434 . Even today, carefully worded clauses in formal agreements are sometimes termed "stipulations" in this country. 
the instructions of another. Moreover the secure and rapid flow of business requires that we should think of the relations implied in these processes as commencing not from acts but from promises to act." ${ }^{\text {" }}$

In contrast to the stipulation, in which the promisor was held only to the obligation expressed in the question that had been put to him, the consensual contracts were regarded as imposing upon each party an obligation to perform in "good faith." To implement this general obligation, the Roman jurists formulated more precise sets of obligations that were then imposed on the parties to the various consensual contracts. But with this accomplishment Roman jurists contented themselves and did not develop a general basis for the enforcement of promises.

The furthest that the Romans went was the recognition, by the time of Justinian in the sixth century, of the "innominate" contracts. These were agreements under which one party promised to give or do something in exchange for a similar promise by the other party. They were severely limited, however, because they were binding only when one of the parties had completed performance, and until that event either party could escape liability. Nevertheless, they differed from both the real and consensual contracts in that they were not confined to specified classes of transactions, and were hence "innominate." Moreover, they differed from the real contracts in that the enforceability of the promise turned on something by way of performance given in exchange and called a quid pro quo. But neither the innominate nor any of the other enforceable contracts resulted in the development of a general basis for the enforcement of promises that would include a promise made in exchange for another promise, where there had been no formalities and no return performance.

\section{The Rise of a General Basis of Enforcement}

The human mind is slow to generalize, and Roman law, having inherited the tendency of primitive societies to view each type of transaction as a distinct complex of rights, never fully rid itself of this proclivity. The development of a general basis for the enforcement of promises-a general theory of contract, if you will-was therefore left to the great modern legal systeins that arose in Europe during the Middle Ages; the common law system that grew up in England and the civil law systems that emerged on the Continent. ${ }^{04}$

63. F. H. LAwsoN, supra note 61 , at 127 .

64. For a brief discussion of its development in the civil law systems on the Continent, see F. H. LAwson, A Common LawYer Looks AT THE Crvil Law ch. 4 (1955). The following discussion of the common law development is based on C. H. S. FIFoot, History AND Sources of the CoMmon LaW: TORT AND Contract pt. 2 (1949); 2 W. Holdsworth, A Hitstory of ENGLISH LAW 82-87 (4th ed. 1936) ; 3 W. Holdswortir, A History of English LaW ch. 3 (4th ed. 1935); 2 F. Pollock \& F. Maitrand, Tine HISTORY of ENGLISH LAW ch. 5 (2d ed. 1899); Ames, Parol Contracts Prior to 
Curiously, the common law began at a less advanced stage than that attained by Roman law. Roman concepts of contract were known in England in the twelfth and thirteenth centuries. But although they inspired the comparable evolution of a general theory of contract in the civil law systems of the Continent, they exercised no significant influence on the common law. The common law was thus able to chart its own peculiar course in the direction of a general basis for the enforcement of promises. As explained by Pollock, "Ideas assumed as fundamental by this branch of law in modern times and so familiar to modern lawyers as apparently to need no explanation had perished in the general breaking up of the Roman system, and had to be painfully reconstructed in the middle ages." $" 65$

No legal system devised by man has even been reckless enough to make all promises enforceable. In Morris Cohen's words:

It is indeed very doubtful whether there are many who would prefer to live in an entirely rigid world in which one would be obliged to keep all one's promises instead of the present more viable system, in which a vaguely fair proportion is sufficient. Many of us indeed would shudder at the idea of being bound by every promise, no matter how foolish, without any chance of letting increased wisdom undo past foolishness. Certainly, some freedom to change one's mind is necessary for free intercourse between those who lack omniscience. ${ }^{66}$

But in framing a general theory for the enforcement of promises, this goal can be approached from two extremes. One can begin with the premise that promises are generally enforceable and then create exceptions for promises which it is thought undesirable to enforce. Or one can begin with the premise that promises are generally unenforceable and then create exceptions for promises which it is thought desirable to enforce. In the centuries following the Conquest in England, both views had substantial support.

The former view, which laid emphasis on the force of the promise itself, was held by the canon law, the law merchant, and equity. As for the canon law, already in the twelfth century the Church allowed a Christian to pawn his salvation, regarded a promise made with a pledge of faith as enforceable and its breach as a mortal sin, and was moving toward the view that even a simple promise, without a pledge of faith, was sacred and therefore enforceable. As for the law merchant, the fair and market courts entertained numerous actions, as commerce required, upon simple promises made by merchants. And as for equity, the Chancellor held the view that the law of man must accord with the law of God and, in his own words in the fifteenth century,

Assumpsit, 8 HARv. L. REv. 252 (1894); Ames, The History of Assumpsit, 2 HaRv. L. REV. 1, 53 (1888); Hazeltine, The Formal Contract of Early English Law, 10 CoLUM. L. Rev. 608 (1910).

65. 2 F. Pollock \& F. MatTland, sipra note 64, at 184 .

66. Cohen, The Basis of Contract, 46 HARv. L. REv. 553, 573 (1932). 
because a man was "damaged by the non-performance of the promise, he shall have a remedy."

The view that promises are not generally enforceable, which started from the premise of Roman law that a mere agreement did not beget an action, was held by the common law. Its choice was scarcely surprising. It accorded well with the procedural niceties of common law courts, where recovery was not to be had unless the claim could be fitted within one of the established forms of action; and it suited the status-oriented society of the Middle Ages, which was anything but conducive to the flowering of promise. Furthermore, there was no great pressure for enforceability as contracts were not a significant part of the business of the common law courts. At the end of the twelfth century Ranulf de Glanville apologized for the scant treatment of the subject in his treatise on English common law with the remark that "it is not the custom of the court of the lord King to protect private agreements, nor does it even concern itself with such contracts as can be considered to be like private agreements." 68

Nonetheless, it was the common law view that was ultimately to prevail. It achieved its success less on its intrinsic merits than as a by-product of the victories of the common law courts in their jurisdictional struggles with their competitors. As for the canon law, through the Constitutions of Clarendon of 1164 , born of the quarrel between Henry II and Thomas á Becket, the common law courts were able to deprive the Church of its jurisdiction over breach of faith in temporal matters and to snuff out the attempts of the ecclesiastical courts to implement their view that promises were in themselves sacred. As for the law merchant, by the sixteenth century the common law courts had begun their successful attempt to wrest jurisdiction from the commercial courts and to stifle the view that simple promises made in commerce should be enforced. ${ }^{99}$ And as for equity, although it alone among the three competing jurisdictions was to survive the jurisdictional ambitions of the common law courts, the Chancellor hesitated to intervene unless the common law was wanting. It is a tribute to the ingenuity and flexibility of the common law judges that they succeeded in moving fast enough to stay the Chancellor's hand so that credit for the development of the general basis for the enforcement of promises that we know today was theirs and theirs alone. The challenge that faced them was to work within the framework of the forms of action, first

67. Anon. (1468) Y. B. Pasch. 8 Edw. 4 at f. 4, pl. 11, C. H. S. Fifoot, sulpra note 64 , at 304 .

68. R. de Glanville, The Treatise on the Laws and Customs of the Realas of ENGLAND bk. 10, ch. 18 (G. D. G. Hall ed. 1965). See also bk. 10, ch. 8 .

69. Lord Mansfield attempted to revive this view in Pillans v. Van Mierop, 97 Eng. Rep. 1035,1038 (K.B. 1765), where he said: "A nudum pactum does not exist, in the usage and law of merchants. ... In commercial cases among merchants, the want of consideration is not an objection." But the House of Lords repudiated it in Rann $v$. Hughes, 101 Eng. 'Rep. 1014n (H.L. 1778). 
to develop exceptions as the Romans had done, and then to so fashion these exceptions as ultimately to achieve what the Romans had never achieved-a general theory of contract. This challenge was met by the common law courts in the course of the fifteenth and sixteenth centuries. "Surely," wrote James Barr Ames, "it would be hard to find a better illustration of the flexibility and power of self-development of the Common Law."70 The achievement was all the more remarkable in view of the fact that when this development began, the English law of contracts was little more advanced than that of many primitive societies. How was it brought about?

One possible vehicle for this development might have been the formal acknowledgment of liability that had early been the basis for the Roman stipulation and that had its ancient origins in the Germanic and Anglo-Saxon blood feuds. Out of this there grew up in England the common law action of covenant, which appeared near the end of the twelfth century, and which, had the trend been toward relaxation of formalities, might have served as the basis of a general contractual remedy. This possibility was foreclosed, however, when by the end of the following century the formality of the action was increased by the requirement that it be predicated on a writing under seal. With this turn of events, any hope that covenant might serve as a general ground for contractual liability vanished, since a sealed writing was little better suited to an informal exchange of promises than the Roman stipulation had been.

Another possible avenue of evolution might have been through the concept of loan, familiar to most primitive societies. Out of this, by the end of the twelfth century, had grown the action of debt, under which "the defendant was conceived of as having in his possession something belonging to the plaintiff which he might not rightfully keep, but ought to surrender.'"71 $\mathrm{He}$ was liable not because he had promised but because he had received a benefit which he should be required to disgorge. Following this rationale, the action of debt was broadened to allow recovery for personal services, where performance of the services was treated as analogous to delivery of a chattel. Finally, the action came to be recognized as available to anyone who had conferred a substantial benefl-called a quid pro quo in imitation of the Romans-against the one who had received it.

Illustration 6. Builder promises to do specified work on Owner's house in return for which Owner pays him $\$ 10,000$. After receiving the payment, Builder fails to do the work.

70. Ames, The History of Assumpsit, 2 HARv. L. REv. 53, 69 (1888). On equitable jurisdiction in contract during this period, see W. Barbour, The History of Contract in Early English Equity, in 4 OXFord Studies IN SOCIAL aND Legal History 150-68 (P. Vinogradoff ed. 1914).

71. Ames, Parol Contracts Prior to Assumpsit, 8 HARv. L. Rev. 252, 260 (1894) The actions of detinue (which was originally part of debt until it emerged from this earlier composite form in the course of the thirteenth century) and of account will not be discussed here. Like debt, they too required performance by one of the parties. 
In this situation the action of debt was adequate to allow Owner to recover from Builder. Since the promisor had unjustly received a benefit and the promisee had unjustly sustained a detriment, usually identical with the benefit, the restlt was both to prevent the unjust enrichment of the promisor and redress the detriment suffered by the promisee. Lon Fuller and William Perdue have styled the interest that is here protected the "restitution interest."'72 But since it was clear that the benefit must have been actually conferred, and that a mere promise to confer it would not suffice, it was no better suited than the innominate contracts of Roman law to the enforcement of a mere exchange of promises, such as that in Illustration 3, under which there had been no performance. Moreover, it carried with it the further inconvenience that the defendant might, in the case of a simple debt not under seal, "wage his law," that is, undertake to deny the debt by an oath with oathhelpers. How was the common law to break out of this mold ?73

The common law courts found the answer in the law of torts. They had already recognized that liability in tort arose when a person undertook (assumpsit) to perform a duty and then performed it in such a way as to cause harm. Stuit could be brought on the special variety of trespass on the case that came to be known as assumpsit. At the beginning of the fifteenth century it was available only where there had been misfeasance in performance of the under" taking. This example was given in 1436: "If a carpenter makes a covenant with me to make me a house good and strong and of a certain form, and he makes me a house which is weak and bad and of another form, I shall have an action of trespass on my case." 74 In such cases of misfeasance it was not hard to justify liability in tort. But might not the same remedy lie when there had merely been nonfeasance, a failure to perform the undertaking? At first the answer was no. In 1410 it was said: "Certainly it would lie [if the carpenter had built the house badly], because he would then answer for the wrong which he had done, but when a man makes a covenant and does nothing under that covenant, how can you have an action against him without a deed ?"75

Nevertheless, by the second half of the fifteenth century there was a growing tendency among the common law judges to make the first major extension in the action of assumpsit by enforcing such promises even where there had

72. Fuller and Perdue, The Reliance Interest in Contract Danages: 1, 46 YALE L.J. 52,53 (1936). The amount of recovery in debt at common law was not, however, limited to the value of the benefit conferred, but could be any definite amount of money or goods that the debtor had promised to pay. Ames, Parol Contracts Prior to Assimmpsit, 8 Hanv. L. Rev. 252, 260 (1894). See also T. Plucknetr, A Concise History of the Cominon LAw 363 n.1 (5th ed. 1956).

73. The common law was able to surmount this difficulty, within the confines of the action in debt, to the limited extent that a seller of goods was, by the latter part of the fifteenth century, allowed to sue in debt although he had only promised to deliver and no delivery had taken place. See $3 \mathrm{~W}$. HoLDsWoRTH, silpra note 64, at 355-57; Ames, Parol Contracts Prior to Assumpsit, 8 HARv. L. REv. 252, 258-59 (1894).

74. Y.B. $14 \mathrm{Hy}$. VI, at $18,3 \mathrm{~W}$. Holdsworth, supra note 38 , at 430.

75. Y.B. Mich. 11 Hy. IV, pl. 60, 3 W. Holdsworre, supra note 38, at 433-34. 
been only nonfeasance. This inclination was encouraged by the fear that if they did not do so the Chancellor would. But some limits had to be placed on what promises would be enforced, for the judges were not about to allow "that one shall have trespass for any breach of covenant in the world."76 The courts were therefore forced to find a test to distinguish instances where nonfeasance was actionable from those where it was not. Since the misfeasance cases that had originally given rise to the action in assumpsit were characterized by a detriment incurred by the promisee in reliance on the promise, it was natural to formulate an analogous test and to allow enforcement where the promisee had changed his position on the faith of the promise, and had been consequently damaged by its nonperformance.

Illustration 7. Builder promises to do specified work on Owner's house in return for which Owner promises to pay $\$ 10,000$ on its completion. In reliance on Builder's promise, Owner rents another house and moves into it to permit Builder to do the work. Builder fails to do the work.

Here the law's justification in protecting Owner is based on the detriment sustained by him through his reliance on the promise, not on any benefit received by Builder, and is less clear than in Illustration 6. To the extent that the promisee has incurred expenditures in preparing for performance, or has suffered loss by foregoing other opportunities, without conferring any benefit upon the promisor, the broken promise has resulted in a waste that cannot be undone by a simple reversal as in the case of recognition of the restitution interest. Nevertheless, in a society that depends upon promises for cooperation, there is justification in protecting those who rely on promises by placing the cost of the waste occasioned by broken promises on those that break them through requiring the party in breach to compensate the injured party in an amount sufficient to put him in as good a position as he would have been in had the promise never been made. This interest is called the "reliance interest" by Fuller and Perdue. ${ }^{77}$ But since some action in reliance on the promise was required, this first major extension of the action of assumpsit did not make a mere exchange of promises, without more, enforceable.

As the sixteenth century drew to a close, however, the common law courts, conscious of the expanding jurisdiction of Chancery and anxious to preserve their own powers, made a second major extension of the action of assumpsit. Thus it was held that a party who had given only a promise in

76. Y.B. Hil. 3 Hy. VI, pl. 33, 3 W. Holdsworth, supra note 38 at 435 .

77. Fuller and Perdue, supra note 72, at 54. "[I]n the early stages of its growth the action of assumpsit was clearly dominated by the reliance interest, so much so that Ames assumed, even in the absence of cases in point, that recovery in assumpsit must originally have been limited to compensation for change of position." Id. at 68. But see Washington, Dantages in Contract at Common Law, 47 L.Q. REv. 345, $371-79$ (1959). 
exchange for the other's promise had, nonetheless, suffered a detriment by having his freedom of action fettered, since he was in turn bound by his own promise.

Illustration 8. Builder promises to do specified work on Owner's house in return for which Owner promises to pay $\$ 10,000$ on completion. Before Owner has done anything in reliance on Builder's promise, Builder repudiates the bargain.

The reasoning was, of course, circular, since the detriment to the promisee, in this case the Owner, assumed that he was bound by his own promise, for which only a promise had in turn been given. Nevertheless, by the end of the sixteenth century the common law courts were enforcing exchanges of promise, as in Illustration 8 , where nothing had been done on either side. ${ }^{78}$

Since the promisee had neither conferred a benefit upon the promisor nor incurred any detriment in reliance on the promisor's promise, it may seem questionable that the law was justified in protecting the promisee by requiring the promisor to compensate him for his disappointed expectations-that is to say, for the advantages that he would have received had the promise been performed. Pound maintained that:

In a developed economic order the claim to promised advantages is one of the most important of the individual interests that press for recognition. If it is a task of the legal order to secure reasonable individual expectations so far as they may be harmonized with the least friction and waste, in an economic order those arising from promises have a chief place. ... It is a presupposition of the whole economic order that promises will be kept.... The social order rests upon stability and predictability of conduct of which keeping promises is a large item. ${ }^{79}$

This interest of the promisee is called the "expectation interest" by Fuller and Perdue. ${ }^{80}$

And yet why, merely because the parties have exchanged promises, should the law protect one party's ephemeral expectation where the other attempts to repudiate before the former has done anything in reliance on the promise? It is doubtful that the promisee's sense of grievance and his temptation to redress the wrong himself are strong enough to warrant enforcement of the promise to keep the peace. True, our society enjoys a sophisticated market economy, in which prices fluctuate and the expectation created by a promise to perform in the future is something of value. But this argument is also circular since such a promise is something of value precisely because the

78. Strangborough v. Warner, 74 Eng. Rep. 686 (Q.B. 1588).

79. Pound, Individual Interests of Substance-Promised Advantages, 59 HARv. L. REv. 1, 1-2 (1945).

80. Fuller and Perdue, supra note 72, at 54. The expectation interest in the case of a sealed, as opposed to a simple, promise was of course enforced in the action of covenant at a much earlier date. 
law does enforce it. A more convincing explanation is that offered by Fuller and Perdue, which is, in essence, that protection of the expectation interest is justified because it is the most effective way of protecting the reliance interest.

Agreements can accomplish little, either for their makers or for society, unless they are made the basis for action. When business agreements are not only made but are also acted on . . . economic activity is generally stimulated. These advantages would be threatened by any rule which limited legal protection to the reliance interest. Such a rule would in practice tend to discourage reliance. The difficulties in proving reliance [especially when it consists in foregoing other opportunities to enter contracts] and subjecting it to pecuniary measurement are such that the business man knowing, or sensing, that these obstacles stood in the way of judicial relief would hesitate to rely on a promise in any case where the legal sanction was of significance to him. To encourage reliance we must therefore dispense with its proof. For this reason it has heen found wise to make recovery on a promise independent of reliance, both in the sense that in some cases the promise is enforced though not relied on (as in the bilateral business agreement) and in the sense that recovery is not limited to the detriment incurred in reliance. ${ }^{81}$

They recognize that this has "a quasi-criminal aspect, its purpose being not so much to compensate the promisee as to penalize breach of promise by the promisor," 82 but contend that this is warranted at least with respect to some promises. On this ground the extension of the action of assumpsit to include the mere exchange of promises can be justified.

The action was to experience yet one more important extension. The procedure in actions of assumpsit, in which the plaintiff was entitled to a jury trial, was more favored by creditors than that in actions of debt, in which the defendant could resort to wager of law. The next step in the common law's development of the law of contract was to permit assumpsit to supplant debt. By the middle of the sixteenth century, it had been recognized that an action in assumpsit could be brought against a defendant who, being already indebted (indebitatus), expressly undertook (assumpsit) to pay a particular sum. This action was called one in "indebitatus assumpsit," to distingnish it from the older "special assumpsit." Toward the end of the century, it began. to be held that a debt alone, without a subsequent express promise, would support such an action. The final triumph of this view came at the beginning of the seventeenth century in Slade's case in which, on a jury finding that

81. Fuller and Perdue, supra note 72, at 61-62. As the authors point out, "the force of the argument will depend entirely upon the existing economic environment. It would be most forceful in a hypothetical society in which all values were available on the market and where all markets were 'perfect' in the economic sense. In such a society there would be no difference between the reliance interest and the expectation interest. The plaintiff's loss in foregoing to enter another contract would be identical with the expectation value of the contract he did make. The argument that granting the value of the expectancy merely compensates for that loss, loses force to the extent that actual conditions depart from those of such a hypothetical society." Id. at 62 .

82. Id. at 61 . 
"there was no other promise or assumption, but only the said bargain," the judges of England resolved "that every contract executory imports in itself an assumpsit." 84 The creditor was at last assured of the benefits of jury trial in place of wager of law and was freed of the technicalities of pleading in debt.

Over the course of the fifteenth and sixteenth centuries the common law courts had succeeded in evolving a general basis for the enforceability of promises through the action of assumpsit. During the sixteenth century the word "consideration," which had earlier been used without technical significance, came to be used as a word of art to express the sum of the conditions necessary for an action in assumpsit to lie. It was therefore a tautology that a promise, if not under seal, was enforceable only where there was "consideration," for this was to say no more than that it was enforceable only under those circumstances in which the action of assumpsit was allowed. In this fashion, however, the word "consideration" came to be applied to the test of enforceability of a simple promise and to be used to distinguish those promises that in the eyes of the common law were of sufficient significance to society to justify the legal sanctions of assumpsit for their enforcement.

It was, to be sure, neither a simple nor a logical test. Bound up in it were several elements. Most important, from the quid pro quo of debt by way of indebitatus assumpsit, had come the idea that there must have been an exchange arrived at by way of bargain. This precept has remained at the core of the concept of consideration down to today. ${ }^{85}$ From the same source had come the notion that there must be a benefit to the promisor, while from the reliance of special assumpsit came the notion that there must be a detriment to the promisee-both notions that have proved less durable than those of exchange and bargain. The requirement of an exchange accorded well with what has been called the "theory of equivalents," under which an abstract promise is enforceable only when supported by an equivalent. ${ }^{80}$ And in a society based on free enterprise it is scarcely surprising that courts declined to meddle in the determination of equivalence, leaving that to the parties themselves. The focus of the law was on the process by which the parties determined equivalence, with bargain as the touchstone. The doctrine of consideration provided no ground for the enforceability of gratuitous promises, for which nothing is given in exchange, but it took good care of the bulk of economically vital commercial agreements.

The Elizabethan judges, though the choice was not consciously

83. Slade's Case, 4 Co. Rep. 92 b, 76 Eng. Rep. 1074 (Q.B. 1602).

84. Id. at 1077.

85. According to the Restatement Second, "To constitute consideration, a performance or a return promise must be bargained for," which means that "it is sought by the promisor in exchange for his promise and is given by the promisee in exchange for that promise." Restatement (SECOND) of CoNTracts \& 75 (Tent. Draft No. 2, 1965).

86. See R. Pound, An Introduction to the Philosophy of Law 144-46 (rev. ed. 1954). 
present to their minds, were impelled by every tradition of the common law to prefer the principle of bargain. . . . The large commercial interests of the new age sought a general sanction not for charitable gifts but for business enterprise. In such an environment it is not surprising that the judges should have required some material inducement to the defendant's underțaking, ${ }^{87}$

As a cornerstone for the law of contract, the doctrine of consideration has been widely criticized, and it would be foolhardy to attempt to defend it through an exercise in logic. It can be understood only in the light of its history and of the society that produced it. Yet in view of the difficulty that mankind the world over has had in developing any general basis at all for enforcing promises, it is perhaps less remarkable that the common law developed a theory that is logically flawed than that it succeeded in developing any theory at all.

\section{EPILOGUE}

Thus supported by a general theory, contract law reached its zenith in the nineteenth century as the legal underpinning of a dynamic and expanding free enterprise economy. It was not merely by chance that Maine's famous dictum about the progression from "Status to Contract" was uttered in 1861. Hurst concluded that the years from 1800 to 1875 were above all else the years of contract in American law.88 "Contract expressed energetic self-interest. Contract law expressed the nature of contract by insisting that men assert their interests, push them, and fight for them, if they were to have the help of the state." 89 "Nineteenth-century lawmaking in the United States gave its energy more continuously and more devotedly to building, extending, and implementing the market than to any other institution in the society. . . . The market took on legal definition mainly in the law of contract, and quite naturally in the temper of the time the law of contract dominated the nineteenth century legal order." 90

Philosophically, contract was supported by the will theory, which had its hegemony during the same century. It emphasized the power of the will of the parties, who were viewed as acting in a kind of legislative capacity, so that the enforcement of a contract by the state merely implemented a form of private law established by the parties. ${ }^{91}$ Morris Cohen has well stated its underlying assumption:

87. C. H. S. Fifoot, History and Sources of the Common Law; Tort and ConTRACT $398-99$ (1949). For more on the early meanings of "consideration," see W. BARBOUR, supra note 70, at 59-65.

88. J. W. HuRst, LAW AND the Conditions of Freedom in the Nineteenth CENTURY UNited States 18 (1956).

89. J. W. Hurst, Law and Economic Growth: The Legal History of the LUMIBER INDUSTRY IN WISCONSIN 1836-1915, at 301 (1964).

90. $I d$. at 285 .

91. Fuller and Perdue, supra note 72 , at 58. 
According to the classical view, the law of contract gives expression to and protects the will of the parties, for the will is something inherently worthy of respect. . . ${ }^{22}$ Contractualism in the law, that is, the view that in an ideally desirable system of law all obligation would arise only out of the will of the individual contracting freely, rests not only on the will theory of contract but also on the political doctrine that all restraint is evil and that the government is best which governs least. This in turn is connected with classical economic optimism that there is a sort of pre-established harmony between the good of all and the pursuit by each of his own selfish economic gain. ${ }^{23}$

But by the end of the century the tide in favor of contract had begun to turn. In Hurst's words,

Throughout the enthusiastic nineteenth-century expansion of contract, two sobering strains of doctrine attested that the courts never wholly lost sight of the fact that their enforcement of promises involved delegating the public force in aid of private decision making. ... By enforcing a contract, the public power supported the decisions the agreement represented and so far inescapably shared moral responsibility for the social consequences. ${ }^{04}$

Contract simply provided opportunities for the realization of men's wants; it did not shape those wants. "The cautious sense that contract alone was not a sufficient organizing principle for society never quite deserted us.",0

Now, in the twentieth century, the tide has been reversed. According to Friedrich Kessler,

The individualism of our rules of contract law, of which freedom of contract is the most powerful symbol, is closely tied up with the ethics of free enterprise capitalism and the ideals of justice of a mobile society of small enterprisers, individual merchants and independent craftsmen. . . . With the decline of the free enterprise system due to the innate trend of competitive capitalism towards monopoly, the meaning of contract has changed radically. ${ }^{27}$

Nathan Isaacs has argued that "the question is not so much one of status and contract as it is of a broader classification that embraces these concepts: standardized relations and individualized relations," there is now a "distinct veering back to status."

92. Cohen, supra note 66 , at 575 .

93. Id. at 558 .

94. J. W. HuRST, supra note 88 , at 11.

95. J. W. HuRST, supra note 89 , at 297 .

96. J. W. HuRst, supra note 88 , at 76.

97. Kessler, Contracts of Adhesion-Some Thoughts About Freedom of Contract, 43 CoLUM. L. Rev. 629, 640 (1943). Furthermore, as Fuller and Perdue point out, "The enormous growth of the corporation ... has meant a further decrease in the importance of contract as an organizing force, since the corporation and vertical integration tend to substitute for an organization resting on contract one resting on the relation of superior and inferior ...." Fuller \& PERDUE, supra note 72 , at 63 n.13.

98. Isaacs, The Standardizing of Contracts, 27 YALE L.J. 34, 39 (1917).

99. Id. at 40. 
Other changes have accompanied the standardization of relations that has been caused, at least in part, by this concentration of private power. Some of the decline in the importance of contract in achieving social purposes has resulted from a diminution in the extent to which society's material resources are subject to the control of individuals. In socialist countries such as the Soviet Union, all or at least a substantial part of productive wealth is owned by society as a whole and the right of private property is limited largely to consumption goods. Even in the so-called capitalist countries, possibilities for private ownership are limited. Such limitations vary from one country to the next. Cornelius Vanderbilt was able to amass a fortune in the United States out of railways, because they could be privately owned; he would have had no such opportunity in Germany, where the railways were always publicly owned. In contrast, the family of Thurn and Taxis became one of the most powerful in Europe through the private ownership of a postal system; while they would have been denied this opportunity in the United States, where the postal service has always been public. ${ }^{100}$ Whatever the precise limitations, to the extent that state ownership of a society's material resources comes to replace private ownership, the role of contract is diminished. ${ }^{101}$

Even without assuming ownership in itself, a society may severely restrict the freedom of the individual to contract. It may even write the contract itself, as for example many of our states have done for contracts for fire insurance and the federal government has done for ocean bills of lading. The French have used the term "contractual dirigism" to refer to a regime in which the state makes contracts for people instead of allowing the parties to make them themselves. ${ }^{102}$ "Legal regulation is substituted for contractual regulation. The contract is no more than the submission of the parties to an obligatory regime." 103 Short of wholesale dictation of terms, the state may use a variety of techniques to influence private agreements. It may, for example, stipulate particular terms with the balance left to agreement, as has been done with life, accident and health insurance; or it may merely prohibit or refuse to enforce particular terms, as in the case of laws flxing minimum wages or maximum interest rates. By methods such as these, entire industries, such as those engaged in communications, transportation, banking and insurance, have been brought under regulation. And, at the very least the state may endeavor to insure that those who are engaged in those areas where there is relatively

100. $1 \mathrm{R}$. Ely, Property and Contract in Their Relations to the Distribution OF WEAITH 80-83 (1922).

101. That socialist countries do use the institution of contract for state enterprises, see Grossfeld, Money Sanctions for Breach of Contract in a Commminist Economy, 72 YaLE L.J. 1326 (1963).

102. 2 L. Josserand, Cours de Droit Civil Posimif Français \$\$ $402-05$ (3d ed. 1939). See also R. Pound, AN Introduction to the Philosophy of IAw 161-63 (rev. ed. 1954).

103. 2 M. Planiol, Traité Elémentaire du Droit Civil \$ 446 (4th ed. by G. Ripert and J. Boulanger 1952). 
little governmental intervention (such as sale of goods) do in fact bargain in acceptable ways and are not so powerful as to allow coercion to substitute itself for bargain. It may, for example, prohibit undesirable trade practices and limit the concentration of economic power.

Most of these changes have come from the legislatures rather than the courts. Taken together they have spawned a plethora of contracts that are now regarded as within special fields of law that are separate and distinct from the general law of contract. There is, for instance, the collective bargaining agreement which is regarded as within the separate province of labor law, the insurance policy which is regarded as within the separate province of insurance law, and even the contract for the sale of goods which is often regarded as within the separate province of commercial law. These are delineated from an amorphous residuum that has been left largely to the judicially developed principles of general contract law.

It was not, of course, inevitable that contracts such as the collective bargaining agreement, the insurance policy and the contract for the sale of goods should be considered as appropriate subjects for separate fields of law outside of the general law of contracts. They might have been embraced within it and considered merely as species of the genus contract. That this did not happen was, at least in good part, the result of pedagogical circumstances.

In the first place, contract law was a parvenu as compared to such areas as tort law or criminal law, and it did not become the subject of important treatises until the nineteenth century. ${ }^{104}$ Contracts scholars then struggled manfully to fashion an orderly body of doctrine from the flood of case law that had been only a trickle two centuries before. It is scarcely surprising that their attention focused on those generalities that were common to most contracts rather than on those particularities that were peculiar to a few. Samuel Williston, in the first edition of his monumental treatise on contracts published in 1920, deplored the tendency to treat such subjects as insurance as outside the scope of contract law, and sought to "treat the subject of contracts as a whole, and to show the wide range of application of its principles." 105

Furthermore, since the creative forces of contract law had traditionally been judicial rather than legislative, the tendency was to regard contract law as essentially case law. In the accepted division of labor between judges and legislators, it was the former who were charged with the declaration of general principles and the latter with specialized deviations. It was thus no accident that when in 1871 Christopher Columbus Langdell published the first of the

104. See L. Friedman, Contract Law in America: A Social and Econonic Case STUDY 17-18 (1965).

105. S. Williston, A Treatise on the LaW of Contracts iii (1st ed. 1920). 
casebooks that were to revolutionize the method of law teaching, it was a casebook on contracts. ${ }^{106}$ When the adaptations of the law to special conditions came through legislation, contracts scholars tended to regard them as dehors the law of contracts. This view is still reflected in the introduction to the Restatement (Second) of Contracts, which explains that it

attempts [no] comprehensive statement of the rules governing particular types of contracts, [n] or of the impact of modern legislation on the law of contracts.... Legislative changes in the law of contracts are incorporated in the Restatement of this Subject only where substantially similar legislative rules have been adopted in most of the States. . . Various types of contracts are subjected to government regulation in varying degrees of detail. ... But no effort is made here to state comprehensively the rules governing statutory obligations imposed on contracting parties regardless of their assent. ${ }^{107}$

This concentration of contracts scholars on a residual core of generalities has occasioned some sharp criticism:

Contract law is abstraction-what is left in the law relating to agreements when all particularities of person and subject matter are removed. ... By definition, no revolution [in nineteenth-century contract law ] could take place because contract law acted as a residual category, its content determined mainly by what law did in other respects affecting economic behavior. Instead, types of transaction marched in and out of the area of contract. ${ }^{108}$

This criticism is, of course, directed at the conception of contract law held by contracts scholars rather than at the law itself. To the extent that they have viewed related transactions as marching in and out of the area of contract, they might better have disregarded the "boundaries" of the area and devoted their time to "examining the territory on both sides."109 Happily, the advent of the Uniform Commercial Code, ${ }^{110}$ with its emphasis on the contracts problems arising out of the sale of goods, has provided contemporary contracts scholars with an occasion for just this type of examination.

A related criticism goes to the supposed failure of contracts scholars to give adequate attention to the economic and social significance of contract law. "An exposition of 'current' contract law will typically tell nothing of the economic importance or unimportance of particular precepts; whether they are adhered to in practice or not; whether they pertain to living issues or to rare or peripheral situations." ${ }^{111}$ Some of the reluctance of contracts scholars to inquire into the economic importance of contract law may be due to the fact that such inquiry reveals an erosion, an erosion resulting from the com-

106. C. Langdell, A Selection of Cases on the Law of Contracts (1871).

107. Restatement (SeCOND) of Contracts 1, 3-4 (Tent. Draft No. 1, 1964),

108. L. FRIEDNLAN, sulpra note 104 , at $20,23$.

109. Treitel, Book Review, 33 U. CHI. L. Rev. 418, 423 (1966).

110. The Code is now law in 49 states.

111. L. FrIEDMAN, supra note 104 , at 10. 
bination of two circumstances. The first is that, particularly because of its growth during the nineteenth century, contract law came to be identified with free enterprise and the competition of the market. As the state, usually through the legislature, began to intervene through restrictions on freedom of contract in particular areas, it naturally chose those areas in which the market mechanism was thought to be inadequate, shrinking the scope of application of traditional contract law but leaving its identification with free enterprise and the competition of the market largely untouched. The second circumstance is that it is in those very "unmanaged" portions of our economy, where the market mechanism works well by itself with little or no need for regulation, that the compulsion afforded by legal sanctions is least. By affording legal sanctions for the enforcement of promises, society hopes to make it more likely than it would otherwise be that promises will be kept; private decision is supported by public force. Max Weber defined

the existence of a right as being no more than an increase of the probability that a certain expectation of the one to whom the law grants the right will not be disappointed... . To the person to whom something has been promised the legal guaranty gives a higher degree of certainty that the promise will be kept.112

But legal sanctions are only one of several types of compulsion that contribute to the honoring of promises.

John Henry Wigmore spoke of two other kinds of sanctions: "ethical" and "social," in addition to "jural." ethical compulsion arising out of "the personal moral sense; e.g., the pressure of conscience." Equally important may be the social compulsion arising out of "the potential action of some portion of the community . . . as feared, admired, or respected by the individual; e.g., the felt pressure of public sentiment." "To say 'it pays to be honest' is wrong emphasis. The clearer view is that it is highly dangerous, economically, to be dishonest."114 Sebei law, for example, is said to be weak in legal sanctions for the enforcement of promises and performance may consequently be long delayed. Such force as promises have is "ensured by mutual interdependence, by the operation of a market in which each party to the contract had an ultimate interest in preserving his public reputation; his very survival in the community, and certainly his social

112. M. WEBER, supra note 40 , at 98 .

113. Wigmore, The Scope of the Contract-Concept, 43 Conur. L. Rev. 569 (1943). For a good discussion of sanctions, see H. Havighurst, The Nature of Private ConTRACT 45-92 (1961).

114. H. Scherdinn, The Promises Men Lrve By 70-71 (1938). The author points out that at one time men relied on fear of the gods, but that the State has replaced the Church in this respect. Id. at 72-73. Societies have various means to trigger the compulsions that do not proceed from the State. Thus it is said that the Chinese creditor might threaten suicide and the Indian creditor might starve himself on the debtor's doorstep. Schapera notes that the man who engages a magician for "doctoring" may be induced to pay out of fear that the magician will undo his "doctoring" or bewitch his defaulting clients. I. ScenAPERA, supra note 46 , at $202 ; \mathrm{M}$. Weber, supra note 40 , at 114 . 
and economic advancement, depended on his fulfilling the legitimate obligations he had incurred." 115 Much the same can be said of ours, or any other society for that matter, since as expressed by Eugen Ehrlich, "the individual is never actually an isolated individual; he is enrolled, placed, embedded, wedged into so many associations that existence outside of these would be unendurable. ..."116 Furthermore, as Harold Havighurst has pointed out, the very nature of contract is such that non-legal sanctions take on special importance, since "the opportunity to injure a man by breaking a contract is open only to those with whom he has chosen to deal. ... A man by selection can limit the circle of those in a position to hurt him by failing to keep a promise."117

The relative importance of legal and non-legal compulsions will vary according to the circumstances. Non-legal compulsions will be relatively inportant when two merchants deal on an established market. The ethical compulsion will be strong because the relationship is reversible in that each party realizes that their roles might be reversed in some subsequent transaction - "that the same duty you owe me today, I may owe you tomorrow."118 And the social compulsion will be strong because the relationship is continuing, so that even should a dispute arise, each party has an interest in engaging with the other in further transactions in which future dependability will be judged by past performance. For these reasons the compulsion of legal sanctions is relatively less significant than would be the case, for example, when a landlord and a tenant execute a lease of an apartment. The ethical compulsion will be weaker because the relationship is not reversible and neither expects to assume the opposite role in another transaction. And the social compulsion will be weaker because should this transaction provoke controversy, neither party will be likely to have an interest in dealing with the other in the future and there will be no occasion to look to past performance as a guide to reliability. Here the relative significance of the compulsion of legal sanctions is relatively greater.

In short, as a result of the combination of these two circumstances, the area of principal applicability of contract law is one in which the significance of legal sanctions is hikely to be comparatively slight, and where, in consequence, disputes are brought before the courts relatively infrequently. This is borne out by the fact that the typical contracts casebook draws heavily upon disputes that arise outside of established markets, such as those that stem from family transactions, ${ }^{119}$ and upon those that arise when an established market

115. W. Goldscharidr, Seber Law 221 (1967).

116. E. Ehrich, Fundamental Princtples of the Sociology of Law 62 (Eng. trans. 1936).

117. H. HAvighuRST, supra note 113, at 69-70. He points out that there are exceptions, e.g., the settlement of a tort claim. Id. at 79 .

118. L. Fuller, The Morality of Law 23 (1964).

119. Classics are: Earle v. Angell, 157 Mass. 294, 32 N.E. 164 (1892) (aunt and nephew) ; Di Cicco v. Schweizer, 221 N.Y. 431, 117 N.E. 807 (1917) (fiance and prospec- 
suffers an abnormal dislocation, such as those that are occasioned by the outbreak of war..$^{120}$

It must be borne in mind, however, that the law's particular concern is the resolution through its procedures and sanctions of precisely those disputes that cannot be resolved by other means. As Karl Llewellyn emphasized, "This work of the law machine at the margin, in helping keep the level of social practice and expectation up to where it is, as against slow canker, is probably the most vital single aspect of contract law. For in this aspect each hospital case is a case with significance for the hundreds of thousands of normal cases." ${ }^{21}$ It would be absurd to suppose that an analysis of such disputes would yield a reliable picture of the economy, and it is scarcely surprising that the case law focus of contract law tends to emphasize problems of only marginal economic importance. Fortunately, the advent of the Uniform Commercial Code, with its comprehensive statutory formulation of rules for the settlement of disputes arising out of contracts for the sale of goods, has helped to shift the focus, at least in this area, from those disputes that characteristically turn up in court to those that are settled out of court, but nevertheless with some attention to legal rules as well as business expediency. In addition there is a growing interest among contracts scholars in empirical research, to determine the actual impact of legal doctrine in practice, and to consider the reshaping of legal rules in the light of these findings.

Finally, there can be little doubt that the field of contract law, however conceived, now must share a stage on which, in the days of the nineteenth century, it held the undisputed center. Indeed, few would wish a return to the time of unbridled free enterprise in which contract played the principal role. This is not to say, however, tbat less attention should be given to the foundations of this vital subject. As a perceptive contracts teacher wrote several decades ago,

The law school curriculum of the twentieth century will probably show a diminishing relative emphasis on the various branches of commercial law. The clearer formulation and teaching of its funda-

tive in-laws) ; Hamer v. Sidway, 124 N.Y. 538, 27 N.E. 256 (1891) (uncle and nephew); Balfour v. Balfour, [1919] 2 K.B. 571 (C.A. 1919) (husband and wife).

120. Examples are: Lloyd v. Murphy, 25 Cal. 2d 48, 153 P.2d 47 (1944) (World

War II) ; Tsakiroglou \& Co. v. Nobles \& Thorl [1961] 2 All E.R. 179 (closing of Suez Canal). For an indictment of current contracts teaching and research, see Friedman and Macaulay, Contract Laze and Contract Teaching: Past, Present, and Future, 1967 Wis. L. REv. 805, which appcars in slightly different form as Contract Law and Contract Research, 20 J. LEGAL ED. 452 (1968). Havighurst mentions five sorts of circumstances in which non-legal sanctions fail: "(1) The debtor dies. . .. (2) Evil men without conscience and not responsive to any relevant social pressures suceeed in entering the circle of the trusted.... (3) The debtor is subject to little competitive pressure.... (4) The debtor, because of insolvency or for some other reason, finds it impossible or difficult to perform. ... (5) Controversy develops [as, for example, over the meaning of language]." H. HAvigh URST, supra note 113, at 74-75.

121. Llewellyn, What Price Contract?-An Essay in Perspective, 40 YALE L.J. 704, 725 n.47 (1930). 
mental principles will tend to make this possible without sacrificing any of its substance, and will enable it to take its proper place in the law of the more complex age that is to come. ${ }^{122}$

The objective of this article has been to provide a perspective that will make this possible.

122. Gardner, An Inquiry Into the Principles of the Law of Contracts, 46 HaRv. L. Rev. 43 (1932). 
Practically speaking, however, does traditlonal contract doctrine have the importance we attach to it? The principle setting of the contract is the executlive's office or the businessman's shop. Is contract doctrine realistic when the setting is considered? Does it recognize what In fact is business practice? Should it? Just what is the role of contract doctrine in a modern industrlal society?

Professor Macaulay who has faced these questions is emphatic. He believes that traditional contract law, and the teaching of it, is economlcally Irrelevant and unrealistic. Conslder the following excerpt from L. Freedman and S. Macaulay, Contract Law and Contract Teaching: Past, Present, and Future, 1967 WIsc. L. Rev. 805, 812:

\section{CRITICISM OF OUR TRADITION}

The alm of education is to teach signlficantly. But contract doctrine, and the problems this doctrine is concerned with, are arguably not significant In a number of senses. The problems themselves are not empirically significant. They do not concern many partles or mean much to the soclal order. In some instances, the problems are rare in occurrence or litigation (e.g.. the problem whether an acceptance to an offer is Irrevocable when dropped In a mal (box). Or the problem is only "common" if posed In terms highly abstract; while in terms of concrete situations, the problem is too complex to be solved by general princlples. Or the problems are not In fact solved through the use of contract; that is, actual case law uses contract doctrine only as rationalization, or (even more significant) partles typlcally or almost Invariably use means other than contract doctrine to work out difflcultles that occur during bargaining or during the 11 fe cycle of a contract. We wlll explore all of these matters in some detall.

Perhaps lack of significance is inherent in the traditlonaliy-concelved sphere of contract law. Insofar as the subject matter of contracts is the goverance of economic exchanges in the business world, when problems become soclally significant enough to be $\mid 1+$ lgated $w 1$ th any frequency, they tend to be "removed" to new areas of the law where contract doctrine is elther Irrelevant or plays a minor role. No contracts problem in a concrete sense --one that is frequently $11+$ igated and which deals with one speclfic typesituation-lasts more than two generations. The fundamental concepts of traditional contract law--offer, acceptance, consideration, and the IIke-are Instruments far too general and abstract to regulate current, soclally signiflcant business problems. When problems reach the threshold of public or general business concern, they are solved or at least coped with by other means--by leglslation, for example. Thus insurance statutes, labor laws, and antitrust legislation cover vital aspects of transactions once fully or largely within the ancient domain of contract. Other problems simply die out or are drafted out of existence by organlzed business interests. Contracts casebooks, for example, lovingly preserve many construction- 
Contract cases that, whatever "fundamental" issues they may raise, are obsolete as construction-contract cases because the construction business is no longer conducted that way. Standardlzed forms and modes of transacting business have made it impossible for many great contract cases to recur in their precise, contextual form--yet it is context which breathes Ilfe into law. Without context, what remain are puzzles in dead languages.

Even where contract doctrlne has not been displaced, It plays a very restricted role in governing business transactions as compared with its press notices. This body of law is said to support the exchange operations of our economy because without it rellance on promises, plans about the future, and rational allocations of the costs of uncertalnty would be all but impossible. This sounds important, and it would be if contract doctrine served such a function. But the case is overstated.

At the outset, what do we mean when we talk about contract law? Professors of contract law usually are concerned with the following kinds of apparently significant problems:

(1) Definlng the point of formation of a contract, that point at which one cannot back out of an arrangement without belng llable for damages;

(2) Establishing criteria by which one party may Invoke legal sanctions, or prevent the other party from invoking them, In ways that will prompt bargains to be made so that their content is socially deslrable as measured by some standard;

(3) Aiding the performance of contracts by defining obllgations through interpretation and gap-filling and by providing incentives to perform through the potentlal avallabllity of a cause of action for damages; and

(4) Compensating one who has suffered injury, as defined by the law of contract remedies.

Thls is what goes on in law schools. But what goes on in business offices, in lawyer's offices, and in the courts? Most businessmen in most industries plan transactions and settle disputes in ways that make these classic functions of contract law largely irrelevant. In most kinds of transactions, businessmen are very unlikely to worry about whether the contract they are negotlating is cast in proper form to make it legally enforceable. Thus, they are not often Interested in the polnt of formation or the criterla for galning legal sanctions, two of our favorite law school problems. For example, it the contract is to last over any perlod of time, businessmen are likely to clutter up the arrangement with clauses that leave matters "to be equitably agreed upon" later. They are llkely to be extremely vague about whether they are making "offers" in a legal sense. Moreover, they are very Ilkely to start performing before all of the necessary contract "formalitles" are complled wlth. Finally, many businessmen assume they have the right to cancel a contract before signlficant, tangible rellance has occurred, and many assume that replacement, repalr, or rellance damages are, or ought to be, the limit of llabllity; one who 
would seek consequential damages is asking for something he has not yet earned.

If a lawyer is invited to the negotlations, he is unllkely to let his cllent begin. work with no more than an agreement to agree or on the basis of an oral side promise adding to and modifying a written contract. However, very frequently a lawyer wlll not be invited to the party. Modern purchasing agents and sales managers feel quite able to dispense with the annoyance of legalistic advice, as do many other buslness officlals who conduct negotlations and commit their organizations. By and large, the lawyer is called in only if businessmen foresee potential antitrust or tax problems, if they need a $+1+1 e$ examined, or If they percelve the lawyer as skilled in the use of language. Even when the lawyer is asked to look over a contract that has been worked out by bus Inessmen, often he must approve one that may not be legally enforceable. His cllent and the other party may want to leave a vital contingency "to be equitably agreed." To force them to work out all al locations of risk at the outset might expose some of the strains in the relationship that the process of negotiation had hidden. As a result, the client might lose the deal, and usually thls rlsk is too high a price to pay for the few benefits of a legally enforceable contract. Also, at times, lawyers whose cllents wleld great economlc power work hard to keep contracts from belng legally enforceable in order to be sure that the other party gets no rlghts against thelr cllent. The automobile manufacturers specialize in this kind of arrangement.

While this lack of concern about contract law is probably more common In planning sales of shelf goods than in elaborate financing arrangements between a group of lenders and a borrower of large sums, the lack of concern about contract very frequently can be seen In all kInds of transactlons at the stage of performance and settlement of disputes. Even when much expensive legal work has gone into drafting an elaborate and legally enforceable contract, the document is very often buried in a forgotten flle folder whlle the bus Inessmen, brokers, bankers, agents, and others "work things out" on the telephone, In conferences, or on the golf course. One important businessman said In the course of an intervlew, "If something comes up, you get the other man on the telephone and deal with the problem. You don't rrad legalistic contract clauses at each other if you ever want to do business agaln. One doesn't run to lawyers if he wants to stay in business because one must behave decently."

Typlcally, lawyers are brought into the dlspute settlement process only as a last resort. And this is true even in large corporations where legal advice is readily aval lable at no extra cost. The house counsel and the business lawyer in private practice spend time on taxation, antitrust, falr trade, and the Rob inson-Patman Act, not on offer and acceptance or constructive conditions. Thus most businessmen, and many business lawyers also, are not very concerned about gap-flllilng and remedles for breach of contract--the other two problems of orthodox contract teaching and research.

And why is contract doctrine not central to business exchanges? Brlefly put, prlvate, between-the-partles sanctlons usually exist, work, and do not involve the costs of using contract law either in IItigation or as a ploy in negotlations. To begin with, business relationships rarely 
generate the kinds of problems considered by academic contract law. There is a constant pressure to standardize business and reduce recurring patterns to a routine. Routine and form create widely shared expectations so that people can understand who is to do what, quite apart from the words of a formal contract. Then, too, business units are organlzed to carry out their commitments. An executive must stop a whole organization if he wants to breach an agreement, and many members of that organization will have reasons of their own to want to perform. For example, sales employees, who must deal with purchasing agents on a face-to-face basis represent the interests of the customer within the seller's organization; financlal emp loyees represent the bankers who have loaned it money.

Businesses of all kinds have tended to develop stable economic relationships. Therefore, the two businesses Involved in any kind of deal are likely to be interlocked beyond the fact of a partlcular contract. No one disagreement would justify jeopardizing a total relationship. Personal relationships may exist across all levels of the two organlzations involved. Executives, for example, are likely to know each other soclally: one behaves differently with friends than wlth strangers. Today, if not in the past, most people in most kinds of businesses share a norm of honoring commitments unless there is an extraordinary reason not to- And most importantly, there are relatively few one-shot, but significant, deals. A businessman usually cares about his reputation. He wants to do business again with the man he is dealling with and with others. He will have a harder time getting business if he is known as a "chiseler," one who will not keep $h$ is word, or even one who always demands the letter of his rights and will not "work things out." And reputations have a way of becoming known: business has an effective Intelligence system.

Not only is contract law not needed in many situatlons, Its use may have, or may be thought to have, highly undesirable consequences. Detalled and carefully planned arrangements may create undesirable exchange relationships. A businessman often wants to create a kind of partnership for a limited purpose, with a great deal of sharing of losses and joint responsibllity for problems hard to foresee. He will leave gaps in his contract, since an attempt to make an alrtight contract at the negotiation stage may encourage the other party to be equally a stickler for the letter of the bargain rather than a member of the team. Use of contract doctrine may be a positlve llability in maintaining an ongoing relationship. Coercion (and even a tacit threat to sue is coercive) is inconsistent with an atmosphere of trust and cooperation in the face of adverse circumstances.

Once there is a serlous dispute, most bus inessmen are eager to cut their losses and move on to the next transaction. A salvage operation wlll not interest them unless they are convinced that it will offer a good return on the necessary investment in it. Unfortunately for contracts teachers, this is not often the case. Moreover, in situations where disputes are fairly frequent, substitutes for contract litigation tend to appear-modes of arbitration or mediation, elther formally or informally fostered by trade associations, the good of fices of varlous governmental agencies, or even by the efforts of financlal institutions with interests in both parties. 
While It is important to see that contract law very frequently plays no real role In bus iness for all of the reasons we have just discussed, it is also Important to see that the role it does play is not the one usually emphaslzed in contracts courses or research. On the one hand, doctrine often becomes something to draft around, so its impact is avolded in those types of transactions where an attorney is allowed to be in on the planning stages. Frequently this is done through the drafting of business forms, such as the American Institute of Architects' forms for residentlal building construction or the new purchase orders and acknowledgements that attempt to repeal much of the UnIform Commerclal Code. On the other hand, sometimes contract law may support private informal means of solving problems. In some situations the chance that one party might sue for breach of contract or that he might win such a sult may be part of the total plcture of diplomancy, bluff, and leverage leading to a settlement. In other situations, contract doctrine may serve the loophole function. One party can assert a technical doctrinal argument as part of his effort to undercut his obligation and defeat the expectations of the other. We have very Iittle systematically gathered knowledge about such functions of contract. What evidence we do have indicates that these roles are not common. The costs to one 's reputation and business relationships of threatening to sue or using a loophole are extremely high. If supporting private means of solving problems is the real functlon of contract doctrine, as some seem to have asserted, much more needs to be known: How does the process work? What effect does contract doctrine have in what kinds of situatlons? What is the significance of the many situations where contract doctrine plays no such role? The burden of going forward with the evidence now rests on those who would stand on this justification for the traditional approach to contracts teaching and research.

Of course, we recognize that in some kinds of sltuations classlc contract doctrine does serve to solve problems that matter to the partles. And one must concede that frequency is not the sole criterion of significance. However, frequency is an important one. Surveys of the typical kinds of cases in which contract doctrine solves such problems prompt us to ask whether or not these problems are important enough to call for the Investment of all the intel lectual effort that has gone into refining contract doctrine in the abstract. The evidence we have indicates that the common klnds of appellate cases are: atypical or freak business transactions; economically marginal deals both in terms of the type of transactions and amounts Involved; high-stake, zero-sum speculations; deals where there is an outsider interest that does not allow compromise; and famlly economic transactions. Clearly the cases in the reports today seidom fit the model elther of the horse trade or the modern bureaucratic transaction. Romanticized versions of the functlons of contract law seem to flt the facts poorly. Moreover, the legal response called for by actual litigation usually has little or nothing to do with the concepts of offer and acceptance, impossibility, conditions, or the other categories typlcally thought to be part of "contracts" as we see it in law school. Rather, these cases call for interpretation of language and rational or ethical allocations of losses. A sense of fairness and meticulous attention to the particular facts of the case, rather than concern with "general princlples of contract law," are the guiding stars of decision. 
So much for the restricted role of contract. Yet even in those few areas where contract doctrine or contract problems are clearly or potentlally significant, legal education and research do not now provide relevant theory and satisfactory solutions to current problems. This is inevitable in the light of our minimal commitment to discovering the actual consequences of the operation of the legal system. For example, Uniform Commerclal Code section 2-207 attempts to solve the problem of the "battle of the forms"; it requires that sellers read all orders carefully, or, in effect, grant full warrantles subject to a llability for consequential damages. This is a warranty that industrial sellers almost never give voluntarlily. To avold section 2-207, business would have to train a large staff to read an immense volume of small print. No wonder many house counsel find this Code provision blzarre. The section was apparently drafted without assessing costs and without balancing against them the advantages the section might afford. A related sin, prompted at least partially by our traditlons of legal education and research, is that we overlook problems--even soclally important problems - - untll they are embalmed in an appellate case. It was traditional case law that made the draftsmen of the Code feel they had to do something about the battle of the forms. Conversely, case law orlentation has led to the neglect of the whole range of consumer problerns. Our categorles make it difficult for us to conslder the actual operations of the large modern business corporation when it offers its wares in the market. Of course, we all know that corporations use contract doctrines in order to legislate unilaterally Most of us know about such "contracts of adhesion," at least since Professor Kessler's excellent article, 2 but where are the studies of the patterns actually used and the careful analysis of the desirability or undesirabillty of each? ${ }^{3}$ For example, consumer warranty disclaimers in small print existed long before the now famous Henningsen case, 4 they are still widely used in the sale of products other than automobiles. Even after that landmark decision has been immortalized in many of the casebooks, there is yet to be published a study of the actual impact of the case on auto safety, injured consumers, car prices, or the practices of manufacturers. It also seems likely that the parol evidence ruje and the procedural and practical restrlctions on the law of fraud support the exploltation of the poor by certain kinds of businessmen; conversely, certain tricks of offer and acceptance often can be used to bail a legal aid cllent out of a contract for pots and pans. Yet where is the research into this kind of practice? Where are the proposals for reform based on a realistic assessment of potenthal galns and costs? Or thelr rebuttals? What casebook really devotes any effort to this kind of problem?

[Footnotes are renumbered--some have been omitted.]

I. E.g., Poel v. Brunswick-Balke-Collender Co., 216 N.Y. 310, 110 N.E. $619(1915)$.

2. Kessler, Contracts of Adhesion--Some Thoughts About Freedom of Contract, 43 COLUM. L. RE. 629 (1943).

3. For one such analysis, see Macaulay, Private Leglslation and the Duty to Read--Bus Iness Run by IBM Mach ine, The Law of Contracts and Credit Cards, 19 VAND. L. REV. $1051(1966)$.

4. Henningsen v. Bloomfleld Motors, Inc. 32 N.J. 358, 161 A.2d 69 (1960). 
While studying the following materials, ask yourself (1) whether the authors are correct in the statements that businessmen tend to wait until the last minute before bringing In the lawyer (there is opinion to the contrary) and (2) assuming that they are correct, whether you agree with these general conclusions concerning their relevance of contract doctrine in today's society. 
11. "FREEDOM" OF CONTRACT

Private volition is the core around which the idea of contract is centered. This core is the expression of a basic tenet on which our underlying political and economic structure is grounded: the freedom of choice-a belief that the individual alone should determine his future. He decides what he wants and plans to provide for these wants: He insures against future risks. The contract is the means through which he does this planning. The employee who enters into the employment contract, the insured who purchases a llife insurance pollcy, and the lessee who enters into a lease agreement are using the contract to determine, as best he can, some aspect to their future. If you consider the business corporation as an Individual, you will see how the free enterprise system is based on freedom of contract.

Obviously, a bellef in freedom of contract does not preclude restrictions and controls on Individual vollition. From the time that courts and legislature sald that the parties to a contract must be "competent" and of "fuli age," or that contracts in restraint of trade are invalld, the Individual's freedom to contract has been restricted so that some broader social or economic, goal can be attained. Contemporary consumer protection laws restrict the merchant's as well as the consumer's freedom to contract. The extent of the restriction in this and other areas depends upon the political, social, economic and rellglous climate at the time the question arises.

The cases in this section illustrate some of the situations in which the freedom versus control dichotomy arises. They are intended only as an introduction. Add to this introduction as you study subsequent cases.

When reading these cases, ask yourself the following questions: What are the circumstances behind the freedom versus control issue? What is the court's reasoning for enforcing or not enforcing the agreement? What is the effect of the decision? Was the decision "just"?

One final note. As you read the cases in these materlals, notice the many and different situations in which you find the contract. What connection does the Wall Street atmosphere of Guttman, P. 42, have to the labor setting of Mabley, p. 47? How does Mabley relate to Balfour v. Balfour, p.101? When the string you are using to tle the cases together becomes strained, remember that the principles of contracts cannot be studled without considering the clrcumstances which gave use to this principle. Keep in mind the following words of Professor Sharp and KIssler:

- . [a] monistic approach serves only to distract the real role which contract has played in the evolution of our soclety. It results in more or less lifeless abstractions and achieves at best a "formal," but not "a substantlal" rationality. A realistic understanding of the law of contracts can be achleved only through an awareness of the different functions fulfilled by the varlous kinds of contract in our soclety. This diverslty of functions leads inevitably to a polytheism of ideals governing the law of contracts. A pluralistic approach may help to explain the many tensions and inconsistencles which become apparent upon a close 
study of the case law and whlch cannot be explained satlsfactorlly under a monistlc approval.

F. Kessler and M. Sharp, Contracts: Cases and Materlals I (1953).

GUTTMANN $\vee$. ILLINOIS CENTRAL R.R. CO.

189 F.2d 927 (2d Clr. 195I)

[Footnotes are renumbered--some have been omltted.]

FRANK, CI rcult Judge.

The issue then, is whether the directors could valldly declare a dividend on the common stock in 1950 without directing that there should be pald (In addition to preferred dividends on the preferred for that year) al leged arrears of preferred dividends, the amount of which had been earned in 1942-1947 but remalned undeclared and unpaid. To put it differently, we must declde whether (a) the directors had the power to declare such alleged arrears of dividends on the preferred and (b) whether they "abused" their discretion in declaring any dividend on the common without ordering the payment of those al leged arrears.

Our lode-star is Wabash Rall way Co. v. Barclay, 280 U.S. 197, 50 S.Ct. 106, 74 L.Ed. 368, which dealt with the noncumulative preferred stock of an Indiana rall road corporation. There were no controlling Indiana decislons or statutes on that subject, The United States Supreme Court was therefore obliged to Interpret the contract according to its own notlons of what the contract meant. We have a similar problem here, since there are no IIIInols decisions or statutory provisions which control or gulde us. Absent such declsions and statutes, we must take the Wabash op inion as expressing the correct interpretation of the rights of non-cumulative preferred stockholders of this lllinois company. For the difference between the language of the preferred stock here and that in Wabash seems to us to be of no moment.

In the Wabash case, plaintifts, holders of non-cumulative preferred stock, sought an injunction preventing the defendant rall road company from paying dividends on the common stockl unless it first pald dividends on the non-cumulative preferred to the extent that the company, in previous years, had had net earnings avallable for that payment and that such dividends remalned unpald. The Court declded agalnst the plaintiffs. It spoke of the fact that, in earller years, "net earnings that could have been used for the payment were expended upon Improvements and addItions to the property and equipment of the road"; It held that the contract with the preferred mean that "If those profits are justiflably applied by the directors to capltal improvements and no dividend is declared within the year, the claim for that year is gone and cannot be asserted at a later date."

1. And on a class of preferred stock having rights junlor to those of the preferred stock held by the plaintiffs. 
We take that as a rulling that the directors were left with no discretion ever to pay any such dividend. For if they had had that discretion, it would surely have been an "abuse" to pay dividends on the common while disregarding the esserted claim of the non-cumulative preferred to back dividends. Indeed, the plaintiff in the instant case contends that a payment of common dividends, whenever there is such a discretion, constitutes an unlawful 2 "diversion"; and such a "diversion" would be an "abuse" of discretion.2

Plaintiff, however, seeks to limit the effect of the Wabash ruling to Instances where the net earnings, for a given year, which could have been pald to the noncumulative preferred, have once been expended justiflably for "capital improvements" or "additions to the property or equipment." $\mathrm{He}$ would have us treat the words "non-cumulative" as if they read "cumulative if earned except only when the earnings are pald out for capltal additions." He argues that the Wabash ruling has no application when net earnings for a given year are legitimately retalned for any one of a variety of other corporate purposes, and when in a subsequent year it develops that such retention was not necessary. We think the attempted distinction untenable. It ascrlbes to the Supreme Court a naive over-estimation of the importance of tanglbles (because they can be touched and seen) as contrasted with intanglbles. Suppose the directors of a corporation justifiably invested the retalned earnings for the year 1945 in land which, at the time, seemed essential or highly desirable for the company's future welfare. Suppose that, in 1948, 1t turned out that the land so purchased was not necessary or useful, and that the directors thereupon caused it to be sold. PlalntIff's position compels the implled concession that the proceeds of such a sale would never be avallable for payment of so-called arrears of unpaid non-cumulative preferred dividends, and that the directors would forever lack all discretion to pay them. We fail to see any intelligible difference between (1) such a situation and (2) one where annual earnings are properly retalned for any approprlate corporate purpose, and where in a later year the retention proves wholly unnecessary. 3 There is no sensible ground for

2. This becomes the more evident when it is noted that the plaintiff asserts that "non-cumulative" means in effect, "cumulative if earned." For directors have no discretion to pay common dividends without paying arrears of cumulative preferred dividends.

3. The attempted distinction would also come to this: (a) The noncumulative preferred irrevocably loses all rights to a dividend as of a given year, if the earnings for that year are invested in fixed capital, but (b) has an inchoate right in the form of a sort of contingent credit if those earnings are reasonably retained for future investments which are never made and which thereafter show up as wholly unnecessary. This is to say that the preferred take the risk of loss of a dividend as of a year in which it is earned when there is a reasonable need for a present capital investment, but no such rlsk if there is a present reasonable 11 kellhood of a need for such an investment in the future, which later appears undesirable. We see no rational basis for such a distinction. 
singling out leglitimate capltal outlays, once made, as the sole cause of the irrevocable desfruction of the claims of the preferred. We do not belleve that the Supreme Court gave the contract with the preferred such an irrational interpretation. It simply happened that in the Wabash case the earnings had been used for capltal additions, and that, accordingly, the court happened to mention that particular purpose. Consequently, we think that the Court, in referring to that fact, did not intend it to have any significance. : .

Here we are interpreting a contract into which uncoerced men entered. Nothing in the wording of that contract would suggest to an ordinary wayfaring person the existence of a contingent or inchoate right to arrears of dividends. The notion that such a right was promised is, rather, the invention of lawyers or other experts, a notion stemming from considerations of falrness, from a pollcy of protecting investors in those securities. But the preferred stockholders are not--llke sallors or idlots or infants-wards of the judlclary. As courts on occasions have quoted or paraphrased anclent poets, It may not be I nappropriate to paraphrase a modern poet, and to say that "a contract is a contract is a contract." To be sure, it is an overstatement that the courts never do more than carry out the intentions of the partles: In the interest of fairness and justice, niany a judge-made legal rule does impose, on one of the parties to a contract, obligations which neither party actually contemplated and as to which the language of the contract is silent. But there are limits to the extent to which a court may go in so interpolating rights and obligations which were never in the parties' contemplation. In this case we consider those IImits clear.

$$
\text { *** }
$$

From the polnt of view of the preferred stockholders, the bargain they made may well be of a most undesirable kind. Perhaps the making of such bargalns should be prevented. But, if so, the way to prevent them is by legislation, or by prophylactic administrative action authorized by legislation, as in the case of the S. E. C. in respect of securities, including preferred stocks, whether cumulative or non-cumulative, issued by public. utility holding companles or thelr subsidlarles. "The courts are not empowered to practice such preventive legal mediclne, and must not try to revise, extensively, contracts already outstanding and freely made by adults who are not incompents.

AffIrmed.

4. See In the Matter of The North American Company, 4 S.E.C. (1939) 434 , 462 (dissenting opinion).

There it is pointed out, Inter alia, that the provisions of many cumulative preferred stocks create bargains that are most undesirable, but which the courts nevertheless enforce.

There are those who think that no sort of preferred stock should be permitted because, among other things, of the unavoldable perplexities which they frequently occasion for conscientious directors owing allegiance to classes of stockholders with interests often in conflict.

44. 


\section{NOTES}

(1) A share of stock represents an ownership and financial interest in a corporation. Each share gives to the holder of it, the shareholder or stockholder, a proportionate interest in three rights: (1) the right to profits in the form of dividends; (2) the right to assets after all creditors have been paid when the corporation is dissolved; and (3) the right to elect the board of directors and to pass on major changes in the corporation. The shareholder's right to dividends does not arise, however, until dividends are declared by the board of directors; it does not arise wherever profits are earned unless the articles of incorforation make dividends mandatory. This is essential to a case like Guttman in which the directors did not, and were not required by the articles, to declare dividends. The plaintiffs were arguing that even though the articles did not make the declaration of dividends mandatory, the law should. What was the basis of plaintiffs' argument?

Generally, shareholders are grouped into two classes: common and preferred. To understand the difference between the two, you must first realize that the relationship between a shareholder and his corporation is essentially contractual. The shareholder contributes money or property to the corporation in return for the rights mentloned above. He also agrees to accept the risk of loss, that is, a loss of his investment should the corporation fall. In this respect, he differs from the credltor. The common shareholder can gain and lose the most. He agrees to contribute money to the corporation on condition that after all credltors and preferred shareholders are paid, he is entitled to the remainder. The more profltable the corporation the more the common shareholder stands to gain. If the corporation goes bankrupt, the common shareholder usually loses everything.

The preferred shareholder stands one step above the common shareholder. He is "preferred" over the common shareholder. The preference usually extends to dlvidends and assets; he wlll receive set amounts of dividends and assets on liquidation before the common shareholders are entitled to anything. In return for this preference (risk protectlon), preferred shareholders usually are not entitled to vote for directors. It is not difficult to realize that preferred shareholders purchase their stock in the hopes of collecting dividends annually. Dividends are to them interest payments. So that preferred shareholders can collect dividends for years in whlch they have not been declared, the cumulative preferred stock was introduced. What this means is that when directors do declare dividends, cumulatlve preferred shareholders are entitled to their annual dividend for any year in which directors have not declared dividends before common shareholders are entitled to anythlng. For example, assume that a cumulative preferred shareholder is entitled to $\$ 1$ dividend per year. Assume further that directors have not declared dividends for 1968 and 1969 and that in 1970, the directors declare demands in the amounts of $\$ 5$. The preferred shareholder is entitled to the first \$3, $\$ 1$ each for 1968, 1969 and 1970. As Guttman indicates, a non-cumulatlve preferred shareholder is only entitled to $\$ 1$, and the common shareholders, the remaining $\$ 4$. Obviously, only the best companies can market non-cumulative preferred stock. 
Is non-cumulative preferred stock really preferred stock? Doesn't the holder of it take the risks of common withcut the benefits of preferred? As Guttman Illustrates directors mlght not declare dividends for a number of years to the detriment of the non-cumulative preferred shareholder. Is it reasonable to expect that the preferred shareholders understood that they might, in effect, lose their preferred position if the corporation could not pay dividends in a particular year? Even assuming that the preferred shareholders might expect to lose out when the corporation couldn't pay dividends, is It fair to permit the corporation to dellberately refuse to pay dividends when the corporation had sufficient profits?

Should the law "step in" and remedy the situation? Should non-cumulative preferred stock be outlawed?

(2) A position scmewhat different from Guttman has been taken by the courts in New Jersey. See Sanders V. Cuba R.R. Co. 21 N.J. 78, 120 A.2d 849 (1956). "Under the New Jersey view, the board has the discretion to pass a dividend which $\mathrm{mlght}$ have been paid to the non-cumulative preferred shareholders but, If it does, a dividend credit to the extent that the fund was capable of paying such a dividend results. From such dividend credits, dividends in arrears on non-cumulative shares must first be paid before ccmmon shareholders are entitled to any. But earnings which have been retained for corporate uses and upon which there is a 'dividend credit' may be partially or entirely lost in carrying on the business and, if they are, the non-cumulatlve preferred shareholders have no claim upon subsequent earnings to replenish what had prevlously been a dividend credit." $N$. Lattin, The Law of Corporations (1959).

The difference in the two approaches is lllustrated by the following language from Justice Jacob's opinion in Sanders:

It may be acknowledged that New Jersey's dividend credit rule has not generally been accepted by the other states or in the federal courts. See Wabash Rallway Co. v. Barclay, 280 U.S. 197, 50 S.Ct. 106, 74 L.Ed. 368 (1930); Joslin V. Boston Maine R. R., 274 Mass. 551, 175 N.E. 156 (Sup.Jud.Ct.1931); Norwich Water Co. v. Southern R. Co., II Va.L.Reg.N.S. 203 (1925); Note, Dividend Credits for NonCumulative Preferred Stock, 17 U.Chi.L.Pev. 740 (1950); Note, Rights of Preferred Stockholders as to Passed or Accumulated Dividends in Going Concern, 27 A.L.R.2d 1073, 1116 (1953). In the recent case of Guttman v. Illinois Central R. Co., 189 F.2d 927, 930 (2 Cir., 1951), certiorari denied 342 U.S. 867, 72 S.Ct. 107, 96 L.Ed. 652 (1951), Judge Frank expressed the view that nothing in the terms of the ordinary non-cumulative preferred stock contract points to "a contingent or inchoate right to arrears of dividends" and that the contrary notion is an invention "stemmlng from considerations of fairness, from a pollcy of protecting investors in those securitles." There seems to be little doubt that equitable factors did play a significant part in the development of New Jersey's doctrine. In the Wabash Rallway case, supra, Justice Holmes stated that there was a common understanding that dividends which were passed (though there were profits from whlch they could have been declared) were forever gone insofar as non-cumulative preferred 
stock was concerned; but he referred to no supporting materlals and there are those who have suggested a dlametrlcally opposite understanding. See Lattin, Non-Cumulative Preferred Stock, 25 III.L.Rev. 148,157 (1930). This much is quite apparent--if the common stockholders, who generally control the corporation and wlll benefit most by the passing of the dividends on the preferred stock, may freely achleve that result without any dividend credit consequences, then the preferred stockholders wlll be substantlally at the mercy of others who wlll be under temptation to act in their own selfInterest. See Note, Dividend Rights of Non-Cumulative Preferred Stock, 6I Yale L.J. 245, 25I (1952); Note, RIght of Non-Cumulative Preferred Stockholders to Back DIvldends Earned But Unpald, 74 U.Pa.L.Rev. 605, 608 (1926). While such conclusion may sometimes be compelled by the clear contractual arrangements between the partles there is no just reason why our courts should not avold it whenever the contract is sllent or is so general as to leave adequate room for its construction. In any event, New Jersey's doctrine has recelved wide approval in legal writings and there does not seem to be any present disposition in this court to reject it or IImIt its sweep In favor of the Supreme Court's approach In the Wabash Rallway case. See Frey, The DIstribution of Corporate Dividends, 89 U.Pa.L.Rev. 735, 750 (1941); Berle, Non-Cumulative Preferred Stock, 23 Col.L.Rev. 358 (1923); Lattin, supra.

What position is "falrer"?

MABLEY \& CAREW CO. $\checkmark$. BORDEN

129 Ohlo St. 375, 195 N.E. 697 (1935)

Action by Ida C. Borden agalnst the Mabley \& Carew Company. The Court of Appeals reversed a judgment of the Court of Common Pleas for defendant and certifled the case to the Supreme Court for revlew.--[Editorlal statement.]

Judgment of Court of Appeals afflirmed.

Ida C. Borden brought an action in the court of common pleas of Hamilton county against the Mabley \& Carew Ccmpany, alleging in her petition that Anna Work, her slster, now deceased, was and had been for some years an employee of such company and that it promised and agreed in writing to pay to such person as was designated by Anna Work on the back of a certlificate issued to her a sum equal to the wages recelved by her from the company for the year next preceding the date of her death. The plaintiff in error further alleges that she is the person designated on the back of the certificate; that Anna Work continued in the employ of the company untll the date of her death; that her wages for the year preceding were $\$ 780$, and she prays judgment for this amount with interest from the date of the death of Anna Work.

The Mabley \& Carew Company in effect denles these allegations and states affirmatively that if the certificate was issued as claimed, it was 
Issued voluntarl ly and gratultously and without consideration, and was issued to Anna Work and accepted by her with the express understanding that it carried no legal obligation.

A reply was flled, denying the affirmative allegations of this answer. The case came on for trial in the court of common pleas and at the conclusion of the plaintiff's evidence the trial court sustained a motion directing a verdict for the Mabley \& Carew Company.

Motion for new trial was overruled, judgment was entered and error was prosecuted to the Court of Appeals of Hamllton county, which court reversed, set aside and held for naught the judgment of the court of common pleas. The Court of Appeals, finding that its declsion was in conflict with the declsion In the case of Black v. W. S. Tyler Co., 12 Ohlo App. 27, certified the case to this courtifor review and final determination.

The following is a copy of the certificate upon which the action was predicated:

"No. 378.

"The Mabley \& Carew Co.

"To Mrs. Pinna Work.

"In appreclation of the duration and falthful character of your services heretofore rendered as an employee of this Company, there will be paid in the event of your death, if still an employee of this Company, (except under those clrcumstances which would glve rise to an obligation on the State of Ohio under any Workmen's Compensation Act to reimburse your Estate for your death,) to the party or partles designated by you on the back of this certificate a sum equal to the wages you have recelved from this Company for the year next preceding the day of your death, but in no event to exceed the sum of Two Thousand Dollars.

"The issue and dellvery of this certificate is understood to be purely voluntary and gratuitous on the part of this Company and is accepted with the express understanding that it carrles no legal obligation whatsoever or assurance or promise of future employment, and may be withdrawn or discontinued at any time by this Company.

"Cincinnati, Ohio, Dec. 24, 1919."

"The Mabley \& Carew Co.

"Adolph C. Weiss, Secy.

Indorsement:

"The Mabley \& Carew Co. Date,

"Gentlemen:--It is my desire that you make all benefits payable under this Certificate to the following and in the proportions here indicated: Relation to
Name

Mrs. Ida Borden Sister

Address Proportion

"signature......................

48 . 
LeBlond, Morrlssey, Terry \& GIIday and J. Paul McQueen, all of Cinclnnatl, for plalntiff in error.

Jullus R. Samuels, of Cincinnati, for defendant in error.

STEPHENSON, Judge.

It is contended by the Mabley \& Carew Company that there is no proof of the designation of Ida $\mathrm{C}$. Borden as beneficlary under the certificate in question.

The name appears on the back of the certificate and, whlle it is typewritten, it is certainly a sufficient designation, taken in connection with the fact that Anna Work had It in her possession untll her death.

There is just one question in this case, and that is the consideration for the issuance of this certificate. It is true that Anna Work could not malntain an action on this certificate in her IIfetime, as no right of action existed in her favor; but that fact did not prevent it from belng enforceable, after her death, in the hands of Ida $\mathrm{C}$. Borden.

This certlficate was not a pure gratulty on the part of the Mabley \& Carew Company, as there was a provision in the certiflicate to the effect that the payment would not be made in the event of death unless Anna Work was stlll an employee of the company. This was an inducement to Anna Work to continue in the employ of the company. That is not the only consideration, as it is expressed at the outset that the company appreclates the duration and falthful character of the services of the employee theretofore rendered. The employee, by virtue of the issuance of the certificate, had a right to expect that the person nominated by her would, In the event of her death, recelve the amount designated by the certificate. This was certalniy an incentive to remain in the service of the company.

It is not a tenable proposition that, because Anna Work had no enforceable right during her Ilfe, her beneficlary could take no more than she had. We think the learned Court of Appeals was right in holding that Anna Work, by continulng in the service of the company until her death, created a binding obligation upon the company to pay to her designated beneficlary the sum mentioned in the certificate.

It is stated in the certificate: "The issue and dellvery of this certiflcate is understood to be purely voluntary and gratultous on the part of this Company." That was a part of the contract so far as Anna Work was concerned. She had no right that she could possibly assert, as she had to die before the right would ripen in any one.

The case of Zwolanek v. Baker Mfg. Co., 150 Wis. 517, 137 N. W. 769, 44 L. R. A. (N. S.) 1214, Ann. Cas. 1914A, 793, pronounces the law relative to certificates of this character in its true light as we see it. The court there sald, 150 WIs. at page 521 of the opinion, 137 N. W. 769, 772: 

concluded that the defendant had obligated itself to pay death benefits. Can the cases be reconclled?

\section{BOSTON ICE CO. V. POTTER}

123 Mass. 28 (1977)

Contract on an account annexed, for lce sold and dellvered between Aprll 1, 1874, and Aprll 1, 1875. Answer a general denial.

At the trial in the Superlor Court, before wilklnson, J., without a jury, the plalntiff offered evidence tending to show the dellivery of the Ice and Its acceptance and use by the defendant from April 1, 1874, to Aprll 1, 1875, and that the price clalmed In the declaration was the market price. It appeared that the lce was dellivered and used at the defendant's resldence in Boston, and the amount left dally was regulated by the orders recelved there from the defendant's servants; that the defendant, in 1873 , was supplled with I ce by the plaintiff, but, on account of some dissatisfaction with the manner of supply, terminated his contract with it; that the defendant then made a contract with the Cltlzens' lce Company to furnlsh him with Ice; that scme time before AprII, 1874, the Citlzens' Ice Company sold its business to the plaintiff, wlth the prlvilege of supplying lce to its customers. There was some evidence tending to show that the plalntiff gave notice of thls change of business to the defendant, and informed him of Its Intended supply of 1 ce to hIm; but thls was contradlcted on the part of defendant.

The judge found that the defendant recelved no notice from the plaintiff untll after all the lce had been dellvered by It, and that there was no contract of sale between the partles to thls action except what was to be Implled frcm the dellivery of the lce by the plaintlff to the defendant and Its use by $\mathrm{hlm}$; and ruled that the defendant had a right to assume that the ice in question was dellvered by the Cltizens' lce Ccmpany, and that the plaintiff could not malntain this action. The plaintiff alleged exceptions.

ENDICOTT, J. To entitle the plaintiff to recover, it must show scme contract with the defendant. There was no express contract, and upon the facts stated no contract is to be implled. The defendant had taken lce from the plaintiff In 1873, but, on account of some dissatisfaction with the manner of supply, he termi nated his contract, and made a contract for his supply with the Cltizens' Ice Company. The plaintiff afterward dellvered I ce to the defendant for one year without notifylng the defendant, as the presiding judge has found, that it had bought out the business of the Cltizens" Ice Company, untll after the dellvery and consumption of the lce.

The presiding judge has decided that the defendant had a right to assume that the Ice in question was dellvered by the Cltizens' lce Company, and has thereby necessarlly found that the defendant's contract with that company covered the time of the dellivery of the ice.

There was no privity of contract established between the plaintiff and defendant, and without such privity the possession and use of the property will not support an implled assumpsit. HIlls V. Snell, 104 Mass. 173, 177. 
And no presumption of assent can be implled from the reception and use of the ice, because the defendant had no knowledge that it was furnished by the plalntiff, but supposed that he recelved it under the contract made with the Citizens' Ice Company. Of thls change he was entitled to be informed.

A party has a right to select and determine with whom he will contract, and cannot have another person thrust upon him without hls consent. It may be of Importance to hIm who performs the contract, as when he contracts with another to palnt a plcture or write a book, or furnish articles of a partlcular kind, or when he relles upon the character or qualitles of an individual, or has, as in this case, reasons why he does not wish to deal with a particular party. In all these cases, as he may contract with whom he pleases, the sufflclency of hls reasons for so dolng cannot be inquired into. If the defendant, before recelving the lce, or durling its dellvery, had recelved notice of the change, and that the Citizens' Ice Company could no longer perform its contract wlth him, it would then have been his undoubted right to have resclnded the contract and to decline to have it executed by the plaintiff. But thls he was unable to do, because the plaintiff falled to inform him of that whlch he had a right to know. Orcutt v. Nelson, I Gray, 536, 542. WInchester v. Howard, 97 Mass. 303. Hardman v. Booth, I H. \& C. 803. Humble v. Hunter, 12 Q.B. 310. Pobson v. Drummond, $2 \mathrm{~B}$. \& Ad. 303. If he had recelved notice and continued to take the lce as dellvered, a contract would be Implled. Mudge v. Ollver, I Allen, 74. Orcutt v. Nelson, ubl supra. Mitchell v. Lapage, Holt N.P. 253.

There are two English cases very simllar to the case at bar. In Schmalling $v$. Thomlinson, 6 Taunt. 147, a fIrm was employed by the defendants to transport goods to a forelgn market, and transferred the entire employment to the plaintiff, who performed it without the privity of the defendants, and it was held that he could not recover compensation for his services from the defendants.

The case of Boulton v. Jones, 2 H. \& N. 564, was clted by both partles at the argument. There the defendant, who had been in the hablt of dealing with one Brocklehurst, sent a written order to hlm for goods. The plaintiff, who had on the same day bought out the buslness of Brocklehurst, executed the order wl thout glving the defendant notice that the goods were supplled by hlm and not by Brocklehurst. And it was held that the plalntiff could not malntaln an action for the price of the goods against the defendant. It is sald in that case that the defendant had a right of setoff against Brocklehurst, wlth whom he had a running account, and that is alluded to in the op InIon of Baron Bramwell, though the other judges do not mention it.

The fact that a defendant in a particular case has a claim in setoff against the original contracting party shows clearly the injustice of forcling another person upon him. to execute the contract without hls consent, agalnst whom his set-off would not be avallable. But the actual existence of the clalm in set-off cannot be a test to determine that there is no Implled assumpsit or privity between the parties. Nor can the non-existence of a set-off ralse an Implled assumpsit. If there is such a set-off, it is 
sufficient to state that as a reason why the defendant should prevall; but it by no means follows that because it does not exist the plaintiff can maintain his action. The right to maintain an action can never depend upon whether the defendant has or has not a defense to it.

The Implled assumpsit arlses upcn the deallings between the parties to the action, and cannot arise upon the dealings between the defendant and the orlginal contractor, to which the plaintiff was not a party. At the same tIme, the fact that the right of set-off against the original contractor could not, under any clrcumstances, be avalled of in an action brought upon the contract by the person to whom it was transferred and who executed it, shows that there is no privity between the parties in regard to the subject matter of this action.

It is, therefore, Immaterlal that the defendant had no claim in setoff against the Cltizens' Ice Company.

We are not called upon to determl ne what other remedy the plaintiff has, or what would be the rights of the partles if the ice were now in existence.

Exceptions overruled.

KLORS, INC. $V$. BROADWAY-HALE STORES, INC. 359 U.S. 207 (1959)

Mr. Justice BLACK dellvered the op Inlon of the Court.

Klor's, Inc., operates a retall store on MIssion Street, San Franclsco, Callfornla; Broadway-Hale Stores, Inc., a chaln of department stores, operates one of its stores next door. The two stores compete in the sale of radios, television sets, refrigerators and other household appliances. Clalming that Broadway-Hale and 10 natlonal manufacturers and their distributors have conspired to restrain and monopolize commerce in violation of $\xi \xi 1$ and 2 of the Sherman Act, 26 Stat. 209, as amended, 15 U.S.C.

\$ 1,2 , 15 U.S.C.A. $\xi \xi 1,2$, Klor's brought this action for treble damages and injunction in the United States District Court.

1. Section 1 of the Sherman Act provides: "Every contract, comblnation in the form of trust or otherwise, or consplracy, in restraint of trade or commerce among the several states, or with forelgn nations, is declared to be lllegal * * *." Section 2 of the Act reads, "Every person who shall monopollze, or attempt to monopollze, or comblne or consplre with any other person or persons to monopollze any part of the trade or commerce among the several states, or with forelgn nations, shall be deemed gullty of a misdemeanor ***." Section 4 of the Clayton Act, 28 Stat. 731 , 15 U.S.C. $\$ 15,15$ U.S.C.A. 5 15, states, "Any person who shall be injured in his business or property by reason of anything forbldden in the antitrust laws may sue therefor * * * and shall recover threefold the damages by him sustalned * * *." 
In support of Its clalm Klor's made the following allegations: George Klor started an appllance store some years before 1952 and has operated it ever since either Individually or as Klor's, Inc. Klor's is as well equipped as Broadway-Hale to handle all brands of appllances. Nevertheless, manufacturers and distributors of such well-known brands as General Electric, RCA, Admiral, Zenith, Emerson and others have consplred among themselves and with Broadway-Hale elther not to sell to Klor's or to sell to It only at discriminatory prices and highly unfavorable terms. Broadway-Hale has used its "monopolistic" buying power to bring about this situation. The business of manufacturing, distributing and selling household appliances is in Interstate commerce. The concerted refusal to deal with Klor's has seriously handlcapped its ablility to compete and has already caused it a great loss of profits, goodwlll, reputation and prestige.

The defendants did not dispute these al legations, but sought summary judgment and dismissal of the complaint for fallure to state a cause of action. They submitted unchallenged affidavits which showed that there were hundreds of other household appliance retallers, some within a few blocks of Klor's who sold many competIng brands of appllances, Including those the defendants refused to sell to Klor's. From the allegations of the complaint, and from the affidavits supporting the motion for summary judgment, the District Court concluded that the controversy was a "purely private quarrel" between Klor's and Broadway-Hale, which did not amount to a "publlc wrong proscrlbed by the [Sherman] Act." On this ground the complaint was dismissed and summary judgment was entered for the defendants. The Court of Appeals for the Ninth CIrcult afflrmed the summary judgment. 255 F.2d 21.4. It stated that "a vlolation of the Sherman Act requlres conduct of defendants by whlch the publlc is or concelvably may be ultimately injured." 255 F.2d at page 233. It held that here the requlred public injury was missing since "There was no charge or proof that by any act of defendants the price, quantity, or quality offered the publlic was affected, nor that there was any intent or purpose to effect a change in, or an influence on, prices, quantity, or quallty ***." Id., at page 230. The holding, if correct, means that unless the opportunities for customers to buy in a competitlve market are reduced, a group of powerfui businessmen may act in concert to deprlve a single merchant, Il ke Klor, of the goods he needs to compete effectively. We granted certlorarl to consider this important question in the Administration of the Sherman Act. 358 U.S. 809, 79 S.Ct. 23,3 L.Ed.2d 54.

We think Klor's allegations clearly show one type of trade restraint and public harm the Sherman Act forblds, and that defendants' affldavits provide no defense to the charges. Section I of the Sherman Act makes illegal any contract, combination or conspiracy in restraint of trade, and $\$ 2$ forbids any person or combination from monopolizing or attempting to monopolize any part of interstate commerce. In the landmark case of Standard 011 Co. of New Jersey v. United States, 221 U.S. I, 31 S.Ct. 502, 55 L.Ed. 619 , this Court read $\$ 1$ to prohlbit those classes of contracts or acts which the common law had deemed to be undue restraints of trade and those which new times and economic conditions would make unreasonable. Id., at pages 59-60, 31 S.C . at pages 515-516. The Court construed $s 2$ as making "the prohibltions of the act all the more complete and perfect 
by embracling all attempts to reach the end prohlbited by the Ist section, that is, restraints of trade, by any attempt to monopollze, or monopollzation thereof***." 1d., at page 61,31 S.Ct. at page 516. The effect of both sections, the court sald, was to adopt the common-law proscription of all "contracts or acts whlch It was consldered had a monopollstic tendency * * * " and which Interfered with the "natural flow" of an appreclable amount of Interstate commerce. Id., at pages 57, 61, 31 S.Ct. at page 514; Eastern States Retall Lumber Dealers' Ass'n v. United States, 234 U.S. 600, 609, 34 S.Ct. 951, 953, 58 L.Ed. 1490. The Court recognl zed that there were some agreements whose valldity depended on the surrounding clrcumstances. It emphaslzed, however, that there were classes of restralnts whlch from thelr "nature or character" were unduly restrlctlve, and hence forbldden by both the common law and the statute. 221 U.S. at pages 58, 65, 31 S.Ct. at page 515. As to these classes of restralnts, the Court noted, Congress had determined its own criterla of public harm and It was not for the courts to declde whether in an Individual case Injury had actually occurred. Id., at pages 63-68, 31 S.Ct. at pages 517-518-519.

Group boycotts, or concerted refusals by traders to deal with other traders, have long been held to be In the forbldden category. They have not been saved by allegatlons that they were reasonable in the speclflc clrcumstances, nor by a fallure to show that they "flxed or regulated prices, parcelled out or IImIted production, or brought about a deterloration in quality." Fashlon OrlgInators' Gulld v. Federal Trade Commlsslon, 312 U.S. 457, 466, 467-468, 61 S.Ct. 703, 707, 85 L.Ed. 949. Cf. UnIted States v. Trenton Potterles Co., 273 U.S. 392, 47 S.Ct. 377, 71 L.Ed. 700. Even when they operated to lower prlces or temporarlly to stimulate competItion they were banned. For, as this Court sald In Klefer-Stewart Co. v. Joseph E. Seagram \& Sons, 340 U.S. $211,213,71$ S.Ct. 259, 260, 95 L.Ed. 219 , "such agreements, no less than those to flx minlmum prlces, crlpple the freedom of traders and thereby restraln thelr abllity to sell in accordance with thelr own Judgment." Cf. Unlted States v. Patten, 226 U.S. 525, 542, 33 S.Ct. 141, 145, 57 L.Ed. 333.

Plalnly the allegations of this complalnt disclose such a boycott. This is not a case of a single trader refusing to deal with another, nor even of a manufacturer and a dealer agreelng to an exclusive distributorshlp. Alleged in this complalnt is a wide comblnation conslsting of manufacturers, distrlbutors and a retaller. Thls ccmbl natlon takes from Klor's Its freedom to buy appllances in an open competitive market and drives it out of buslness as a dealer in the defendants' products. It deprlves the manufacturers and distrlbutors of thelr freedom to sell to Klor's at the same prlces and conditlons made avallable to Broadway-Hale and In scme Instances forbids them from selling to It on any terms whatsoever. It interferes with the natural flow of Interstate commerce. It clearly has, by Its "nature" and "character," a "monopollstic tendency." As such It is not to be tolerated merely because the victim is just one merchant whose business is so small that hls destruction makes little difference to the economy. Monopoly can as surely thrive by the ellmination of such small businessmen, one at a tIme, as it can by driving them out in large groups. In recognition of thls fact the Sherman Act has consistently been read to forbid all contracts and comblnatlons "whlch "tend to create a 
monopoly," whether "the tendency is a creeplng one" or "one that proceeds at full gallop." Internatlonal Salt Co. v. United States, 332 U.S. 392, 396,68 S.Ct. 12, 15, 92 L.Ed. 20:

The Judgment of the Court of Appeals Is reversed and the cause Is remanded to the DIstrict Court for trlal.

Reversed.

\section{NOTES}

The following excerpt from Note, Proving Injury to Competition In Private Antitrust Sults Provoked by Concerted Refusals to Deal, 68 Yale L.J. 940-55 (1959), brlefly descrlbes the backiground of the Klor's case:

To win a private antitrust sult, the Individual competitor who brlngs one must demonstrate that hls Injury was occasloned by an Injury to competition. A simllar rule applles when the Government sues on account of harm to a competitor, but injury to competItIon is then more readlly establl shed, for federal agencles ordinarlly contest only those practices which are felt throughout a glven market. A private clalmant, on the other hand, is tempted to assert that an injury to hIm is of Itself sufficlently harmful to competition to violate the antitrust statutes; should the assertIon stand, he would come wlthin section 4 of the Clayton Act, whlch provldes that "any person who shall be Injured In his buslness or property by reason of anything forbldden in the antltrust laws" may recover treble damages frcm the person violating the laws. The courts, however, have long been hostlle to clalms whlch would turn this section into a vehicle for redressing tortlous business practices. At one time, a section 4 complaint was considered defectlve If It falled to allege "publlc Injury" In addition to private loss. Although this formallsm is no longer a prerequisite to a treble-damage sult, the courts continue to vlew antitrust leglslation as designed exclusively to protect markets from "undue $\mid \mathrm{lml}$ tations on competitive conditions"--and not as a safeguard agalnst Indlvidual, economlc loss. Prlvate recovery follows only upon a showling that damage to the plaintiff proximately resulted from such statutory Infractions as prlce-fIxIng, tylng agreements, and unreasonable restrlctions on market entry. Also open to attack are attempts at monopollzation and restralnts tending to modify the competitive characterlstics of a market.

One buslness practice whlch frequently provokes prlvate antitrust action is denylng a trader access to his customers or suppliers. When such denlal results from the Independent, unllateral action of Individual customers or suppllers, the antitrust laws generally countenance the consequences on the theory that a single entrepreneur, acting alone, may fashlon hls buslness relatlonshlps as he sees fit. When, however, a refusal to deal is undertaken by a group of competitors acting in concert to coerce a trader, the courts are qulck to outlaw the refusal. Supreme Court dlctum has 
categorlzed boycotts of thls type as IIlegal per se, and declsional Iaw condemns them wIth IIttle examInation of thelr purpose or antIcompetItlve effects. At a mInImum, concerted refusals to deal are prima facle Illegal and can be justifled only if Intended to achleve ends unconnected with antitrust pollcy. Thls antipathy toward group boycotts springs in part from the vlew that antitrust leglslation seeks to promote free access to markets, and in part from the conclusion that any effectlve boycott, by artiflclally controlling market structure, tends to usurp governmental functions or to create a monopoly for the boycotting partles. In virtually all of the reported cases, additional elements may also have Influenced the declslons. Typlcally, the boycottling group wlelded substantlal market power, and the persons harmed constltuted elther a large group of producers whose dutput, if restrlcted, would affect prices, or an open-end class of competitors who had refused or mlght refuse to comply with the boycotters demands. Thus, until recently, the courts had not passed on a concerted refusal to deal dl rected agalnst a single trader so small that hIs ellmination would not in Itself affect market prlce.

A group boycoft agalnst a single trader may well underlle the section 4 case of Klor's Inc. V. Broadway-Hale Stores, Inc., now before the federal courts. Plalntiff Klor's Is a small retall outlet In the MIssion DIstrlct of San Francisco; defendant Broadway-Hale owns a chaln of department stores one of whlch adjolns Klor's. The complalnt alleged that Broadway-Hale had Induced the other defendants--ten leading radlo, television and appllance manufacturers and thelr reglonal distrlbutors--not to sell thelr products to KIor's. Accordling to a further allegatlon, BroadwayHale purchases such a great volume of these products that $1+$ enjoys sufflclent ollgopsonistlc power to cause the manufacturers to boycott Klor's on paln of losing Broadway-Hale's buslness. WIthout denyling these al legatlons, the defendants moved for summary judgment upon affldavlts showling that KIor's could stIII satisfy Its requlrements by buylng from other manufacturers; that many hundreds of retall dealers sell app Ilances In the San Franclsco area; and that, In the MIssion DIstrict alone, over flfty retall outlets carry the products of the defendant manufacturers.

The distrlct court, In granting summary judgment for defendants, characterlzed the complalnt as evidenclng "purely a prlvate quarrei" which does not glve rise to a cause of actlon under the antitrust laws. [1956 Trade Cas. 72048 (N.D. Cal.).] On appeal, the Ninth Clrcult affirmed. [255 F.20 214 (9th Clr. 1958) ] it reasoned that treble-damage actions serve to Implement antltrust pollcy, and that, while an allegatlon of "publle Injury" is no longer vital to a private complalnt, "the purpose of the antitrust statutes is to protect the 'pubflic' from the harm whlch follows frcm concerted or monopolistic conduct designed to acqulre control of a market, usually competitive, to whlch the publlc must ultimately resort. . ." Turning to the alleged unlawful restralnt, the court held that the refusals to deal were not per se lllegal because the defendants 
nelther attempted to secure monopoly power nor sought to control prices. The court further ruled that a boycott could not be deemed to restrain trade unreasonably absent a "charge or proof that by any act of defendants the prlce, quantity, or quallty [of goods] offered the public was affected." And the large number of substitute retall outlets aval lable to consumers Indlcated that "there has been no conduct by whleh the 'public' could concelvably suffer Injury. ..."

THREET, JustIce.

Appel lant brought a sult number 6244 on the clvil docket of the DIstrict Court within and for Mckinley County, New Mexico, to revive a judgment theretofore entered by that court In cause No. 4959. By a trial amendment, appel lee Interposed the defense that the judgment in cause No, 4959, being based upon a promlssory note contalning cognovit provislons in contravention of 1941 Comp., Secs. 19-916 and 19-918, is vold.

The findings of fact and conclusions of law made by the trlal court are to be found in the judgment as follows, to-wit:

"That on the 26th day of May, 1943, In cause No. 6244 in the DIstrict Court of the County of McKinley, State of New Mexico, the plaintiff R. C. RItchey flled a complalnt agalnst the defendant E. J. Gerard for the purpose of renewling and reviving a judgment heretofore entered on the 3rd day of June, 1935, In cause No. 4959 of the Distrlct Court within and for the county of McKInley and State of New Mexico;

"That the judgment sought to be revived was based upon a certaln complalnt flled in cause No. 4959 on the 29th day of Aprll, 1935, whereln the plaintiff recovered Judgment from the defendant on a certain promlssory note dated January 27th, 1934; and that sald note upon whlch judgment was obtalned was a cognovit note;

"That In sald cause No. 4959 a summons was duly Issued and served upon the defendant E. J. Gerard, who, however, falled to appear or otherwise answer sald complaint in the time requlred by law, and judgment was obtalned agalnst hIm by default.

"From the facts so' found, the Court concludes as a matter of law:

"I. That the Court has jurisdiction of thls cause and the partles to this action;

"2. That cause 6244, whlch is an action to revive the judgment heretofore found for the plaintiff, being based upon an action orlginally upon a cognovlt note, should be dismissed; 
"3. That the judgment entered in cause 4959, belng based upon a cognovit note, is vold and of no force and effect."

Based upon the foregolng findings of fact and conclusions of law, the trial court entered its judgment declaring the judgment in cause No. 4959 null and vold and dismlssing appellant's cause of action No. 6244.

From this judgment appellant appeals, assigning error. Polnts relled upon by appellant for reversal of this case are as follows:

"I. The court erred In concluding that an action to revive a judgment originally based upon a cognovit note should be dismissed.

"2. The court erred In declaring the judgment rendered In cause No. 4959 , belng based upon a cognovit note, vold."

The question here Is, does the Inclusion In a promissory note of a cognovit provision, which is declared to be unlawful under the statutes of New Mexlco, make vold the entire contract?

Sections 19-916 and 19-918, supra, are respectively as follows:

"It shall be unlawful to execute or procure to be executed as part of or In connection with the execution of any negotlable instrument, or other written contract to pay money, and before a cause of action thereon shall have accrued, any contract, agreement, provision or stipulation giving to any person or persons a power of attorney or authority as attorney for the maker or endorser thereof, In his name to appear in any court of record, and walve the service of process in an actlon to enforce payment of money clalmed to be due thereon, or authorlzing or purporting to authorize an attorney or agent, howsoever designated, to confess judgment on such instrument for a sum of money to be ascertalned in a manner other than by action of the court upon a hearing after notlce to the debtor, whether with or without an attorney fee, or authorizing or purporting to authorlze any such attorney to release errors and the right of appealling from such judgment, or to consent to the issue of execution on such judgment. Any and all provisions herelnabove declared to be unlawful, contalned in any contract, stipulation or power of attorney given or entered into before a cause of action on such promlse to pay, shall have accrued, shall be vold."

"Any negotlable Instrument, or other written contract to pay money, which contalns any provision or stipulation giving to any person any power of attorney, or authorlty as attorney, for the maker, or any endorser, or assignor, or other person Ilable thereon, and in the name of such maker endorser, assignor, or other obllgor to appear in any court, whether of record or Inferlor, or to walve the issuance or personal service of process in any action to enforce payment of the money, or any part clalmed to be due thereon, or whlch contains any provision or stipulation authorizing or purporting to authorlze an attorney, agent or other representative be he designated howsoever, to confess judgment on such instrument for a sum of money when such sum is to be ascertalned, or such judgment is to be rendered or entered otherwise than by action of court upon a hearlng after personal 
servlce upon the debtor, whether with or without attorney's fee, or whlch contalns any provision or stipulation authorlzing or purporting to authorize any such attorney, agent, or representative to release errors, or the right of appeal from any judgment thereon, or consenting to the Issuance of execution on such judgment, is hereby designated, defined and declared to bo a cognovit note. Any person, natural or corporate, who di rectly or Ind rectly shall procure another, or others, to execute as maker, or to endorse, or assign such cognovit note, or whoever belng the payee, endorsee, or assignee thereof shall accept and retaln in hls possession any such instrument, or whoever shall consplre or confederate with another, or others, for the purpose of procuring the execution, endorsement or assignment of any such instrument, or whoever shall attempt to recover upon or enforce within this state any judgment obtalned in any other state or forelgn country based upon any such instrument, shall be deemed gullty of a misdemeanor and upon conviction shall be fined in any sum not less than flfty dollars $(\$ 50.00)$, and not exceedling flve hundred dollars $(\$ 500.00)$, to whlch may be added imprisonment for not less than thirty (30) days."

These sections were apparently taken from Chapters 66 and 227 of the 1927 Session Laws of the State of Indlana, whlch appear In Burns' Code as Sectlons 2-2904 and 2 2906 , as they are In the exact language of the Indiana statute, except the last sentence in Sec. 19-916, supra, and the last sentence In Sec. 2-2904, supra, whlch read respectively as follows:

"Any and all provislons hereinabove declared to be unlawful, contalned in any contract, stipulation or power of attorney glven or entered into before a cause of action on such promise to pay, shall have accrued, shall be vold."

"Any and all contracts, stlpulations and powers of attorney given or entered Into before a cause of action on such promise to pay, shall have accrued, shall be vold."

The statutes of the State of Indlana have been construed by the courts of that State on several occasions. The last expression is to be found in SImpson et al. v. Fuller, Ind.App., 51 N.E.2d 870, 872. In this case appellants brought sult to recover upon a conditlonal sales contract whlch contalned a cognovlt clause as deflned by the laws of that state. Appellees demurred to the complalnt on the ground that the contract contalned a connovit clause and was therefore vold and unenforceable, as being in vlolatlon of the sections of the Indlana Code, supra. The trlal court sustalned the demurrer and dIsmissed appellants' complalnt. Upon appeal the Appellate Court of Indlana sald:

"Section 2-2906, Burns" (Sec, 398, Baldwln's), Is a penal statute and should be construed as such. Under it instruments containing cognovit provisions are not declared vold by express terms. The statute merely defines a misdemeanor and prescrlbes a penalty therefor. It must be construed strlctly and cannot be extended or enlarged beyond its express provisions. 
"Nor does 1t appear that Section 2-2904, Burns' (Sec. 399, Baldwln's), is Intended to make vold entlre contracts containing, among other provisions, cognovit clauses. It only is intended to make vold contract provisions glving power of attorney with authorlty to confess judgment on such instrument for a sum of money to be ascertalned In a manner other than by action of the court upon a hearing after notice to the debtor. A study of this section Impresses us that the purpose and Intent of the legislature as thereby and thereln expressed is to prevent judgments from belng obtalned without notlce or service of process by virtue of a power or authorlty executed prlor to the accrual of a cause of actlon.

"In the Instant case we are confronted wIth a contract contalning, In addition to the cognovit clause, several provislons and agreements, all of them wholly within the law. Does the Inclusion thereln of the cognovit clause make vold the entlre contract? We think not. Where an agreement founded on a legal consideration contalns several promises, or a promise to do several thlngs, and a part only of the things to be done are llllegal, the promlses which can be separated, or the promlse, so far as $1+$ can be separated, from the Illegallty, may be valld. Thus, where a contract is made up of several covenants and agreements, and one covenant is IIlegal, If the Illegal covenant can be ellminated without destroylng the symmetry of the contract as a whole, the courts wlll do so and enforce the remalinder. Jordan v. KIttle, 1928, 88 Ind.App. 275, 150 N.E. 817.

"In the Instant case the cognovit clause In the contract under consideration is separable without in any wise affecting the remalnder of the contract. Nor did appellants attempt to act under the cognovit provision. From the record It appears that appellants flled thelr complaint in due form and process issued thereon. From the showlng of the complaint appellee Is Indebted to appellants on a contract and appellants seek rellef in a manner wholly legal.

"Appellee's demurrer to the second paragraph of complalnt should have been overruled. Other questions here presented are fully resolved by the foregolng oplnion.

Appel lee argues that the note In cause No. 4959, belng in direct contravention and In vlolation of Sec. 19-918, supra, was vold and of no effect, and the judgment based thereon also is vold and of no force and effect. This argument would carry much welght if we were here deallng on ly with Sec. 19-918, supra. In ThIrd Natlonal Exchange Bank of Sandusky Ohlo et al. v. D. B. Smith et ux., 17 N.M. 166, 125 P. 632, 635, we sald:

"We think the authorlties unlformly hold that an act done In vlolation of a statutory prohlbition is vold, and confers no rlght upon the wrongdoer."

We also recognlzed in the same case an exception to this rule:

"We are aware that the rule above stated is subject to the quallficatIon that when upon a survey of the statute and from Its subject-matter. 
and the mlschlef sought to be prevented, It appears that the Leglslature Intended that the violation of the statutory prohlbition should not render a contract vold, effect must be given to that Intention * * *."

See, also, Delgado et al. v. Colgado, 42 N.M. 582, 82 P.2d 909, 118 A.L.R. II75.

To arrlve at the true legislative Intent the two Sectlons, viz.: 19-916 and 19-918, supra, must be construed together. Sec. 19-918 is a criminal statute and should be construed as such. Under It a promlssory note or other Instruments contalning cognovit provislons are not declared vold by express terms. This section of the statute defines a cognovit note and makes $1+$ a mlsdemeanor for any person, natural or corporate to deal with such notes as follows:

"Any person, natural or corporate, who directly or Ind I rectly shall procure another, or others, to execute as maker, or to endorse, or assign such cognovlt note, or whoever belng the payee, endorsee, or assignee thereof shall accept and retain in hls possession any such Instrument, or whoever shall consplre or confederate wlth another, or others, for the purpose of procurling the execution, endorsement or assignment of any such Instrument, or whoever shall attempt to recover upon or enforce within this state any judgment obtalned in any other state or forelgn country based upon any such. Instrument, shall be deemed gullty of a misdemeanor and upon conviction shall be flned In any sum not less than flfty dollars $(\$ 50.00)$, and not exceedling five hundred dollars $(\$ 500.00)$, to whlch may be added Imprisonment for not less than thI rty (30) days."

Section 19-916, supra, does not make vold the entire contract contalrIng, among other provlsions, cognovlt clauses. It is manlfest by referring to the last sentence of that section, that it is only Intended to make vold the provislons glving power of attorney with authorlty to confess judgment on such Instruments for a sum of money to be ascertalned. In a manner cther than by action of the court upon a hearlng after proper service of process. A study of thls section loads us to the conclusion that the purpose and Intent of the leglslature, as thereln expressed, is to prevent judgment from belng obtalned without notlce or service of process by virtue of a power of attorney executed prlor to the accrual of the cause of action.

In the case at bar the note, upon which the judgment in cause No. 4959 was based; contalned In addition to the cognovlt clause other provisions legal In every respect. Does the Inclusion therein of the cognovit clause make vold the entire note? We think not. In simpson $v$. Fuller, supra, and Jordan v. Kittle, 88 Ind.App. 275, 150 N.E. 817 , it is sald:

"Where an agreement founded on a legal conslderation contalns several promises, or a promise to do several things, and a part only of the things to be done are Illegal, the promises whlch can be separated, or the promlse, so far as It can be separated, from the Illegallty, may be valld. Thus, where a contract is made up of several covenants and agreements, and one covenant is IIlegal, If the IIlegal covenant can be el ImI nated without destroylng the symmetry of the contract as a whole, the courts wlll do so and enforce the remalnder." 
In the Instant case the cognovit clause In the note is separable without In any wise affecting the remalnder of the note and the obIIgation of appellee to pay. It is admitted by appellee, and the trlal court so found, that the appellant did not attempt to procure a judgment by virtue of the cognovit clause in the note. It appears from the findings of the trlal court that In cause No. 4959, appellants flled thelr complaint and summons was duly Issued and served on appellee, who falled to appear or answer with In the tIme requl red by law and judgment was rendered agalnst him by default. There is no contentlon that appellee was not Indebted to appellant upon the note in sult In cause No. 4959, and it affIrmatively appears that appellant obtal ned Judgment upon sald note in a legal manner and as provlded by law.

It is Interesting to note that the Indlana statute is more susceptible to the construction contended for by appellee than Sec. 19-916, supra, of the New Moxico laws. The Indlana statute declares that any and all contracts, stipulations and powers of attorney given or entered into before the cause of action shall have accrued, shall be vold. Under Sec. 19-916, supra, It Is provlded that any and all provislons declared unlawful, contalned in a contract given or entered into before the cause of action shall have accrued, shall be vold; yet the construction placed upon the Indlana statute by the Courts of that State, as to the Intent and purpose of the leglslature, was to make vold only those provlslons in a contract which provlde for judgment without notice or service of process by virtue of the power or authorlty executed prior to the accrual of the cause of action.

The trlal court was In error In declaring the judgment In cause No. 4959 vold and dIsmlssing appellant's cause of actlon.

The judgment wlll be reversed. The cause wlll be remanded with directlons to set aslde the judgment, and proceed with the cause not Inconsistent herewith. It is so ordered.

SADLER, C. J., and MABRY, BICKLEY, and BRICE, JJ., concur.

\section{NOTES}

(1) It is a general rule that a contract whlch purpose is to violate some rule of law or publlc pollcy is itself IIlegal and therefore vold. Section 512 of the Restatement of Contracts defines the "lllegal bargain" as "a bargaln . . . [whlch] formation or Its performance is criminal, tortlous, or otherwlse opposed to publlc pollcy." Wagering agreements and bribery agreements are obvlous examples of this rule.

Does Rltchey v. Gerard fall squarely wlthin the meaning of this defl$\mathrm{nlti}$ ion? Why has the cognovit clause been outlawed In New Mexlco and many other states? 
WOLF V. MARLTON CORP.

57 N.J. Super. 278, 154 A.2d 625 (App.DIV. 1959)

FREUND, J.A.D.

Plaintiffs, husband and ife, Instituted this action In the Camden County Court to recover a deposit of $\$ 2,450$ whlch they mad under a contract to purchase a house to be bullt for them by the defendant, The Mariton corporation. The sale was never consummated, and the defendant bullider eventually sold to a thlrd party the home whlch had been Intended for the Wolfs. The theory of the actlon is that plalntiffs were at all times ready, wllling, and able to comply wlth the bullding contract but that the bullder unllaterally and unjustlflably terml nated the contract wlthout returning the down payment. The County Court judge, slttling without a jury, concluded in a written op Inlon that It was the defendant who refused to perform under the contract and that consequently a judgment in favor of plaintiffs was dictated. The Marlton Corporation (herelnafter "the bullder") appeals.

The agreement of sale, entered Into by the partles on March 8, 1957, called for the constructlon of a dwelling In defendant's housing development In Haddon Townshlp upon the followling terms:

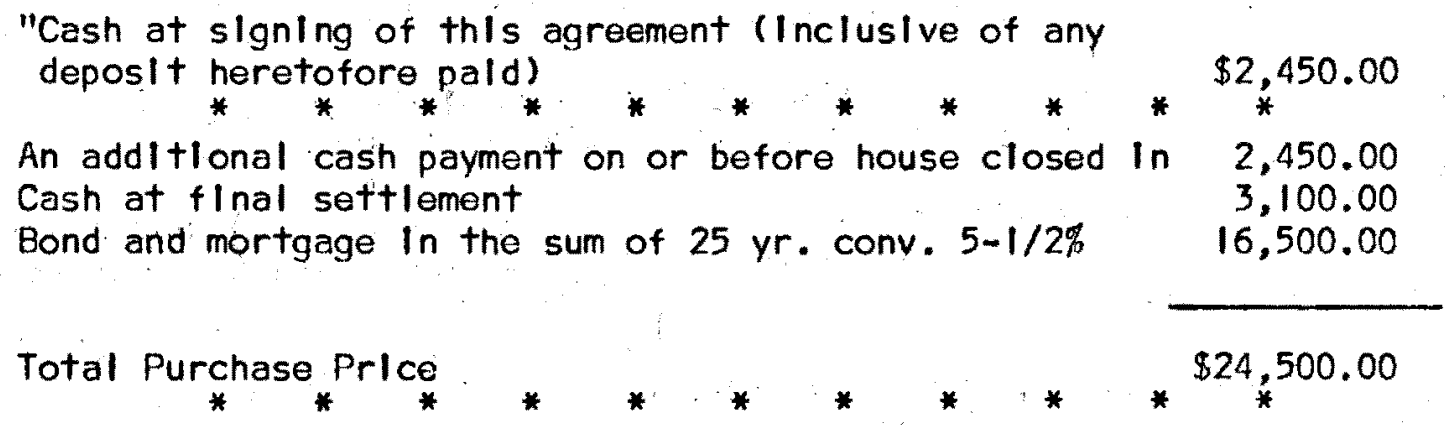

"Should Buyer fall to make payment of any addltional moneys as hereln mentloned, or fall to make settlement as hereln provided, the sum or sums pald on account may be retalned by Seller elther on account of the purchase prlce or as compensation for the charges and expenses which Seller has sustalned, as Seller may elect, In whlch latter case thls contract shall become nuil and vold and all coples hereon shall be returned to the Seller for cancellation."

It Is undisputed that the bullder had completed the "closina In" of the house scmetime in June 1957 and that plaintiffs did not make the second payment. Thelr fallure in this respect is attrlbuted to the conceded fact that they were never personally notlfled by the bullder that the house had been "closed in." After reviewing the testimony, the trlal judge stated in his op Inlon that the case presented a "simple question" as to whether "the plalntiffs were entitled to a notlce that the house was closed in or whether the defendant, wlthout glving such notice, could clalm a default * * *." He concluded that the agreement of sale contemplated the glving of such notlce. Defendant does not, on appeal, challenge this portion of the opinion below... 
The alternatlve ground brlefed on behalf of the bullder as basls for a reversal flxes upon a matter of far greater Import. The polnt is captloned: "Buyers breached the agreement of sale by preventing its performance through threats to resell the house to an undesirable purchaser and to ruin defendants" bullding buslness if defendants carrled out the contract."

The factual basis for the argument ralsed is not developed systematically in the brlefs. As to those events whlch contrlbuted to a mutual unwlllingness to perform the contract, we are compelled to reconstruct them plecemeal from the briefs, the opinion of the trial judge, and such portions of the testimony the appellant has seen fit to submit. It appears that the eventual collapse of negotlations had its genesis in maritai difficulties between the plaintiffs experienced in the summer of 1957. Apparently because of this, plaintiffs instructed their attorney that they would like to get out of the agreement of sale. The attorney in turn informed defendant's sales agent, Irving Gitomer, that there were "certain problems here," and that plalntiffs would llke "to get the money back."

Mr. Gitomer testlfled that he spoke with plaintlffs' attorney on at least three occaslons during July and August of 1957. In one such conversation, the attorney told him the Wolfs were ready, wllling and able to purchase the home, even if the terms were cash, but, as Mr. Gitomer testifled:

"[T]his conversation was coupled with the fact that they were reluctant to do it, but, if they had to do it, they would go through with the sale, and that a subsequent resale would be arranged to a purchaser who would be undesirable in our tract, and that we would not be happy with the results."

Martin Fleld had but one telephone conversation with plalntiffs' attorney, which was in the second week of September. The two discussed the possibllity of a settlement, Field agreeing to honor the request for cancellation if defendant were allowed to retain $\$ 1,000$ of the $\$ 2,450$ deposit. Field testified as to what then ensued:

"[H]e reiterated in very strong and clear terms that if we did not accept hls offer [of \$450] it would be the sorriest move that I ever made In my building career. I accepted it as a threat, and I felt that at this point it was imposslble to go ahead and continue with this thing. The threat was made in the terms that, "It's all right. If you are going to force us-you have got us over a barrel, and, If you are going to force us to make this settlement, we will make the settlement, but It wlll be the last settlement that you "II ever make, and it will be the last tract that you will ever build in New Jersey, and it wlll be the last house that you will sell in this tract, and he continued, he named a few of the attorneys who lived in the tract, and said, 'Don't have the fellows who live in your tract tell me I shouldn't do it. It doesn't make any difference to me. I'm telling you what $1^{\prime} \mathrm{m}$ going to do. I'm going to do it, and It will be the sorriest thing that you have ever done." At 
this point, although I had offered to refund $\$ 1,450.00$, It became apparent that he was using this as leverage to drive us down to the $\$ 450.00$ figure, and I told him no, that we wouldn't do it, and that's where the thing was left."

The first question asked of fleld on cross-examination was:

"Despite this conversation of whlch you speak, Mr. Field, you never notifled the people to come to a settlement or closing of this thing, did you?"

He replled:

"I wesn't going to make a closing after someone threatened to ruin my bullding career."

Subsequently, by letter of December 30, 1957, the bullder's counsel advised the attorney that by reason of plaintiffs' "materlal breach" of the contract, it had become "null and void" and that defendant would retain the down payment. The letter assigned as the cause of termination, "among other reasons," plaintiffs' failure to make the second payment. At the oral argument defense counsel (pro hac vice), who had propared this letter for the bullder, stated that he had advisedly used the phrase "among other reasons" because he did not deem it discreet to make written reference to the threat that had actually been made and to whlch Field testlitled.

Based upon this letter, which plaintiffs malntain constituted the first breach of contract, suit was instituted for the recovery of the deposit.

We have already stated the basis upon which the county Court entered judgment in favor of the plaintiffs. But contrary to the assertion in plaintiffs' brief that the court found as a fact that the bullder's refusal to consummate the sale was not justlfied by any threats, we do not read the opinion below as reaching any express determination on whether the threats, assuming they were made, justified the bullder in declaring a breach and refusing further performance. The court clted what it called "the so called threat"--not in relation to whether there existed any justification for the bullder's course of conduct, but rather to indicate that the builder was admlttedly unwllling to perform under the contract and therefore would not be heard to contend plaintiffs should have made the second payment; the question of justification for the bullider's action in rescinding seems not to have been adjudged. Moreover, even if the opinion is to be construed as containing an implled determination on the issue, we do not conceive that such would be a finding of fact, as distingulshed from the determination of a legal issue. Whether duress exists in a particular transaction is generally a matter of fact, but what in given circumstances wlll constitute duress is a matter of law. Accordingly, the scope of appel late inquiry as to the correctness of the trial result is not so limited as plaintlffs suggest.

It is clear that where one party to a contract, by prevention or hindrance, makes it impossible for the other to carry out the terms thereof,

66. 
the latter may regard the contract as breached and recover $h$ is damages thereunder from the first party. Tanenbaum v. Francisco, 110 N.J.L. 599, 604-605, 166 A. 105 (E. \& A. 1933); Hanig v. Orton, 119 N.J.L. 248, 252, 195 A. 812 (Sup.Ct. 1938); 4 Corbln, Contracts (1951), \$ 947, p. 813. It is also clear that if the performance is prevented by physical threats, the threatened party may deslst from performing, treat the contract as breached, and recover damages. He need not seek police protection or a judicial order to shield $\mathrm{hlm}$ in his performance of the contract. Kroop $v$. Scala, 5 N.J.Misc. 89, 135 A. 501 (Sup.Ct. 1927). The bullder directs our attention to the last-cited case in particular. There a house owner had threatened a painting contractor that "If he went into the house to work he would cut his head off." 5 N.J.Misc. at page 90, $135 \mathrm{~A}$. at page 501 . The court held the contractor was entitled to terminate the contract and to recover his profits; he was not obliged to run the risk that the owner would carry out his threats. Defendant urges that, except for the degree of sophistication, there is no real difference between a threat to cut one's head off, there, and a threat to cut one's business head off, here.

Plaintiffs contend, however, that threats to do bodily injury involve an obviously distinguishable form of coerclon and that the present case is not one in which a party has physically prevented the other from carrying out the terms of a contract. We readily assent to the latter part of this argument; defendant was not physically prevented from enforcing the contract. But a distinction depending on the kind of pressure exerted carries little weight. "[D]uress is tested, not by the nature of the threats, but rather by the state of $\mathrm{mInd}$ Induced thereby in the victim." Rubenstein v. Rubenstein, 20 N.J. 359, 368, 120 A.2d II, 15 (1956). See also Wise v. Midtown Motors, Inc., 231 Minn. 46, 42 N.W.2d 404, 20 A.L.R.2d 735 (Sup.Ct. 1950); 17 C.J.S. Contracts \$ 175, p. 534, text at note 60 . And in the present case, when plaintiffs attorney threatened the bullder that he would be ruined if the Wolfs were to be held to the bargain, the Impress was the same as if physical pressure had been exerted. In the light of the Rubensteln case, It is significant, and perhaps crucially so, that defendant was as effectively prevented from forcing the wolfs to comply with the contract as if a more Immedlate form of coercion had been employed.

Yet it was not indicated in the Rubenstein case that a party is to be relleved of the consequences of his action in all instances where the pressure used has had its designed effect, in all cases where he has been deprived of the exerclse of his free will and constrained by the other to act contrary to his inclination and best interests. So much is evident from the court's qualification that "the pressure must be wrongful, and not all pressure is wrongful." $20 \mathrm{~N}$.J. at page 367,120 A.2d at page i5. It is also evident from the reference to 5 WIlliston, Contracts (rev. ed. i937), \$\$ 1606, 1607, pp. 4500, 4503. That authority, in language more nearly approprlate to the facts here, states:

"Save under exceptional circumstances, the threatened act must be wrongful; it is not enough that the person obtaining the benefit threatened intentionally to injure the business, provided his threatened act was legal; and certainly there is no broad doctrine 
forbidding a person from taking advantage of the adversity of another to drive a hard bargaln." Ibid., $\$ 1618$, p. 4523.

In this regard, plaintiffs assert that, once they bought the house, they had a legal right to sell to whomever they wished. They rely on the famillar general rule to the effect that a threat to do what one has a legal right to do does not constitute duress. See, e.g., Smith v. White, 125 N.J.L. 498, 500, 16 A.2d 628 (E. \& A. 1940); Standard Radio Corp. v. Trlangle Radio Tubes, Inc., 125 N.J.L. 131, 14 A.2d 763 (Sup. Ct. 1940); 17A Am.Jur., Duress and Undue Influence, \$ 18, p. 580. Compare 1d., \$ 11, p. 572, text at note 14. That proposition, however, is not an entirely correct statement of the law of duress as it has developed in this jurisdlction. Under the modern view, acts or threats cannot constltute duress unless they are wrongful; but a threat may be wrongful even though the act threatened is lawful. We have come to deal, in terms of the business compulsion doctrine, with acts and threats that are wrongful, not necessarlly in a legal, but in a moral or equitable sense. See, generally, Woodslde Homes, Inc. $v$. Town of Morristown, 26 N.J. 529, 544, 141 A.2d 8 (1958); S. P. Dunham \& Co. V. Kudra, 44 N.J.Super. 656, 131 A.2d 306 (App.Div. 1957); Annotation, 79 A.L.R. 655 (1932).

The leading case in this state on the subject of moral duress is Miller v. Elsele, III N.J.L. 268, 275-276, 168 A. 426, 427 (E. \& A. 1933), where the court quoted approvingly the definition of duress set forth in the Restatement, Contracts, $\$ 492(\mathrm{~g})$, p. 941 :

"Acts or threats cannot constitute duress unless they are wrongful, even though they exert such pressure as to preclude the exerclse of free judgment. But acts may be wrongful within the meaning of this rule though they are not criminal or tortious or in violation of a contractual duty. Just as acts contracted for may be against public policy and the contract vitiated for that reason, though the law imposes no penalty for doing them, so acts that involve abuse of legal remedies or that are wrongful in a moral sense; If made use of as a means of causling fear, vitiate a transaction induced by that fear, though they may not in themselves be legal wrongs."

Further instructive is the decision in Hochman v. Zigler's Inc., 139 N.J.Eq. 139, 143, 50 A.2d 97, 100 (Ch. 1946). In that case, when the lease of a small businessman expired, the lessor refused to renew. The lessor sald, however, that he would lease to a purchaser of the business if the tenant could find one. The tenant proceeded to find a buyer who agreed to pay $\$ 7,800$, but the lessor refused to execute a lease with the buyer unless the tenant pald over to him $\$ 3,500$ of the purchase prlce. The tenant, whose business was worth but a mere $\$ 500$ if forced to ilquldate, succumbed to the lessor's pressure. Notwlthstanding that the defendant-lessor had the undoubted legal right to refuse to execute a lease, the court concluded that any defense on this ground was but a "mere legallsm." The lessor was "compelled to disgorge," the court stating:

"Judgment whether the threatened action is wrongful or not is colored by the object of the threat. If the threat is made to induce the opposite party to do only what is reasonable, the court is apt 
to consider the threatened action not wrongful unless it is actionable in itself. But if the threat is made for an outrageous purpose, a more critical standard is applied to the threatened action."

The sale of a development home to an "undesirable purchaser" is, of course, a perfectly legal act regardless of any adverse effect it may have on the fortunes of the developer's enterprise. But where a party for purely maliclous and unconsclonable motives threatens to resell such a home to a purchaser, specially selected because he would be undesirable, for the sole purpose of injuring the bullder's business, fundamental fairness requires the conclusion that his conduct in making this threat be deemed "wrongful," as the term is used in the law of duress. In our judgment, wrongful pressure was brought to bear on the defendant; he was thereby com pelled to forego the right to hold plaintiffs to the contract they voluntarily signed.

As we noted above, if one party prevents another from performing a contract, the latter may treat the contract as breached, and recover damages. There is no reason why, in the application of this rule, economic or moral duress should not be treated as the equivalent of physical duress. We therefore hold that if the threats were in fact made and if the defendant actually belleved that they would be carried out, and Field's will was thereby overborne, defendant was justified in treating the contract as breached and is entitled to recover whatever damages resulted therefrom.

We have declded that the interests of justice call for a remand of this case to the County Court. This disposition is made necessary by the circumstance that the record on appeal is somewhat obscure in several respects, now to be discussed. There is first the question as to whether the trial judge gave credence to the testimony of defendant's representatives concerning the making of the threats by plalntiffs' attorney. The op inion of the court makes reference to a "so called threat," but this terminology does not clearly make known what the actual findings of the trlal judge were in this respect. This important factual issue should not be permitted to remain in doubt. Attention should also be directed to the question of whether or not the defendant's will was really overborne; that is, whether Fleld actually belleved plaintiffs' attorney would carry out his threat and whether FIeld was actually fearful of the result.

Moreover, should the trlal judge decide in defendant's favor on the issue of actual duress, there remalns for adjudication the actual amount by whlch defendant was damaged by reason of plaintiffs' breach. Although the agreement of sale provides for liquidated damages, such provision is operative only upon the contingency that the buyer failed to make additional payments or falled to make settlement, nelther of which, as we have seen, is the gravamen of the defense. It will therefore be necessary for the court, upon remand, to determine, from the present record if it can, whatever damages defendant sustalned as a result of plalntiffs breach. 
The judgment is remanded for further proceedings not inconsistent with this opinion.

\section{NOTES}

(1) What is the basis for concluding that a contract is unenforceable because of duress? Is it because the "injured" party was denied freedom of cholce? Or is it because of a social pollcy against the inequality of bargaining positions? Is the unconscionable contract lllustrated in the Williams case, which follows, merely an extension of the duress doctrine?

(2) Note, Economic Duress After the Demise of Free Will Theory: A Proposed Tort Analysis, 53 lowa L. Rev. 892-900 (1968):

When one party wrongfully threatens another with severe economic loss if he does not enter a proposed contract, and the threatened party acquiesces solely because of the wrongful threat, the injury to the threatened party may be redressed through the legal doctrine of economic duress. This doctrine may be used as an affirmative defense in an action to enforce the coerced contract as the basis for a restitution suit to recover payments made under the coerced contract or as support for a tort action for damages resulting from the coerced contract. The limits of the doctrine, however, are not clear, and the courts have not used consistent standards for a finding of duress. It is the function of this Note to investigate the purpose of the economic duress doctrine and to formulate analytical criteria applicable to all economic duress cases.

Duress arose at common law as an adjunct to tort law. Relief was initially restricted to cases in which a transfer of property resulted from threats of physical violence or the actual imprisonment of the victim. The courts further required that the threats or pressures be sufficlent to overcome the will of a man of "ordinary firmness." These restrictions were gradually relaxed, and the doctrine of duress was extended into the area of economic pressure, although its relationship to tort law was maintained. The first economic pressure recognized as duress was the wrongful detention of another's property. This crude economic pressure, independently wrongful as a tort, was labelled "duress of goods," and it represented a great advance in the development of economic duress.

American courts in the nineteenth century expanded the concept of duress to invalidate transfers induced by more subtle economic pressure. Guided by the rationale of equity courts in undue influence cases and by the prevalling subjective will theory of contracts, the courts eventually rejected the "ordinary firmness" test in favor of a subjective test for duress. Under this test, agreements were held to be voldable for lack of free contractual consent if the court determined that the threats or actions of the stronger party actually overcame the victim's will. Since the early twentieth century, most

70. 
American courts have used this subjective test in cases of both economic and physical duress.

The free will concept, however, has serlous shortcomings. Because both nomal contracts and those formed under duress result from a choice between alternative evils, it is impossible to distinguish one situation from the other on the basls of any difference in the freedom of the consent. The free wlll test, therefore, has IIt+le analytical value in itself, and many writers have begun to equate a finding of duress to a moral judgment on the falrness of the alternatives presented by the threatenling party. These writers have presented many different standards for determining whether the pressures exerted rise to the level of duress. One authority focused on the "essentlal and sufficlent" elements of duress, which he found to be the wrongfulness of the threats and the inadequacy of alternative legal remedies open to the threatened party at the time of the threats. Another writer rejected these factors and argued that the requisites for a finding of duress should be unequal bargaining positions of the parties and a disproportionate exchange resulting in unjust enrlchment to the stronger party.

The theoretical confusion surrounding the duress area is reflected in the judiclal decisions. Courts appear to glve controllIng weight to a variety of factors, including relative bargaining positions of the parties, adequacy of alternative legal remedies, gravity of the threatened evil, wrongfulness or Illegality of the threats, falrness of the resulting bargain, and ratification by the allegedly coerced party. Some courts have held that there can be no duress if the victim had an opportunity to consult with a lawyer, If he had time for deliberation and reflection between the time of the threats and the tIme of the agreement, if he had knowledge of all the facts, or if the overwhelming pressure was the result of external circumstances. A few courts have decided duress cases without resort to any theoretical or analytical framework, and others, recognizing the fluidity and vagueness of the duress doctrine, have concluded that each case must be declded solely on: its own facts. These discrepancles in decisional factors employed, together with the ambigulty of the common free wlll test, have contributed to lack of predictability, Inaccurate use of precedents, confusion between the functions of judge and jury, and timidity in the extension of the duress doctrine.

\section{Purpose and Classlfication of Duress Doctrine}

\section{A. Purpose}

The analytical confusion in the duress area reflects a confusion concerning the purpose of the duress doctrine. Clarlfication of this purpose will facllitate classification of duress as a tort, contract, or quasl-contract action, and allow the use of an estabIIshed analytlcal scheme for dealling. with duress cases. Several theorles have been advanced to explain the purpose of the duress 
doctrine. Roscoe Pound thought the purpose was to protect an individual's interest in the exercise of his free will. This theory, however, does not adequately reflect the principles underlying duress. Duress law does not compensate the individual for every infringement of his right to exercise his free will. No recovery is allowed unless an economic loss results. Furthermore, even when a loss results, Pound's theory does not help to determine if it should be compensated, because his theory rests on the unsupportable premise that free will is present in the normal contract case and absent in cases involving duress. Both normal and coerced contracts result from a choice between alternative evils, and all contracts involve some degree of coercion. Under a strict application of Pound's theory the wrongfulness of the pressures should derive solely from their tendency to deprive a victlm of his free will. However, most courts require an external showing that the pressure exerted was wrongful, independent of a showing of its tendency to deprive the victim of his free will.

Another theory, advanced by John P. Dawson, states that the purpose of a duress action is to prevent unjust enrichment resulting from unequal bargaining positions. The concept of unjust enrichment, however, focuses on wrongful retention of benefits, ignoring the wrongfulness of the means used to obtain the benefits. There may be unjust enrichment through a disproportionate bargain without wrongful threats, but recovery in that case, through restitution of the excessive benefit, is logically unrelated to duress. The concept of duress applies only to situations in which the means used to obtain a benefit are wrongful. The coercer is unjustly enriched because the means employed to gain enrichment are wrongful, and the principle of unjust enrichment applies only as a corollary to the primary culpability principle.

Another writer, Kenneth S. Carlston, has argued that the purpose of the duress doctrine is to insure substantial equality in bargaining position, thereby protecting the bargaining process. This purpose, however, when applied to economic duress, is difficult to distinguish from Carlston's formulation of the purpose of antitrust law. Both aim at controlling abuses in the exercise of economic power. Carlston's analysis leaves unclear what should be the proper scope of the legislative antitrust remedy in relation to the judicial remedy of duress. If both duress doctrine and antitrust law aim at controliIng abuses of economic power, it is necessary to distinguish the situation to which each properly applies.

A complete description of the purpose of economic duress doctrine, therefore, should properly describe the interest to be protected, accounting for the requirement that the coercing pressure be wrongful, and distinguish the duress doctrine from antitrust law. It has been established that the duress doctrine does not protect the personal interest in the exercise of the free will. Two posslble protectable economic interests, however, $\cos$ be isolated: the economic interest which is threatened by the threatened alternative 
to the agreement, and the economic interest which is damaged by the coerced agreement. It is clear that the doctrine of economic duress protects only the latter economic interest, because the threat is never carried out where the duress is effective. The compensation is measured by the degree of injury caused by the coerced agreement.

The wrongfulness of the coercer's conduct derives from the fact that the threatened party was forced to accept the contract, not from any inherent wrongfulness of the act threatened. Ordinarily a party may threaten to do what is lawful; however, a coercer's threats may be wrongful even though the threatened action would have been legal. The key factor, therefore, must be the fact that the threatened action is an unreasonable alternative to an injurious contractual demand in a bargain situation. The wrongfulness of the coercer's conduct must be related to the unreasonableness of the alternatives which he presents to the weaker party in a bargaining situation. The inherent wrongfulness of either alternative is relevant only insofar as it shows the unreasonableness of the alternatives. The purpose of the duress doctrine, therefore, is to prevent a stronger party from offering an unreasonable choice of alternatives to a weaker party in a bargain situation.

This formulation of the purpose of duress doctrine permits a distinction between the scope of judiclal duress doctrine and that of legislative antitrust law. This distinction depends on the different interests protected by the two doctrines. Antitrust law aims at protecting the general societal interest in the maintenance of competition in a free market from the anticompetitive accumulation of monopolistic economic power. Duress actions protect an individual's economic interests from the unreasonable exercise of economic power in a bargain situation. The different interests protected lead to different requirements for a successful action in the two fields. Proof of an antitrust violation requires a showing that competition was reduced by the anticompetitive action. Proof of duress, on the other hand, requires a showing that an individual's economic interests were injured. Simllarly, different standards of wrongfulness apply in the two areas. In antitrust law, the wrongfulness of the defendant's conduct derives solely from its tendency to decrease competition. The reasonableness of the means used to reduce competition is not decisive. In duress actions the wrongfulness of the coercer's conduct derives from the unreasonableness of the means used to force the other party into an injurlous contract. Thus, consistent with the different wrongfulness standards, a party may be guilty of an antitrust violation because an anticompetitive practice has a coercive effect, but be innocent of duress because the alternatives he presents in the individual bargain situations are reasonable. 
WILLIAMS $V$. WALKER-THOMAS FURNITURE $C O$.

350 F.2d 445 (D.C.CIr. 1965)

\section{J. SKELLY WRIGHT, Circult Judge:}

Appellee, Walker-Thomas Furniture Company, operates a retall furnlture store in the District of Columbla. During the perlod from 1957 to 1962 each appellant in these cases purchased a number of household items from walkerThomas, for which payment was to be made in installments. The terms of each purchase were contained in a printed form contract whlch set forth the value of the purchased item and purported to lease the item to appellant for a stipulated monthly rent payment. The contract then provided, in substance, that title would remain in Walker-Thomas until the total of all the monthly payments made equaled the stated value of the item, at which time appellants could take title. In the event of a default in the payment of any monthly instaliment, Walker-Thomas could repossess the 1 tem.

The contract further provided that "the amount of each periodical installment payment to be made by [purchaser] to the Company under this present lease shall be inclusive of and not in addition to the amount of each installment payment to be made by [purchaser] under such prior leases, bills or accounts; and all payments now and hereafter made by [purchaser] shail be credited prorata on all outstanding leases, bills and accounts due the Company by [purchaser] at the time each such payment is made." "Emphasis added.). The effect of this rather obscure provision was to keep a balance due on every item purchased until the balance due on all items, whenever purchased, was liquidated. As a result, the debt Incurred at the time of purchase of each item was secured by the right to repossess all the items previously purchased by the same purchaser, and each new item purchased automatically became subject to a security interest arising out of the previous dealings.

On May 12, 1962, appellant Thorne purchased an item described as a Daveno, three tables, and two lamps, having total stated value of $\$ 391.10$. Shortly thereafter, he defaulted on his monthly payments and appellee sought to replevy all the items purchased since the first transaction in 1958. Similarly, on April 17, 1962, appellant Williams bought a stereo set of stated value of $\$ 514.95$. She too defaulted shortly thereafter, and appellee sought to replevy all the items purchased since December, 1957. The Court of General Sessions granted judgment for appellee. The District of Columbia Court of Appeals affirmed, and we granted appellants' motion for leave to appeal to this court.

Footnotes have been renumbered--some have been omitted.

1. At the time of this purchase her account showed a balance of $\$ 164$ still owing from her prior purchases. The total of all the purchases made over the years in question came to $\$ 1,800$. The total payments amounted to $\$ 1,400$. 
Appellants' principal contention, rejected by both the trial and the appellate courts below, is that these contracts, or at least some of them, are unconscionable and, hence, not enforceable. in its opinion in Williams v. Walker-Thomas Furniture Company, 198 A.2d 914, 916 (1964), the District of Columbia Court of Appeals explained its rejection of this contention as follows:

"Appellant's second argument presents a more serious question. The record reveals that prior to the last purchase appellant had reduced the balance in her account to $\$ 164$. The last purchase, a stereo set, raised the balance due to $\$ 678$. Significantly, at the time of this and the preceding purchases, appellee was aware of appellant's financlal position. The reverse side of the stereo contract listed the name of appellant's social worker and her $\$ 218$ monthly stipend from the government. Nevertheless, with full knowledge that appellant had to feed, clothe and support both herself and seven children on this amount, appellee sold her a $\$ 514$ stereo set.

"We cannot condemn too strongly appellee's conduct. It raises serious questions of sharp practice and irresponsible business dealings. A review of the legislation in the District of Columbia affecting retail sales and the pertinent decisions of the highest court in this jurisdiction disclose, however, no ground upon which this court can declare the contracts in question contrary to public policy. We note that were the Maryland Retail Installment Sales Act, A.rt. 8358 128-153, or its equivalent, in force in the District of Columbia, we could grant appellant appropriate relief. We think Congress should consider corrective legislation to protect the public from such exploitive contracts as were utilized in the case at bar."

We do not agree that the court lacked the power to refuse enforcement to contracts found to be unconscionable. In other jurisdictions, it has been held as a matter of common law that unconscionable contracts are not enforceable. While no decision of this court so holding has been found, the notion that an unconscionable bargain should not be given full enforcement is by no means novel. In Scott v. United States, 79 U.S. ( 12 Wall.) 443, 445, 20 L.Ed. 438 (1870), the Supreme Court stated:

"** If a contract be unreasonable and unconscionable, but not void for fraud, a court of law will give to the party who sues for its breach damages, not according to its letter, but only such as he is equitably entitled to. * * *"

Since we have never adopted or rejected such a rule, the question here presented is actually one of first impression.

Congress has recently enacted the UnI form Commercial Code, which specifically provides that the court may refuse to enforce a contract which it finds to be unconsclonable at the time it was made. 28 D.C.CODE \$ 2-302 (Supp. IV 1965). The enactment of this section, which occurred subsequent 
to the contracts here in sult, does not mean that the common law of the Distrlct of Columbla was otherwlse at the time of enactment, nor does it preclude the court from adopting a simllar rule in the exerclse of its powers to develop the common law for the District of Columbla. In fact, in vlew of the absence of prlor authority on the polnt, we consider the congressional adoption of \$2-302 persuasive authority for following the rationale of the cases from which the section is explicitly derlved. Accordingly, we hold that where the element of unconscionablility is present at the time a contract is made, the contract should not be enforced.

Unconscionability has generally been recognized to include an absence of meaningfui cholce on the part of one of the partles together with contract terms which are unreasonably favorable to the other party. Whether a meaningful cholce is present in a particular case can only be determined by consideration of all the circumstances surrounding the transaction. In many cases the meaningfulness of the cholce is negated by a gross inequality of bargalning power. 2 The manner in which the contract was entered is also relevant to this consideration. Did each party to the contract, considering his obvious education or lack of it, have a reasonable opportunity to understand the terms of the contract, or were the important terms hidden in a maze of fine print and minimized by deceptive sales practices? Ordinarlly, one who signs an agreement without full knowledge of its terms might be held to assume the risk that he has entered a one-sided bargain. 3

2. See Henningsen v. Bloomfield Motors, Inc., supra Note 2, 161 A.2d at 86, and authorities there cited. Inquiry into the relative bargaining power of the two parties is not an inquiry wholly divorced from the general question of unconscionablility, since a one-slded bargain is itself evidence of the inequallty of the bargalning parties. This fact was vaguely recognized in the common law doctrine of intrinsic fraud, that is, fraud whlch can be presumed from the grossly unfalr nature of the terms of the contract. See the oft-quoted statement of Lord Hardwlcke in Earl of Chesterfleld v. Janssen, 28 Eng. Rep. 82, 100 (1751):

"* * * [Fraud] may be apparent from the intrinsic nature and subject of the bargain itself; such as no man in his senses and not under delusion would make * **."

And cf. Hume v. United States, supra Note 3, 132 U.S. at 413, 10 S.Ct. at 137, where the Court characterized the English cases as "cases in which one party took advantage of the other's Ignorance of arithmetic to Impose upon hlm, and the fraud was apparent from the face of the contracts." See also Greer v. Tweed, supra Note 3.

3. See RESTATEMENT, CONTRACTS $\$ 70$ (1932); Note', 63 HARV. L. REV. 494 (1950). See also Daley v. People's Bullding, Loan \& Savings Ass'n, 178 Mass. 13, 59 N.E. 452, 453 ( 1901 ), in whlch Mr. Justlce Holmes, whlle sitting on the Supreme Judiclal Court of Massachusetts, made this observation:

$" * * *$ Courts are less and less disposed to Interfere with parties making such contracts as they choose, so long as they interfere with no one's welfare but their own. *** It will be understood that we are speaking of parties standing in an equal position where neither has any oppresslve advantage or power ***." 
But when a party of $11+t l e$ bargainlng power, and hence $11+t+l e$ real cholce, signs a commerclally unreasonable contract wlth little or no knowledge of its terms, It is hardly IIkely that hls consent, or even an objective manifestation of hls consent, was ever glven to all the terms. In such a case the usual rule that the terms of the agreement are not to be questloned should be abandoned and the court should conslder whether the terms of the contract are so unfair that enforcement should be withheld.

In determining reasonableness or falrness, the primary concern must be with the terms of the contract consldered in IIght of the clrcumstances existing when the contract was made. The test is not simple, nor can it be mechanlcally applled. The terms are to be considered "In the light of the general commerclal background and the commerclal needs of the particular trade or case." 4 corbln suggests the test as belng whether the terms are "so extreme as to appear unconsclonable accordling to the mores and bus Iness practlces of the tIme and place." I CORBIN, op. clt. supra Note 2. We think this formulation correctly states the test to be applied In those cases where no meaningful cholce was exerclsed upon enterlng the contract.

Because the trlal court and the appellate court did not feel that enforcement could be refused, no findings were made on the possible unconsclonablility of the contracts in these cases. Since the record is not sufflclent for our declding the Issue as a matter of law, the cases must be remanded to the trlal court for further proceedlings.

So ordered.

DANAHER, Circult Judge (dlssenting):

The Distrlct of Columbla Court of Appeals obvlously was as unhappy about the situation here presented as any of us can passibly be. Its op Inion In the Willlams case, quoted in the majorlty text, concludes: "We think Congress should consider corrective legislation to protect the public from such exploltive contracts as were utllized in the case at bar."

My vlew is thus summed up by an able court whlch made no finding that there had actually been sharp practlce. Rather the appellant soems to havo known precisely where she stood.

There are many aspects of public pollicy here involved. What is a luxury to some may seem an outright necessity to others. Is publlc oversight to be required of the expendltures of rellef funds? A washing machine, e.g. , In the hands of a rellef cllent might become a frultful source of income. Many rellef cllents may well need credit, and certain business establlshments wlll take long chances on the sale of Items, expecting thelr pricing policles will afford a degree of protection commensurate with the rlsk. Perhaps a remedy when necessary wlll be found within the provislons of the "Loan Shark" law, D.C.CODE \$\$ 26-601 et seq. (1961).

4. Comment, Uniform Commerclal Code $\$ 2-307$. 
1 mention such matters only to emphaslze the destrablility of a cautlous approach to any such problem, partlcularly since the law for so long has allowed partles such great latltude in maklng thelr own contracts, I dare say there must annually be thousands upon thousands of Instailment credit transactions in this jurisdiction, and one can only speculate as to the effect the declsion in these cases wlll have.

I joln the District of Columbla Court of Appeals in Its disposition of the issues.

LEFF, UNCONSCIONABILITY AND THE CODE--THE EMPEROR'S NEW CLAUSE I15 U. Pa. L. Rev. 485, 547-59 (1967)

\section{* * * \\ The Cases "UsIng" 2-302}

- . Strlctly speaking, only one reported case relles upon section 2-302 of the Code even as an alternatl ve ground of holding. I In Amerlcan Home Improvement, Inc. v. Maclver, $[105$ N.H. 435, 201 A.2d $886(1964)]$ the plaintlff was in the business of selling and Installing home improvements. It agreed with the defendant to "furnlsh and Install 14 comblnation wI ndows and one door" and "flintcoat the slde walls" on defendant's home, all for $\$ 1,759.00$. Since the defendant was apparently unwlliling or unable to pay cash, the plalntlff undertook to arrange long-term financling, and furnished defendant with an application to a finance company (apparently in some way allled or afflllated with the plaintiff). This application was shortly "accepted," and defendant was notlfled In writing that his payments for the Improvements would be $\$ 42.81$ per month for sixty months (a grand total of $\$ 2,568.60$ ) which Included "prihclpal, Interest and 11 fe and disablilty Insurance." Plalntiff commenced work, but after it had completed only a negligible portion of the job it was asked by defendant to stop and it complled, thereafter sulng defendant for damages for breach of contract.

On these facts, the New Hampshire court need never have reached any unconsclonablility question, There was in effect in the Jurlsdiction a "truth-in-lending" statute 2 whlch applled to the transaction. The court

Footnotes have been renumbered--some have been omitted.

1. This. Is not strlctly true, perhaps. One Referee in Bankruptcy recently held two securlty agreements "unconsclonable," purportedly relylng on UCC S 2-302. Matter of ElkIns-Dell Mfg. Co. (E.D. Pa.); Matter of Dorset Steel Equipment Co. (E.D. Pa.), both descrlbed at 39 Ref. J. 115-16 (1965). On appeal, the Dlstrict Court remanded both cases for further factual development, but decllned speclflcally to hold \& 2-302 applicable to nonsales agreements. In re Elkins-Dell $\mathrm{Mfg}$. Co., 253 F. Supp. 864,873 n.4 (E.D. Pa. 1966).

2. N.H. REV. STAT. ANN. \$ 399-B:2 (Supp. 1965) forbids the extenston of credit unless at the time thereof the borrower is furnished 
could have relled upon that statute to strike the contract, and Indeed did so as an alternative ground of decision. But the court most speclfically made it a polnt not to rest its decision solely upon the disclosure statute. It sald:

There is another and Independent reason why the recovery should be barred in the present case because the transaction was unconsclonable. "The courts have often avolded the enforcement of unconsionable provisions in long printed standardized contracts, in part by the process of "interpretation" agalnst the partles using them, and in part by the method used by Lord Nelson at Copenhagen." I Corbin, Contracts, s. 128 (1963). Without using elther of these methods rellance can be placed upon the Uniform Commerclal Code (U.C.C. 2-302(1) [quotation of section omitted]. ...

Inasmuch as the defendants have recelved little or nothing of value and under the transaction they entered into they were paying $\$ 1,609$ for goods and servlces valued at far less, the contract should not be enforced because of its unconscionable features. This is not a new thought or a now rule in this jurisdiction. See Morrill $v$. Bank, 90 N.H. 358, 365, 9 A.2d 519, 525; "It has long been the law in this state that contracts may be declared vold because unconscionable and oppressive. . . ."

All right, then. As of the time of writlng, the only case which has relled upon section 2-302 as a basls of decislon has decided that "unconscionable" means "too expensive." And certainly there is no Immutable princlple displayed in fixed stars that would make that particular meaning of unconscionable Inconcelvable. I have earller suggested that in fact that was the prlmary meaning of unconsclonabllity in some of the early drafts of the Code, and that it was its only meanlng as used by courts of equity. Certainly the idea that a strikingly disproportionate exchange should be voldable has not destroyed the commerce of the many jurisdictions which utllize a laeslo enormls doctrine in one form or another. On the other

a clear statement in writing setting forth the finance charges, expressed in dollars, rate of interest, or monthly rate of charge, or a combination thereof, to be borne by such person in connection with such extension of credit as originally scheduled.

The court concluded reasonably enough that the requl rements of this statute had not been met by the plaintlffs, and that

In the clrcumstances of the present case... the purpose of the disclosure statute will be implemented by denying recovery to the plaintiff on its contract and granting the defendants ${ }^{p}$ motion to dismiss.

105 N.H. at 439,201 A.2d at 888 . 
hand one may certainly speculate on whether the leglstatures which have flocked to embrace the code would have been wlllling to adopt a provision whlch frankly and openly declared that overcharges of some large but unspecified degree could be invalidated by courts on an ad hoc basls, at least as part of a commerclal code.

Let us assume, however, that a system of jurisprudence ought to have some way to deal with transactions in which one party is giving up vastly more than he is getting, and that this purpose is at least one of those that section 2-302 is deslgned to serve. Even given that assumption, one has stlll to ask whether the best way to inject that supervisory power into the law is to subsume it under a high-level abstraction 11 ke "unconscionabllity." After all, a laeslo enormis type of statute is not very hard to draft, as elther a flat-percentage or a "grossly-too-much" provislon. The declsion in the Maclver case exposes the weaknesses of abstraction so deliclously that it justifles esurlent consideration. Let me quote the court's total discussion of why the contract was unconscionable.

In examining the exhibits and agreed facts in this case we find that to settle the princlpal debt of $\$ 1,759$ the defendants signed Instruments obligating them to pay $\$ 42.81$ for 60 months, makling a total payment of $\$ 2,568.60$, or an Increase of $\$ 809.60$. over the contract price. In rellance upon the total payment the defendants were to make, the plaintlffs pay a sales commlssion of $\$ 800$. Counsel suggests that the goods and services to be furnished the defendants thus had a value of $\$ 959$, for which they would pay an additional $\$ 1,609.60$ computed as follows:

"Value of goods and services Commission Interest and carrying charges

800.00

809.60
$\$ 959.00$

$1,609.60$

\section{Total Payment}

$\$ 2,568.60^{\prime \prime}$

This is breathtaking economics. Note first of all the court's assumption that the seller's cost of dlstrlbution ( $h l s$ presumably-fast-talklng salesman's commission) is no part of the "value" of the goods to the purchaser, so that it must be totally elimlnated from any evaluatlon of the falrness of the exchange. On this reasoning, the salary of sales staff is not a factor falrly to be consldered when declding the falrness of a retail price. (This is not to say that a grotesquely uneconomlc form of distribution enrlches one who purchases from the distributor; It does, however, suggest that IIfe is not so easy that the commission may simply be "drilled out". of the "value" in evaluating the falrness of the exchange.)

Then we come to the treatment of the "Interest and carrying charges" by the court. Here it seems that it is enough for the judge that the amount certainly looks like a great deal. He makes absolutely no attempt to work out what the true effective yearly rate of interest is for this five-year pay out. Actually it works out to a bit over $18 \%$ per annum. This may seem high, but it is not out of IIne with the rates permitted under statutes 
which regulate Installiment purchases and loans, not to mention rates. charged where not regulated. The Important matter, however, is not whether this rate is "falr" or not; It is that the court in this case went on nothing but guesswork to reach 1 ts declsion, examined none of the relevant considerations and was encouraged by 2-302 to behave in just that way. Had the section been in less abstract terms, perhaps an examination of the relevant factors would have taken place. It does seem that a judge who is forced to recognlze by the form of the statute upon which he is relying that he is supposed to evaluate the actual economlc exchange is IIkely to feel called upon to see what that exchange in fact is, and how it accords with contemporary practlces. When the key evaluative word, however, is a description of the judge's own state of $\mathrm{m} I$ nd rather than of the situation whlch might be justifled in producling such a state, the likelihood that the court wlll even examine the relevant questions is severely lessened.

As noted earller, the Maclver case is the only one reported which has. relled upon 2-302 as a basis of declslon. One very recent case; however, whlch has attracted substantlal attention from the commentators, clearly would have been declded on the basls of 2-302 had the statute been In effect at the time of the relevant transaction, and In fact was declded as If the section were the law of the jurlsdiction. In that case, Williams $v$. Walker-Thomas Furnlture Co. . .

For those of us who have an Instinctlve and Infallible sense of justice (and which of us does not), any other result in this case is unimaginable. But there are grounds for quibolling about the court's (and the Code's) methodology. Judge Wright found unconsclonabllity easy to descrlbe:

Unconsclonablility has generally been recognlzed to Include an absence of meanlingful cholce on the part of one of the partles tcgether with contract terms whlch are unreasonably favorable to the other party. . . [In the footnote which supports this statement, cltation is to Henningsen $v$. Bloomfleld Motors, Inc., 32 N.J. 358, 161 A.2d 69 (1960), and Campbell Soup Co. V. Wentz. $172 \mathrm{~F} .2 \mathrm{~d} 80$ (3d Clr. 1948) only.] In many cases the meaningfulness of the cholce is negated by a gross inequallty of bargaining power.

That Is, there is immedlate recognition that unconsclonablilty has to have two focl, the negotlation whlch led to the contract and that contract's terms. As for the procedural aspect, whlle there is no finding that this was the only credlt furnlture store open to Mrs. WIlllams, or that even If it were not, they all had substantlally the same contract (whl ch was the sltuation in the Henningsen case so heavily relled upon by the court), one may assume that the form Mrs. WIIllams slgned was essentially the only kInd of form open to her. A person's "relevant market" may falrly be the one he can reasonably be expected to know about or dare to use. In other words, the local stores may be a local person's relevant market because of hIs Ignorance, and If they are all as one on something, as to him they are a monopoly. And besides, in this case the court made an almost-finding of contracting procedures whlch went beyond the mere use of a form or even of a contract of adhesion, whlch reached, in fact, at least some level of quasl-fraud. Judge Wright asks: 
Did each party to the contract, consldering his obvlous education or lack of it, have a reasonable opportunlty to understand the terms of the contract, or were the important terms hidden in a maze of fine print and minimlzed by deceptlve sales practices?

There was apparently no problem with the answer, for after glving IIp service to the "usual rule" that one who signs an agreement is bound to all of Its terms, he sald:

But when a party of $11+t+l e$ bargaining power, and hence $11+t l e$ real cholce, signs a commerclally unreasonable contract with $11+t$ le or no knowledge of its terms. . . the usual rule... should be abandoned. . .

It is hard to fault the court's argument on the procedural unconsclonabillty aspects of this case. While It might sometimes be difficult to decide whether a specles or level of bargalning ought to protect a contract from section 2-302, it is not difflcult here. If the unconsclonabllity section is to be applicable to any contract, it must be to one "bargalned" as this one was.

But there is nic need to labor this point. Flnding that the bargaining procedure Involved will not insulate the contract from judlcial scrutiny. under section 2-302 is only the first and less difficult step in the process of using that section. Once one decldes that the contract is vulnerable to judiclal meddling, there stlll remalns to be declded whether the provision or contract is "unconsclonable." For that determination Judge Wright also articulated a test:

In determining reasonableness or falrness, the primary concern must be with the terms of the contract considered in light of the circumstances existing when the contract was made. The test is not simple, nor can it be mechanically applled. The terms are to be considered "In the light of the general commerclal background and the commerclal needs of the partlcular trade or case" [clting "Comment Unlform Commercial Code sec. 2-307," but obviously meaning 2-302]. Corbin suggests the test as belng whether the terms are "so extreme as to appear unconsclonable according to the mores and business practices of the time and place." . . We think thls formulation correctly states the test to be applled In those cases where no meaningful choice was exerclsed upon entering the contract.

How does that test apply to the wllllams facts? What is it about Mrs. Willlams" contract which is "unconsclonable"? Surprlsingly, the answer is not clear, even about what in the contract is bad. It seems, however, that there are two possibilities. First, It may be that the provislon by which each item purchased became security for all items purchased was the objectionable feature of the contract. Or it $\mathrm{mlght}$ be that the furnlture company sold thls expensive stereo set to this particular party whlch forms the unconsclonability of the contract. If the vice is the add-on clause, then one encounters the now-famlliar problem: such a clause is hardly such a moral outrage as by Itself meets Judge Wright's standard of belng "so extreme as 
to appear unconscionable according to the mores and buslness practices of the time and place." The lower court in the Wllllams case called attention, for Instance, to a Maryland statute regulating retall Installment sales under whlch Mrs. WIIllams might have been relleved, noting with regret that the statute was not in effect in the District. What was not pointed out by the lower court (and certainly not by the upper court) was that the State of Maryland had found nothing illegal per se about add-on provisions, in fact speclfically permitting them and setting out to regulate them in some detall. Of the thirty-seven jurisdlctions which have statutes regulating retall installment sales, only one has a provlsion making add-on clauses impermissible. In such circumstances it does seem a bit much to find "so extreme as to appear unconsclonable accordlng to the mores and buslness practices of the tIme and place" an add-on clause in the District of Calumbla which is used and statutorily permitted almost everyplace else, including contiguous Meryland. One's gorge can hardly be expected to rise with such nice geographic selectivity.

If one is not convinced that the unconscionabillty Inheres in the addon provision, it may be argued that it inheres in the contract as a whole, in the act of having sold this expensive Item to a poor person knowing of her poverty. This is quite clearly the primary significance of the case to some of the commentators. That is the kind of action which the Maryland statute does not deal with, nor do any of the statutes like it: the unconscionablilty of alding or encouraging a person to live beyond his means (without much hope of eventual success). Well, why not make that "unconsclonable" for purposes of sectlon 2-302? After all, In this case Walker-Thomas dld know for a fact that Mrs. Wllllams was on rellef; they knew her income and needs with great particularity: $\$ 218$ per month and seven children. This case does not present any of the sticky close questions of how much of what a seller would have to know (or Inquire about) before belng deemed to know that the buyer shouldn't buy. Moreover, what Mrs. Williams bought this time was a stereo record player. No one could argue that such an article is a "necessity" to a rellef cllent, and thus the dissenting judge's suggestion that "what is a luxury to some may seem an outright necessity to others" hardly applies in this case. Who can doubt but that thls purchase was a frill? So In this case all we would have is a holding that one cannot enforce a contract pursuant to which one has sold luxuries to a poor person (or at least one on rellef) with knowledge or reason to know that he will not be able to pay for them. This is just another class distinction, and distinctions among persons on the bases of the "class" to whlch they belong, that is, on the basis of some common suprapersonal characteristics, is exceedingly common in the law (not to mention ||$f e)$. Such a process immensely simplifles decision by $\mid$ imlting the required inquiry to the person's membership in the class. Once that determination is made, a certain legal result will flow. The classlc instance is the majority-minority dichotomy. Persons under twenty-one cannot, as a general rule, make self-binding contracts. This may be considered a shorthand form of a syllogism which would go something like (a) persons lacking sufficient problty ought not to be allowed to bind themselves; (b) all persons under twenty-one lack sufficlent probity; (c) persons under twenty-one cannot bind themselves. This lllustrates some of the strengths and weaknesses of the class system. The rule is easy to administer because 
a party's age is much easler to determine than his problty. The difficulty is that the easler the classiflcation the less llkely it is to be accurate, because classes are, in fact, hardly ever wholly homogeneous. In our case, for instance, the "mlnor premlse" is false; not all persons under twentyone lack sufflclent problty to bind themselves.

When faced wlth the difflcultles inherent in declding the bargaining falrness of any given transaction, the equity courts, in working out their unconsclonabllity doctrine, simllarly leaned heavliy on relatively gross classiflcations. In effect, they seem contintually to have taken a kind of sub rosa judicial notice of the amount of power of certaln classes of people to take care of themselves, often wlthout too much inqulry into the actual individual bargaining situation. And it is arguable that sometimes they were wrong; not all old ladies or farmers are without defenses. Put brlefly, the typical has a tendency to become stereo-typical, with what may be unpleasant results even for the beneflclarles of the judiclal benevolence. One can see It enshrined In the old Engllsh equlty courts' jolly treatment of English seamen as members of a happy, fun-loving race (with, one supposes, a flne sense of rhythm), but certalnly not to be trusted to take care of themselves. What effect, If any, this had upon the sailors is hidden behlnd the judlclal chuckles as they protected thelr loyal sailor boys, but one cannot help. wonderlng how many sallors managed to get credit at any reasonable prlce. In other words, the benevolent have a tendency to colonize, whether geographically or legally.

Far more economically signiflcant and widespread as an example of the Chancellors' temptation toward stereotyplcal jurisprudence is found in the expectant-heir cases. The most important thing about expectant-helr cases is that there are expectant-helr cases, classlfiable separately as such in treatlses. The Chancellors did not find unfalrness in the price and refuse to enforce because they had no conceptlon of how an expentancy had to be discounted for rlsk; that klnd of sophlstlcation came early. They just set out to protect helrs from the full effect of thelr tendency to live beyond their governors' $11 \mathrm{fe}$ expectancles. Thls was easy to do; it was rare that a judge had to enter into too long a discussion of the actual facts, or to face the real basls of his easy decisicn in the battle between his (there but for the grace of God) grandson and the most-ll kely-Jewlsh moneylender. After all, he had the rubrlc "unconscionable" with which to explain (to himself and to the public) that decision.

Thus, when one asks why a court (llke: the Distrlct of Columbla Court In the Wlillams case) ought not be allowed to subsume its soclal declsions under a high-level abstraction like "unconsclonabllity," one may polnt to the equity cases so many other commentators have polnted to, but for a different reason. One may suggest that flrst (and less Important) it tends to make the true bases of declsions more hidden to those trylng to use them as the basis of future planning. But more important, it tends to permit a court to be nondisclosive about the basis of its decision even to itself; the class determination is so easy and so tempting (and often so heartwarming). More partlcularly wlth respect to the Wllliams case concept that the poor should be discouraged from frlll-buying, no leglslature in America could be persuaded openly to pass such a statute, nor should any be permltted 
to do so sneaklly. If the selling of frllls to the poor is to be discouraged, If the traditlonal middle-class virtues of thrift and chlld care are to be fostered in the deserving poor by a commerclal statute, If one wants to protect a class, improvident by definition, from the depredations of another class, it is at least arguable that one should just up and do so-but clearly. This is not to suggest, for a momemt, anything as stupld as that some "freedom-of-contract" concept ought to prevent, for Instance, the statutory interdiction of an eleven-hour day. It is only to say that when you forbid a contractual practice, you ought to have the political nerve to do so with some understanding (and some disclosure) of what you are dolng.

\section{Conclusion}

I have attempted to describe in some detall the pathology, developmental, morphologlcal and functional, of sectlon 2-302 of the code and its officlal and unofflclal commentaries. The glst of the tale is simple: It is hard to give up an emotionally satisfying Incantation, and the way to keep the glow without the trouble of the meaning is contl nually to increase the abstraction level of the drafting and explainlng language. If for one reason or another (in this case the desire to forward the passage of the whole Code) the academlc community is generally frlendly to the drafting effort, a single provision in a masslve Code may get by even if it has, really, no reallty referent, and all of its explanatory materlal ranges between the Irrelevant and the $\mathrm{mlslead} / \mathrm{ng}$. That this happened with respect to 2-302 the few cases using It are beglnning to show more and more clearly. The world is not golng to come to an end. The courts will most ll kely adjust, encrusting the Irrltating aspects of the sectlon with a smoothing nacre of more or less reasonable appllcations, or the legislatures may act If things get out of hand. Commerce in any event is not golng to grind to a halt because of the weaknesses in 2-302. But the lesson of Its drafting ought nevertheless to be learned: It is easy to say nothing with words. Even if those words make one feel all warm Inslde, the result of sedulously preventing thought about them is likely to lead to more trouble than the draftsmen's cozy glow is worth, as a matter not only of statutory elegance but of effect in the world being, regulated. Subsuming problems is not as good as solving them, and may in fact retard solutions instead. Or, once more to quote Karl Llewellyn (to whom, after all, the last word justly belongs)," "Covert tools are never rellable tools."

3. In Henningsen v. Bloomfleld Motors, Inc., 32 N.J. 358, I6I A.2d 69 (1960), continually clted in the Willlams case (see $350 \mathrm{~F} .2 \mathrm{~d}$ at 448 $\mathrm{n} .2,449 \mathrm{nn} .6 \& 7,450 \mathrm{n} .12)$, it 1 s most slgnlficant that the court did not have $\$ 2-302$ to work with. it was forced, therefore, to face the relevant pollicy questions, which it did in a many-paged op inion. In other words, in Henningsen the New jersey court was forced to talk about the basls for its declsion; in WIIllams and Maclver the courts were most particularly enabled not to. 
DAVIS \& CO. V. MORGAN

H7 Ga. 504, 43 S.E. 732 (1903)

LAMAR, J. Davis \& Co. employed Morgan for one year at $\$ 40$ per month. After the contract had been in force for some time, Morgan recelved an offer of $\$ 65$ per month from a company In Florlda, and mentloned the fact to Davls, saying that of course he would not go without consent. Davis inslsts that he then sald, if Morgan would stay out the balance of the term, and work satisfactorlly, he would glve hIm $\$ 120$ at the end of the year: Morgan says that Davis stated, "I wlll add $\$ 10$ a month from the time you began, and owe you $\$ 120$ when your time is up." Davls \& Co. discharged Morgan two or three weeks before the end of the term, because the latter had gone to Florlda for several days wlthout thelr consent. Morgan inslsts that he told Davls that he was golng and the latter made no objection. He clalmed that he was dlscharged without proper cause, and brought sult for the extra compensation promlsed. The jury found a verdict in hls favor, and, the court having refused to grant a new trlal, Davis \& Co. excepted.

If the promlse contemplated that Davls \& Co. were to pay Morgan $\$ 10$ per month for that part of the year which had al ready passed, and as to whlch there had been a settlement, It was manlfestly nudum pactum; for a past transaction, the obligation of whlch has been fully satisfled, will not sustain a new promise. Gay v. Mott, $43 \mathrm{Ga} .254$. And the result is practIcally the same whether Morgan or Davls was correct in the statement of the conversation. Both proved a promlse to give more than was due, and to pay extra for what one was already legally bound to perform. The employer, therefore, recelved no conslderation for hls promlse to give the additional money at the end of the year. Morgan had agreed to work for 12 months at the price promlsed, and if during the term he had agreed to recelve less, the employer would stlll have been llable to pay hlm the full $\$ 40$ per month. On the other hand, the employer could not be forced to pay more than the contract prlce. He got no more servlces that he had al ready contracted to recelve, and according to an almost unbroken line of decislons the agreement to glve more than was due was a nudum pactum, and vold, as having no conslderation to support the promlse. The case is something like that of Bush v. Rawlins, 89 Ga. 117, 14 S.E. 886, where the landlord agreed to glve the tenant certaln property if he would pay hls rent promptly; and it was held that such a promlse was a gratulty, and vold, as without consideration to support It. And see Tatum v. Morgan, $108 \mathrm{Ga} .336,33$ S.E. 940 (2); Civ. Code 1895, $\$ 3735$. It is also within the princlple of Stilk v. Myrick, 2 Campbell, 317, where Lord El lenborough held that an agreement to pay seamen extra for what they were bound by their articles to do was void. And so in Barlett v. Wyman, 14 Johns. 260, a similar rulling was made in a case where a master agreed to give more wages If the seamen would not abandon the shlp. See, also, Ayres v. C. R. I. Ry. Co., 52 lowa, 4783 N. W. 522. There are cases holding that a new promlse is blndlng where one of the parties to a contract refuses to perform, and, to save a loss, the innocent party agrees to pay more than the original contract price, If the actor wlll perform as originally agreed. Goebel v. Linn, $47 \mathrm{Mlch}$. 489, II N. W. 284, 41 Am. Rep. 723. But even if that line of cases should not be disregarded as tendling to encourage a breach of contract, they do not affect the rights of Morgan here, because he does not bring himself within thelr 
ruling. Had there been a rescission or formal cancellation (Vanderblit $v$. Schreyer, 91 N. Y. 402) of the old contract by mutual consent, and If a new contract wlth new terms had been made; or if there had been any change In the hours, services, or character of work, or other consideration to support the promise to pay the increased wages It would have been enforceable. But, as It was, Morgan proved that Davls promlsed to pay more for the performance of the old contract than he had orlglnally agreed. Such a promlse was not blnding.

It was argued that the moral obligation would support the promise here, and undoubtedly there are cases in which such consideration has been held to be sufflclent. For example, that arlsing from the duty of a father to support hls bastard chlld. Hargroves v. Freeman, $12 \mathrm{Ga}, 342$. At one time Lord Mansfield was quoted as having sald that all promises dellberately made should be held binding, but Lord Denman, In Eastwood v. Kenyon, II Adol. \& E. 438, attempts to show that this was elther a misquotation, or that, If such a doctrine could have been deduced from whatever he sald, the court had refused to follow It in Littlefleld v. Shee, 2 Barn. \& Ad. 81l. The cases holding In conformity with Lord Mansfleld's supposed statement, while set out in Hergrove $v$. Freeman, supra, are not adopted as law, because the court finally held that the principle to be adduced from the general current of authoritles is that, for a moral obligation to constitute a sufficlent consideration to support an express promise, it must be founded upon an antecedent valuable conslderation, though respectable authority can be adduced on the "other side." In an agreement by one partner to pay the other for extra work (Gray v. Hamll, $82 \mathrm{Ga} .375,10 \mathrm{~S} . \mathrm{E} .205$, 6 L. R. A. 72); In the promise by a landlord to refund to tenant's money pald by them for worthless fertlilizer (Parrott v. Johnson, 61 Ga. 475); and In the agreement by a brother to account to a sister for her interest as an heir at law in land which he had Improperly Induced the father to convey (Brown v. Latham, $92 \mathrm{Ga} .280,18 \mathrm{~S}$. E. 421)--the court recognlzed that there was a moral obligation to support the promlse, but in each of the cases there was something very close akin to a legal obligation or to a trust. In Plttman v. Elder, $76 \mathrm{Ga}$. 371, It was shown that an agreement to pay a debt barred by the statute of $1 \mathrm{imltatlons,} \mathrm{or} \mathrm{discharged} \mathrm{in} \mathrm{bank-}$ ruptcy, was not supported by what was formerly called a "moral obiligation," but by the antecedent obligation; the new promise to pay amounting simply to a walver of the statute or of the dlscharge. Clv. Code 1895, $\$ 3658$, defines a good consideration to be such as is founded on natural duty and affection or "on a strong moral obligation." In the light of the authorltles, however, the strong moral obllgation here referred to seems to be one supported elther by some antecedent legal obligation, though unenforceable at the time, or by some present equitable duty. The sectlon, however, does not relate to the moral obligation. which inheres in every promise. Austell $v$. Humphries, $99 \mathrm{Ga} .416,27 \mathrm{~S} . \mathrm{E} .736$. While all courts recognize the obligation arlsing from any undertaking, they are, from the necessity of the case, forced to hold that naked promises must depend for their performance solely upon the wlll of the promisor, and not upon the tribunals whlch are organlzed to perform the "duty of government to protect person and property," and in pursuance thereof to award money damages for breaches of contracts. Clv. Code 1895, $\$$ 5699. But they cannot enforce promlses binding on the consclence, except in those cases where some pecunlary 
damage flows from the breach, or where, in addition to the moral obligation, the promlse is also supported by a consideration. When one recelves a naked promise, and such promlse is broken, he is no worse off than he was. He gave notbing for It, he has lost nothing by $1 t$, and on its breach he has suffered no damage cognlzable by courts. No benefit accrued to him who made the promlse, nor dld any injury flow to $\mathrm{hlm}$ who recelved $\mathrm{lt}$. Such promises are not made within the scope of transactions Intended to confer rights enforceable at law. They are IIghtly made, dlctated by generoslty, curtesy, or Impulse, often by rulnous prodigallty. To enforce them by a judgment in favor of those who gave nothlng therefor would often bring such imperfect obligations into competition with the absolute duties to wife and chlldren, or Into competition wlth debts for property actually recelved, and make the law an instrument by whlch a man could be forced to be generous before he was just. Both under the clvil and the common law, courts were prohibited from enforclng contracts without consideration, and relegated the performance of such promlses solely to those who made them.

Judgment reversed. All the Justices concurring, except LUMPKIN, P. J., absent on account of slckness.

\section{NOTES}

The doctrine of conslderation will be taken up later. simply stated, it means that an agreement is unenforceable unless the promisee confers a benefit on the promisor or Incurs a detriment as the inducement to the promlse. Gratultous promises, that is, promlses unsupported by considoration, are not enforceable in law. Is not the law of contracts itself placing a restriction upon the freedom to contract? Why shouldn't Davis \& Co. "s promise to pay Morgan a larger salary be enforced?

On the other hand, is not thls case like the wolf case in that there: is an element of duress? Suppose that an employer had sought out a certaln englneer to develop a new process. Suppose further that the employer had hil red the engl neer under a five year contract. After the first year, the englneer, knowlng that the employer could not afford to let him go, informs the employer that unless the employer increases his salary substantially, he, the englneer, wlll qult. The employer agrees to the increase, but then refuses to pay the engineer the additlonal amount after the engineer performs. Should the engineer be able to enforce the agreement for the additional salary?

A final restriction, which is similar to consideration restriction, involves the requirement that certain contracts, though valid, will not be enforced unless. there is a written memorandum evidencing the agreement and signed by the party against whom enforcement is sought. The law requirIng a writing is known as the Statute of Frauds. Included within the statute are contracts for the sale of land, contracts whlch cannot be performed within one year, contracts for the sale of goods for a price in excess of a certaln amount. An llilustration of this is found in section 2-201 of the Uniform Commercial Code:

88. 
(1) Except as otherwise provided in this section a contract for the sale of goods for the price of $\$ 500$ or more is not enforceable by way of action or defense unless there is some writing sufficlent to Indlcate that a contract for sale has been made between the partles and slgned by the party agalnst whom enforcement is sought or by hls authorlzed agent or broker. A writing is not insufficlent because it omits or Incorrectly states a term agreed upon but the contract is not enforceable under this paragraph beyond the quantity of goods shown in such writing.

\section{FULLER AND R. BRAUCHER, BASIC CONTRACT LAW (1964) 796:}

\section{SECTION 3.--THE PURPOSE OF THE STATUTE}

When a legislature says that the valldity of a transactlon depends upon the observance of certain formalities, this requil rement may be imposed for a varlety of reasons. Some of these have been suggosted in the readings prevlously presented under the title, "The Function of Legal Formalitles" (supra, pp. 151-155). In contract law, Austin discerned two princlpal reasons for requiring formalities: 1) "to provide evidence of the existence and purport of the contract, In case of controversy," and 2) "to prevent inconsiderate engagements." Was the Statute of Frauds Intended to serve both of these purposes or only the first?

Certalnly It was intended to serve the first. It was an act to prevent "frauds and perjurles" and stated in Its preamble that it was almed at "many fraudulent practlces which are commonly endeavored to be upheld by perjury, and subornation of perjury." To handicap the plaintiff who might seek to establish a contract by perjured testimony, the statute required him to found hls case on a written memorandum signed by the defendant. In this respect the purpose of the statute was evidentlary. It sought a trustworthy memorlal of the transaction and 1 ts terms.

On the other hand, it is clear that the Statute could also have had another purpose, that which Austin described as preventing "Inconsiderate engagements." When a man cannot be bound untll he has slgned a writIng, a procedure has been establlshed that wlll tend to prevent hlm from sllpping into a legal undertaking without a full appreclation of what he is dolng. The writing serves as a warning or deterrent agalnst hasty action.

If the draftsmen of the statute of Frauds had this second object in mind, they have left no track of it in the historlcal records of the time or in the language of the act they drew. On the other hand, the judges who have interpreted the statute have occasionally assumed that it had as a collateral and secondary purpose that of Insuring dellberation in the making of contracts. Thus the court in Warden $\dot{v}$. Joñes, 1857, 2 De. Gex \& J. 76, 83-84, sald:

"The law has .. . wlsely forbldden [oral proof of contracts in conslderation of marriage; Section $4(3)$ supra]. Persons are so likely to be led Into such promlses inconsiderately, that the law has wisely required them to be manlfested by writing..." 
Expresslons tending toward the same thought will be found in cases involving other sections of the Statute, particularly the "suretyship" section. (Section 4(2), supra \$2.)

On the other hand, there are holdings that can be justifled only on the vlew that the sole purpose of the Statute is to insure rellable evldence of the contract. Thus, a number of cases have held that a letter settling forth the agreement but repudlating it may serve as a memorandum to charge the writer of the letter. (C 8 .511; W 5 579; RSC 8 209.) 
The Substance of a Promlse

Since the law of contracts is concerned with promises, it is necessary to consider what constitutes a promise. The II ne between promise, prediction and statement of fact is not always clear, and some concepts such as warranty have plcked up special meaning to the lawyer. Conslder the following materials.

Section 2 of the Restatement of Contracts 11

SEC. 2. PROMISE; PROMISOR; PROMISEE; BENEF ICIARY.

(1) A promise is a manifestation of intention to act or refrain from acting in a speclfled way, so made as to justify a promisee in understanding that a commitment has been made.

(2) The person manifesting the Intention is the promisor.

(3). The person to whom the manlfestation is addressed is the promisee.

(4) Where performance will benEfit a person other than the promisee, that person is a beneficlary.

Comment:

a. Acts and resulting relations. "Promise" as used In the Restatement of this Subject denotes the act of the promlsor. If by virtue of other operative facts there is a legal duty to perform, the promise Is a contract; but the word "promise" is not $11 \mathrm{mited}$ to acts having legal effect. Like "contract," however, the word "promise" is commonly and quite properly also used to refer to the complex of human relations which results from the promisor's words or acts of assurance, including the justified expectations of the promisee and any moral or legal duty which arises to make good the assurance by performance. The performance may be speclfled elther in terms describing the action of the promisor or in terms of the result whlch that action or inaction is to bring about.

b. Manlfestation of intention. Many contract disputes arise because different people atfach different meanings to the same words and conduct. The phrase "manlfestation of intention" adopts an external or objectlve standard for Interpreting conduct; it means the external expression of intention as distinguished from undisclosed intention. A promisor manifests an intention if he belleves or has reason to belleve that the promisee will infer that intention from his words or conduct. Rules governing cases where the promisee could reasonably draw more than one inference as to the promisor's intention are stated in connection with the acceptance of offers (see Secs. 21 and $2 \mid A$ ), In Chapter 9 on the scope and meaning of contracts, and In Chapter 17. on mistake.

c. Promise of action by third person; guaranty.

Words are often used which in terms promise action or Inaction by a third person, or which promise a result obtainable only by such action. Such 
words are commonly understood as a promise of conduct by the promisor which will be sufficlent to bring about the action or inaction or result, or to answer for harm caused by fallure. An example is a guaranty that a third person will perform his promise. Such words constitute a promise as here defined only If they justify a promlsee in an expectation of some action or inaction on the part of the promisor.

d. Promise of event beyond human control; warranty.

Words which in terms promise an event not within human control are ordinarlly to be interpreted as a promise to answer for harm caused by the fallure of the event to occur. An example is a warranty of an existing or past fact, such as a warranty that a horse is sound, or that a ship arrived in a forelgn port some days previlousiy. Such promises are often made when the parties are ignorant of the actual facts regarding whlch they bargain, and may be dealt with as if the warrantor could cause the fact to be as he asserted. It is then immaterlal that the actual condition of affairs may be Irrevocably fixed before the promise is made.

Words of warranty, like other conduct, must be interpreted in the light of the clrcumstances and the reasonable expectations of the partles. In an insurance contract, a "warranty" by the insured is usually not a promise at all; It may be merely a representation of fact, or, more commonly, the fact warranted is a condition precedent to the Insurer's duty to pay (see Sec. 260). In the sale of goods, on the other hand, a simllar warranty normally also includes a promise to answer for damages (see Uniform Commerclal Code Sec. 2-715).

\section{Illustratlons:}

1. A, the bullder of a house, or the inventor of the material used in part of its construction, says to $B$, the owner of the house, "I warrant that this house wlll never burn down." Thls is in effect a promise to pay for harm If the house should burn down.

2. A, by a charter-party, undertakes that the "good ship Dove A I," having salled from Marsellles a week ago for New York, shall take on a cargo for $B$ on her arrival in New York. The statement of the quality of the ship and the statement of her time of salling from Marseilles are in effect promises to pay for harm if the statement is untrue.

e. Lllusory promises; mere statements of intention.

Words of promise which by their terms make performance entirely optional with the "promisor" whatever may happen, or whatever course of conduct in other respects he may pursue, do not constitute a promise. Although such words are often referred to as forming an lillusory promise, they do not fall within the present definition of promise. They may not even manifest any intention on the part of the promisor. Even if a present intention is manifested, the reservation of an option to change that intention means that there can be no promisee who is justifled in an expectation of performance. 
On the other hand, a promise may be made even though no duty of performance can arise unless some fact exists or some event occurs (see Sec. 250). Such a conditional promise is no less a promise because there is small Ilkel ihood that any duty of performance will arise, as in the case of a promise to Insure against fire a thoroughly fireproof building. There may be a promise in such a case even though the duty to perform depends on a state of mind of the promisor other than his own unfettered wish (see Sec. 265), or on an event within the promisor's control.

\section{Illustration:}

\section{A says to $B$, "I will employ you for a year at a} salary of $\$ 5,000$ if I go into business." This is a promise, even though it is wholly optional with A to go into business or not.

f. Opinions and predictlons. A promise must be distinguished from a statement of oplnion or a mere prediction of future events. The distinction is not usually difficult in the case of an informal gratultous opinion, since there is often no manifestation of Intention to act or refrain from acting or to bring about a result, no expectation of performance and no consideration. The problem is frequently presented, however, whether words of a seller of goods amount to a warranty. Under Uniform Commerclal Code Sec. 2-3I3(2) a statement purporting to be merely the seller's opinion does not create a warranty, but the buyer's rellance on the seller's sklll and Judgment may create an implied warranty that the goods are fit for a particular purpose under Uniform Commercial Code Sec. 2-315. In any case where an expert opinion is paid for, there is likely to be an implled promlse that the expert will act with reasonable care and skill.

A promise often refers to future events which are predicted or assumed rather than promised. Thus a promise to render personal servlce at a particular future time commonly rests on an assumption that the promisor wlll be alive and well at that time; a promise to palnt a building may similarly rest on an assumption that the building wlll be in existence. Such cases are the subject of Chapter 14 on Impossibility. The promisor may of course promlse to answer for harm caused by the fallure of the future event to occur; If he does not, such a fallure may discharge any duty of performance.

\section{III ustration:}

4. A, on seeing a house of thoroughly fireproof construction, says to $B$, the owner, "This house will never burn down." This is not a promise but merely an opinion or prediction. If $A$ had been paid for his opinion as an expert, there might be an implied promise that he would employ reasonable care and sklll in forming and glving his opInion.

Restatement of Contracts I defined "promise" as "an undertaking, however expressed, elther that something shail happen, or that something shall not happen, In the future." Is the definition In Restatement 11 an Improvement? Why? Consider the following excerpt from Gardner, An Inquiry into the Princlples of Contract, 46 Harv. L. Rev. 1, 4 (1932). 
The reader can doubtless recognize a promise without the ald of definition; but since we are to study its consequences a brief survey of its characterlstics is required. In the first place, a promise does not differ from other predictions elther in the fact that it arouses expectations or in the strength and precision of the expectations that are aroused. Cltizen A opens hls morning paper and learns that astronomer $X$ says that there will be an eclipse of the sun visible in a nelghboring clty on August 31, 1932, beginning at 3:29:17 p.m. He also learns that candidate $Y$ says that he will, If elected, reduce the mUnlcipal payroll and pay no regard to party services or afflllations in appointments to municlpal posts. Citizen A probably has complete confidence in the fulfillment of astronomer $X ' s$ predlction, and he may or may not have confidence In the assurance of candidate $Y$. But, whether his faith in candidate $Y$ is large or little, he would probably speak of his assurance as a promise, a name which he would never think of applying to the prediction of astronomer $x$. What, then, is the essentlal difference between these two predictlons? It seems to lie in the character of the causal relationshlp asserted between the fact predicted and the prediction itself. Astronomer $X$ says that he makes his statement because he is compelled to make it by the facts. Candidate $Y$ says that certain events will happen because they are compelled to happen by his word. Either statement may be true; events may prove el ther to be false. The essence of a promise is that it asserts the power of the speaker's mind over the future; a prediction asserts the power of the future over the speaker's mind.

Either kind of assertion may, of course, be conditional, that is, limited by one or more contingencles whlch are neither promised nor foretold. Candidate $Y^{i}$ s promise is conditional on his election, and the prediction that an eclipse will be visible in a certain city is conditional on the absence of clouds. And it is to be observed that every promise is always conditional on one contingency whlch is nelther promised nor predicted, namely, on an act of wlll by someone other than the promisor. A man may vow himself to Ilfelong cellbacy, to the pursult of medlcine, or to the discovery of the North Pole, and thereby affirm the power of his present wlll over all his future conduct in the most emphatic terms. But such assertions are not promises, at least not in any sense which concerns the common law. To be of interest to lawyers a promise must concern at least two persons; it must assert not only that the speaker has a power over the future but that he confers a part of this power on someone else. We may therefore, propose the following tentative definition:

A promise is an assertion that someone other than the speaker possesses, by force of the assertion, some power over the future whlch he did not previously possess.

It would be Interesting to compare thls with the American Law Institute's definition and to examine their respective merits and defects. That discussion, however, must be reserved for another place. For the present it is sufficlent to point out that the definition here submitted has at least the practical advantage of yielding, by Implication, a definition of "proml see": 
A promisee is a person to whom the speaker attributes some power which is asserted by the promlse to exist.

The term "promisee" is not defined in the Restatement, and to the present writer it does not seem easy to determine in precisely what sense that term is used.

We must now notice two of the most persistent sources of difficulty in the law of contracts: first, the fact that words frequently mean different things to the speaker and to the hearer; second, the fact that promise and prediction are often Inextrlcably mixed up in the same phrase.

When mercant A promises to merchant B that he will dellver 125 bales of cotton "ex Peerless," both partles understand this as an assertion that $B$, by virtue of the promise, possesses a power to command cotton which he did not prevlously possess. But to $A$ this may mean a power to obtain cotton from a ship which salled from Bombay In October, while to B it may mean a power to obtaln cotton from an entirely different vessel which left Bombay two months later. There are, In fact, two distinct assertions--the one uttered and the one heard--and legal consequences may concelvably be predicated on elther, on neither, or on both. This becomes vividly apparent whenever partles are negotiating at a distance so that the utterance and the hearing are separated by an appreclable Interval of time. Most of the controversies which have arlsen from this kind of situation revolve about the question whether the utterance or the hearing of some promise is to be given controlling force.

Even if both $A$ and $B$ refer to the same Peerless, $A^{\prime}$ s assertion is a compound of promise and prediction; B's power to command cotton is asserted to exist partly because A's word binds him to a certain course of conduct and partiy because $A$ expects the Peerless to arrive. No one understands A to assert, however, that the Peerless will come in because he promises that it wlll. That part of his assertion is a prediction of the same order as that of astronomer $X$. The promissory part of an assertion about the future is confined to that portion of the events predicted which are asserted to be under the promisor's control.

It will be convenient to pause at this point to define four phrases which wlll be used henceforth throughout this essay as terms of art. By "apparent promlse" is meant the promise as heard and understood by the promisee--in the IIllustrative case just stated the promise to delliver cotton from that Peerless which salled in October from Bombay. By "actual promlse" is meant the promise as uttered and understood by the promisor--the promise to delliver cotton from the December Peerless. By "power predicted" is meant the entire power which any expression elther wholly or partly promissory attributes to the promisee--In our III ustration the power to obtain cotton at the time when the deslgnated vessel would normally arrive. By "power asserted" is meant that portion of the power predicted which the promlsor purports to be creating by force of the promissory utterance. In the llilustrative case the power asserted is limited by the continued existence of the cotton and possibly by other facts as well. 
So much for the anatomy of a promise. Let us now consider its function, for the characteristics that make it a useful instrument in the conduct of affairs. To the promisor the chlef importance of a promise may often reslde in lts consequences to his own moral integrity and self-respect. But to others its chlef importance is in its value, and by this is meant its value to the promisee. The value of a promise is the product of two factors: (i) the value of the power predicted, measured by the promisee's desire for It, and (2) the credit of the promise, measured by the promisee's faith that the promisor's assertions and predictions will prove true. The value of the power predicted rather than of the power asserted is properly taken as the first factor, first, because the promisee is normaliy not conscious of any difference between them, secondly, because even if he is conscious of such difference he bases his economic calculations on the assumption that it is the expected which will happen and that he will possess not merely the power asserted but the predicted power as well. As for the second factor: the extended debate which has revolved about the question of how one promise can serve as conslderation for another seems frequentiy to proceed on the concealed assumption that the credit of a promise is derived from the prospect of being able to bring a suit upon $1 t$ and that the value of a promise is therefore conferred upon it by the law. In this assumption a modicum of truth seems to be compounded with a large alloy of error. The credit of a promise results from the promisee's bellef that the promisor will be both able and willing to perform it; and whlle this. belief may perhaps be strengthened in some cases by the promisee's knowiedge that he has the coercive weapon of a lawsuit in his pocket, the smaller the importance of this factor the higher the credit of the promise is apt to be.

Finally, it should be noted that every promise has a cost, or negative value, to the promisor, dependent on the expected cost of performance and the probabliity that it wlli have to be performed. But unless the promise is for the payment of money this cost need not be equal to the positive value of the promise to the promisee, and it is possible that the cost and vaiue may differ very widely in amount.

Consider whether the following statements be "promises" under Restatement I or under Restatement II:

1. A on seeing a house of thoroughly fireproof construction says to $B$, the owner, "This house will never burn down."

2. A, the bullder of a house, or the inventor of the material used in part of its construction, says to $B$, the owner of the house, "I warrant that this house will never burn down." This is in effect a promise to be answerable for any proximate harm if the house should burn down; ..

3. A, by a charter-party undertakes that the "good ship Dove A I," having sailed from Marseilles a week ago for New York, shall take on a cargo for $B$ on her arrival in New York.

4. A. says to $B$, "I will employ you for a year at a salary of $\$ 5000$ if I go into business."

5. A says to $B$ that he will employ him for a fixed term at such salary as $A$ sees fit to pay. 
In Illustration I of Restatement 11, why Is the conclusion stated In terms of a promise to pay for harm if the house burns? is this the "promlse" that A makes or is it the promlse that the law holds him to? Can the law give any other remedy for breach of this promlse?

\section{Hawkins v. McGee}

\section{N.H. I14, $146 \mathrm{~A}+\mathrm{I} .641(1929)$}

Assumpsit against a surgeon for breach of an alleged warranty of the success of an operation. Trial by jury. Verdict for the plalntiff. The writ also contained a count in negligence upon whlch a nonsuit was ordered, without exception.

Defendant's motions for a nonsuit and for a directed verdlct on the count in assumpsit were denled, and the defendant excepted. During the argument of plaintiff's counsel to the jury, the defendant clalmed certain exceptions, and also excepted to the denlal of his requests for instructions and to the charge of the court upon the question of damages, as more fully appears in the opinion. The defendant seasonably moved to set aside the verdlct upon the grounds that it was (1) contrary to the evidence; (2) agalnst the weight of the evidence; (3) against the welght of the law and evidence; and (4) because the damages awarded by the jury were excessive. The court denled the motion upon the first three grounds but found that the damages were excessive, and made an order that the verdict be set aside, unless the plalntiff elected to remit all in excess of $\$ 500$. The plaintiff having refused to remit, the verdict was set aside "as excessive and agalnst the welght of the evidence," and the plaintiff excepted.

The foregolng exceptions were transferred by Scammon, J. The facts are stated in the opinion.

Ovide J. Coulombe and Ira W. Thayer, both of Berlin, for plaintiff.

Matthew J. Ryan and Crawford D. HenIng, both of BerlIn, for defendant.

BRANCH, J. I. The operation in question consisted in the removal of a considerable quantity of scar tissue from the palm of the plaintiff's right hand and the grafting of skln taken from the plaintlff's chest In place thereof. The scar tissue was the result of a severe burn caused by contact with an electrlc wire, which the plaintiff received about nine years before the time of the transactlons here involved. There was evidence to the effect that before the operation was performed the plaintiff and his father went to the defendant's office, and that the defendant, in answer to the question, "How long will the boy be in the hospital?" replled, "Three or four days, not over four; then the boy can go home and It will be just a few days when he wlil go back to work with a good hand. Clearly, this and other testimony to the same effect would not justify a finding that the doctor contracted to complete the hospital treatment in three or four days or that the plaintiff would be able to go back to work wlthin a few days thereafter. The above statements could only be construed as expressions of opinion or predictions as to the probable duration of the treatment and plaintiff's resulting disability, and the fact that these estimates were 
exceeded would impose no contractual $/$ lab $/ 1 /$ ty upon the defendant. The only substantlal basls for the pialntiff's claim is the testimony that the defendant also sald before the operation was decided upon, il will guarantee to make the hand a hundred per cent perfect or a hundred per cent good hand." The plaintlff was present when these words were alleged to have been spoken, and, if they are to be taken at their face value, It seems obvious that proof of their utterance would establish the glving of a warranty in accordance with his contention.

The defendant argues, however, that, even if these words were uttered by him, no reasonable man would understand that they were used with the intention of entering "Into any contractual relation whatever," and that they could reasonably be understood only "as his expression. In strong language that he believed and expected that as a result of the operation he would glve the plaintiff a very good hand." It may be conceded, as the defendant contends, that, before the question of the maklng of a contract should be submitted to a jury, there is a preliminary question of law for the trial court to pass upon, 1.e. "whether the words could possibly have the meaning imputed to them by the party who founds his case upon a certain interpretation," but it cannot be held that the trlal court declded this question erroneously in the present case. It is unnecessary to determine at this time, whether the argument of the defendant, based upon "common knowledge of the uncertainty which attends all surgical operations," and the Improbabllity that a surgeon would ever contract to make a damaged part of the human body "one hundred per cent perfect," would, In the absence of countervalling considerations, be regarded as conclusive, for there were other factors in the present case whlch tended to support the contentlon of the plaintiff. There was evidence that the defendant repeatedly sollclted from the plaintiff's father the opportunity to perform this operation, and the theory was advanced by plalntiff's counsel in the cross-examination of defendant that he sought an opportunity to "experiment on skin grafting," In whlch he had had little prevlous experlence. If the jury accepted this part of plaintiff's contention, there would be a reasonable basls for the further conclusion that, if defendant spoke the words attributed to him, he did so with the intention that they should be accepted at their face value, as an Inducement for the grantIng of consent to the operation by the plaintitf and his father, and there was ample evidence that they were so accepted by them. The question of the making of the alleged contract was properly submitted to the jury.

2. The substance of the charge to the jury on the questlon of damages appears in the following quotation: "If you find the plaintiff entltled to anything, he is entitled to recover for what pain and suffering he has been made to endure and for what Injury he has sustalned over and above what Injury he had before." To this instruction the defendant seasonably excepted. By it, the jury was permitted to consider two elements of damage: (1) Pain and suffering due to the operation; and (2) positive 111 effects of the operation upon the plaintiff's hand. Authority of any speclfic rule of damages in cases of this kind seems to be lacking, but, when tested by general principle and by analogy, It appears that the foregolng Instruction was erroneous.

"By 'damages,' as that term is used in the law of contracts, is intended compensation for a breach, measured in the terms of the contract." Davis 
v. New England Cotton Yarn Co., 77 N.H. 403, 404, 92 A. 732, 733. The purpose of the law is "to put the plaintiff In as good a position as he would have been in had the defendant kept his contract." 3 Williston Cont. Sec. 1338; Hardie-Tynes Mfg. Co. v. Easton Cotton 011 Co., 150 N.C. 150, 63 S.E. 676, 134 Am. St. Rep. 899. The measure of recovery "is based upon. What the defendant should have given the plaintiff, not what the plaintlff has given the defendant or otherwise expended." 3 Williston Cont. Sec. 1341. "The only losses that can be said falrly to come withln the terms of a contract are such as the parties must have had in mind when the contract was made, or such as they either knew or ought to have known would probably result from a fallure to comply with its terms." Davis $v$. New England Cotton Yarn Co., 77 N.H. 403, 404, 92 A. 732, 733, Hurd v. Dunsmore, 63 N. H. 171 .

The present case is closely analogous to one in which a machine is bullt for a certain purpose and warranted to do certain work. In such cases, the usual rule of damages for breach of warranty in the sale of chattels is applled, and it is held that the measure of damages is the difference between the value of the machine, if it had corresponded with tho warranty and its actual value, together wlth such incidental losses as the partles knew, or ought to have known, would probably result from a failure to comply with its terms. Hooper v. Story, 155 N.Y. 171, 175, 49 N.E. 773; Adams Hardware Co. v. Wimblsh, 201 Ala 548, 78 So. 902; Isaacs v. Jackson, etc., Co., 108 Kan. 17, 193 P. 1081; Paducah Hosiery Mills Co. v. Proctor, 210 Ky. 806, 276 S.W. 803; Ploneer Co. v. McCurdy, 151 Minn. 304, 186 N.W. 776; Chrlstian, etc., Co. v. Goodman, 132 Miss. 786, 96 So. 692; Hardle, etc., Co. v. Easton, etc., Co., 150 N.C. 150, 63 S.E. 676, 134 Am. St. Rept. 899; York Mfg. Co. v. Chelten, etc., Co., 278 Pa. 351, 123 A. 327; General Motors, etc., Co. v. Shepard Co., 47 R.1. 88, 129 A. 825; Cavanagh V. Stevens Co., 24 S.D. 349,123 N.W. 681 ; Foutty v. Chalmax Co., 99 W.Va. 300, 128 S.E. 389.

The rule thus applled is well settled in this state. "As a general rule, the measure of the vendee's damages is the difference between the value of the goods as they would have been if the warranty as to quality had been true, and the actual value at the time of the sale, including gains prevented and losses sustalned, and such other damages as could be reasonably anticlpated by the parties as Ilkely to be caused by the vendor's fallure to keep his agreement, and could not by reasonable care on the part of the vendee have been avolded." Union Bank v. Blanchard, 65 N.H. 21, 23, 18 A. 90 , 91; Hurd V. Dunsmore, supra; Noyes V. Blodgett, 58 N.H. 502 ; P.L. ch. 166, Sec. 69, subd. 7. We therefore conclude that the true measure of the plaintiff's damage in the present case is the difference between the value to him of a perfect hand or a good hand, such as the Jury found the defendant promlsed $\mathrm{hlm}$, and the value of his hand in its present condltion, including any incldental consequences falrly within the contemplation of the parties when they made their contract. I Sutherland, Damages (4th Ed.) Sec. 92. Damages not thus I Imited, although naturally resulting, are not to be glven.

The extent of the plaintiff's suffering does not measure this difference in value. The pain necessarily incldent to a serlous surgical operation was a part of the contribution which the plaintiff was willing to make to his joint undertaking with the defendant to produce a good hand. It was a 
legal detriment suffered by him whlch constituted a part of the consideration given by him for the contract. It represented a part of the price which he was wllling to pay for a good hand, but it furnished no test of the value of a good hand or the difference between the value of the hand which the defendant promised and the one which resulted from the operation.

It was also erroneous and misleading to submlt to the jury as a seperate element of damage any change for the worse in the condition of the plaintiff's hand resulting from the operation, although this error was probably more prejudiclal to the plalntiff than to the defendant. Any such 111 effect of the operation would be included under the true rule of damages set forth above, but damages might properly be assessed for the defendant's failure to improve the condition of the hand, even if there were no evidence that its condition was made worse as a result of the operation.

It must be assumed that the trlal court, in setting aside the verdict, undertook to apply the same rule of damages which he had previously given to the jury, and since this rule was erroneous, it is unnecessary for us to conslder whether there was any evidence to justify his finding that all damages awarded by the jury above $\$ 500$ were excessive.

3. Defendant's requests for Instructions were loosely drawn, and were properly denied. A considerable number of Issues of fact were raised by the evidence, and it would have been extremely mls leading to instruct the jury in accordance with defendant's request No. 2, that "the only issue on which you have to pass is whether or not there was a special contract between the plalntiff and the defendant to produce a perfect hand." Equally inaccurate was defendant's request No. 5, which reads as follows: "You would have to find, in order to hold the defendant ll able in this case, that Dr. MCGee and the plaintiff both understood that the doctor was guaranteeing a perfect resuit from this operation." If the defendant said that he would guarantee a perfect result, and the plaintiff relled upon that promise, any mental reservations which he may have had are immaterial. The standard by which his conduct is to be judged is not internal, but external. Woburn Bank v. Woods, 77 N.H. 172, 89 A. 491; McConnoll v. Lamontagne, 82 N.H. 423, 425, 134 A. 718; Eleftherion v. Great Fallis Mfo. Co. 83 N.H. - - , 146 A. 172.

Defendant's request No. 7 was as follows: "If you should get so far as to find that there was a speclal contract guaranteeling a perfect result, you would still have to find for the defendant unless you also found that a further operation would not correct the disablility claimed by the plaintiff." In vlew of the testimony that the defendant had refused to perform a further operation, it would clearly have been erroneous to give this instruction. The evidence would have justifled a verdict for an amount sufficlent to cover the cost of such an operation, even if the theory underlylng this request were correct.

4. It is unlikely that the questions now presented in regard to the argument of plaintiff's counsel will arlse at another trial, and therefore they have not been considered.

New trlal.

MARBLE, J., did not slt; the others concurred. 
What promises did the physlclan make in relation to the operation? Why did the court not consider the representation that the boy could return to work In three or four days a promise? What was it? Could a reasonable man in the position of the boy or the boy's father have understood this as a "commitment?"

Can a promise be made with the understanding that it shall not be legally enforceable? Consider the following two cases.

Rose and Frank v. Crompton

2 K.B. 261 (1923)

In this case, a written agreement between two bus inessmen contained the following clause:

This arrangement is not entered into, nor is this memorandum written, as a formal or legal agreement, and shall not be subject to legal jurisidiction in the law courts elther in the United

States or England, but it is only a definite expression and record of the purpose and Intention of the three partles concerned to whlch they each honourably pledge themselves with the fullest confidence, based upon past business with each other, that it will be carried through by each of the three parties with mutual loyalty and frlendly cooperation. The contract was held not to be enforceable by a court action.

The Mabley \& Carew Co. V. Borded

129 Ohio St. 375, 195 N.E. 697 (1935)

Infra.

Notes

To what extent is a determination of whether an utterance is a promise dispositive of these cases? Apparentiy, a non-promise cannot be a contract, but what considerations go into a determination of whether a group of words constitutes a promise? Do rules like those in the Restatement help in making these determinations or do they merely solve the easy cases whlch could be as well solved by the application of common sense.

Consider the following case. Are there different gradations of promises? Is this an Instance of a "promise" that does not evidence a sufflclent "commitment" to be a promise in the ey"; of the law? Is the promise of the husband similar to those of one who offers to seit his automobile for a pittance because he is angry over the way in which. It is running, or who makes an offer to sell something in jest? To what extent is totality of the circumstances surrounding the words spoken a factor in determining whether a "promlse" has been made?

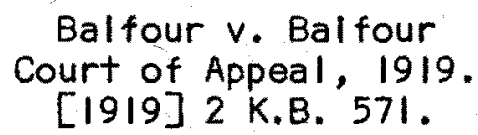

The plaintiff sued the defendant (her husband) for money which she claimed to be due in respect to an agreed allowance of $30 \mathrm{E}$ a month. The alleged agreement was entered into under the following clrcumstances. The 
partles were marrled In August, 1900. The husband a clvil engl neer, had a post under the Government of Ceylon as Director of Irrlgation, and after the marrlage he and his wIfe went to Ceylon, and IIved there together untll the year 1915, except that In 1906 they paid a short visit to this country, and in 1908 the wife came to England In order to undergo an operation, after which she returned to Ceylon. In November, 1915, she came to this country with her husband, who was on leave. They remained in England until August, 1916, when the husband's leave was up and he had to return. The wife however on the doctor's advlce remained in England. On August 8, 1916, the husband belng about to sall, the alleged parol agreement sued upon was made. The plalntiff, as appeared from the Judge's note, gave the following evldence of what took place: "In August, 1916, defendant's leave was up. I was suffering from rheumatic arthritis. The doctor advised my staylng In England for some months, not to go out tIll November 4 . On August 8 my husband salled. He gave me a cheque from 8 th to 31 st for 242 , and promlsed to give me 30.t per month till I returned." Later on she sald: "My husband and 1 wrote the figures together on August $8 ; 34 z$ shown. Afterwards he sald 30f." In cross-examination she sald that they had not agreed to live apart until subsequent differences arose between them, and that the agreement of August, 1916, was one which mlght be made by a couple in amity. Her husband in consultation wlth her assessed her needs, and sald he would send $30 \pm$ per month for her malntenance. She further sald that she then understood that the defendant would be returning to England In a few months, but that he afterwards wrote to her suggesting that they had better remain apart. In March, 1918, she commenced proceedings for restitution of conjugal rights, and on July 30 she obtained a decree nisl. On December 16, 1917, she obtalned an order for alimony.

Sargeant, J. held that the husband was under an obligation to support his wife, and the partles had contracted that the extent of that obligation should be defined in terms of so much a month. The consent of the wife to that arrangement was a sufficlent consideration to constitute a contract which could be sued upon.

He accordingly gave judgment for the plaintiff.

The husband appealed.

[The concurring op inions of Warrington, L. J,, and Duke, L. J., are omltted.]

ATKIN, L. J. The defence to this action on the alleged contract is that the defendant, the husband, entered into no contract with his wife, and for the determination of that it is necessary to remember that there are agreements between partles whlch do not result in contracts within the meaning of that term in our law. The ordinary example is where two parties agree to take a walk together, or where there is an offer and an acceptance of hospltality. Nobody would suggest in ordinary clrcumstances that those agreements result in what we know as a contract, and one of the most usual forms of agreement which does not constltute a contract appears to me to be the arrangements which are made between husband and wife. It is quite common, and it is the natural and Inevitable result of the relationship of husband and wife, that the two spouses should make arrangements between 
themselves--agreements such as are in dispute in this action--agreements for allowances, by which the husband agrees that he wlll pay to his wife a certaln sum of money, per week, or per month, or per year, to cover el ther her own expenses or the necessary expenses of the household and of the children of the marriage, and in which the wife promises either expressly or impliedly to apply the allowance for the purpose for which It is given. To my mind those agreements, or many of them, do not result in contracts at all, and they do not result in contracts even though there may be what as between other parties would constitute consideration for the agreement. The consideration, as we know, may consist elther in some right, interest, profit or benefit accrulng to one party, or some forbearance, detriment, loss or responsiblility given, suffered or undertaken by the other. That is a well-known definition, and it constantly happens, I think, that such arrangements made between husband and $w / f e$ are arrangements in which there are mutual promises, or in which there is consideration in form within the definition that I have mentloned. Nevertheless they are not contracts, and they are not contracts because the partles did not intend that they should be attended by legal consequences. To my mind it would be of the worst possible example to hold that agreements such as this resulted in legal obligations which could be enforced in the courts. It would mean this, that when the husband makes his wife a promise to give her an allowance of $30 \mathrm{~s}$. or $2 \mathrm{E}$. a week, whatever he can afford to give her, for the maintenance of the household and chlldren, and she promises so to apply it, not only could she sue hlm for his fallure in any week to supply the allowance but he could sue her for non-performance of the obllgation, express or implied, whlch she had undertaken upon her part. All I can say is that the small Courts of this country would have to be multiplied one hundredfold If these arrangements were held to result in legal obligations. They are not sued upon, not because the partles are reluctant to enforce their legal rights when the agreement is broken, but because the parties, in the inception of the arrangement, never intended that they should be sued upon. Agreements such as these are outside the realm of contracts altogether. The common law does not regulate the form of agreements between spouses. Their promises are not sealed with seals and sealing wax. The consideration that really obtains for them is that natural love and affection which counts for so little in these cold Courts. The terms may be repudlated, varled or renewed as performance proceeds or as disagreements develop, and the princlples of the common law as to exoneration and discharge and accord and satisfaction are such as find no place in the domestlc code. The parties themselves are advocates, Judges, Courts, sheriff's offlcer and reporter. In respect of these promises each house is a domaln into which the KIng's writ does not seek to run, and to which his offlcers do not seek to be admitted. The only question in this case is whether or not this promise was of such a class or not. For the reasons given by my brethern it appears to me to be plainly established that the promise here was not intended by elther party to be attended by legal consequences. I think the onus was upon the plaintiff, and the plaintiff has not established any contract. The parties were living together, the wife intending to return. The suggestion is that the husband bound himself to pay $30 \mathrm{t}$ a month under all circumstances, and she bound herself to be satisfied with that sum under all circumstances, and, although she was in ill-health and alone in this country, that out of that sum she undertook to defray the whole of the medlcal expenses that might fall upon her, whatever might be the development of her ill ness, and 
In whatever expenses it $\mathrm{mlght}$ Involve her. To my mind nelther party contemplated such a resuit. I think that the parol evldence upon which the case turns does not establish a contract. I think that the letters do not evidence such a contract, or amplity the oral evidence which was given by the wife, which is not in dispute. For these reasons I think the judgment of the court below was wrong and that this appeal should be allowed.

\section{Express Warranties and the UnIform Commerclal Code}

Contracts for the sale of goods are governed by Article 2 of the Uniform Commerclal Code which is a "code" or statute originally drafted by a group commlssloned by the Amerlcan Law Institute and the National Conference of Commissloners on Unlform State Laws. See the Introduction to the Uniform Commerclal Code and pages I through 9. The UCC has now been adopted by all states except Loulslana. Some states have, however, changed particular sections so that the law is not completely uniform throughout the country.

Since the UCC has been passed by several state leglslatures, it is binding on the courts. But, as is true with all statutes, the courts do have the power, and responsibility, of "Interpreting" the code. Thus, In a partlcular controversy brought before the court where the UCC is controlling, the court's must apply the UCC to the facts and determine the intent of the legislature in enacting the applicable provisions. Much has been written on the role of courts where a case is controlled by a statute and there wlll be reference to this question throughout the course. Inltially, it might be helpful to read the following article: Hart, UiCC Brlef No. 2: Interpreting the Unl form Commerclal Code, 12 Prac. Lawy. No. 7 p. $39(1966)$.

During the past decade, the fate of the Uniform Commerclal Code has been in the lap of state legislatures. Controversy has arlsen over its adoption and over amendments that would diminish its unl formity among the states and destroy its Internal consistency. Now that almost every jurisdiction has accepted the Code, Its protagonists have victory in slght and attention is shifting to the courts, whlch will manage its future and test the wisdom of its draftsmen and advocates.

A convincing argument can be made for the proposition that appellate declslons reflect primarlly those situations where little or no preventlve law was practlced. Accordingly, they may be a poor barometer of the Code's efflclency in expeditling the run-of-the-mlll business deal.

If businessmen, assisted by their lawyers, can arrange and plan their transactions so as to avold IItigation, then the Code is successful. It Is true that the Code wlll be tested by the commerclal communlty and the lawyer involved in counselling, but it must also be effective in settling disputes that arlse from the abnormal or just plain sloppy business deal. Once there is $11+$ igation, at least one of the parties is destined to realize less than he had expected when the bargaln was struck and the law must apportion the loss. 
Importance of Decided Cases

The effect of reported decisions goes beyond the settlement of disputes between the partles to the transaction. They will influence the legal communlty's satisfaction with the Code and they wlll affect sought-for uniformity of application among the states.

The narrow decision in a reported case is quickly extended by the bar to other siml lar situations. The rationale of the opinion is used as a gulde to future planning of commerclal transactions and to predict the path that the law is travelling.

The uniformity of the Code upon uniform interpretation in the adopting states. An undesirable decision leaves courts in sister states the unattractlve cholce of perpetuating a mistake or of adopting a different interpretation that cuts into the sameness of the code.

Just as the Code establishes rules of law for society, the cases decided under the Code will establish rules of law. The courts wlll flll the gaps and declde questions that the leglsiature obviously did not conslder. In another decade we will be talking about the "Uniform Commerclal Code as Interpreted," and the body of commerclal law will again be declsiona! as well as statutory.

\section{Attitude of Courts}

There is some reason to be apprehensive about the fate of the Uniform Commerclal Code as it enters judiclal arenas. On the whole, American courts have not been very successful in dealing with statutes. The great talent and sklll that Anglo-American lawyers and judges exhibit in the very difficult art of discovering and using case law makes their general ineptitude in using statutory material difficult to understand.

It would seem that the abllity to analyze cases by extracting issues, by differentiating between dicta and ratio decidendi, by utllizlng a court's rationale to limit or expand the consequences of a decision, and by using dissimilar case patterns to formulate an argument and the synthesls of a body of tort or contract law out of the myriad reports of litigation is a much more exacting intellectual task than the interpretation of statutory rules. Yet Karl Llewellyn, an almost unrestrained admirer of the "common law tradition," found our system still wanting in its abllity to cope adequately with statutory problems.

\section{Role of Court vis-à-vis Legislature}

Several writers have polnted to the tendency of American courts to overemphasize the valid proposition that the legislature is the supreme lawmaker as the baslc cause of thls difflculty. These same wrlters have inslsted that courts must recognize their role as lawmakers even where the legislature has acted.

This does not mean that the courts may overrule a statute where their judgment differs from that of the legislature, but it does mean that courts should accept the legislative rule much in the same way as they accept 
case-rules from declsions previously reported. Reflection upon the number of cases where a court has overruled a prlor case indlcates the narrow area In whlch a court might even be tempted to decide directly contrary to the wording of a statute.

The arguments of these writers wlll not be repeated here. Thelr conclusions are accepted. If legislative-made rules are to operate the same as court-made rules, the role of the court in interpreting or construing statutes is not much different from its place in declding cases where no statute is involved.

This is the touchstone of the Unlform Commerclal Code. Although it contalns llteraliy hundreds of rules to govern commercial transaction litigation, stlll it recognizes, probabiy more than any other statute, the continuing need for development of the law. Consequently, it affords the courts the opportunity for expanding its provisions.

$$
\text { Section } 1-102
$$

It is easy to neglect the importance of section 1-102 which states the purposes of the code and rules for its construction. The section states that the Code "shall be Ilberally construed and applied to promote Its underlying purposes and pollcles."

\section{Purposes}

The stated purposes are:

To simplify, clarify, and modernize the law governing commercial transactlons;

To permit the continued expansion of commerclal practices

through custom, usage, and agreement of the parties; and

To make unlform the law among the various jurisdlctions.

\section{Official Comment}

The necessary generality of these commands seemlngly makes the section of little practical or concrete use.

Nor does the Officlal Comment to the section appear to help. It states that:

This Act is drawn to provide flexibllity so that, since it is intended to be a semi-permanent plece of legislation, it will provide its own machinery for expansion of commercial practices. It is intended to make it possible for the law embodied in this Act to be developed by the courts in the light of unforeseen and new clrcumstances and practices. However, the proper construction of the Act requires that Its interpretation and application be $11 \mathrm{mited}$ to $i$ ts reasons. 
Emphas is

In spite of its generality, this section (and the accompanying Comment) affords the advocate and the judge a key to interpretation of the code. It tells, and in statutory language that is Itself a command, how the Code draftsmen belleved their act should be handled by the courts.

Speclfically, the section emphaslzes:

The polley behind the varlous rules;

The need for Improvisation by the courts in those cases, which will be the vast majorlty of Iltigated disputes, where the Code provides no specific clear-cut answer to the issue presented; and

The desirabillty of uniform construction among the states.

\section{Sources of Polley}

How a court flllis a gap in the Code, or provldes for changes in commerclal practlces, will be determlned to a large extent by Its understanding of the policy behind those sections of the Code that are analogous or simllar to the issue presented. It wlll also be determined, to a lesser extent, by the importance that the court puts upon uniformity. Several comments are appropriate concerning the methods that can be applied when search Ing for pollcy, since the Code provides some distinct avenues of approach that are unique to American statutes.

Official Comments

The draftsmen of the Code have written Comments to each of its sections. These are reprinted in most compllations, state codes, and services that reproduce the Code. They are not statutory language because they were not passed by the legislature of any state, nor are they legisiative history because they were not necessarliy considered by state legislatures. They have great utility and Importance In construing the Code, however, as they do present a commentary by the draftsmen on the purposes, policles, and intent of the various sections.

In the 1952 draft of the Code, section 1-102(3)(f) specifically provided that the Comments "may be consulted in the construction and application of this Act but if text and comment conflict, text controls." This sectlon was omitted from the 1958 and subsequent editions of the Code. The reason given by the draftsmen for its omission was simply that, at the time the 1958 edition was first released, the new comments were not completed.

It would seem that the splrit of former section $1-102(3)(f)$ should continue to prevail in use of the Comments.

Drafting HIstory

The first Integrated draft of the Uniform Commerclal Code was released by The American Law Institute and the Natlonal Conference of Commissioners 
on State Laws In 1949. Thls draft was never approved by the bodles of these two institutions, and numerous changes were made before the second draft was released In 1952. The 1952 draft was approved by the Amerlcan Law Institute and the Natlonal Conference. It was also Indorsed by the American Bar Association. Changes were again made In 1953, 1957, 1958, and 1962. Changes in a statute are famlliar tools of statutory construction, but there are some peculiarlties surrounding the Code that should be noted.

In the first place, the changes referred to were not made by the states (although most of the states that adopted the Code early subsequently amended their Code to accord wlth the changes made by the draftsmen). They were made by The Amerlcan Law Institute and the Natlonal Conference commlttees working on the Code. Hence, this is not leglslative history in the tradltlonal sense. However, the changes may often, though not always, throw light on the current Code provisions.

Secondly, it should be mentioned that the 1949 draft was somewhat prematurely released for reasons unconnected with its completion. Thus changes made from 1949 to 1952 are not necessarlly indlcative of any new thinking.

FInally, perhaps more valuable than the changes themsel ves are the comments of the draftsmen that accompany the alteratlons. These were orlginally published in varlous paperback reports of the study committees and are now found in at least one of the services covering the Code: BENDER'S UNIFORM COMMERCIAL CODE SERVICE, REPORTER-DIGEST (Matthew Bender \& Co., Albany, New York).

\section{State Varlations}

Although varlations in the Offlcial Text of the Code that are made by many of the states do not seem to be a ilkely source of Information as to the Code's meaning, they sometimes have value in construing the Code. This is especlally true where the variation is one that has been noted by the Permanent Editorial Board (see below) In its Report Number 2 released in 1965. Thls report not only IIsts the varlations, adopted by the first 30 states enacting the Code, but It also contalns a comment by the Permanent Editorial Board indicating why a variation was rejected and was not incorporated in the Officlal Text.

\section{Permanent Editorial Board}

In order to assure perlodic review of Code provisions and case developments under It. The American Law Institute and the Natlonal Conference have established a Permanent Edltorlal Board for the Uniform Commercial Code, charged with the responsibility of keeplng abreast of Code adoptions, state varlations, and decided cases. This Board has been Issuing annual reports, and has been considering suggested amendments of the Officlal Text of the Code. The Board has also volunteered to submit amlcus briefs on code cases when requested by a court. The work of the Board often is valuable in indicating new developments as well os in alding In construction of code provistons. 


\section{UNIFORMITY}

Out-of-State Cases

An important command of section 1-102 is that the Code be interpreted so as "to make unlform the law among the varlous jurlsdlctions." Perhaps the most important aspect of this mandate is what it tells us about the use that a court (and advocate) should make of out-of-state cases. The hope of the draftsmen, as well as that of the leglslatures that enacted section 1-102, is that widespread enactment of the Code would lead to the development of a body of commerclal law common to the nation, not simply common to one state. This wlll be achieved only if cases correctly decided in one jurisdiction are followed in other jurisdlctions.

Pre-Code Cases

As the Code increases the value of out-of-state cases, It decreases the value of cases declded in a state prlor to the Code. These cases are not interpretative of the Code. If a state follows a particular pre-Code vlew simply because of these prior cases, the sought-for uniformity and the whole polnt of the Code will often be missed.

\section{CONCLUSION}

If the Unlform Commerclal Code is to ald businessmen and make a substantlal contribution to American jurisprudence, lawyers and judges must approach construction of its provisions with the same inventive spirit with which they regard case law. If the Code gives no specific answer to an issue, they must search for a result that is fair between the partles and in keepling with the baslc policies of the Code.

As noted, the sources of policies are diverse: the statute 1 tself, the drafting history, offlclal comments, state varlations, reports of the Permanent Editorial Board, and the writings of those who helped draft its provisions. None, except the statute where it is clear, is controlling. But each contributes to an understanding of the Code, and each should be consulted as an aid to a practical, common-sense, resuit that will be consonant with businessmen's reasonable expectations.

For the past two decades, many have labored to give our legal system a comprehensive and workable statute that wlll "simpllfy, clarlfy, and modernlze the law governing commerclal transactions." Section $1-102(2)(a)$. By its open-ended provisions, the draftsmen and consultants expressed great confldence in the ablility of the bench and bar to expand the Code's provisions by judicial decree. It can only be hoped that thls will be done. 
Page intentionally left blank. 
Consider carefully Section 2-3.13 of the Uniform Commercial Code and the Comments thereto. Does "promise" as used in $\$ 2-313$ have the same connotation as "promise" in the Restatement of Contracts? Is a description of the goods sold that is contained in the contract for sale a "promise" that the goods delivered will conform to that description. What is the difference between "promise" and "affirmation of fact?"

Section 2-313 states that any affirmation of fact or promise can become a warranty. But, the section provides for some flexibility by also providing that (1) "sellers' talk" does not become a warranty (subsection (2)); and (2) a promise or affirmation must form a part of the "basis of the bargain in order to constitute a warranty. See also Section 2-208 2nd Comment 5 to Section 2-313. How do you determine whether a particular collection of words is a warranty under Section 2-313? Is 1 t any easier to make this determination under the statutory language of Section 2-313 than it is under the Restatement or under the cases previously studied? Consider whether the following phrases should be construed as warranties under 2-313 or promises under the Restatement:
a. Winston taste good as a cigarette should
b. These raincoats will sell like hotcakes
c. This product is the same as you ordered, but made by a different manufacturer
d. Regular price: $\$ 159$

The Code also provides for "1mplied" warrantles. See $\$ \$ 2-314$ and 2-315. Are the 1mplied warranties "promises" by the seller that are implicit. in the deal? Are they "implied" in fact, 1.e. somehow arise because of the common understanding of the parties; or are they "implied" in law, $1 . e$. obligations imposed by the law in an attempt to do fustice? Are they "contract" or "tort"? Consider the case of Sylvia Coal Co. Inc. v. Mercury Coal \& Coke Co., that follows. Is not the only issue in this case a question of what the seller promised?"

SYLVIA COAL CO., INC. V. MERCUPY COAL \& COKE CO.

West Virginia Supreme Court of Appeals, July 11, 1967

156 SE2d 1

[Sy1labus by the Court]

1. Where there is a conflict in the evidence with regard to whether an express or implied warranty exists, the question is one for jury determination as to whether or not either or both of such warranties exist in the sale of the goods or product.

2. Under the Uniform Comercial code the buyer can be held to pay a reasonable price where there has been no price fixed for the goods or product sold.

3. "Where, in a suit in assumpsit, the verdict is for plaintiff in an amount less than he is entitled to recover, such verdict will not be set aside and a new trial awarded for that reason alone, on defendant's motion, 
If the plaintiff is willing to accept the verdlct of the jury." Syllabus 1, Blair-Parke Coal and Coke Company v. Fiedler-Davis Fuel Company, 98 W. Va. 374.

4. "The fact that a sample is exhlbited does not necessarily make the transaction a sale by sample. The contract must evince intention to contract by sample." Syllabus I, American Canning Co. v. Flat Top Grocery Co., $68 \mathrm{~W}$. Va. 698.

5. There can be no sale by description under Code, $46-2-314$, as amended, where the buyer selects the goods or product sold.

6. The price to be paid for goods or products sold may be considered by a jury in connection with the quallity intended as to whether an implled warranty of merchantability exists.

7. An implied warranty of fitness for a particular purpose under Code, 46-2-315, as amended, does not come into being unless the buyer relles on the seller's skill or judgment in connection with the matter or goods purchased.

8. An instruction containing the word "may" telling the jury that it may find a verdict for one of the parties is a permissive and not a binding instruction, and it is not error to give such instruction even though it omits certain details relative to the elements of the matter involved if other instructions given by the court instruct the jury fully and fairly with regard to the matter.

BERRY, Judge. This is a civil action instituted in the circuit Court of Preston County by the Sylvia Coal Company, Inc, , hereinafter referred to as Sylvia or plaintiff, against the Mercury Coal \& Coke Company, a Corporation, hereinafter referred to as Mercury or defendant, to recover the sum of $\$ 3,548.37$ for 1419.35 tons of coal dellvered by the plaintiff to the defendant at $\$ 2.50$ per ton. The jury returned a verdict in favor of Sylvia in the amount of $\$ 1,000$ and after the judgment was entered thereon by the trial court a timely motion to set aside the judgment was overruled and final judgment was entered April 5, 1966. Upon application to this Court an appeal and supersedeas were granted November 14, 1966, to the judgment of April 5, 1966. The case was submitted for decision upon arguments and briefs on the April Speclal 1967 Docket of this Court.

The facts in this case are highly confllcting. The plaintiff contends one thing with regard to the contract of the sale of coal and the defendant contends another. Both rely on the Uniform Commercial Code which was enacted into law by the legislature of this State in 1963 and consists of Chapter 46 of the Code of West Virginia at the present time. This is ona of the first cases presented to this Court involving the provisions of the Uniform Commercial Code, and particularly that portion which deals with the three usual types of warranty occurring in sales under the Code, namely, express, merchantabliity, and fitness for a particular purpose.

Sylvia was operating a coal mine in Preston County in August, 1964, under the supervision of Albert Phillips. Mercury was operating a coke production 
plant in Preston County and was owned principally by Wayne H. Fortney. The Mercury Coke operation had been operated by Mr. Fortney for some time and he was experienced in the production of coke from coal largely purchased by him from Preston County producers. The Sylvia mine had just been recently opened and $\mathrm{Mr}$. Fortney, who had known Mr. Phillips for about 15 years, visited the Sylvla operatlon about August 16, 1964, at which time he stated he called on Mr. Phlllips to discuss obtaining the services of Mr. Phillips to reopen the Morgan coal mine which was partly owned by Mr. Fortney and had been closed by reason of a fire. The first coal taken from the Sylvia mine had been dumped in two large plles near the mouth of the mine. $\mathrm{Mr}$. Phillips admits having some previous dlscussion with Mr. Fortney with regard to the reopening of the Morgan mine and also some discussion after his vislt to the Sylvia operation, but does not recall any detailed discussion with regard to the Morgan mine at the time the controversy over the purchase of the coal in question in this case is involved.

Mr. Phillips stated that when he came out of the mine Mr. Fortney was looking at the coal plles and inquired about a purchase of that coal. Mr. Fortney stated that they first discussed the problem of the Morgan mine and that then one or the other of them discussed the purchase of the coal located in the coal pile near where they were standing. Mr. Phillips testifled that when $\mathrm{Mr}$. Fortney inquired about the coal contained in the coal pile that he told $\mathrm{hlm}$ it was a substandard quality and contained considerable slate and rock. He said that $\mathrm{Mr}$. Fortney told him he was making a cheap grade of coke and would pay $\$ 2.25$ to $\$ 2.50$ a ton for that coal and nothing was said about the ash content. No analys is had been made of the ash content of the coal piles located near the opening of the Sylvia coal mine. However, an analysis had been made of coal taken from another part of the Sylvia mine which showed about 9 or $10 \%$ ash which Mr. Phillips stated that he told Mr. Fortney about and showed him the analysis. It was suggested elther by Mr. Phillips or Mr. Fortney at that time that if the coal located in the coal plles were run through a tipple to clean it, that would improve the quality and $\mathrm{Mr}$. Fortney said he could use it if that was done. There was a tipple about two miles from the Sylvia coal mine and at the direction of Mr. Phillips, in accordance with the agreement with Mr. Fortney, 1546.24 tons of coal from the coal pile at the Sylvia mine were hauled to the tipple nearby and run through the tipple and about 127 tons of rock and slate were plcked out of the tonnage from the plcking table when it was run through the tipple leaving 1419.35 tons of coal which was delivered to the coke yard of Mercury on August 17th and 18th. The cost to Sylvia in the hauling and cleaning of the coal was $\$ 1588.09$.

On August 18th Mr. Fortney came to the Sylvia mine and told Mr. Phillips to stop loading any more coal from the coal mine until an analysis was made of the coal. However, at that time Mr. Fortney, after looking at the same coal pile, again ordered three more truck loads and personally directed the highlift operator how, when and where to obtain the coal from the coal plles.

Several days later Mr. Phillips went to Mercury coke plant where Mr. Fortney advised him that an analysis of the coal showed that It was about 33.8 to $35.6 \%$ ash and showed him a sample of the coal which he had unsuccessfully endeavored to make coke from. Mr. Fortney then told Mr. Phlllips in 
effect that he did not want the coal that had been dellivered and that If Phillips could sell it he would load it free of charge. It was Mr. Phillips' contention that the coal in question was purchased by $\mathrm{Mr}$. Fortney and he was not interested in the further disposition of it. Mr. Phlllips had never been engaged in the producing of coke in his experlence in the mining of coal and had never been engaged in the sale of coal for any purpose and although he knew very little about the making of coke, he stated that he would not consider coal with $35 \%$ ash content suitable for making coke. Witnesses who were engaged in the purchase and sale of coal and who testifled in behalf of Mercury stated that it was the custom of the coal business for unacceptable coal to be rejected at the point of destination because the buyer as a general rule does not see the coal untll it is dellvered and has no opportunlty to ascertain if it was what he ordered untll it was delivered. The defendant also introduced evidence that coal with over $30 \%$ ash was not sultable for coking purposes and that good quallity coal for coking purposes sells for around $\$ 4.50$ to $\$ 7.00$ a ton and that the most sultable coal is around 8 to $10 \%$ ash for coke. It was also indicated that the prior inspection of the coal before it was delivered would have some bearling on the right to reject the coal.

Mr. Fortney's testimony was in conflict with that of Mr. Phlllips in many instances. He testlifled that he used coal with up to $16 \%$ ash to produce coke for whlch he paid $\$ 2.25$ to $\$ 3.00$ a ton and that he had paid up to $\$ 7.00$ a ton for coal with $8 \%$ ash to produce good coke. He testlfled that he told $\mathrm{Mr}$. Phillips that he would pay $\$ 2.25$ for $16 \%$ ash content, $\$ 2.50$ for $14 \%$ ash content and $\$ 2.75$ for $12 \%$ ash content and that he asked what the analysis of the coal being opened up was, that Philllps showed hlm a bag and said it was a sample, and that it was around $9-1 / 2 \%$ ash. Fortney interpreted this as applying to the plles, as that was the only coal out of the mlnes. He also said he told Phillips that he would not buy coal that was over I6\% ash and that Phillips stated that he would deliver coal not over $16 \%$ ash content for $\$ 2.50$ a ton.

There is very little conflict in their statements with regard to the cleaning and dellivering of the coal. Fortney sald he visited the tipple on August 18th where the coal was belng cleaned and that he was not satisfied with the way the rock and slate were belng plcked from the coal and asked that the tipple be slowed down so that they could get more of the rock and slate out but was advised that it had been slowed down as much as possible. He asserted that after he vislted the tipple where the coal was being cleaned he asked Phillips not to send any more untll he got an analysis back. He stated that Phillips suggested that there were three or four more trucks to load and he told hlm to go ahead and load and delliver them and admitted that he personally directed the highlift man where to place the shovel in the coal to load the trucks. He sald that he agreed to take the additional truck loads of coal in order to keep the truck drivers from losing work.

At the conclusion of the plaintiff's evidence and at the conclusion of all the evidence the defendant moved for a directed verdict on the ground that the evidence clearly showed that there was an express warranty and an implied warranty of merchantabllity and of fitness for the particular use for which the coal was sold and that there was no evidence that the breach of these warranties had been waived. These motions were overruled. After the entry of judgment on the verdict a motion was again made under Rule 50, RCP for a judgment in favor of the defendant or in the alternative under Rule 59, RCP for a new trlal, all of which were overruled. 
Several errors are relled on for reversal, which in their essentials are: (1) The plaintlff did not prove any agreed price for the coal, (2) there was no evidence to support the verdict of the jury in the amount of $\$ 1,000$, (3) the uncontradicted evidence established the existence of $1 \mathrm{mpll}$ led warranties of merchantablility and of fitness for a partlcular purpose and an express warranty, breaches of which were not walved, (4) that the motlons for a directed verdict and to set aside the verdict and judgment and enter a judgment for the defendant or grant a new trial should have been sustained, (5) that instruction 2 of the plaintiff which was given by the court was improper, and (6) that the evidence with regard to the cost of cleaning and dellvering the coal was improper.

The contention of the defendant that the evidence establishing express and impiled warranties is uncontradicted is without merlt, as the record clearly shows that these matters were virorously in dispute. The evidence of the plaintiff indicates that there was neither an express nor implled warranty while the evidence of the defendant indicates that there were both an express and one or more implied warranties. At the pre-trial conference an agreed statement of facts by the parties contained in an order entered by the trial court on November 15, 1965, clearly shows that the evidence was in direct conflict that the evidence of plaintiff would be that the coal was purchased without any warranty, express or implled, and that the defendant would contend that there was an express warranty with regard to the ash content and an implled warranty with regard to the merchantabllity of the coal. The express warranty relled on by the defendant is that the plaintiff warranted the coal to be less than $16 \%$ ash. The plaintiff specifically denles that any such warranty was made and asserts that the coal was bought by the defendant after an inspection of the coal and that the defendant's buyer saw and knew what he was getting, and not only that, but in addition after more than 1400 tons had been delivered he ordered more of the same coal. Also, the plaintiff contends he agreed to take the coal after it was cleaned and the rock and slate picked from It.

It has aiways been true, both before the adoption of the Uniform Commerclal Code and after its adoption, that where there is a conflict in the evidence with regard to whether an express or implied warranty exists the question is one for the jury to determine as to whether or not such warranty exists in the sale of the goods or product. 46 Am. Jur., $\$ 348 ; 67$ ALR2d 619,626; Kemble v. Wiltison, $92 \mathrm{~W}$ Va 32, 38, 114 SE 369; Kirk v. Stineway Drug Store Co., 38 III App 2d 415, 187 NE2d 307; De Graff v. Myers Food, inc., Bucks County (Penn) 19 D \& C2d 19, [1 UCC Rep 110] 2 Bender's Uniform Commercial Code Service, Reporter Dlgest 2-185, Sec. 2-315. See Officlal Comment 1 , Michie's West Virginia Code 46-2-315; Officlal Comment 5, Michle's West Virginia Code $46-2-316$.

The contention of defendant that the plaintiff did not prove the price for which the coal was to be sold is also without merit. The evidence of the plaintlff indicated that the prlce would be about $\$ 2.50$ and that is what he contended should be pald for the sale of the coal, and even if there had been no price fixed under the Uniform Commerclal Code the buyer can be held to pay a reasonable price. Code, 46-2-305, as amended; Kuss Machl ne Tool \& Die Co. v. El-Tronics, Inc., $393 \mathrm{~Pa} 353,143$ A2d 38. 
The contention that the coal in question in the stock plle or coal plie was sold by sample of some coal that the plaintiff had analyzed is disputed by the evidence of the plalntiff because Mr. Phillips stated that the sample was taken from good coal mined from the mine and analyzed as 9 or $10 \%$ ash content, and he asserts that he clearly stated to Mr. Fortney that the coal In the stock plle was substandard coal and that the sample and statements made as to it were not in any way made a part of the basis of the contract to purchase the coal as an express warranty under Code, 46-2-313, I (a) and (c), as amended. In any event this question, as well as the question of the express warranty that the coal in the stock pile was less than $16 \%$ ash is a question for jury determination. See Officlal Comment 3, Michie's West Virginia Code 46-2-313. This matter is clearly covered in the first syllabus of the case of American Canning Co. V. Flat Top Grocery Co., $68 \mathrm{~W}$ Va 698, 70 SE 756, in the following language: "The fact that a sample is exhlbited does not necessarily make the transaction a sale by sample. The contract must evince intention to contract by sample."

There is no question in this case but that the defendant inspected the coal In question before it was cleaned and dellivered which could exclude an express warranty if he relied upon $h$ is examination rather than affirmations, descriptions and samples, and which could exclude implled warrantles covering patent defects which his buyer's sklll ought to have disclosed to him, and the question of what effect his examination had is, with conflicting evidence or evidence which may be interpreted more than one way, a jury question. Likewise, there can be no sale by description under Code, 46-2-3i4, as amended, where the buyer selected the coal as was done In the case at bar. 3 Bender's Uniform Commercial Code, \$ 7.01[3][a]; Torpey v. Red OwI Stores, 228 F2d 117.

Another matter for jury consideration with regard to the existence of an implied warranty in connectlon with the quality intended is the price to be paid for the coal in question. The evidence of both the plaintiff and the defendant is uncontradicted that the price was from $\$ 2.25$ to $\$ 2.50$ a ton, which is lower than the standard price for coal to be used for coklng purposes. The price of such coal from the evldence is around $\$ 5.00$. Therefore, the jury could consider this matter in connection with the obligation under the contract for the sale and purchase of the coal. See official comment 7 , Michie's West Virginia Code 46-2-314, whlch polnts out that the nature and scope of an implied warranty of merchantability, which is a concept relating to overall quality rather than fitness for a partlcular purpose, are excellently outlined by consideration of the selling prlce.

The implied warranty of fitness for a particular purpose under Code 46-2-315, as amended, does not come into being unless the buyer relies on the seller's skill or judgment in connection with the matter or goods purchased. The evidence in this case clearly shows that Mr. Phillips had no experience in the sale of coal to make coke or for any other purpose and his experience was only in the production of coal and that Mr. Fortney was experienced and skilled in the purchase of coal, especially for his coke company, and he in no way relled on the judgment of the seller in the selection of the coal involved in the case at bar. Furthermore, Mr. Phlllips, the seller, was not a merchant for the sale of coal and in such case the Implied warranty of fitness for a particular purpose is not ordinarily applicable. See Official Comment 4, Michie's West Virginia Code 46-2-315. 
The evidence of the plaintiff, if believed, indicates that there was no implied warranty of merchantability in connection with the contract for the sale of the coal. Mr. Phillips asserts that he told Mr. Fortney that the coal which was sold to him was substandard quality, and Mr. Fortney examined the coal and agreed to have it cleaned of rock and slate and dellvered without analysis. Later he stated that he wanted the delivery stopped until an analysis could be made but immediately agreed to the purchase and delivery of more of the coal which contained the same ash content. Under these clrcumstances this would tend to prove the exclusion of implled warranties as allowed by Code, 46-2-3163(a) and (b), as amended.

All of the evidence detalled herein makes this case one for jury determination as to whether or not the coal in question was sold with or without express or implied warranty. The jury having found for the plaintiff that under the evidence there was no express or implled warranty and having been properly instructed, we find no reversible error in the disposition of this case by the trial court.

It is contended by the defendant that instruction number 2 of the plaintiff, which was the only instruction given in behalf of the plaintiff and which was amended by the court, is reversible error. It is contended that it is a binding instruction, but this is not correct. It states instead that the jury may find for the plaintiff, which makes it a permissive instruction and allows the jury to find under the evidence whether there were express or implied warranties that would prohibit the plaintiff from recovery if breached. Walker v. Robinson, $141 \mathrm{~W}$ Va 563, 91 SE2d 468; Davis v. Fire Creek Fuel Co., $144 \mathrm{~W}$ Va 537, 109 SE2d 144. Although this instruction did not define in detall the elements of express and implled warrantles, the instructions of defendant that were given did instruct the jury with regard to the detalls of implied and express warranties and what each consisted of and fully suppiemented instruction number 2 of the plaintiff in connection with this matter. Hesson v. Penn Furniture Co., $70 \mathrm{~W}$ Va 141, 73 SE 302; Lawrence v. Nelson, $145 \mathrm{~W} \mathrm{Va}$ 134, 147, 113 SE2d 241. We find no error in the instructions given to the jury and its disposition of the case.

For the reasons stated herein the judgment of the circult Court of Preston County is affirmed.

Affirmed.

The Sylvia Coal Co. case involves a commercial dispute: a controversy between two businessmen over a business deal. Consider the following case. Does it have a different flavor? Are the Code sections on warranties serving a somewhat different function? 
ANDREA MARIE MCCORMACK, by Donald

MCCormack, her father and natural

guardlan, Appellant,

$\checkmark$.

HANKSCRAFT COMPANY, Inc., Respondent.

No. 39627

Supreme Court of Minnesota.

Nov. 17, 1967

Rehearing Denled Dec. 12, 1967. 278 MInn. 322, 154 N.W.2d 488 (1967)

\section{Syllabus by the Court}

1. A manufacturer is subject to llabllity for fallure to exercise reasonable care in designing its product to protect users or those endangered by its probable use from unreasonable rlsk of physical harm whlle its product is being used for its intended purpose. Liablility also may be predicated upon fallure to exercise reasonable care in the adequacy of its instructions as to the use of its product and a warning as to any dangers reasonably foreseeable in its intended use.

2. Where the evidence permitted the jury to find that plaintiff, a 3-yearold child, sustalned third-degree burns by contact with the undisclosed presence and rapld discharge of near-bolling water from an electric steam vaporizer manufacturered by defendant which plaintiff upset whlle it was being used in the manner prescribed and for the purpose intended by defendant, and that defendant, who knew or should have reasonably foreseen that a child might be severely burned by scalding water upon upset, falled to warn of such danger, which it should have reallzed was neither obvious nor likely to be apprehended by users, or failed to protect against the danger by exerclsing due care in adopting a safe, alternative design to make the vaporizer safe for use unattended in a child's room, the evidence justified the verdict finding that defendant's negligent lack of warning and defective design caused plaintiff's injuries.

3. In an action for personal injuries caused by a defective product, a manufacturer also may be subject to liability for breach of an express warranty despite the nonexistence of privity between the manufacturer and the injured person and the failure to give notice of the breach. Held, the evidence justifled the verdict finding defendant liable to plalntiff for breach of an express warranty.

4. Abolishing the requilements of privity and notice in personal injury actions sounding in breach of warranty is only a transparent device to el iminate bars to recovery imposed by the law of sales. Preferably, a manufacturer 
of a defective product should be held llable to a user or those endangered by its probable use under the now tested and developing rule of strict tort liability, imposed by $1 \mathrm{aw}$, as a matter of policy, without the limitations of any lilusory contract defenses.

5. Where, pursuant to a blended motion for judgment notwithstanding the verdict or a new trial, a conditional order granting a new trial is based in whole or in part upon the insufficlency of the evidence and such issue is also raised and determined on review of the order granting judgment notwithstanding the verdict, the order granting a new trial is subject to discretionary review by this court.

Robins, Davis \& Lyons, and John F. Eisberg, St. Paul, for appellant.

Murnane, Murnane, Battis \& Delambert, St. Paul, for respondent.

OPINION

ROGOSHESKE, Justice,

Plaintlff appeals from the Judgement entered upon an order of the district couxt granting judgment n.o.v. and a conditional new trial in favor of defendant, Hankscraft Company, Inc.

Plaintiff, Andrea McCormack, brought this action for damages by Donald McCormack, her father and natural guardian, alleging that defendant's negligence and breach of implied and express warranties in the manufacture and sale of a steam vaporizer caused her to suffer substantial personal injuries. During the 3-week trial, defendant's motions for a directed verdict following the submission of plaintiff's evidence and at the close of all the evidence were denied. The court submitted the case to the jury on the questions of negligence and breach of express warrantles, refusing to instruct on inplied warranties. The jury returned a verdict againgt defendant, awarding plaintiff $\$ 150,000$ damages.

Defendant's motion for judgment n.o.v. and in the alternative for a new trial was granted. The motion alleged multiple grounds, including that the verdict was "not justified by the evidence," was "contrary to law," and that there were "excessive damages," but the court in its order merely declared that the motion "Is in all things granted" without expressly specifying the grounds upon which the rellef was granted.

Understandably, the brlefs comprehensively attack or seek to justify the court's order; but, as the parties apparently agree and as we view it, the primary issue is whether the evidence is sufficient to sustain the jury's verdict of liabllity upon a theory elther of negligence or breach of express warranty.

Viewing, as we must, the evidence and all permissible inferences most favorably to the sustaining of the verdict, the fury reasonably could have found the following facts.

In October 1957, Andrea's father, Donald McCormack, purchased from a retail drugstore an electric Hankscraft steam vaporizer manufactured by defendant. It was purchased pursuant to the advice of a doctor to be used as a humidifier 
for Andrea, then 8 months old, who had just returned from being hospltalized for croup and pneumonia. After unpacking the vaporizer, Andrea's parents read the Instruction booklet accompanying the unit from "cover to cover." Then, following defendant's printed instructions, they put the vaporizer to use in the treatment of Andrea. Thereafter, from time to time as the need arose, it was used for the young children of the family in the prescribed manner, Including the use of it unattended throughout the night, without any problem.

The vaporizer was used exclusively in the treatment of the children of the family. After its initial use, Andrea's mother invariably took charge of filling 1t, setting it up, plugging in the electric cord, replentshing the water In the glass jar, and occasionally, as directed by the booklet, cleaning the heating unit. In using the vaporizer, she relled upon defendant s printed representations that the unit, except for cleaning, needed no attention, could be left unattended in a child's room, would "run all night on one f1lling of water," and was "safe" and "Practically foolproof."

In the spring of 1960 , the children had colds and Mrs. McCormack destred to use the vaporizer but found it "wasn't working." She went to the same self-service drugstore and purchased another Hankscraft vaporizer simllar to the first unit. She personally selected $1 t$ without the aid or recommendation of any clerk because it was a Hankscraft, knowing defendant to be a manufacturer of a number of products for children and relying upon defendant's prior representations contained in the booklet accompanying the first vaporizer that Its vaporizers were "safe" and "practically foolproof" as well as advertisements representing them to be "t1p-proof." This second vaporizer, purchased in a sealed carton, was known as Model 202A, and 1 ts general appearance as to size and shape and its method of operation were identical with the first untt. It was accompanied by an instruction booklet substantially identical to that furnished with the first vaporizer, which Mrs. McCormack again completely read.

This second vaporizer had been used about a half dozen times without Inc1dent when, on November 20,1960 , it was again set up for use in a small bedroom in the northwest corner of the house, occupled by Andrea, then 3 years and nine months old, and her baby sister, Alison, 1 year and 10 months old. Andrea slept in a regular single bed and Alison in a crib. To the east of the doorway of this bedroom is an adjoining bathroom, which Andrea frequently used during the night. The doors of the bedrooms and bathroon were habitualiy left open and a light was usually burning in the bathroom. Andrea's bed was located in what might be described as the southwest corner of the room with the headboard against the doorway wall. The crib was in the northeast corner. A chifforobe stood next to the crib agalnst the north wall. Andrea's mother set up the vaporizer at about $8 \mathrm{p} . \mathrm{m}$. on a seat-step-type metal kitchen stool about 2-1/2 feet high. She placed the stool in front of and against the chifforobe. The electric cord was extended behind the chifforobe and plugged into an outlet located there. The stool was about 4 feet from the foot of Andrea's bed. When steam started coming from the hole in the top of the unit, Mrs. McCormack left the room. After visiting a neighbor unt 11 about 11 p.m.s she did some ironing, and at about $1: 30 \mathrm{a} . \mathrm{m}$. , she returned to the room to replenish the water supply in the vaporizer. Using some type of "mitt, "she lifted the cap and poured water from a milk bottle into the jar. She then went to bed. 
At about 2:30 a.m., Mrs. McCormack heard a terrible scream and got out of bed. She found Andrea lying on the floor of her bedroom, screaming. The metal stool was upright, but the vaporfzer was on the floor and the water had come out of the far. The vaporizer had separated into its three component parts--a glass jar, a metal pan, and a plastic top-heating untt. The electric cord was still plugged into the electric outlet. In some manner, Andrea, while intending to go to the bathroom, had tipped over the vaporizer, and caused the water in the jar to sp111 upon her body.

Andrea was rushed to the hospital for treatment. More than 30 percent of her body had severe burns; she was suffering from shock; and her condition was critical for some time. She had third-degree burns on her chest, shoulders, and back. Skin-graft surgery was performed on her twice. She was hospltalized for 74-1/2 days. Ten days later she was admitted to the Kenny Institute for treatment. She remained there 102 days and thereafter was taken to the Mayo Clinic, where she had further surgery in August 1961. At the time of the trial, Andrea had heavy scar tissue on her chest, stomach, legs, arms and neck; a deformed $j$ aw; restricted movement of her head: an irregular posture: and the prospect of 6 to 12 more surgical procedures during her lifetime. Her condition is largely permanent.

The "automatic-electric" vaporizer in question is of normal design and consists of three component parts--an aluminum pan which serves as a base, a 1-gallon glass $j$ ar or water reservoir which is inserted into the pan, and a black plastic cap to which is fastened a black plastic heating-chamber tube.

The glass $\mathrm{jar}, 6-5 / 3$ inches square and 8 inches high, is a so-called "standard gallon pickle jar" not specially manufactured as a component part. The top opening is 4-1/2 inches in diameter and 1ts outer neck has a male-type glass thread. To $f 111$ the jar to a designated f1ll mark requires .73 gallon of water.

The aluminum pan, which is made to fit the bottom of the far, is 4 inches high. It has two plastic lifting and carrying handles. Four projections, $3 / 4$ inch in diameter and $1 / 8$ inch in helght, are regularly spaced on the bottom of the pan and serve as feet for the unit.

The plastic cap and heating chamber assembly has a dome-11ke appearance in its upper portion, which is 5 inches in diameter and 2-3/4 inches h1gh. Enclosed in a plastic tube which attaches to the upper portion are two narrow, 8-inch-1ong steel electrodes which extend from the underside of the cap and are fastened to terminals which connect to an electric plug-in type cord. This cord, about 6 feet long, is attached to the terminals through a hole in the cap. Opposite the electric cord is a round steam hole $3 / 16$ inch in diameter. Directly below this there is moulded into the top a "medicament hollow." The heating chamber tube enclosing the electrodes is about 7-5/8 inches long. It. consists of a lower section 5-1/8 Inches 1ong, which tapers upward from 1-1/2 - inches to 1-7/8 inches in diameter, and an upper section 2-1/2 inches long and 3 inches in diameter. The upper section has a flange 3-3/4 inches in dlameter through which three screws are used to fasten both sections to the cap. A hole $1 / 8$ inch in diameter is in the bottom of the lower section through which water in the jar reaches the electrodes. Eight holes $1 / 4$ inch in 
diameter are in the bottom of the upper section. They are intended to relleve any steam pressure that might build up inside the lower tube or the jar should the steam hole become obstructed and also to guard against "any chance of water spitting out the steam hole." The cap and heating chamber assembly, by Its own welght, rests loosely upon the glass jar with the black tube extending down into the far. There are no threads inside the plastic cap or any other means provided to fasten the cap to the threaded neck of the far. This design and construction were intended by defendant to serve as a safety measure to avold any bulldup of steam in the glass $j a r$, but it also has the result of allowing the water in the far to gush out instantaneously when the vaporizer is tipped over. This unit can be tipped over easily by a child through the exertion of about 2 pounds of force.

To operate the vaporizer in accordance with the instrutions contained In defendant's booklet, the "entire plastic cover" 1s removed, the glass jar is filled to the filling marker with tap water containing minerals, and the cord is plugged into an electric outlet, whereupon "[ $t$ ] he vaporizer will produce a gentle cloud of steam within a few minutes." The heating unit is designed so that it automatically turns off whenever the water in the jar decreases to a certain level. As the booklet pictorlally 1llustrates, the water from the jar enters the lower section of the heating chamber through the small hole at the bottom. Here it is heated until it bolls and is vaporized into steam, which passes out of the unit through the hole in the cap.

Tests made of the unit established that after about 4 minutes of operation the water in the heating chamber reaches 212 degrees Fahrenheit and steam emanates from the steam port. Although the water in the $\mathrm{j}$ ar outside the heating chamber does not reach the boiling point, the upper portion of this water does reach 211 degrees within 35 minutes of operation and the middle portion reaches 211 degrees within 3 hours. The temperature of the outslde of the far ranges from 172 degrees after about 1 hour to 182 degrees after 5 hours. Thus, during most of the 6- to 8-hour period in which the unit is designed to operate without refilling, the water in the reservolr is scalding hot, since water of 145-degree temperature w111 burn and 180-degree water will cause third-degree burns on a child 5 years old.

By touch, a user can determine that the water in the jar outside the heating unit, as well as the $\mathrm{jar}$ and the plastic cap, becomes hot during the operation of the vaporizer. However, there is no movement of the water In the jar and no means by which a user could discern by sight or touch that this reserve water in the jar became and remained scalding hot. Plaintiff 's parents, relying upon their understanding of what defendant represented in its instruction booklet, were reasonably led to belleve up to the time of plaintiff's injury that, since steam was generated only in the heating unit, the temperature of the water in the far during the entire operation of the vaporizer remained the same as when put in. At all of the times when replenishing the water in either the first or second vaporizer, plaintiff's mother followed the routine of removing the entire plastic cover by using some "glove" or "mitt" as a precaution against the steam. She would leave the cord plugged in, add water to the jar, replace the cover, wait until steam appeared, and then leave the unit unattended in the room. As her testimony Implied, she at no time discovered by touching or handling the 
unit when 1 t was in use that the temperature of any part of the water in the jar became hot.

The Instruction booklet furnished by defendant did not disclose the scalding temperatures reached by the water in the Jar, nor was any warning given as to the dangers that could result from an accidental upset of the unit. While plaintiff's mother realized that the unit could be tipped over by a sufficlent external force, she fustifiably relled upon defendant's representations that it was "safe," "Practically foolproof," and "tip-proof." She understood this to mean that the unit "was safe to use around [her] chlldren" and that she "dIdn't have to worry" about d gers when it was left unattended in a child's room since this was the primary purpose for which it was sold.

In 1 ts booklet and advertising, defendant in fact made the representations relled upon by plaintiff's mother. In addition to the simple operating Instructions and a plctorial "cut-away" indicating how the steam is generated by the electrodes in the heating chamber, the booklet stated:

\title{
"WHY THE HANKSCRAFT VAPORIZER IS SUPERIOR TO OTHERS IN DESIGN.
}

\begin{abstract}
"Your vaporizer w11l run all night on one fllling of water, directing a steady, gentle flow of medicated steam exactly where it is needed. No attention is necessary.

"It's safe, too, and practically foolproof. Since the water itself makes the electric contact, the vaporizer shuts off automatically when the water is gone. The electric unit cannot burn out."
\end{abstract}

The booklet also had a plcture of a vaportzer sending steam over a baby's crib, alongside which was printed:

"For most effective use, the vaporizer should be placed at least four feet away from the person recelving treatment, and should not be placed above the patient's level."

Defendant's officers realized that the vaportzers would be primarlly used in the treatment of children and usually would be unattended. They had knowledge that the water in the jar got scalding hot; that this water would cause third-degree burns on a small ch1ld; that the water in the far would gush out instantaneously if the unit were tipped over: that the unit was not "tip-proof": that the combination of the unsecured top and the hot water in the jar was dangerous because of the possibility that a child might tip it cver during operation: and that, prior to plaintiff's infury, at least 10 to 12 children had been burned in this manner. Furthermore, defendant's officers realized that the fact the water in the far got hot was not discernible during operation except by touching or handling the untt and that a user could conclude from thelr booklet that steam was generated in the plastic core and be led to believe that the reserve water in the jar did not itself become scalding hot. 
Plaintiff called two expert witnesses, whose qualifications in the field of product design were unquestioned. Both testified that the design of the vaporizer was defective princlpally in that it falled to provide a means for securing the plastic cover to the far in a manner which would prevent the water in the far from instantaneously discharging when the unit was tipped over. In the opinion of both, the unit could be tipped over with 1ittle force and this defective design created a risk of bodily harm to a child if the unit were left operating and unattended in the room. This defect could have been eradicated by the adoption of any one of several practical and Inexpensive alternative designs which utilized simple and well known techniques to secure the top to the far. Any of these alternative designs could have been employed by defendant prior to its production of the second vaporizer by the application of sound product-design principles current at that t1me. Among these alternative designs was that of making threads on the Inside of the plastic top so 1t could screw onto the far and the putting of two or three small holes in the top, which would take care of any danger that steam would bulld up inside the far. Both witnesses stated that such a change In design was essential to make the unit safe for its intended use because the presence of near-bolling water in the far was not discernible by sight or touch and no warning of the risk of harm was contalned in defendant ${ }^{8} \mathrm{~s}$ instruction booklet.

Plaintiff contends that the evidence not only raised jury issues as to negligence, breach of warranties, and causation but also is more than sufficient to support the fury's finding of 11ability on the two theories submitted. Defendant contends the evidence presented was so deficient to establish its liability on any ground that it is entitled to a judgment on the merits as a matter of law.

At this late date in the development of the law relating to the tort liability of manufacturers of all types of products for injuries caused by their products, there can be no doubt that a manufacturer is subject to liability for a fallure to use reasonable care in the design of 1ts product to any user or consumer, Including any person who may reasonably be expected to be in the vicinity of 1 ts use, to protect against unreasonable risk of physical harm while the product is used for its intended purpose. Such liabllity may equally be predicated upon a fallure to use reasonable care in giving adequate and accurate instructions as to the use of the product and a warning as to any dangers reasonably foreseeable in its intended use. Lovejoy v. Minneapolis-Moline Power Imp. Co., 248 M1nn. 319, 79 N.W.2d 688.

Plaintiff urges that defendant was negligent both in its fallure to give any warning of the dangers inherent in the use of the vaporizer and in its adoption of an unsafe design. Plaintiff claims among other things that defendant, in undertaking to instruct as to the use of its vaporizer, violated its duty to use due care when 1 t falled to inform that the water in the far got scalding hot with temperatures up to 211 degrees Fahrenhelt and to warn of the dangers of serious injury if the unit were upset during operation. Defendant concedes it gave no such warning but vigorously argues that a warning was not necessary since the fact that the water in the jar becomes and remains hot should be obvious to any user.

In support of 1 ts position, defendant claims that anyone touching the far or plastic top after the vaporizer had been working for some time would 
realize they are hot and conclude the water in the far is also hot, and that because the Instructions indicate that steam is produced in the plastic heating chamber, a reader would necessarily conclude the water in the $j a r$ is hot since the heating unit obviously comes into direct contact with such water. Plaintiff, on the other hand, contends that a warning is necessary because the average user would not realize that this water becomes hot, much less that it becomes scalding hot. Plaintiff relies upon the undisputed evidence that there is no bolling activity of the reserve water in the jar and that there is no way short of actual temperature measurements to discern by sight or touch that this water reaches the dangerous temperature of 211 degrees. Further, plaintiff relies upon the evidence that the instructions furnished by defendant served to allay any suspicions a user might otherwise have as to the near-bolling temperature of the water or any apprehension of danger by indicating that the vaporizer was safe to use unattended in a child's room throughout the night. Moreover, both of plaintiff's parents testifled that neither had in fact become aware of the temperature of the water nor realized the danger that, if the unit were upset while in use, the water could scald and inflict third-degree burns on a child.

We have very little difficulty in reaching the conclusion that the evidence justified the fury in finding that defendant failed to exercise reasonable care to inform users, Including plaintiff's parents, of the scaldIng temperatures of the water and to warn of the dangers reasonably foreseeable in the use of the vaporizer. Hartmon v. National Heater Co., 240 Minn. $264,60 \mathrm{~N}$.T. $2 \mathrm{~d} 804$. Surely the evidence does not as a matter of law compel a conclusion that the true nature and gravity of the dangers which could result from the scalding water in the far were sufficiently obvious to most potential users as to preclude the jury from finding that due care required an appropriate warning. Under the court's instruction, the fury could, and quite likely did, conclude that defendant knew or should have reasonably foreseen that the primary use of its vaporizer involved the danger that a child might be severely burned by the rapld discharge of near-boiling water upon an intentional or accidental upset, and that a substantial number of users would not become aware of the scalding temperature of the water nor realize the potential dangers of using the vaporizer unattended in a child's room unless adequate information and an appropriate warning were given so that parents would take extraordinary precautions. These findings, together with defendant's utter failure to warn, and the finding that the dangers inherent in the vaporizer's use were not obvious and were outside the realm of common knowledge of potentlal users (espectally in view of defendant's representations of safety) 1 are, we hold, supported by the evidence and alone justified the jury's verdict of liability.

We similarly conclude and hold that the evidence is also suffictent to support the jury's verdict of liability on the ground that defendant was negligent in adopting an unsafe design. It is well established that a manufacturer, desplte lack of privity of contract, has a duty to use reasonable care in designing its product so that those it should expect will use it are protected from unreasonable risk of harm whtle the product is being used for

1. Restatement, Torts (2d) \$388, comment $\underline{b}$. 
Its intended use. A breach of such duty renders the manufacturer 1fable. Rosin v. International Harvester Co., 262 Minn. 445, 1.15 N.W.2d $50 .{ }^{2}$ Clearly, such a duty was owed to plaintiff for defendant admitted that the primary, intended use of the vaporizer was for the treatment of children's colds and croup.

The proof is sufficient to support plaintiff's claim of defective design in that, among other defects, ${ }^{3}$ defendant failed to exercise reasonable care in securing the plastic cover to the jar to guard against the reasonably foreseeable danger that a child would tip the unit over when it was in use and be seriously burned by coming in contact with the scalding water that would instantaneously gush out of the jar.

This proof of a specific defect which, under the circumstances, the jury could find caused the plaintiff's injuries distinguishes this case from the factual situations present in Jessen v. Schuneman's, Inc., 246 Minn. 13, 73 N.W.2d 786, and Wallace v. Knapp-Monarch Corp. (8 Cir.) 234 F.2d 853, relied upon by defendant.

To urge that a vaporizer is not a dangerous instrumentality is not persuasive to a reviewing court when the evidence reasonably permits a finding that a simple, practical, inexpensive, alternative design which fastened the top to the jar would have substantially reduced or eliminated the dangers

2. See, also, Johnson v. West Fargo lifg. Co., 255 : Hnn. 19, 95 N.W.2d 497: Lovejoy v. Minneapolis-Moline Power Imp. Co., 248 Minn. 319, 79 N.W.2d 688; Hartmon v. National Heater Co., 240 Minn. 264, 60 N.W.2d 804; Restatement, Torts (2d) $\$ 398$.

3. Plaintiff claimed there were two other defects in design, but we believe the evidence insufficient to predicate liability upon either. It was argued that the water in the far was rendered too hot because the design permitted steam and 1 ts condensate to escape from the elght $1 / 4-1$ inch holes in the upper section of the heating chamber into the water reservoir. But, plaintiff's experts failed to testify that if suggested changes had been adopted the water's temperature would have been reduced sufficiently so that it would not have caused third-degree burns to plaintiff. Plaintiff also argued that the vaporizer could be tipped too easily. While it was established that an alternative design would substantially increase the amount of force necessary to tip it over, the experts falled to testify as to how much force plaintiff likely would have exerted when she tipped the vaporizer over and therefore there was no indication whether the suggested changes would have prevented her from doing so. The matters which were omitted are not subjects of common knowledge, and in the absence of expert testimony, the jury could only speculate as to whether these suggested changes in design could have prevented plaintiff's injury. This constituted a fallure of proof as to proximate cause. See, e.g. Miller v. Raaen, $273 \mathrm{Minn} .109,139$ N.W.2d 877; Ericksen v. Hilson, $266 \mathrm{Minn}$. 401, 123 N.W.2d 687. 
which caused platntiff's injuries. ${ }^{4}$ Defendant's experts testifled that the design adopted was to guard against an explosion because of a buildup of steam in the heating unit and $j a r$, but the fury could have accepted the testimony of plaintiff's experts which indicated the use of defendant's deolgn was not necessary to accomplish this purpose. Moreover, the fact that at the time the second vaporizer was purchased many other brands of vaporizers on the market were designed in basically this same manner, while certainly relevant, did not necessarily bar the fury from concluding that the exercise of due care required the adoption of a different design. 5

We also find no merit in defendant's contention that it was not negligent because any defect caused by its fallure to secure the heating unit to the jar was obvious. Clearly the jury could have justiflably found that users, particularly children such as plaintiff who was a mere child of 3 years of age, are Incapable of meaningfully comprehending the true nature and gravity of the risk to them that results from a product's design and of effectively acting so as to avold the danger. 6 The jury could have concluded that protection of this class of persons required that defendant in the exercise of due care should have adopted one of the safe alternative designs. While the evidence with respect to this issue required a resolution of the conflicts In the testimony of expert witnesses, the jury was free to adopt the opinions of plaintiff's witnesses and to reach a verdict of 1lability on this ground of negligence also.

We also conclude that the evidence was sufficlent to support a finding of liabllity upon a breach of an express warranty.

We are persuaded that whether the prevlously quoted language of the booklet, particularly in combination with the picture of a vaporizer sending steam over a baby's crib, amounted to an express warranty that it was "safe" for a user to let this vaporizer run all night in a child's room without attention was a jury question. No particular words are required to constitute an express warranty, and the representations made must be interpreted as an ordinary person would understand their meaning, with any doubts resolved in favor of the user. 7 since parents instinctively exercise great care to protect their children from harm, the jury could justiflably conclude that defendant's representations were factual (naturally tending to induce a buyer to purchase) and not mere "puffing" or "sales talk."

4. Evidence of the existence of a feasible alternative design eliminating the unattached top renders the holding in Blissenbach v. Yanko, 90 Ohio App. 557, 107 N.E.2d 409, Inapplicable to this case.

5. See, 65A C.J.S. Negligence $\$ 232$. Cf. Hartmon v. National Heater Co., 240 Minn, 264, 60 N.W.2d 804.

6. See, 2 Harper \& James, Torts, \$28.5. Cf. Schipper v. Levitt \& Sons, Inc., 44 N.J. 70, 207 A.2d 314; Wright v. Massey-Harris, Inc, 68 I11. App. 2d 70, 215 N.E.2d 465 .

7. See, McCormack Harvesting Mach. Co. v. Flelds, 90 Minn. 161, 95 N.W.886.

8. Minn. St. 1961, $\$ 512.12$; Corporation of Presiding Bishop, etc. v. Cavanaugh, 217 Cal.App.2d 492, 32 Cal.Rptr. 144. 
The finding, in compliance with the court's instruction, that "plaintiff's parents justifiably relled" on the representations is also supported by the evidence. Nelther parent became aware of the high temperature of the water in the jar nor apprehended any danger from using the vaportzer in the prescribed manner. Plaintiff's mother specifically testifled that she relled on defendant's representations. The jury properly may have viewed this testimony as inherently probable and true and concluded that plaintiff's mother placed substantial rellance upon defendant's express warranty in purchasing the second vaporizer. 9 That she did not rely solely upon the warranty but also was motivated by her own favorable past experlence with the first vaporizer is not determinative. 10 Nor does the fact that the representations In the booklet which accomparied the first vaporizer were not made simultaneousely, with the purchase of the second prevent the conclusion reached by the jury. 11

As previously indicated, there was adequate support for the finding that defendant breached its varranty, since the facts which the jury could find established that the vaporizer was not "safe" for 1 ts primary intended use.

Defendant argues that plaintiff is barred from recovery for breach of express warranty because of fallure to give notice of such breach within a "reasonable time" as required by Minn.St.1961 $\$ 512.49$, of the sales act. We cannot agree. This argument, not unlike defendant's suggestion that the absence of privity of contract between defendant, and plaintiff should 11kewise bar recovery, does not appeal to our sense of justice, It can be disposed of by adopting the rule of some jurisdictions that in personal injury actions alleging breach of warranty no such notice need be given because, as here, plaintiff is not a "buyer" within the contemplation of the statute. 12 But such disposition, and similarly the elimination of privity, ${ }^{13}$ is only a transparent device to reach a desired result by eliminating bars to recovery imposed by the law of sales. Since the recent and often-cited cases of Henningsen v. Bloomfleld Motors, Inc, 32 N.J. 358, 161 A.2d 69, 75 A.L.R. 2d

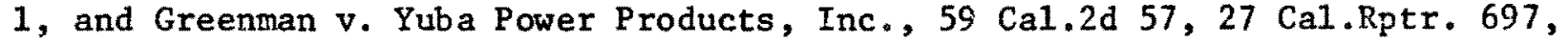
377 P.2d 897, a host of decisions by many courts have adopted the view, first

9. See, Schiling vo Roux Distributing Co., Inc., 240 Minn. 71,59 N.W.2d 907; Hansen v. Firestone Tire Rubber Co. (6 Cir.) 276 F.2d 254; Marko v. Sears, Roebuck \& Co., 24 N.J.Super. 295, 94 A.2d 348; Silverstein v. R. H. Nacy \& Co. 266 App.Div. 5, 40 N.Y.S.2d 916; Rogers v. Toni Home Permanent Co., 167 Ohto St. 244, 147 N.E.2d 612, 75 A.L.R.2d 103.

10. Marsha1l v. Gilman, 52 MInn. 88, 53 N.W. 811.

11. See,Vitro Corp. of America v. Texas Vitrified Supply Co., 71 N.Mex. 95,376 P.2d 41 .

12. See, Lahiue v. Coca-Cola Bottling, Inc., 50 Yash.2d 645, 314 P.2d 421; Piercefield v. Remington Arms Co., $375 \mathrm{MICh} .85,133 \mathrm{~N} . W .2 d$ 129: Wights v. Staff Jennings, Inc., 241 or. 301,405 P.2d 624, which hold, without adopting the rule of strict tort liability discussed in the opinion, that the notice requirement is not applicable to nonpurchasers.

13. This requirement has been expressly abolished by $\$ 2-318$ of the Unfform Commercial Code as to any person "In the family or household of his buyer," enacted after this action arose. Minn.St. 336, 2-318 
urged by Dean Prosser ${ }^{14}$ and now embodied in Restatement. Torts (2) $\$ 402$ $A, 15$ that the liability of a seller to persons infured by 1 ts defective product is not one governed by the law of contract warranties but by the law of strict liability in tort. This rule of strict tort liability, as it is appropriately called, qualifies as a tested legal theory along with the traditional theories of negligence and breach of warranty where the latter meet the purpose for which liablifty should be 1mposed upon a supplier of a product. However, in our view, enlarging a manufacturer's liabllity to those injured by its products more adequately meets public-policy demands to protect consumers from the inevitable risks of bodily harm created by mass production and complex marketing conditions. In a case such as this, subjecting a manufacturer to liabllity without proof of negligence or privity of contract, as the rule intends, imposes the cost of injury resulting from a defective product upon the maker, who can both most effectively reduce or eliminate the hazard to life and health, and absorb and pass on such costs, instead of upon the consumer, who possesses netther the sk111 nor the means necessary to protect himself adequately from elther the risk of injury or Its disastrous consequences.

If traditional commercial contractual limitations, such as the requirement of notice or the doctrine of privity, were applied to this case, defendant's liability upon the ground of breach of an express warranty could not be upheld. Plaintiff would be denied recovery despite adequate proof that the vaporizer was "In a defective condition unreasonably dangerous to the user"; that plaintiff was injured thereby; and that defendant represented the vaporizer as "safe" and did everything by advertising and otherwise to induce that bellef while creating the risk and reaping the profit from its sales. Recovery would be denied unless, as here, the infured plaintiff is able to investigate fully, hire experts, and marshal evidence sufficiently persuasive to convince a jury that evidence of elaborate precautions employed by the manufacturer to make its product safe did not measure up to the standard of reasonable care.

Wthout attempting to discuss the, many cases adopting the rule of strict liability and the many articles testifying to the remarkable shift toward its adoption 16 we hold that neither notice nor privity need be alleged or

14. Prosser, The Assault Upon the Citadel (Strict Liability to the Consumer), 69 Yale L.J. 1099, and Prosser, The Fall of the Cltadel (Strict Liabllity to the Consumer), $50 \mathrm{Minn} . \mathrm{L}$. Rev. 791, where the cases are comprehensively and critically analyzed.

15. Restatement, Torts (2d $\$ 402 \mathrm{~A}$, provides: "(1) One who sells any product in a defective condition unreasonably dangerous to the user or consumer or to his property is subject to liabllity for physical harm thereby caused to the ultimate user or consumer, or to his property, if (a) the seller is engaged in the business of selling such a product, and (b) it is expected to and does reach the user or consumer without substantial change in the condition in which it is sold. "(2) The rule stated in Subsection (1) applies although (a) the seller has exercised all possible care in the preparation and sale of his product, and (b) the user or consumer has not bought the product from or entered into any contractual relation with the seller."

16. Brown v. General Motors Corp. (4 Cir.) 355 F.2d 814 (Ohlo 1aw); Putnam v. Erie City Mfg. Co. (5 C1r.) 338 F.2d 911 (Texas 1aw): Greeno v. Clark Equipment Co. (H.D.Ind.) 237 F.Supp. 427 (Indiana law); Greenman V. Yuba Power Products, Inc., 59 Cal.2d 57, 27 Cal.Rptr. 697, 377 P.2d 897, 13 A.L.R.3d 1049; Garthwatt v. Burglo, 153 Conn. 284, 216 A.2d 189; Suvada v. White Motor Co., 32 I11.2d 612, 210 N.E.2d 182; Dealers Transport 
proved in cases like the one before us. We do so not simply to eliminate these contractual Iimitations upon a claim for personal injury against a manufacturer based upon a breach of an express warranty (as was done long ago with respect to implied warranties) 17 but, more importantly, to declare our agreement with the principles underlying the rule of strict tort 1tabil1ty and to record our intention of applying that rule in this type of case. That this view is consistent with sound public-policy considerations is Indicated by our previous decisions disclosing the active role of this court in the development of the rules respecting a manufacturer's 11ab111ty. Thus, In Schubert v. J.R. Clark Co., 49 MInn. 331, 51 N.W. 1103, 15 L.R.A. 818, we substantially abollshed privity in negligence actions by a consumer against the manufacturer. In Beck v. Spindler, $256 \mathrm{MInn}$. 543, 99 N.W.2d 670, we eliminated this requirement in actions by a purchaser against a manufacturer based upon implied warranties and expressly questioned whether the concept of privity ought not to be completely abrogated in product liability actions resulting in personal infuries.

We are fully mindful that plaintiff did not directly plead the theory of strict tort 1lability, request the court to instruct on it, nor urge this theory unt11 this appeal. however, we perceive no prejudice to defendant, as Its 11ability is adequately established on the ground of negligence. We have discussed a manufacturer's liablitty sounding in warranty to answer defendant's arguments and to disclose forthrightly the basic reasons for eliminating the defenses urged. Moreover, we desire to set at rest such future arguments which seek to ralse various illusory contract defenses to a rule of liablilty which we believe should be imposed by law, In tort, as a matter of pollcy in cases such as this.

We also hold the evidence adequate to support a reasonable inference that defendant's negligence and breach of warranty proximately caused plaintiff's infury. From the fact that plaintiff sustained third-degree burns by coming in contact with near-bolilng water, the obvious and reasonable Inference is that her Infuries were directly caused by the undisclosed

Co. v. Battery Distribut1ng Co. (Ky.App.) 402 S.W.2d 441; Meche v. Farmers Drier \& Storage Co. (La,App.) 193 So.2d 807; State Stove Mifg. Co. v. Hodges, Miss., 189 So.2d 113; Shoshone Coca-Cola Bottling Co. v. Dolinsk1, 82 Nev. 439, 420 P.2d 855; W11llams v. Ford Motor Co. (Mo.App.) 411 S.W.2d 443; Santor v. A. \& M. Karagheusian, Inc., 44 N.J. 52, 207 A.2d 305; Goldberg v. Kollsman Instrument Corp., 12 N.Y.2d 432, 240 N.Y.S.2d 592, 191 N.E.2d 81; Lonzr1ck v. Repub11c Steel Corp., 1 Oh10 App.2d 374, 205 N.E.2d 92: Webb v. Zern, 422 Pa. 424220 A.2d 853; Ford Motor Co, v. Lonon, 217 Tenn. 400, 398 S.W.2d 240; Lascher, Strict Liability in Tort for Defective Products: The Road to and Past Vandermark, 38 So.Ca1.L.Rev. 30; Keeton, Products Liability--Liab111ty Without Fault and the Requirement of a Defect, 41 Tex.L.Rev. 855; Traynor, The Uays and Meanings of Defective Products and Strict Llability, 32 Tenn.L. Rev. 363; Wade, Strict Tort Liability of Manufacturers, 19 Sw.L.J. 5; Note, 55 Georgetown L.J. 286:2 Frumer \& Frledman, Products Liability, pp. 3-173 to 3-226.

17. Beck v. Spindler, 256 Minn. 543, 99 N.W.2d 670. 
presence and rapid discharge of the scalding water in the vaporizer far. ${ }^{18}$ At best, under the court's instructions, defendant was permitted to argue that the negligence of plaintiff's mother was a superseding cause, for it is clear that the fallure of plaintiff's parents to discover the defect or any other negligent conduct on the part of plaintiff's mother under any theory of liability cannot be imputed to plaintiff.19 The fury found against defendant on this 1ssue, and we doubt that a contrary finding could be sustained. We discover no evidentiary basis for a claim that the vaporizer was abnormally used or, Indeed, was so placed in plaintiff's room that the propensity of children to tip things over when going to the bathroom at night was deliberately or negligently lgnored, amounting to unforeseeable negligent conduct or assumption of risk by plaintiff's mother. Foreseeable intervention by a third party is not a superseding cause. 20

Finally, we come to the troublesome question of reviewability of the order conditionally granting a new trial. Plaintiff urges that we review and reverse, and defendant insists that, since judictal discretion was exerclsed in granting the order, Minn.St.605.09(e); Satter v. Turner, 257 MInn. 145, 100 N.W.2d 660; and Gothe v. Murray, 260 Minn. 181, 109 N.W.2d 350 , require a dismissal of this portion of plaintiff's attempted appeal.

It is at once evident that if we agree with defendant we are placed in the untenable position of having held the evidence adequate to sustain the verdict while at the same time permitting a new trial on all issues to occur because the trial court in the exercise of discretion, as urged by defendant, presumably found the verdict not justified by the evidence. Complicating the matter is defendant's omission to assert before this court any claim that the order could be sustained on the ground that it was based exclusively upon errors of law prejudictal to defendant or that the damages awarded were excessive for reasons requiring a retrial on all issues; that the court did not specify the grounds for the order either in the order or an explanatory memorandum; and that Rule $59.01(8)$, Rules of Civ1l Procedure, 21 provides

18. Standafer v. First Nat. Bank, 243 Minn. 442, 68 N.W.2d 362 ; Palne v. Gamble Stores, Inc., 202 Minn.462, 279 N.W. 257116 A.L.R. 407; LIndroth v. Walgreen Co., 329 I11.App. 105, 67 N.E.2d 595, affirmed, 407 I11. 121,94 N.E.2d 847.

19. Peterson v. Richfield Plaza, Inc., 252 Minn. 215, 89 N.W.2d 712.

20. Knutson v. Hielsen, $256 \mathrm{MInn}$. 506, 99 N.W.2d 215. See, also, Prosser The Fall of the C1tadel (Strict Itelifty to the Consumer), 50 Minn. L.Rev. 791,826 , for his treatment of intervening conduct to relleve a supplier of strict liabllity in tort.

21. Rule 59.01, Rules of Civil Procedure, provides: "A new trial may be granted *** for any of the following causes:

"(8) The verdict, decision, or report is not justified by the evidence or is contrary to law; but, unless it be so expressly stated in the order granting a new trial, it shall not be presumed, on appeal, to have been made on the ground that the verdict, decision, or report was not justifled by the evidence." 
that, If it was based on Insufficient evidence, "It shall not be presumed on appeal to have been made on that ground unless "1t be so expressly stated In that order."

It is true that the cases relled upon by defendant hold that a court's order conditionally granting a new trial entered pursuant to a blended motion is not reviewable of right upon an appeal from an order granting Judgment n.o.v. If $1 \mathrm{t}$ is based upon any ground enumerated in Rule 59.01 requiring the exercise of discretion and there is even the slightest doubt that fudiclal discretion was exercised. However, here the basis for the order is not disclosed and cannot be ascertained. The recent case of Ginsberg v. Williams, $270 \mathrm{Minn} .474,135$ N.W.2d 213, would permit us to hold that the order is beyond the power of the court and therefore void. In that event, the procedural status of the motion is that upon the remittitur the trial court would be required to reconsider and rule on the motion for a new trial. 22 Were a new trial ordered upon grounds other than "errors of law occurring at the trial," Minn.St. $605.09(\mathrm{e})$ would deny plaintiff an appeal of right. 23 By strict adherence to this statutory limitation, it is concelvable that plaintiff would be denied an appeal even though, despite our contrary holding, the court were to base 1 ts order upon the ground that the verdict was not Justified by the evidence. A mere recital of this procedural dilemma demonstrates its absurd conflict with the responsibilities vested in a reviewing court.

We belleve the situation presented compels us to exercise our discretionary authorfty provided by the Constitution, if not, Indeed, intended by $\$ 605.05$, subd. 2, of the new Civil Appeal Code. 24 This amendment, enacted subsequent to the cases relled upon, surely intends that once a case has been properly brought before us on appeal we may, in our discretion "review any other matter as the interests of fustice may require." In exercising this discretionary power, we are for all practical purposes overruling our decistons in Satter v. Turner, supra, and Gothe v. Murray, supra, whereln we held we could not review condttional orders granting a new trial desplte

22. Waldo v. St. Paul C1ty Ry. Co., 244 Minn. 416, 70 N.W.2d 289.

23. Minn.St, 605.09 provides: "An appeal may be taken to the supreme court:

"(e) From an order refusing a new trial, or from an order granting a new trial if the court expressly states thereln, or in a memorandum attached thereto, that the order is based exclusively upon errors of law occurring at the trial, and upon no other ground; and the court shall specify such errors in its order or memorendum, but upon appeal, such order granting a new trlal may be sustained for errors of law prejudicial to respondent other than those speclfled by the trial court."

24 Section 605.05, subd. 2, provides: "On appeal from an order the supreme court may review any order affecting the order from which the appeal is taken and on appeal from a judgment may review any order Involving the merits or affecting the judgment. It may review any other matter as the Interests of justice may require." 
our review of the orders granting judgment n.o.v. Even though there are statutory limitations on a litigant's right to a review of an order granting a new trial, the order granting fudgment n.o.v. Is clearly reviewable of right on an appeal from the judgment and both the amendment to the code and common sense dictate that we should revlew the whole order. We hold therefore that where, as here, a conditional order granting a new trial is based in whole or In part upon the insuffictency of the evidence and such issue is also ralsed and determined on review of the order granting $n .0 . v$. , we w111, if we deem the interests of fustice require, review the order in its entirety. Perhaps future cases may require broadening this exercise of discretionary review, but this holding is sufficient for this case. 25

In reversing the order, we are unable to find a ground upon which it can be upheld. As we have stated, the evidence fustifled the verdict of liabllity and also, we belleve, the award of damages. We find no errors of law occurring at trial which were prejudicial to defendant. Defendant did not specifically assign any such errors in its motion in the trial court or assert any by brlef or argument before this court. Nor is it clalmed on this appeal that the damages are excessive. We appreclate that defendant may have refrained from arguing prefudiclal error or excessive damages because of its position that the order for a new trial was not revlewable, but we have scrutinized the record with great care, resolving any doubts most favorably to defendant, and we are unable to find any procedural, evidentlary, or other errors which adversely affected defendant's substantlal rights and upon which the conditional order granting a new trlal could be sustalned.

Reversed with directions to enter judgment upon the verdict.

25. See Ginsberg v. W11l1ams, 270 Minn. 474, 476, note 3, 135 N.W.2d 213, 216, note 3, citing cases which "emphasize[d] the view that appeals pursuant to stature are rights granted to litigants by the leglslature, not 1imitations on the 'appellate jurisdiction of this court [which] is not derived from the legislature, but from the constitution (article $\$ 2) . "$ See, also, proposed amendrient to Rule 50.-02 $(4,5,6)$, Rules of Civil Procedure and Rule 103.04 subd. 2, of the proposed Rules of Civ1l Appellate Procedure. 
McCormack v. Handscraft is a typical "products liability"

case. It is indicative of a rather recent development in this area: a blurring of the line between warranty and negligence theories and the development of a "new" theory of strict liability. See Prosser, The Assault Upon the Citadel (Strict Liabilty to the Consumer), 69 Yale L.J. 1099. See also \$402A of the Restatement, Torts, 2d, quoted in footnote 15 of the McCormack opinion. Although there may be no reason for the existence of a warranty theory in products liability cases if Restatement, Torts $2 \mathrm{~d}, \$ 402 \mathrm{~A}$ is accepted by all courts, the distinction between negligence theories, warranty theories and strict liability is important to the present day lawyer. Statutes of limitation, the type and quantum of proof, rights of third parties, and conflict of laws rules may differ depending upon whether an action in brought in warranty (contract?) or tort. The court in McCormack is quite liberal in allowing the plaintiff to prove his case in strict liability even though this wasn't pleaded, but other courts might not be so tolerent.

Return, for a moment, to the question posed at the beginning of this case. Is Sylvia Coal Co. basically a different type of legal problem than McCormack? Are the interests of the plaintiff that are being protected at all similar? In Sylvia, the plaintiff was seeking to enforce a contract for the sale of goods and defendant was defending on the ground that the plaintiff had not himself performed. It is a real contract case! In McCormack, the plaintiff was seeking recovery for personal injuries. Was plaintiff really trying to enforce a contract? Was the court, in Mccormack, concerned with the business deal between plaintiff and defendant, or with compensating a consumer for injuries caused by the neglect of the plaintiff. 
Does the imposition of wararty jability or strict

liability on a seller or producer improvo the quality and safety

of products by putting pressure on a seller? if a seller knows that

he will be liable if his products do not conform to his promises, isn't he more likaly to inspent more diligontly for defective

fords"? Is this ar s"actiy way of insuring orodurt satety? Are

standarts for som, like those promolyatar for new automobiles,

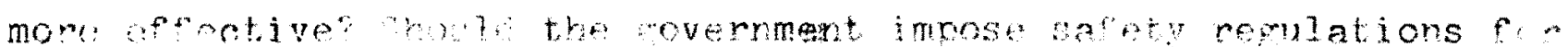

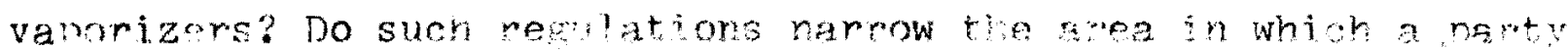

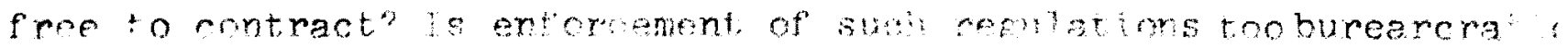

to be effective? no such molations ans th the litigant who has bor

injured by settine a atard for the prodvet thonder the follo: $\mathrm{r}$

abridement of Chapter 3 of are pinal Feocot of the National Comm:

on Product Safety which was printed in the sertember, 1970 jseuc:

Consumer seports:

\title{
Perspective on Product Safety
}

\begin{abstract}
Americans-20 million of them-are injured each year in the home as a result of incidents connecled $n$ ith consumer products. Of the total, 110,000 are permanently disabled and 30,000 are killed. A sipnificant number could have been spared if more attention hat been paid to hazard reduction. The annual cost to the nation of product-related injuries may exceed $\$ 5.5$ billion. The exposure of consumers to unreasonable consumer product lazards is excessive by any standard of measurement.

Vithin the following categories of products, we found a number of makes, models, or types harboring unreasonable hazards to the American consumer: architectural glass, color television sets, fireworks, floor fumacs, glass boltes, highrise bicycles, hot-water vaporizers, household chemicals, infant fumilute, ladders, power tools, protective headgear. rolary lawn mowers, to $s$, unvented gas heders. and wringer washers. Not all products in each category are unreasonably hazardous. Still other categories which may harbor unteasonable hazards were nol investigated in sulficient depth to warrant a specifie linding that unreatmable hazards exist.
\end{abstract}


As related to product safety, self-regulation by trade asso. ciations and standards groups, drawing upon the resources of professional associations and independent testing laboratories, is legally unenforceable and patently inadequate. Competitive forces may require management to subordinate safety factors to cost considerations, styling, and other marketing imperatives. There is a dearth of factors motivating producers toward safety. Only a few of the largest nianufacturers have coherent, articulated safety engineering programs. Manufacturers' efforts to obtain data on injuries and on the costs and benefits of design changes that will reduce unreasonable hazards can be charitably described as sketchy and sporadic.

Industry activities to develop safety standards can provide an important forum for marshaling the technical competence necessary for this work. but their voluntary nature inherently inhibits the development of optimal standards. The consensus principle. which is at the heart of all voluntary standards making, pernits the least responsible segment of an industry to retard progress in reducing hazards.

The protection afforded by various seals of approval is no better than the technical competence, product-testing prolocols, and independence of the certifier. When an in. dustry association awards the seal, or when it is awarded in return for paid advertising, the seal may convey a deceptive implication of third-party independence. Consumers appear to attribute to such endorsements a significance beyond their specific ineaning.

\section{Protection by Law}

Consumers assume that the Federal Government exereises broad reculatory authority in the interest of their safety. And yet the short answer to this question is that Federal authority to curb hazards in consumer products is virtually nonexistent. Federal product safety legislation consists of a series of isolated acts treating specific hazards in narrow product categories. No Government agency possesses general authority to ban products which harbor unreasonable risks or to require that consumer products conform to minimum safety standards.

Such limited Federal authority as does exist is scattered among many agencies. Jurisdiction over a single category of products may be shared by as many as four different departments or agencies. Moreover, where it exists, Federal product safety regulation is burdened by unnecessary procedural obstacles, circumscribed investigative powers, inadequate and ill-fitting sanctions, bureaucratic lassitude, timid administration, bargain-basement budgets, distorted priorities, and misdirected technical resources. Nevertheless, where there is adequate authority and administrative support, Federal safety standards programs have demonstrated a capacity for substantially upgrading safety practices.

The Federal Government operates no injury datis center and no early-warning system to alert responsible officials of suspected areas of latent product risk. Datit on the number and nature of injuries from consumer products remain far from satisfactory. Federal law now provides no machinery to enjoin a manufacturer from marketing consuner products that are unreasonably dangerous. There is no way to compel the recall of such products for repair or replacement. No Federal law provides meaningful criminal penalties for manufacturers who knowingly or willfully market consumer products that create an unreasonable danger to life and health. 
Our studies of Stale and local laws show a hodgepodge of tragedy-inspired responses to challenges that cannot be met by restricted geographical entities. Local prohibitions against sale of hazardous items cannot be enforced against the retailer across the city line. Manufacturers of hazardous products can make and ship out items that cannot be sold at retail in their own community. Balkanized jurisdiction plagues some manufacturers with diverse manufacturing specifications that interfere with product distribution.

The common law has been primarily concerned with postinjury remedies. There are no reports of consumers successfully restraining the marketing of potentially hazardous products. The costs of such litigation would be beyond the means of citizens or concerned groups.

\section{Injury Factors}

There are those who believe that safety, like charity, begins at home in the behavior of the family-steadying ladders, storing knives, supervising children, Others believe that safety begins with the home itself, the environment where hazardous products find their uses-good lighting, well-insulated wiring, slip-proof bathtubs and rugs, latched cabinets for medicine and household chemicals. $A$ third view is that safety begins in the factory and involves design, construction, hazard analysis, and quality control. None of these views is wholly right or wrong. With due regard for the multiple factors affecting household safety, sound strategy for a safety program is to seek the weak link in a chain of events leading to injury and to break the chain at that point.

After considering the many forces contributing to the toll of injuries in and around the American home, we have concluded that the greatest promise for reducing risks resides in energizing the manufacturer's ingenuity. We do not mean that manufacturers by themselves can do all that is needed to achieve an optimal safety record. We mean that with Government stimulation they can accomplish more for safety with less effort and expense than any other body -more than educators, the courts, regulatory agencies, or individual consumers.

Manufacturers have it in their power to design, build, and market products in ways that will reduce if not eliminate most unreasonable and unnecessary hazards. Manufacturers are best able to take the longest strides to safety in the least time. The capacity of individual manufacturers to devise safety programs, without undue extra cost, has been demonstrated repeatedly in the course of our short history: in safety glass, double-insulated power tools, baffles on rotary mowers, noncombustible TV transformers, and releases on wringer washers.

We do not imagine that, even without regard to cost, safety programs on the manufacturer's level can eliminate all household hazards. A society which uses energy in the volume and variety of forms prevalent in ours is certain to see traces of that energy go astray. Instead of doing the work intended, the energy can damage property and person. In whatever form-chemical, mechanical, thermal, electrical, 
nuclear, acoustic-energy which is misdirected cuts, strangles, burns, bruises, fractures, suffocates, poisons, shocks, and ruptures.

Danger is a regrettable but unavoidable facet of life. Many persons are keenly conscious of the hazards and take pains to control them. But everyone, at one time or another, suffers from complacency, a certainty that everything is under control, that injuries happen only to the other fellow. Then, in that moment of carefree confidence, disaster strikes. The mower goes over a grade, slips out of control, and the blades chop at the feet. Many, with utmost care, commit themselves to handling dangerous instruments which, for lack of experience, knowledge, or skill, they rannot manage. An ineradicable minority is careless; they uill wear a flammable garment near an open hire; use a power saw without a guard; work a lathe without safety glasses.

The majority of American homes contain potential electrical fire and shock hazards: worn or defective wiring, overloaded circuits, or an absence of grounding. Injuries result from dim lighting, uneven floors, irregular steps, slippery surfaces, obstacles, steep inclines. poor drainage, or faulty ventilation. Broken glass and rusty cans litter yards and alleys. Much of a child's play amounts to running a gantlet of environmental hazards.

\section{Manufacturer's Responsibility}

Prospects for measurable reform of human behavior are distant. Similarly, there is little hope for an early improvement of the home environment. The limited power of conventional educational methods has been described by our witnesses, Consequently, while continuing to educate and seeking even better ways, there seems little choice but to concentrate on reducing unreasonable hazards by encouraging additional care in the design and manufacture of products.

The law has tended in recent years to place full respon. sibility for injuries attributable to defective products upon the manufacturer. But beyond his liability for damages, a producer owes society-at-large the duty to assure that unnecessary risks of injury are eliminated. He is in the best position to know what are the safest designs, materials, construction methods, and modes of use. Before anyone else, he must explore the boundaries of potential danger from the use of his product. He must be in a position to advise the buyer competently how to use and how to maintain and repair the product.

For the following reasons, we conclude that the Federal Government, both to protect consumers and to strengthen manufacturers' efforts, should enact comprehensive legal measures to reduce hazards:

- In the absence of compulsion to reduce risks in consumer products, manufacturers who cut corners on safety have an unfair competitive advantage over responsible manufacturers.

- Manufacturers have advised us that they seek Government aid in gathering data which will help to explain injuries and their causes and Government aid to suggest priorities for preventing injuries.

- Potentially, the cost of meeting safety requirements may require sellers to raise prices above a desirable level or may impose an unwarranted and unacceptable design on a product; accordingly, Government must participate, in behalf 
of the consumer, in making the quasi-political decision of determining how much risk to safety the public should tolerate under the circumstances.

- Voluntary safety standards decided upon by an industry may unfairly penalize some manufacturers, small businessmen particularly, to the advantage of others.

- Although safety standards must be written with the assistance of technical personnel who know most about the product, Government can best determine impartially whether a safety standard is sufficient.

- When some manufacturers ignore safety standards, only Government can assure compliance. Government should enjoin actions which carelessly put the consumer in jeopardy. And, when voluntary safety standards are absent or insufficient, Government should insist that industry devise a sufficient standard or develop and issue its own.

\section{Critical Questions}

Having concluded that remedial action was essential to reduce product hazards to consumers, we faced certain critical questions:

1. Should Federal authority be extended to new programs to reduce unreasonable hazards in consumer products and, if so, what form should such authority take?

2. In view of the frustrations and disappointments characterizing some Federal efforts in behalf of the consumer, what could be done to strengthen such efforts and bolster the position of the consumer in the sometimes intricate regulatory processes?

3. What role should mandatory safety standards play in re. ducing product hazards?

And we concluded, with virtual unanimity, that-

- Broad responsibility for the safety of consumer products should be vested in a conspicuously independent Federal regulatory agency, a Consumer Product Safety Commission (CPSC), appointed by the President and confirmed by the Senate.

- There should be one official appointed hy the President as a Consumer Safety Advocate, whose primary responsibility is to serve as the consumer's spokesman before the CPSC on all issues within its jurisdiction.

- Extensive authority to issue regulations and develop mandaiory safety standards should be granted to the CPSC to anticipate or reduce unreasonable hazards in a wide range of consumer products.

Statutory regulatory programs buried in agencies with broad and diverse missions have rarely fulfilled their mis. sion. The reasons for their weaknesses include lack of adequate funding and staffing because of competition with other deserving programs within an agency; lack of vigor in enforcing the law caused by an absence of authority and independence in some Federal administrators; and a low priority assigned to programs of low visibility.

When a Federal agency must take up substantial and controversial issues of consumer safety and economics, we believe it needs independent status. Independence can be furthered by appointment of commissioners on a nonpartisan basis, for staggered fixed terms subject to removal only for cause, and by designation of a permanent chairman to serve an entire term in that capacity. 
Another reason for our recommendation of an independent Commission stems from our own experience over the past two years. As a result of our hearings and public exposure, industry took important steps for safety. Visibility has aided us in communicating public needs to business. We believe that a highly visible Consumer Product Safety Commission will have the potential to deal firmly and at arm's length with the industries it must regulate in behalf of the public.

The high visibility of a vigorous independent commission would also be a constant reminder of the Federal presence and would itself stimulate voluntary improvement of safety practices. The issues before the CPSC should be publicly aired; they are less likely to be smothered in the competition of Federal agencies for public notice. Similarly, CPSC's needs for staff and funds will receive more public attention and consideration by the Congress and by the Bureau of the Budget than those of a section of a branch of a division of a bureau of a service of an office of a department.

Finally, in developing acceptable safety standards for consumer products, it is important that manufacturers confront Government officials who, like themselves, are in command of resources and authority and able to make firm commit. ments and decisions.

\section{A Consumer Advocate}

Contrary to the common concept that "we are all consumers" and the simple assumption that a public agency always defends the public interest, in realty most in not ait public decisions represent a compromise among contending factions. Recognition of the consumer's need for representation in Government decision-making was the motivating force in the creation of the President's Special Assistant for Consumer Affairs in 1963 and for the continuance of that function in the President's Committee on Consumer Interests.

On day-to-day matters of product safety, however, the consumer has no official champion. The assumption that Federal officials represent the general public interest breaks down when, in a bargaining situation, no one bargains for the consumer. Frequently, instead of serving the consumer, the Federal agency merely provides the forum where the consumer is an affected but helpless bystander.

We believe that the highly complex issues which will face the Consumer Product Safety Commission require a specialized Consumer Safety Advocate to make the voice of the consumer heard. When the agency serves as an arbiter, seeking to reconcile contending interests, the Advocate will defend the consumer.

By institutionalizing a focus of consumer representation, it may no longer be said that "everybody's business is nobody's business."

In the absence of unreasonable risks, Federal action is unnecessary. Government should avoid needless intervention in private enterprise and the expense of developing redundant standards. At the same time, the existence of Federal authority to set mandatory safety standards may well stimulate improvements in, and compliance with, adequate voluntary standards. We have designed proposed standard-setting provisions to operate only when an identified product hazard is found and then only after a reasonable opportunity has been given to private individuals and con- 
sumer and industry groups to develop a draft standard.

The Commission must be selective, limiting its development and updating of safety standards to categories of consumer goods which contain an unreasonable risk or the threat thereof. When the need for action is apparent, the writing of safety standards must not drag on for months. A standard must be completed as quickly as governmental and private resources permit. We have provided in the proposed system that the Commission may make an interim product safety standard effective inmediately where it finds an imminent risk to safety.

In the event that private sources fail to frame a needed and adequate standard, the CPSC must have its own technical resources and authority to tap personnel and facilities of the Federal Government and private sources to develop mandatory safety standards. Safety standards cannot be deferred until all makers of a product are satisfied; dissatisfied manufacturers will be able to appeal what they consider unjustifiably stringent standards to the CPSC or, ultimately, to the courts.

\section{Digest of Recommendations}

It is not the number or kinds of injuries but the fact of injury-the chronic disability, the mental anguish, the burden of medical costs, and the economic waste-that demands remedial action to reduce unreasonable product hazards by the most direct and efficient means.

By way of remedy, our recommendations provide:

That the Consumer Product Safety Commission be directed to secure voluntary cooperation of consumers and industry in advancing its programs and that, when necessary to protect consumers from unreasonable risks of death or injury, the Commission be empowered to-

- Enforce compliance with consumer product safety standards through a broad range of civil and criminal sanctions.

- Enjoin distribution or sale of consumer products which violate Federal safety standards or which are unreasonably hazardous.

- Require notice to consumers of substantially defective products, and recall of products which violate consumer product safety standards or which are unreasonably dangerous.

- Make reasonable inspections of manufacturing facilities to implement compliance with safety standards and regulations.

- Conduct public hearings and subpoena witnesses and documents.

That the Commission be given further responsibility to-

- Establish an Injury Information Clearinghouse to collect and analyze data on deaths and injuries associated with consumer products.

- Disseminate information to the public about hazardous consumer products and practicable means of reducing hazards.

- Cooperate with and assist States and localities in programs germane to consumer product safety. 
That the Commission, in cooperation with the Secretary of Commerce, be authorized to accredit private testing laboratories which are qualified to test and certify compliance with specific product safety standards, and that the Commission be empowered to require independent testing of consumer products which may present an unreasonable risk.

That the Federal Trade Commission promulgate trade regulation rules for those who certify or endorse the safety of consumer products.

That Federal agencies provide industry and standards. setting groups with relevant technological information which may be utilized to reduce product hazards.

That the Commission be authorized and afforded funds for the construction and operation of a facility suitable for research, development of test methods, and analysis of consumer products for safety considerations.

That the Federal Government, through its purchasing and insuring agents, look to established safety standards and, wherever practicable, new safety designs in selecting products for use, and that Federal agencies publicize acquired information about hazards in consumer products.

That injured consumers be permitted to file claims for treble damages in the District Courts of the United States against manufacturers who intentionally violate Federal safety standards; that Federal class action procedures be made applicable; and that the principles of strict tort liability be adopted by State and Federal courts to assure fair compensation for injury to consumers in suits at common law.

That consumer products for import into the United States be denied entry if they violate Federal safety standards and that export of consumer products which do not meet Federal safety standards be prohibited unless waiver is obtained from a responsible official of the country of destination.

That the United States support the development of international consumer product safety standards, and assure fair representation of consumer interests in such proceedings. 
Misrepresentation and Deceit

Restatement of Contracts I

\$ 470. Definition of Misrepresentation; When Misrepresentation Is Material.

(1) "Misrepresentation" in the Restatement of this Subject means any manifestation by words or other conduct by one person to another that, under the circumstances, amounts to an assertion not in . accordance with the facts.

(2) Where a misrepresentation would be likely to affect the conduct of a reasonable man with reference to a transaction with another person, the misrepresentation is material, except as this definition is qualified by the rules stated in $\$ 474$.

\section{Comment:}

a. Misrepresentation of itself implies neither conscious error nor negligence on the part of the person making the misrepresentation. It may be innocent or known to be false, material or immaterial, negligent or free from negligence; it may be intended or expected to influence conduct, or it may not; it may be by words or any other acts. It never produces legal consequences unless it induces another person to act or refrain from acting.

$b$. The word "facts" in the Section is given its broadest meaning. In this sense, a rule of law is a fact; knowledge is a fact and an assertion of knowledge when knowledge does not exist is an assertion not in accordance with the facts; and indecd any state of mind is a fact. The limitation in $\S 474$, however, often makes such misrepresentations immaterial.

c. "Transaction" in the Restatement of this Subject includes the formation, performance or discharge of a contract, the assignment of a right under a contract, and also facts that would have amounted to any of these if it were not for a mistake, or some wrongful. act of one of the parties.

\$ 471. Definition of Fraud.

"Fraud" in the Restatement of this Subject unless accompanied by qualifying words, means 
(a) misrepresentation known to be such, or

(b) concealment, or

(c) non-disclosure where it is not privileged, by any person intending or expecting thereby to cause a mistake by another to exist or to continue, in order to induce the latter to enter into or refrain from entering into a transaction; except as this definition is qualified by the rules stated in $\S 474$.

\section{Contment:}

a. "Fraud" is a word used in more than one branch of the law, and the meaning with which the word is used in various branches is not always identical. Fraud as a tort is not here defined. Nor are fraud against creditors and fraud against subseçuent purchasers within the definition in the Section. Where such fraud is referred to in the Restatement of this Subject, the word fraud is always accompanied by qualifying words.

$* * * * * * * * * * * * * * * * * * *$

"Misrepresentation runs all through the law of torts, as a method of accomplishing various types of tortious conduct which, for reasons of historical development or as a matter of convenience, usually are grouped under categories of their own. Thus a battery may be committed by feeding the plaintiff poisoned chocolates, or by inducing his consent to a physical contact by misrepresenting its character; false imprisonment may result from a pretense of authority to make an arrest; a trespass to land from fraudulent statements inducing another to enter, or a conversion from obtaining goods by false representations; and a malicious lie may give rise to a cause of action for the intentional infliction of mental suffering resulting in illness. A great many of the common and familiar forms of negligent conduct, resulting in invasions of tangible interests of person or property, are in their essence nothing more than misrepresentation, from a misleading signal by an automobile driver about to make a turn, or an assurance that a danger does not exist, to false statements, or nondisclosure of a latent defect by one who is under a duty to give warning. In addition, misrepresentation may play an important part in the invasion of intangible interests, in such torts as defamation, malicious prosecution, or interference with contract relations. In all such cases the particular form which the defendant's conduct has taken has become relatively unimportant, and misrepresentation has been merged to such an extent with other kinds of misconduct that neither the courts nor the legal writers have found any occasion to regard it as a separate basis of liability.

"So far as misrepresentation has been treated as giving rise in and of itself to a distinct cause of action in tort, it has been identified with the common law action of deceit. The reasons for the separate development of this action, and for its peculiar limitations, are in part historical, and in part connected with the fact that in the great majority of the cases which have come before the courts the misrepresentations have been made in the course of a bargaining transaction between the parties. Consequently the action has been colored to a considerable extent by the ethics of bargaining between distrustful adversaries. Its separate recognition has been confined in practice 
very largely to the invasion of interests of a financial or commercial character, in the course of business dealings.

"Tliere is no essential reason to prevent a deceit action from being maintained, for intentional misstatements at least, where other types of interests are invaded; and there are a few cases in which it has been licld to lic for personal injuries, for tricking the plaintiff into an invalid marriage [Tuck v. Tuck (1964) 14 N.Y.2d 341, 200 N.E.2d 554], or marriage with one who is physically unfit, or for inducing the plaintiff to leave a husband, or to incur criminal penalties. In general, however, other theories of action have been sufficient to deal with nonpecuniary damage, and the somewhat narrower theory of deceit is not called into question. The typical case of deceit is one in which the plaintiff has parted with money, or property of value, in reliance upon the defendant's representations.

"The law of misrepresentation is, however, considerably broader than the action of deceit. Liability in damages for misrepresentation, in one form or another, falls into the three familiar divisions with which we have dealt throughout-it may be based upon intent to deceive, upon negligence, or upon a policy which requires the defendant to be strictly responsible for his statements without either. For the most part, the courts have limited deceit to those cases where there is an intent to mislead, and have left negligence and strict liability to be dealt with in some other type of action. There has been a great deal of overlapping of theories, and no little confusion, which has been increased by the indiscriminate use of the word 'fraud,' a term so vague that it requires definition in nearly every case. Further difficulty has been added by a failure to distinguish the requisites of the action at law in tort from those of equitable remedies, and to distinguish the different forms of misrepresentation from one another, and misrepresentation itself from mere mistake. Any attempt to bring order out of the resulting chaos must be at best a tentative one, with the qualification that many courts do not agree." Prosser, Torts, 3d ed. (1964) 697-699.

Misrepresentation is thus a very complex field. The complexity results in no small part from the fact that in most cases the plaintiff has alternative remedies available, which are based upon different theories, and have developed along different lines. The more important of these alternatives are as follows:

1. The tort action of deceit, with whieh this chapter is primarily coneernect. :

2. An action for breach of contract, where the representation is found to be an express or implied term of the contract itself. In the case of the sale of chattels, this may take the form of an action for breach of warranty, which, as previously noted, has definite tort characteristics of its own. The contract liability is of course a strict 
one, and requires no intent to deceive, negligence, or other fault than the breach of the contract itself.

3. A negligence action, for negligent misrepresentation. This is now recognized by nearly all courts where tangible injury to person or property results, and by many of the American jurisdictions where the only damage is financial loss. It involves distinct problems of the extent of liability, or "duty" and "proximate cause." It may be open to the defense of contributory negligence where the deceit action would not.

4. A suit in equity to rescind the transaction, or for other relicf such as an equitable lien or a constructive trust. The equity courts, which were not bound by rules adopted at common law, have been as much concerned with the inequity of allowing the defendant to retain what he has received through the plaintiff's erroncous belicf in the truth of his statement as with the wrongfulness of the original conduct. Hence they have afforded a remedy for innocent misrepresentation, or even for mutual mistake as to a basic fact, not induced by misrepresentation at all. The equity suit is, however, subject to restrictions peculiar to equity -as that the plaintiff must himself do equity by restoring whatever he has received, must act without undue delay, and must do nothing inconsistent with the relief demanded.

5. An action at law, to recover back what the plaintiff has parted with, or the unjust enrichment which the defendant has received from it. This type of restitution action developed late in the eighteenth century when the common law courts, seeking to broaden their jurisdiction into equitable fields, took over principles of equity. By the fiction of an implied promise to pay what was due in good conscience, the plaintiff was permitted to rescind the transaction of his own motion, or, as it usually was phrased, to "waive" the tort and sue in assumpsit. In later cases the principle was extended to permit the plaintiff to maintain even a property action, such as replevin, for specific goods surrendered to the defendant. The law courts adhered to the rules of equity, and the restitution action is, in general, governed by the same principles as the equity suit.

6. The defense of "fraud," or misrepresentation, when the party deceived is sued on the contract. Two distinct theories are discoverable in the cases. One is an "equitable" defense, by which the party deceived rescinds the transaction, tenders back whatever he has received, and seeks to avoid liability. The other is something analogous to a tort action of deceit, set up by way of defense to avoid circuity of action, by which the party "recoups", or reduces the damages recoverable from him, or even avoids all liability. The two theories are not at all clearly distinguished, and further confusion has resulted from rules of pleading, which at one time did not permit equitable defenses to be pleaded in actions at law. 
7. Estoppel, by which the party misrepresenting a fact is mecluded from denying in court that his representation was true. It alppears most frequently as a defense to an action brought wy the party to be estopped; but, while it never has been recognized as a cause of action in itself, it may serve as an important aid to the plaintiff's action. Thus where a warehouseman represents to a prospective purchaser of goods that he holds them for the seller, he mar find himself estopped to deny the truth of his statement when the purchaser seeks to recover the goods from him.

There has been a great deal of confusion as to thre various remedies, and rules, concepts, principles, language and ideas appropriate to one have unfortunately been carried over to ofhers where they are not appropriate at all. The cases which follow are mimarily concerned with the tort action of deceit; but no clear idea of misrepresentation is possible without reference to the different rules to be applied in connection with the other remedies.

History. The action of deceit is of very ancient origin. There was an old writ of deceit known as early as 1201, which lay only in cases of what we should now call malicious prosecution. At a later period this writ was superseded by an action on the case in the nature of deceit, which became the general common law remedy for any misrepresentation, whether fraudulent or not, which resulted in actual damage. It was used to afford a remedy for many wrongs which we should now regard as breaches of contract, such as false warranties in the sale of goods. Its use was limited almost entirely to direct transactions beween the plaintiff and the defendant, and it was treated as inseparable from some contract relation. In other words, tort and contract were not at all clearly distinguished.

The bargaining ethics of that day were low. It was assumel that all sellers would lie, and if the buyer wanted protection he was expected to exact from the seller an express undertaking to be responsible, such as a warranty. "Caveat emptor"-let the buyer look out for himself. Thus in the picturesque old case of Chandelor v. Lopus, (1603) Cro.Jac. 4, 79 Eng.Rep. 3, a goldsmith sold a stone to the plaintiff, falsely stating that it was a bezar stone-a "calcareous concretion in the stomach of a goat," believed to have medicinal properties, particularly as a remedy against snake-bite. It was held that there was no liability, even though the seller knew his statement to be false, in the absence of an express undertaking to be bound.

In 1789, in Pasley v. Freeman, 3 Term Rep. 51, 100 Eng.Rep. 450, the action of deceit was held to lie in a case where the plaintiff had had no dealings with the defendant, but had been induced by his misrepresentation to extend credit to a third person. After that date deceit was recognized as purely a tort action, and not necessarily founded upon a contract. At about the same time, in Stuart v. Wilkins (1778) 1 Dougl. 18, 99 Eng.Rep. 15, the remedy for breach of warranty was taken over into the artion of assumpait, and it was thus established that it had a contract character. Thereafter the two lines of recovery slowly diverge, although some vestige of confusion between the two still remains, even today.

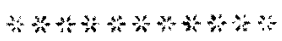


§ 474. MANIFESTATION OF OPINION AS FRAUD OR MISREPRESENTATION.

A manlfestation that the person making has no reason to expect to be understood as more than an expression of his op inlon, though made also with the intent or expectation stated in 5471 , is not fraud or a material misrepresentation, unless made by

(a) One who has, or purports to have expert knowledge of the matter, or

(b) one whose manifestation is an Intentional misrepresentation and

varles so far from the truth that no reasonabie man in his

position could have such an op Inion.

$* * * * * * * * * * * * * *$

VULCAN METALS CO., INC., V. SIMMONS MFG. CO.

VULCAN METALS CO., InC., et al. $v$. SAME.

(Circult Court of Appeals, Second Circult. January 7, 1918. On Petition of Plaintiffs in Error for a Rehearing, February 13, 1918)

248 Fed. 853

In Error to the District Court of the United States for the Southern District of New York.

Action by the Vulcan Metals Company, Incorporated, against the Simmons Manufacturing Company, begun in the state court and removed to the federal court, together with an action by the simmons Manufacturing Company agalnst the Vulcan Metals Company, Incorporated, and Albert Freeman, who counterclaimed. There was a judgment for the Simmons Manufacturing Company, defendant in the first action, and for it as plaintiff in the second, the counterclaim of the defendants Vulcan Metals Company, Incorporated, and Albert Freeman being dismissed, and the Vulcan Metals Company, Incorporated, and another bring error. Judgment in the action by the Vulcan Metals Company reversed, and judgment in action on notes modifled, so as not to dismiss the counterclaim on the merits, and otherwise affirmed.

"Writ of error to two judgments of the District Court for the Southern District of New York, entered in the first case upon a verdict directed by the court dismissing the complaint, and in the second case, upon a verdict directed by the court in favor of the plaintiff for the sum of $\$ 43,423.04$. The complaint in the first action was for decelt, brought in the state court and removed for diversity of citizenship to the District Court. The complaint in the second was originally brought in the District Court, about a month after the first sult, and was upon three notes, for $\$ 15,000, \$ 12,500$, and $\$ 12,500$, respectively. In the complaint on the second action the defendants set up the same facts whlch they laid in their complaint in deceit, and which they here pleaded as a defense to the action on the notes and as a counterclaim. 
"The gist of the complaint in the first action was the fraudulent procurement by the Simmons Manufacturing Company of a contract executed by the defendant Freeman on behalf of the Vulcan Metals Company, Incorporated, by which he purchased from the Simmons Company for $\$ 75,000$ all the tools, dies, and equipment owned by it for the manufacture of its vacuum cleaning machines, all manufactured machines and unassembled parts, as set forth in a schedule thereto attached, and all inventions, applications, and letters patent owned by the Simmons Company in vacuum cleaners, together with certain proposed improvements to be made thereon. The complaint further alleges that the officers and agents of the simmons Manufacturing Company made false representations as to the character of the vacuum cleaners so sold and the extent to which they had been used upon the market, to which the Vulcan Metals Company, Incorporated, acted to its prejudice, because the machines and patents were totally inefficlent and unmarketable. The notes sued on in the second cause of actlon were three of those given as part of the purchase price. The Distrlct Judge directed a verdict for the Simmons Manufacturing Company in both actions, upon the theory that no actionabie fraud had been made out, and the correctness of this rulling is the turning point in the case.

"The plaintiff in the first action was a corporation, of which Albert Freeman, one of the defendants in the second action, was a promoter. He was an indorser of the notes, and conducted the negotlations whlch resulted in the purchase by him of the vacuum cleaners on behalf of the plaintiff. He testifled to certain representations made to him at the time as an inducement to his entering into the contract. These representations emanated in the first instance from one Flynn, who had been apparently authorized by the Simmons Manufacturing Company to act as a broker in the sale of the mach ines and the patents. Flynn's authority to represent the Simmons Manufacturing Company in respect of such representations would be a turning point in the case, except for the fact that Freeman swore that the president of the company, one Simmons, and its general counsel, Barnes, had repeated all of Flynn's statements during the negotlations and that he had relled upon them. It therefore became essential to determine, since Simmons was clearly authorlzed to represent the Simmons Manufacturing Company, whether the misrepresentations would support an action of deceit. They were of two classes -- those touching the efficiency of the vacuum cleaner; and, second, that no attempt had been made to market the machines by the Simmons Manufacturing Company.

\footnotetext{
"The first of these classes is substantially the same as those contained In a booklet issued by the Simmons Manufacturing Company for the general sale of the vacuum cleaners. They include commendations of the cleanliness, economy, and efficlency of the machine; that it was absolutely perfect in even the smallest detall; that water power, by whlch It worked, marked the most economical means of operating a vacuum cleaner with the greatest efficlency; that the cleaning was more thoroughly done than by beating or brushing; that, having been perfected, it was a necessity which every one could afford; that it was so simple that a child of six could use it; that it worked completely and thoroughly; that it was simple, long-lived, easily operated, and effective; that it was the only sanitary portable cleaner on
} 
the market; that perfect satisfaction would result from its use; that it would last a lifetime; that it was the only practical jet machine on the market; and that perfect satisfaction would result from its use, if properly adjusted. The booklet is in general the ordinary compilation, puffing the excellence and powers of the vacuum cleaner, and asserting its superiority over all others of a similar sort. Flynn made a demonstration of the cleaner to Freeman with borax sprinkled upon the carpet, and allowed him to take one for experiment, which he retained for some time.

"The second class of misrepresentations was that the Simmons Manufacturing Company had not sold the machine, or made any attempt to sell it; that they had not shown it to any one; that it had never been on the market, and that no one outside of the company officials and the men in the factory knew anything about it; that they had manufactured 15,000 of them, but before making any attempt to market it they had been told by their agent that it would be a mistake for them to attempt to sell these along with their ordinary line, which was furniture; that on that account they had withdrawn them from the market and had never made any attempt to put them out. Sweetland, one of the promoters of the Vulcan Metals Company, Incorporated, swore that Flynn had stated that the machines had been marketed, but marketed successfully. There was therefore a discrepancy between the testimony of these two representations, but for the purposes of the action it is not here material, since the complaint was based upon the representation that the machines had not been sold.

"There was evidence that the machines, when exploited by the Vulcan Metals Company, Incorporated, proved to be ineffective and of little or no value and that their manufacture was discontinued by that company not very long after they had undertaken it. There was also evidence that several of the Western agents of the Simmons Manufacturing Company had had the machines in stock and had attempted to market some of them; that they had been unsuccessful in these efforts, owing for the most part to the fact that the water pressures, where they had been sold, had not been sufficient to establish the necessary vacuum. Just what the vacuum was in the places where the machines were unsuccessful did not definitely appear in any of the proof."

Wilson B. Brice, of New York City (Charles H. Hyde, of New York City, of counsel), for Vulcan Metals Co., Inc.

Sullivan \& Cromwell, of New York City (Clarke M. Rosecrantz and E. H. Sykes, both of New York City, of counsel), for Simmons Mfg. Co.

Before WARD and HOUGH, Circuit Judges, and LEARNED HAND, District Judge.

LEARNED HAND, * District Judge (after stating the facts as above). [1] The first question is of the misrepresentations touching the quality and

*Learned Hand (1872-1961) was one of the most famous of American judges. His father, Samuel, his grandfather, Augustus, and his cousin, Augustus Nobel Hand, were all judges. Learned, named after his mother's maiden name, sat on the U.S. District Court from 1909 to 1924 and on the U.S. Court of Appeals from 1924 to 1951. His books include The Spirit of Liberty (1952) and The Bill of Rights (1958). Some of his outstanding decisions are contained in Shenks, The Art and Craft of Judging (1968). 
powers of the patented machine. These were general commendations, or, in so far as they included any specific facts, were not disproved; e.g., that the cleaner would produce 18 inches of vacuum with 25 pounds water pressure. They raise, therefore, the question of law how far general "puffing" or "dealers" talk" can be the basis of an action for deceit.

The conceded exception in such cases has generally rested upon the distinction between "opinion" and "fact"; but that distinction has not escaped the criticism it deserves. An opinion is a fact, and it may be a very relevant fact; the expression of an opinion is the assertion of a belief, and any rule which condones the expression of a consciously false opinion condones a consciously false statement of fact. When the parties are so situated that the buyer may reasonably rely upon the expression of the seller's opinion, it is no excuse to give a false one. Bigler $v$. Flickinger, $55 \mathrm{~Pa}$. 279. And so it makes much difference whether the parties stand "on an equality." For example, we should treat very differently the expressed opinion of a chemist to a layman about the properties of a compcsition from the same opinion between chemist and chemist, when the buyer had full opportunity to examine. The reason of the rule lies, we think, in this: There are some kinds of talk which no sensible man takes seriously, and if he does he suffers from his credulity. If we were all scrupulously honest, it would not be so; but, as it is, rieither party usually believes what the seller says about his own opinions, and each knows it. Such statements, like the claims of campaign managers before election, are rather designed to allay the suspicion which would attend their absence than to be understood as having any relation to objective truth. It is quite true that they induce a compllant temper in the buyer, but it is by a much more subtle process than through the acceptance of his claims for his wares.

So far as concerns statements of value, the rule is pretty well fixed against the buyer. So. Dev. Co. v. Silva, 125 U.S. 247, 256, 8 Sup. Ct. 881 , 31 L. Ed. 678; Gordon v. Butler, 105 U.S. 553, 26 L. Ed. 1166; Lehigh Zinc, etc., Co. v. Bamford, 150 U.S. 665, 14 Sup. Ct. 219,37 L. Ed. 1215. It has been applied more generally to statements of quality and serviceability. Kimball v. Bangs, 144 Mass. 321, II N.E. 113; Neidefer v. Chastain, 71 Ind. 363, 36 Am. Rep. 198; Warren v. Doolittle, 61 111. 171; Hunter v. McLaughlin, 43 ind. 38. But this is not always so. lowa, etc., Co. v. Amer. Heater Co. (C.C.) 32 Fed. 735. As respects the validity of patents it also obtains. Reeves v. Corning (C.C.) 51 Fed. 774; Dillman v. Nedlehoffer, 1191111.567 , 7 N.E. 88; Huber v. Guggenheim (C.C.) 89 Fed. 598. Cases of warranty present the same question and have been answered in the same way. Chalmers $v$. Harding, $17 \mathrm{~L}, T$. (N.S.) 571; Farrow v. Andrews, 69 Ala. 96; Bain v. Withey, 107 Ala. 223; Gaar, etc., Co. v. Halverson, 128 lowa, 603, 105 N.W. 108; Bartlett v. Hoppock, 34 N.Y. 118, 88 Am. Dec. 428. Contra, Elkins v. Kenyon, 34 Wis. 93.

In the case at bar, since the buyer was allowed full opportunity to examine the cleaner and to test it out, we put the parties upon an equality. It seems to us that general statements as to what the cleaner would do, even though consciously false, were not of a kind to be taken literally by the buyer. As between manufacturer and customer, it may not be so; but this was the case of taking over a business, after ample chance to investigate. 
Such a buyer, who the seller rightly expects will undertake an independent and adequate inquiry Into the actual merits of what he gets, has no right to treat as materlal in his determination statements like these. The standard of honesty permitted by the rule may not be the best; but, as Holmes, J., says In Deming v. Darling, 148 Mass. 504, 20 N.E. 107, 2 L.R.A. 743, the chance that the hlggling preparatory to a bargain may be afterwards translated into assurances of quality may perhaps be a set-off to the actual wrong allowed by the rule as it stands. We therefore think that the Distrlct Court was right in disregarding all these misrepresentations.

$[2,3]$ As respects the representation that the cleaners had never been put upon the market or offered for sale, the rule does not apply; nor can we agree that such representatlons could not have been material to Freeman's declsion to accept the contract. The actual test of experience in their sale might well be of critical consequence in his declsion to buy the buslness, and the jury would certainly have the right to accept his statement that his reliance upon these representations was determinative of his final decision. We believe that the facts as disclosed by the depositions of the Western witnesses were sufficient to carry to the jury the question whether those statements were false. It is quite true, as the District Judge said, that the number of sales was small, perhaps not 60 in all; but they were scattered in varlous parts of the Mountain and Pacific States, and the jury mlght conclude that they were enough to contradict the detalled statements of simmons that the machines had been kept of $f$ the market altogether.

The Simmons Manufacturlng Company inslsts that there was no evidence that Simmons, who was the only party authorized to speak for that company, knew that the goods had ever been put on sale, and it is quite true that there was no such direct evidence. It is at least arguable whether the evidence was sufficient to allow a jury to say that simmons had known of these efforts. The results of the sales seem to have come to the knowledge only of the local agents, but we think a jury might say that the fact of their sale and the decision of the agents to sell them might have been authorized by the home office, and that simmons might have known of both. While, therefore, if the case turned only upon Simmons' knowledge of the failure of the machines upon sale, we should hardly think the evidence sufficient to justify any inference that he dld know, yet, since the fraud alleged was of the fact of sale alone, the evidence did not justify a directed verdict. Such a misrepresentation might have been material to Freeman in the execution of the contract, since, if he did learn that they had been on sale, he might well have insisted that the results of those sales should be disclosed before he proceeded. Sweetland's testimony to the contrary only discredits Freeman's statements; it cannot be itself the basis of any recovery.

[4-6] The next question is as to whether any such misrepresentations were concluslvely cured by the recital in the contract of purchaseas follows:

The party of the first part[the Simmons Company] has been engaged in the manufacture of a certain type of vacuum cleaning machines, and the parties of the first and second part [the National Suction Cleaner Company] have been engaged In the sale thereof. 
We all agree that an adequate retraction of the false statement before Freeman executed the contract would be a defense. Whether this be regarded as terminating the consequerices of the original wrong, or as a correction of it, is of $11+t l e$ importance. Further, we agree that, even if Freeman had in fact never learned of the retraction, it would serve, if given under such circumstances as justified the utterer in supposing that he would. For example, a letter actually dellvered into his hands containing nothing but a retraction would be a defense, though it abundantly appeared that he had never read It. HIs loss might still be the consequence, and the reasonable consequence, but for the letter, of the original fraud; but the writer would have gone as far as necessary to correct that fraud, and we should not be disposed to hold it as an insurer that its correction should be effective. Judge WARD and 1, however, do not think that such a recital in such a place was certain to catch the eye of the reader, and that therefore neither was the defendant's duty of retraction inevitably discharged, nor, what is nearly the same thing, did the defendant show beyond question that Freeman actuallysaw it. As a retraction the recital was a defense, and the defendant had the burden of proof. As notice to Freeman actually conveyed, it may have been only evidence upon the causal sequence between the wrong and the injury; but we attach no great significance to that distinction. The fact that he signed the contract appears to us to be some evidence upon which the jury might say that he could not tave seen the recital. That depends upon how much importance they think he attached to the original representation, and that depends in turn upon what they thought of his story. If they did belleve that the representation was of critical consequence in his decision, they might infer that he did not see it, or he would not have gone on without some explanation. The very silence of the testimony upon the question might be taken to infer that he had not noticed it, even at the trial, just as it might also be taken to indicate that lie had fabricated the whole story, and hoped the recital would escape the notice of the defendant. In any event, the interpretation of the whole transaction appears to us not to be so clear that reasonable people might not come to opposite conclusions upon it, and that involves a submission to the jury. It is perhaps of some importance that no allusion to the recltal appears in the record.

$[7,8]$ It results from the foregoing that the judgment in the action for deceit must be reversed. In the action upon the notes the judgment upon the notes will be affirmed, because the Vulcan Metals Company, Incorporated, did not make any offer to return the machines, tools, and patents, which were not shown to be without any value, and consequently it was in no position to rescind. The judgment in that action dismissing the counterclaim must, however, be reversed, since the counterclaim involved the same facts as the complaint in the action for deceit. Flynn's agency appears in this record only by his declarations, and he was not shown to have any authority to speak for the simmons company. He was at most only a broker, and as such his representations in the negotiations as to the prior conduct of the Simmons Company touching sales of machines were not with in his authority. The same applies upon this record to Barnes, the general counsel of the defendant. The proof of thelr authority may, of course, be different upon the next trial, as to which we naturaliy have nothing to say. 
However, no representations should be allowed as to the efficiency, durability, or economy of the cleaners, and the case should be tried upon the sole issue whether the defendant, through duly authorized agents, represented to Freeman that the goods had not been put on sale when in fact they had, whether this representation was material to Freeman's execution of the contract, whether the insertion of the recital into the contract was all that was reasonably necessary by way of retraction, and, if not, whether Freeman did not actually read it in the contract.

Judgment in the action of deceit reversed, and new trial ordered. Judgment in the action on the notes affirmed so far as it gives judgment on the notes, and reversed so far as it dismisses the counterclaim, and new trial upon the counterclaim ordered.

HOUGH, Circult Judge (dissenting in part). The one polnt on which 1 cannot agree with the majority is the effect of the statement (it makes no difference whether it is called a "recital" or by some other name) contained in a contract which was signed by Freeman before he suffered any loss and at the moment he entered into obligation. The opinion of the court holds that this retraction or correction cannot be judiclally held adequate or sufficient to conclude Freeman, if "in fact [he] did not see it." But he never denied seeing it; and the majority holding is in efiect that, though signature of contract is admitted, and reading of all of it not denled, yet, in the absence of a speciflc admission of reading with comprehension, a case was made for the jury, because there is no presumption of reading, or at least of the intelligent reading, of an admittedly signed contract.

A man is held to be bound by a contract because he is presumed to know what it means and says; as the greater includes the less, I should consider him bound to a comprehension of the ordinary meaning of the words employed. The present rulling seems to me but a direction as to how to give evidence upon another trial.

\section{On Petition of Plaintiffs in Error for a Rehearing.}

PER CURIAM. We have concluded that the judgment in this action on the notes should be modified, so as to affirm the money judgment in favor of the plaintiff below, and to dismiss (but not upon the merits, as was done below) the counterclaim interposed. This counterclaim is substantially the action for decelt. That it did not constitute a defense was sufficlently set forth in our prevlous opinion.

[9] Whether the same allegations of fact can be used as a counterclaim is a question that depends upon the construction of section 501 . Code Civ. Proc. N.Y. The cause of action is on the contract evidenced by the notes in suit; the counterclaim is in tort, and therefore the question is whether such tort cause of action arises out of the transacilion set forth in the complaint or is "connected with the subject of the action." UnderIylng and governing this question of procedure is the legal fact that this action of deceit presupposes and recognizes a contract valid and enforceable. If there was not such a contract, this particular action of 
deceit could not exist, and no effort is or can be made in this proceeding to set aside, invalidate, or nullify either the contract evidenced by the notes or the contract out of which the notes arose. That this counterclaim did not, in the language of the statute, arise out of the contract or transaction set forth in the complaint, is too plain for argument; whether it is "connected with the subject of the action" is a question which we resolve in favor of plaintiff below. The question is often difficult, but, as was said in Carpenter v. Manhattan, etc., Co., 93 N.Y. 556. "the counterclaim must have such relation to and connection with the subject of the action that it will be just and equitable that the controversy be settled in one action. If a more rigid or formal test be looked for, the best is that of reciprocity. Adams v. Schwartz, 137 App. Div. 235, 122 N.Y. Supp. 41 , and cases clted.

Making application of this test, could the payees of the notes, when sued in deceit, set up the notes as a proper counterclaim? Certainly not. The action of the lower court in dismlssing the counterclaim on the merits naturally followed from its disposition of the action of deceit; the writ of error herein complained of what was done. We sustain the writ only in so far as the counterclaim was dismissed on the merits, mo "ying the judgment below by striking out those words. The judgment is onierwise affirmed.

LEARNEO HAND, District Judge (dissenting). I think the judgment on the notes should be reversed, along with the judgment on the counterclaim, and that both should go back for the new trial. 
HEDIN $\nabla$. MINNEAPOLIS MEDICAL \&

SURGICAL INST, et a1.

(Supreme Court of Minnescta. Aug. 6, 1895)

62 Minn. 146,64 N.W. 158

Appeal from district court, Hennepin county; Henry G. Hicks, Judge.

Action by Peter Hedin against the Minneapolis Medical \& Surgical Institute and others for deceit. There was a verdict for plaintiff, and, from an order denying their motions for new trial, defendants severally appea1. Affirmed.

Chas. G. Laybourn, for appe1lants. W. A. Lancaster and Lancaster \& Bush for respondent.

COLLINS, J. This is an action for decelt. Defendant institute is a corporation, while defendant Lawrence is its president, the physictan and surgeon in charge, and the person with whom plaintiff dealt, and to whom he pald the sum of $\$ 500$ for medical treatment, whlch sum he alleges was obtained by defendants through false and fraudulent representations to him that certain injuries from which he was then suffering were curable, and that at the institute they could and would cure him for that amount of money. No question has been made as to the sufficlency of the complaint. Plaintiff had a verdict for $\$ 500$ and interest, and defendants severally appeal from an order refusing a new trial. Thirty-seven errors have been speclfled in appellants' brief, nearly all relating to the rulings of the trial court when the evidence was being taken. We have examined these spectfications of error with care, and, notwithstanding the elaborate argument and evident sincerlty of defendants' counsel, we are compelled to say that very few are entitled to spectal reference. The real question in the case is as to the sufficlency of the evidence to support the verdict, and this depends malnly on an inquiry as to whether the statements and representations alleged to have been made, and sald to have been relied upon, were actionable. According to the evidence, these were made by defendant Lawrence, and to the effect that the plaintiff's injurles could be cured, and that he could and would be made sound and well if he placed himself under treatment at the instltute. Counsel for defendant contends that, at most, these statements were but expressions of opinton as to matters contingent and uncertain in their very nature, not susceptible of certain determination or of actual ascertalnment: therefore no action as for decelt can be maintalned upon them. To sustain such an action, it must be shown that a false representation of a materlal fact has been made, In 1gnorance relied upon, and that damage has ensued. The representation must be fraudulently made, an intention to deceive being a necessary element or ingredient. But positive proof that a party knew his representation to be untrue is not essentlal. The intenticn may be proved by showing that, having no knowledge of the truth or falsity of his statements, he did not believe them to be true, or by showing that, having no knowledge of their truth or falsity, yet he represented them to be true, of his own knowledge. When the knowingly false assertion is as to the bellef of a party, or is as to his knowledge of the fact he assumes to announce, Intent to deceive is the inevitable inference. If this defendant Lawrence made statements and representations to plaintiff that his injurles were curable, and that with treatment he could become a well and sound man, having no knowledge of the truth or 
falsity of his statements, and not belleving them to be true, or if he made such statements, having no knowledge of their truth or falsity, yet representing that they were true, the intent to decelve 18 as well established as If positive knowledge of their untruthfulness had been proven. Generally speaking, the representations must be as to a materlal fact, susceptible of knowledge: and, if they appear to be mere matters of opinion or conjecture, they are not actionable. There are many cases, however, in which even a false assertion of an opinion will amount to a fraud, the reason being that, under the circumstances, the other party has a right to rely upon what is stated or represented. Thus, the llability may arise where one has or assumes to have knowledge upon a subject of which the other is ignorant, and knowingly makes false statements, on which the other relles. Where parties possess special learning or knowledge on the subject with respect to which their opinions are given, such opinions are capable of approximating to the truth. And for a false statement of them, then deception is designed and injury has followed from rellance on the opintons, an action will 11e. Gordon v. Butler, 105 U.S. 553: Robbins v. Barton, 50 Kan. 120, $31 \mathrm{Pac}$. 686; Eaton v. Winnie, 20 M1ch. 156: Hicks v. Stevens, 121 I11. 186, 11 N.E. 241; Cooley, Torts, 483. Take the facts in the case at bar. The plaintiff, an illiterate man, badly Infured in an accident, and physically a wreck, consulted with the physictan and surgeon in charge of a medical and surgical institute or hospital as to his condition and the probability of a recovery. After an examination by the surgeons, he was positively assured, if he told the truth as to what was sald (and the jury found that he did), that he could be cured, and by treatment at that institute could and would be made sound and well. Considering the circumstances, and the relations of the parties, there was something more in defendants" statements than the mere expression of his opinion upon a matter of conjecture and uncertainty. It amounted to a representation that plaint1ff"s physlcal condition was such as to insure a complete recovery. The doctor, especlally trained in the art of healing, having supertor learning and knowledge, assured plaintlff that he could be restored to health. That the plaintiff believed him is easily imagined; for a much stronger and more learned man would have readily belleved the same thing. The doctor, with his sk111 and ability, should be able to approximate to the truth when giving his opinion as to what can be done with injuries of one year's standing, and he should always be able to speak with certainty before he undertakes to assert positively that a cure can be effected. If he cannot speak with certainty, let him express a doubt. If he speaks without any knowledge of the truth or falsity of a statement that he can cure, and does not belleve the statement true, or if he has no knowledge of the truth or falsity of such a statement, but represents it as true, of his own knowledge, it is to be inferred that he intended to deceive. The deception being designed in elther case, and injury having followed from reliance upon the statements, an action for decelt will 11 .

The evidence in this case was sufficient to warrant the jury in finding that plaintiff had sustained a facture at the base of the skull, and that his infuries were incurable; that, after examination, defendant Lawrence stated and represented that the plaintiff could and would be restored to health by treatment: and that he made such statements and representations 
for the purpose of inducing plaintiff to pay over the sum of $\$ 500$ to himself, or to the institute, or both. There was evidence from which the jury could find that he made these statements and representations without knowing whether they were false or true, not belleving they were true, and also that he made them without knowing their truth or falsity, but represerting them to be true, of his own knowledge. There was also evidence from which the fury could have found that the physictans and surgeons who made the examination at the Institute (Lawrence and another) knew that plaintiff had sustained a basal fracture of the skull, and that he could not recover his health. The evidence was abundant in support of the verdict.

Counsel makes the point that, as to defendant Lawrence, the action should have been dismissed, because he, as the president of the defendant institute, was simply acting for it as its agent. We are not aware of any rule of law whtch w111 excuse and absolve a person from the consequences of his own wrong because he happened to be the agent of another at the time of the perpetration of the wrong. It is also urged that the action cannot be maintalned, because of the written contract between the partles. There is nothing in this; for the action is not upon the contract, nor is it controlled by its terms and conditions. It is an action for fraud and decelt practiced upon the plaintiff, through and by means of which the contract was obtained. Order affirmed.

Reconsider Hawkins v. McGee, p. 97, supra. 
Norma11y promises are frobably not made with a present intent not to perform. Where they are, Section 473 of the Restatement of Contracts I provides that they constitute fraud. What of a misrepresentation that is made without knowledge of the falsity of the statement? What about a fallure to disclose something that you know which would affect the other party's evaluation of the deal? Consult the following two cases.

$$
\begin{gathered}
\text { Ham v. Hart } \\
58 \text { N.M. } 550,273 \text { P.厃d } 748 \text { (1954) }
\end{gathered}
$$

LUJAN, Justice.

During the summer of 1949 the defendant (appellee) had a water well drilled on the premises referred to in the complaint. She used water therefrom by means of a pump operated by electric current until November of that year when the electricity was turned off and never used again for approxi- .. . mately four years, or, unt11 it was sold to plaintiff in 1953. A $10 \mathrm{~g}$ was furnished defendant by the well driller in 1949 which indicated that it was 150 feet deep and would produce two gallons of water per minute at that time.

The plaintiff (appellant) instituted this action to recover damages alleged to have been sustained by reason of false and fraudulent representations made by the defendant to the plaintiff. The principal allegations in the complaint are in the following words:

"3. That during the negotiations, and in order to induce the plaintiff to purchase sald property, the defendant falsely and fraudulently represented to the plaintiff that the well located on the premises vas a good one, and that sald well would produce and pump not less than two gallons of water per minute; that the platntiff, relying on sald false and fraudulent representations of the defendant as to the condition of the well and as to the amount of water it would produce, agreed to and did purchase sald property: that subsequent to the time that the plaintiff purchased and paid for said property, he discovered that the well located on safd oremises was worthless and would not produce two gallons of watter per minute as represented by the defendant at all material times hereto.

"4. That the plaintiff would not have purchased the property of the defendant but for the false and fraudulent representations made to him by the defendant as to the condition and productivity of sald well.

"5. That because of the condition of the well on sald premises and Its fallure to be in the condition as represented by the defendant or to produce the water as represented by the defendant, it was necessary for the plaintiff, In order to procure the necessary supply of water on the premises, to obligate himself and expend the sum of $\$ 2,056.08$ to his damage in said sum. * *"

The cause was tried to the court, who at the conclusion of the entire case, on motion of defendant, dismissed plaintiff's complaint and he appeals. The parties 111 be referred to as they appeared in the district court.

[1] According to the record, there is abundant testimony to show that the defendant on three different occasions represented to plaintiff that the well in question had ample water capable to producing not 
less than two gallons of water per minute, when in fact it only produced one-half gallon per minute at the time the property was delivered to plaintiff; and that he relled upon sald representations.

It is insisted that the trial court committed error in making the following finding of fact and conclusion of law:

"Finding No. 14. That the defendant was motivated by neither bad falth nor dishonesty in her statements to the plaintiff."

"Conclusion No. 4. That the facts upon which this case is brought are consistent with honesty on the part of the defendant and that the presumption of honesty should preva11."

$[2,3]$ Whether the defendant acted honestly and in good faith is immaterial. The culpability which stamps statements as a fraud is in the assertion of that to be true which is not true, although belleved to be true, when made to be relled upon and which are relied upon to the injury of the party misled. Becker v. Mckinnie, $106 \mathrm{Kan} .426,186 \mathrm{P}, 496$ : Aldrich v. Scribner, $154 \mathrm{M1ch}$. 23, 117 N.W. 581, 18 L.R.A., N.S., 379, Rosenberg v. Cyrowsk1, 227 Mich. 508, 198 N.W. 905: Romine v. Thayer, 74 Ind. App.536, 128 N.E. 456 ; Joyce v. McCord, 123 Ark. 492, 185 S.W. 775; Laney-Payne Tarm Loan Co. v. Greenhaw, 177 Ark. 589, 9 S.W.2d 19, 73 A.L.R. 1117.

In 1 Story, Equity Jurisprudence, 14th Edition, sec. 272, Justice Story uses th1s language:

'Whether the party thus misrepresenting a material fact knew it to be false, or made the assertion without knowing whether It were true or false, is wholly immaterial: for the affirmation of what one does not know or belleve to be true is equally in morals and law as unjustifiable as the affirmation of what is known to be positively false. And even if the party innocently misrepresents a material fact by mistake, it is eoually conclusive; for It operates as a surprise and imposition upon the other party."

The statements as to the number of gallons the well would produce were material as a positive assertion of fact, affording a decisive consideration on plaintiff's willingness to contract. : He relled upon the1r truth and accuracy.

[4] We held in Jones v. Frledman, 57 N.M. 361, 258 P.2d 1113, that 1rrespective of the good falth with which a misrepresentation of material fact is made, if it is justiflably relied on by one seeking rescission of the contract, such rescission should be allowed, and we reaffirm that holding.

And in Bennett v. Finley, 54 M.M. 139, 215 P.2d 1013, 1015, we said:

"The representation was material in its bearing on deferáant's willingness to contract. If untrue, whether made innocently or with fraudulent intent, it was actionable, when relied upon by defendant, as the trial court found it was." 
For other cases holding to the same effect, see Wilson v. Robinson, 21 N.M. 422, 155 P. 732, Ann.Cas. 1918C, 49: Bel1 v. Kyle, 27 N.M. 9, 192 P. 512; and Thrams v. Block, 43 N.M. 117,86 P.2d 938.

The Jones and Bennett cases, as well as those holding to the same effect, were in equity, but we can see no difference in the principle Involved in an action at law for damages and a sutt in equity for rescission. Trust Company of Norfolk v. Fletcher, 152 Va. 868,148 S.E. 785, 73 A.L.R. 1111.

It is true that the weight of authority in actions at law for fraudulent misrepresentations require proof of knowledge. However, a strong minority follow the equity view that good falth is immaterlal and we belleve this view the better one and here adopt it.

Other errors are assigned and argued, but no additional question need be decided in view of the disposition we must make of the question fust discussed.

For the reasons stated the fudgment vill be reversed and the cause remanded for further proceedings in conformlty herewith.

It is so ordered.

Swinton v. Whitingville Sav. Bank

311 Mass. $677,42 \mathrm{~N} . \mathrm{E} .2 \mathrm{~d} 808$

(1942)

QUA, Justice.

The declaration alleges that on or about September 12,1938 , the defendant sold the plaintiff a house in Newton to be occupled by the plaintiff and his family as a dwelling: that at the time of the sale the house "was infested with termites, an insect that is most dangerous and destructive to buildings": that the defendant knew the house was so infested; that the plaintiff could not readily observe this condition upon inspection: that "knowing the internal destruction that these insects were creating in said house", the defendant falsely and fraudulently concealed from the plaintiff its true

condition: that the plaintiff at the time of his purchase had no knowledge of the termites, exercised due care thereafter, and learned of them August 30, 1940: and that, because of the destruction that was being done and the dangerous condition that was being created by the termites, the plaintiff was put to great expense for repalrs and for the installation of termite control in order to prevent the loss and destruction of said house.

[1] There is no allegation of any false statement or representation, or of the uttering of a half truth which may be tantamount to a falsehood. There is no intimation that the defendant by any means prevented the plaintiff from acquiring information as to the condition of the house. There is nothing to show any fiduclary relation between the parties, or that the plaintiff stood in a position of confidence toward or dependence upon the defendant. So far as appears the parties made a business deal at arm ${ }^{\prime} \mathrm{s}$ length. The charge $1 \mathrm{~s}$ concealment and nothing more: and it is concealment in the simple sense of mere fallure to reveal, with nothing to show any pecullar duty to speak. The characterization of the concealment as false and fraudulent of course adds rothing in the absence of further allegations of fact. Province Securities Corp. v. Maryland Casualty Co., 269 Mass. 75, 92, 168 S.E. 252. 
[2] If this defendant is 11able on this declaration every seller is liable who fails to disclose any nonapparent defect known to hin in the subject of the sale which materially reduces ito value and which the buyer fails to discover. Simllarly it would seem that every buyer would be liable who falls to disclose any nonapparent virtue known to him in the subject of the purchase which materially enhances 1 ts ralue and of which the seller is $1 \mathrm{~g}-$ norant. See Goodwin v. Agassiz, 283 Mass. 358, 186 N.E. 659. The 1aw has not yet, we believe, reached the point of Imposing upon the frallties of human nature a standard so idealistic as this. That the particular case here stated by the plaintiff possesses a certain appeal to the moral sense is scarcely to be denied. Probably the reason is to be found in the facts that the Infestation of buildings by termites has not been common in Massachusetts and constitutes a concealed risk against which buyers are off their guzrd. But the law cannot provide spectal rules for termites and can hardly attempt to determine liabllity according to the varying probabilities of the existence and discovery of different possible defects in the subjects of trade. The rule of nonllablilty for bare nondisclosure has been stated and followed by this court in Matthews v. B11ss, 22 P1ck. 48, 52, 53; Potts v. Chapin, 133 Mass, 276: Van Houten v. Morse, 162 Mass. 414, 38 N.E. 705, 26 L.R.A. 430, 44 Am.St.Rep. 373: Phinney v. Frledman, 224 Mass. 531, 533, 113 N.E. 285; Windram Mfg. Co. v. Boston Blacking Co., 239 Mass. 123, 126, 131 N.E. 454, 17 A.L.R. 669; Wellington v. Rugg, 243 Mass. 30, 35, 36, 136 N.E. 831, and Brockton 01ympla Realty Co. v. Lee, $266 \mathrm{Mas6}, 550,561,165$ N.E. 873. It is adopted in the American Law Institute's Restatement of Torts, . 6551. See Williston on Contracts, Rev.Ed., 8S 1497, 1498, 1499.

[3] The order sustaining the demurrer is affirmed, and fudgment is to be entered for the defendant. Kelflklan v. Star Brewlng Co., 303 Mass. 53, $55-63,20$ N.E.2d 465 .

So ordered.

What interest is the law protecting under these cases of misrepresentation? Is it the same as that protected by the law of contracts? What should the damages be? For example, consider the following hypot'etical:

Bob Buyer purchases a house from Sam Seller upon the misrepresentation that it has a dry cellar. In fact, the cellar is often wet. Buyer pays $\$ 20,000$ for the house. The house, with the wet cellar, w111 bring $\$ 18,000$ on the market if the condition of the cellar is known. If the house had a dry cellar, it would be worth $\$ 23,000$. It w111 take $\$ 5,000$ to repair the cellar so that it is dry.

In a sence at least, Buyer is out only $\$ 2,000$, the difference between what he pald and what the house was worth. On the other hand, it can be argued that he was damaged to the extent of $\$ 3,000$ (the difference between what he pald and what the house would have been worth had the cellar been as represented), or that his damage is $\$ 5,000$ (the amount necessary to make the house as it was represented). What is the proper measure of damages?

Consult Section 2-714 of the Uniform Commerclal Code. What would be the measure of damages if the Code applied? Consult also the following case. 
RICE V. PRICE

Supreme Judicla1 Court of Massachusetts, 1960. 340 Mass. 502, 164 N.E. 2 d 891.

[Defendant Price, a reglstered englneer and a graduate of a technical inatitute, controlled two corporations which manufactured and sold an electric steamless heater which he had designed. Price approached Baldwin, a ceramics salesman, and Rice, an insurance agent, in an attempt to induce them to undertake the distribution of the heater. He made varfous representations to them as to the efficlency of the heater, the novelty of the design and the electrically heated fluld used, his application for a patent, the cost of operation, and similar matters, ail of which were found to be false, and known to Prlce to be false when made. In rellance upon these representations, Baldwin and Rice organized the Baldwin-Rice corporation, which entered Into a contract with defendant's corporation, under which 1 t was to act as the sole distributor of the heater for a year, with the right of renewal at the explration of that time. Because of the matters misrepresented, the heater falled to se11, and the Baldwin-Rice company was forced out of business. The trial court referred the case to an auditor, who made findings of the plaintiffs" damages. Defendants moved to exclude these findings, and their bill of exceptions presented the question whether the fudge properly dented this totion, and a motion for a new trial.]

CUTTER, JUSTICE. * * * Baldwin resigned his former position about May 1 , 1955, and during the forty-elght weeks of his work for Baldwin-Rice recelved $\$ 3,840$ less than he would have earned in his former occupation exclusive of certain allowances for life Insurance premiums. He made a loan to, and paid debes of Baldwin-Rice for which he never was repald a balance of $\$ 2,693.23$. Rice's loss of income, as a result of becoming an employee of Baldwin-Rice, was $\$ 2,200$. He pald certain corporate loans and debts of which a "balance of $\$ 1,967.23$ was never [re]pald to hIm." Baldwin and Rice each Invested $\$ 1,000$ in purchasing stock in Baldwin-RIce, whlch, the auditor found, sustained a loss of $\$ 28,871.67$ (excluding certain sums owed to Baldwin and Rice).

The trial judge made findings (a) for Baldwin of $\$ 7,530.23$ against Price and in the same amount against Acme; (b) for Rice of $\$ 5,167.23$ against Price and In the same amount ageinst Acme: and (c) of $\$ 28,871.67$ for Baldwin-Rice against Price and in the same amount agalnst Lincoln Park.

There was ample evidence that Price made misrepresentations of material facts, susceptible of actual knowledpe, in order to induce the platntiffs to undertake the distribution of the heaters and that the plaintiffs relied upon these misrepresentations and suffered damages as a consequence. The defendants' principal contentions are that no recoverable damages have been shown as against any of the defendants and that the wrong measure of damages has been applied. It is further contended that Baldwin-Rice cannot recover at all against Lincoln Park or Price.

1. The trlal fudge stated, as the applicable measure of damages in deceit, "the difference in actual value between that which the plaintiff [s] in fact got and that which they would have recelved if the representations had been true." He in effect adopted the auditor's findings on damages. Upon the auditor's findings, Including the finding that Baldwin-Rice "went out of business *** because *** [the] steamless heaters did not possess the *** 
attributes represented * * $*$ by Acme and Price," the trial judge was warranted in concluding thist the whole business disaster and all the losses were caused by the fallure of the heaters to come up to the standards stated in the representations.

The Massachusetts decisions, in awarding damages in actions of deceit, have followed, at least in approprlate cases, the "benefit of the bargain" rule. Under this rule the plaintiff is entitled to recover the difference between the value of what he has recelved and the actual value of what he would have recelved if the representations had been true.[citations omitted.] This rule affords a recovery in decelt closely resembling that for breach of warranty. [citation omitted.]

The misrepresentations might reasonably have caused the plaintiffs to believe that the heaters were unique. The trial judge thus could have concluded that the defendants should have foreseen (a) that, relying on the misrepresentations, the individual plaintiffs would leave their former employments, make loans to and investments in a business or corporation to be formed, and lose those investments, and (b) that without such a unique heater having the represented characteristics, Baldwin-Rice would incur substantial losses, in competition with equally good established heaters.

Doubtless, as was sald in Thomson v. Pentecost, 206 Mass. 505, 512-513, 92 N.E. 1021; Id., 210 Mass. 223, 227, 96 N.E. 335, the individual plaintiffs would have been "content, if the defendant[s'] representations were true, to run the risk of undertaking this $* * *$ [distributorship] and abandoning their former occupations * * *. They are indemnified if these representations are made good" and if they recover under the benefit of the bargain rule "the difference between the actual value of this new employment $* *$ * and what that value would have been if the defendant [ $\left.s^{\circ}\right]$ representations had been true." [Citation omitted.]

The plaintiffs' just complaint is that, because of the misrepresentations, the hazards of the distributorship were vastly greater than the plaintiffs had reason to belleve them to be. In the circumstances, the damages awarded conceivably could be fitted into the concepts of the benefit of the bargain rule, on the theory that the distributorship and heaters recelved by the plaintiffs were worth less than represented by at least the amount of the losses caused by the misrepresentation. The trial judge, however, despite his statement of the benefit of the bargain rule of damages, has based the damages awarded very directly on the losses in fact suffered. There were no express findings about (a) what the value of the distributorship would have been if the representations had been true and (b) Its value in the light of the falsity of the representations, which might be a negative value in view of the losses and liabilities likely to be incurred because the representations were false. Obviously in proving these values the plaintiffs would meet sertous difficulties, which would be only partly overcome by recognition [citation omitted] that the "amount of damages seldom can be proved with [mathematical] exactness" and that much "must be left to estinate and judgment, sometimes upon meager evidence." Such difficulties of proof, however, can hardly be permitted (under a rule of damages designed to be generous in comparison with the out of pocket rule, see footnote 4, supra) to relleve defendants of the responsibility for losses which their misrepresentations have caused. [Citation omitted.] Accordingly, we consider whether the Massachusetts rule of damages permits the award of damages in the amount of the losses in fact caused by the misrepresentations, where 
only such damages are sought and proved.

The benefit of the bargain rule has not been rigidly followed in this Commonwealth, and this court has suggested that the rule may be modified or supplemented to prevent injustice. [Citation omitted.]

As one text writer points out, "[f] ew courts have followed efther rule with entire consistency" and there have been "proposals * * * to introduce some flexibility into the measure of damages." Prosser, Torts (2d ed.) s 91, pp. 569-570.***

A possible reconciliation of the two rules (based on Selman v. Shirley, 161 Or. 582, 85 P.2d 384, 91 P.2d 312) is summarized in Prosser, Torts (2d ed.) 570: "1. If the defrauded party is content with the recovery of only the amount he has actually lost, his damages will always be measured under that rule. 2. If the fraudulent transaction also anounted to a varranty, he may recover for loss of the bargain, because a fraud accompanied by a broken promise should cost the wrongdoer as much as the breach of promise alone. 3 . Where *** the proof $* * *$ [is] so vague as to cast virtually no light upon the value of the property had it conformed to the representations, damages w111 be awarded equal to the loss sustained, and 4 . Where the damages under the benefit-of-bargain rule are proved with reasonable certainty, that rule wt11 be employed. In addition * * the plaintiff may recover for consequential damages, such as $* *$ * expenses to which he has been put, provided that they are regarded as "proximate" results of the misrepresentation."

Rules 1 and 3 tend to prevent the benefit of the bargain rule from operating to defeat a just recovery where misrepresentation has caused real damage but where values cannot easily be proved. All the elements of damage and loss allowed by the trial fudge could have been found to have been caused proximately by the misrepresentations within these rules. So far as applicable here, they seem to be consistent with, and to substantiate, the statements in those Massachusetts cases, already cited, which supplement the benefit of the bargain rule. Although it has been suggested that rigid application of the benefit of the bargain rule may remove "speculation attendant in attempting to ascertain what portion of [such a] loss is attributable to the fraud and what portion $* * *$ to bad management or other factors not connected with the fraud," [citation omitted] the trial judge's findings here establish that the losses of Baldwin-Rice were "direct results of the wrong." In adopting the auditor's findings, the fudge Implledly made simflar findings as to Baldwin's and Rice's losses. There was no error in the assessment of damages $* * *$

\section{Exceptions overruled.}

The following case in many ways sums un much of what has been touched upon so far. Why didn't the plaintiff win? Could the result have been any different if he relied upon misrepresentation? If the courthad applied the ... Uniform Commerclal Code sections on varrantles by analogy, would the result have been different? What do you think of the result?

Anderson v. Backlund

$$
159 \text { Minn. } 423,199 \text { N.W. } 90 \text { (1924) }
$$

WILSON, C. J. This is an action to recover on a promissory note. Plaintiff's cause of action is not in controversy. The defendant alleged a counter- 
claim. Defendant was a tenant on a 640-acre farm owned by plaintiff, and a written lease defined the terms of this tenancy. He alleges, however, that in the month of June the parties made a further oral agreement, for the purpose of more securely assuring plaintiff that he would recelve certain case rent acdruing in prior years, whereln defendant agreed to buy 100 head of cattle and bring upon the farm and consume good pasture thereon, and that plaintiff agreed to provide, keep, and maintain on the farm a well, watering equipment, and water ample and sufficient for the needs of such 100 head of cattle, as well as for 67 head of cattle then owned and kept on the farm by defendant, and that, relying upon such agreement, and being induced thereby, defendant purchased and placed on the farm 107 head of cattle; that plaintiff violated his agreement; that the water supply falled, and because thereof all the 174 head of cattle became wasted, thin and depreclated in value, and defendants were damaged in the sum of $\$ 2,500$.

The court directed a verdict for the plaintiff for the amount claimed in the complaint, and, from an order denying defendant's motion for a new trial, he has appealed.

Our first inquiry is as to whether the oral contract as alleged by defendant is in fact established by the proofs. The only evidence in support of this allegation is the testimony of the defendant, John Backlund, which is as follows:

"We11 Mr. Anderson drove on the place, come there the same as always, and asked how everything was and how we got along. I told him it began to look pretty blue for me, two years kind of light crop I sald, and it looked to me I can't make both ends meet; and $\mathrm{Mr}$. Anderson sald, 'Well now, John'--I remember the words, "why don't you get some more cattle on here and make good use of all that grass and make some money." 'Well,' I says, "some of my nelghbors tells me if I stock up too heavy In the pasture and there be a "short spel1" I w11l be short of water, and I will be up against $1 t$, and that is the reason I am walting for you." Well he said, 'Never mind the water, John. I will see there will be plenty of water, because it never falled in Minnesota yet;' and I say, 'All right, I got 1 t all arranged to get all the cattle I want from Long \& Hanson In Sloux City; all I have to do is to go to the phone and call them up, and the cattle be here in 2 or 3 days." And he sald, 'All right.' And then furthermore, Anderson always tole me 'I am good for my word.' "s

If this constitutes a contract, what were the terms? How was he to provide water? Was he to drill a well? If so, when? What was the significance of the words, "because it never falled in Minnesota yet"? This rather characterized the talk more as visiting or advice than a contract, and we are forced to the conclusion that the parties did not make a contract. There is a lack of mutual assent to the same proposition; and the language is entirely too Indefinite and general as to the usual elements of a contract. The minds of the parties never met upon the essential terms. Contracts must be certain in terms, and not so indefinite and illusory as to make it impossible to say fust what is promised. The proof in this respect is insufficient. Because of such insufficlency the counterclaim falls, and the learned trial court was right in directing a verdict.

It becomes unnecessary to discuss the assignment of error relating to the rulings of the court in excluding testimony offered in support of the measure of damages.

Order affirmed. 
Does the right of action that the average consumer may have for breach of warranty or for misrepresentation really help him much? The cost of a law sult is prohibitive in many cases. How do you force a recalcitrant car dealer to repair your new car under a warranty? How do you get out of a deal, or get your money back, from the itinerant retaller who has bilked you? There is some government control of dishonest merchants. The Federal Trade Commission Act, and similar state acts in some jurisdictions, prohibits "unfair and deceptive trade practices," but enforcement is sometimes painfully slow and ineffective.

The National Consumer Law Center at Boston College Law School has drafted the "National Consumer Act". Initially, this was in response to the Uniform Consumer Credit Act that was drafted, and is being promoted, by the National Conference of Commisstoners on Uniform State Laws. The UCCC is designed as a "uniform act" and, like the Unfform Commerclal Code, is being proposed In all state leglslatures. The UCCC deals only with consumer credit, but the NCA goes far beyond. Consider the following sections which deal with deceptive practices. Note carefully the manner in which the Act is to be enforced. Is governmental intervention a necessary concommitant to the type of commerce that we have in this country? Is there st111 a necessity for private remedies? Is Contract Law as $1 t$ is presented by the typical textbook or law school course dead, or at least entering 1 ts dotage?

PART 4

CRTMINAL PENALTIES

Section 5.401 WILLFUL VIOLATIONS: MISDEMEANOR

A person who willfully engages in any conduct or practice in violation of this Act is guilty of a misdemeanor and upon conviction may be [sentenced to a fine not exceeding $\$ 2000$ ].

\section{Section 5.402. DISCLOSURE VIOLATIONS}

A person who wlllfully violates the provisions on disclosure (Part 3 ) of the Article on Consumer Credit Transactions (Article 2) is guilty of a [misden aror] and upon conviction may be sentenced to pay a fine not exceeding $\$ 5000$, or to Imprisonment not exceeding one year, or both.

\section{Coment}

These two sections provide criminal penalties for violation of this Act. The first sectfon provides a misdemeanor for willful violation of this statute. The second section provides a penalty for violation for disclosure provisions which is identical to that provided in the Federal TRuth-In-Lending Act. Under the second section, local state enforcing officers may actually enforce criminal violations of the Federal statute, since they constitute a violation of this statute. 
ARTICLE 6

ADMINISTRATION

PART I

POWERS AND FUNCTIONS OF ADMINISTRATOR

Section 6.101. SHORT TITLE

This article shall be known and may be clted as National Consumer Act -Administration

Section 6.102. APPLICABILITY

Th1s Article applies to a merchant whose activities are directed toward or affect consumers in this State and to a person who takes assignments of and undertakes direct collection of payments from or enforcement of rights against consumers, to a person engaged in the business of debt collection or in the business of reporting agencles.

Section 6.103. ADMINISTRATOR

$$
\text { Administrator means [ ]. }
$$

COMMENT

Effective and energetic administration is vital to the Act. Since each state has a different structure in its executive branch, the Act does not specifically identify the Administrator. However, the draftsmen are concerned that traditional regulatory agencies have often become the servants rather than the policemen of the industries they have been charged with supervising. This has been particularly true of 11censing agencies. Therefore the draftsmen recommend that where possible the administering agency be a new office, directly responsible to the Governor, with no duttes other than administration of this Act and other consumer protection legislation. We discourage extending the responsibilities of Banking, Insurance and other existing departmonts to include administration of this act.

Section 6.104. POWERS OF ADMINISTPATOR: DUTY TO REPORT

(1) In addition to other powers granted by this Act, the Administrator within the 1imitations provided by law sha1l:

(a) Peceive and act on complaints, take action designed to obtain voluntary comoliance with this Act, or commence proceedings on his own inftiative:

(b) Counsel persons and groups on their rights and duties under this Act:

(c) Establish proprams for the education of consumers with respect to consumer practices and problems: 
(d) Make studies approprlate to effectuate the purposes and policies of this Act and make the results avallable to the public:

(e) Hold such public or private hearings as he deems necessary or proper to effectuate the purposes and policies of this Act:

(f) Subpoena witnesses, compel their attendance, adduce evidence and require the production of such relevant matter as he deems necessary or proper to effectuate the purposes and policles of this Act:

(g) Adopt, amend, and repeal rules and regulations to carry out the purposes and Dolicles of this Act, to prevent circumvention or evasion thereof, or to facilitate compllance therewith. These rules and regulations may contain such classifications, differentiations or other provisions and may provide for such adjustments or exceptions as in the fudgment of the Administrator are necessary or proper to effectuate the purposes of this Act.

(h) Maintain such offices as he deems necessary within this State: and

(1) Appoint such attorneys, hearing examiners, clerks, and other employees and agents as in the fudgment of the Administrator are reasonably necessary to perform his functions under this Act and $f 1 x$ their compensation, and authorize attorneys aboointed under this section to anpear for and represent the Administrator in court.

(2) The Administrator shall report annually [on or before January 1] to the [Governor and/or Leg1slature] on the operation of his office, on practices in consumer transactions, on the use of consumer credit in the State, on problems attending the collection of debts, on reporting agencies, on the problems of persons of limited means in consumer transactions, and on the operation of this Act. For the purpose of making the report, the Administrator is authorized to conduct research and make approprlate studies. The report shall include:

(a) a description of the examination and investigation procedures and policles of his office:

(b) a statement of policies followed in deciding whether to investigate or examine the offices of persons subject to this Act:

(c) a statement of policles followed in deciding whether to bring any action authorized under this Act: 
(d) a statement of the number and percentages of classes of merchants registered under this Act which are per:lodically investigated or examined:

(e) a statement of the types of consumer problems of both consumers and merchants which have come to his attention and the disposition of them under existing law;

(f) a complete survey of the costs of various types of credit avallable in the State to the consumer and the cost to the rreditor of each such type of credit, with a comparison of each to the prevalling rates of charges for credit, both the maximums permitted by law and the amounts actually charged if below the maximums:

(g) a statement reviewing creditor profits from credit operations:

(h) a statement of sales and advertising practices tending to promote debt in such a way as to jeopardize the financial security of consumers.

(1) a list of all persons who have challenged any action of the Administrator in a public hearing or in a fudicial proceeding and a brief description of the facts in each case;

(f) a list of all persons against whom complaints have been filed or investigations commenced along with a brief de. scription of the facts of each case and the action taken in each, if such case has not been resolved within three months from the filing of the complaint or the commencement of the investigation, whichever is earlier.

(k) such recommendations for modifications or additions to this Act as in the experience and fudgment of the Administrator are necessary; and

(1) such other statements as are necessary or proper to achieve the purposes or policies of this section or to effectuate the purposes or policies of this Act.

(3) Within 10 days following its submission to the [Governor and/or Legislature], the Administrator shall publish and make avallable to the communications media and other interested partles sufflclent coples of his report.

\section{Comment}

The Administrator is required under this section and other sections of this Article to perform a broad range of duties. To carry out his functions he is given ample general powers here and some specific powers elsewhere. The granting of spectific 
powers anywhere in this Article is not intended to diminish In any way the general grant of powers which should be construed broadly to achieve the purposes of this Act. The Administrator is the watchdog for the consuming public and his powers must of necessity be equal to the scope of his task.

\section{Section 6.105. ADMINISTRATIVE POWERS WITH RESPECT TO SUPERVISED} FINANCIAL ORGANIZATIONS

(1) Al1 powers and dutles of the Administrator under this Act shal1 be exercised by him with respect to a supervised financlal organization.

(2) If the Administrator receives a complaint or other information concerning non-compllance with this Act by a sunervised financlal organization, he shall inform the official or agency having supervisory authortty over the organization concerned. The Administrator may request information about supervised financlal organizations from the officials or agencies supervising them.

(3) The Administrator and any offictal or agency of this State having supervisory authorfty over a supervised financlal organization are authorized and directed to consult and assist one another in maintaining compliance with this Act. They may folntly pursue investigations, prosecute sults, and take other offictal action, as they deem appropriate, if either of them otherwise is empowered to take the action.

\section{Comment}

Although "supervised financlal organizations" are subject to supervision by an official or agency other than the Administrator, the purposes for such supervision differ from that of administration of this Act. There is, therefore, no reason why all of the powers of the Administrator should not apply to all whose conduct is regulated under this Act. The administration of this Act can best be accompilshed by a single agency, and division of responsibility w111 tend to promote uneven and unequal enforcement.

\section{Section 6.106. INVESTIGATORY POWERS}

(1) If the Administrator has reason to belleve that a person has engaged in an act which is subject to action by the Administrator, he may make an investigation to determine if the act has been commltted and, to the extent necossary for this purpose, may administer oaths or affirmations, and, upon his own motion or upon reauest of any party, may subpoena witnesses, compel their attendance, adduce evidence, and require the production of any matter which is relevant to the investigation, including the existence, description, nature, custody, condition, and location of any books, documents, or other tanglble things, and the Identity and location of persons having knowledge of relevant facts, or any other matter reasonably calculated to lead to the discovery of admisstble evidence, and he shall have the right of

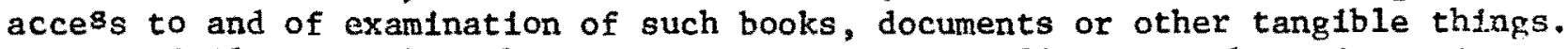
In any clvil action brought by the Administrator following such an IvvestigatIon, the Administrator may recover his costs of making the investigation If he prevalls in the action. 
(2) If 10 or more consumers file a signed complaint with the Administrator alleging that a person has engaged in an act which is subject to action by the Administrator, he shall immediately commence an investigation pursuant to subsection (1) of this section.

(3) If the perscn's records are located outside this state, the person at his option shall efther rke them avallable to the Administrator at a convenlent location within this state or pay the recsonable and necessary expenses for the Administrator or his representative to examine them at the place where they are maintained. The Administrator may designate representative, Including comparable officlals of the State in which the records are located, to inspect them on his behalf.

(4) The Administrator may by regulation require that certain records be kept within this State and that he be notifled of their location.

(5) Upon fallure without lawful excuse to obey a subpoena or to give testimony and upon reasonable notice to all persons affected thereby, the Adminietrator may apply to [ ] court for an order compelling compliance.

Comment

The UCCC permitted the Administrator to commence an investigation only if he had probable cause to believe that a violation had occurred. There is no reason given by the draftsmen of the UCCC, nor is any apparent, for subjecting the Administrator in an administrative proceeding to the harsh standards of the criminal law. Th1s section permits the Administrator $1 \mathrm{n}$ his discretion to make whatever investigations are needed for enforcement. Ample protection is provided for an overzealous administrator in the political and governmental process, and the history of administrative agencjes at any governmental level does not support an argument that they harass or too zealously over-see the industry they regulate. The administrator is also required to make such investigations where he recelves a complaint signed by at least ten members of the consuming public.

Section 6.107. APPLICATION OF [ADMINISTRATIVE PROCEDURE ACT] [PART ON ADMINISTRATIVE PROCEDURE AND JUDICIAL REVIEW]

Except as otherwise provided, the [State administrative procedure act] [Part on Administrative Procedure and Judiclal Review (Part 4) of this Art1cle] applies to and governs all administrative action taken by the Admintstrator pursuant to this Act.

Section 6.108. ADMINISTRATIVE ENFORCEMENT ORDERS

(1) After notfce the Administrator may order a person subfect to this Act or a person acting in his behalf to cease and desist from engaging in violations of thls Act or from engaging in unfair, deceptive, fraudulent or unconscionable conduct. If, after the order is made, a written request for a hearing is filed and no hearing is held within 30 days thereafter, the order is rescinded. A respondent aggrieved by an order of the Administrator may obtain judiclal review of the order and the Administrator may obtain an order of the court for enforcement of 1 ts order in the [ ] court. The proceeding for review or enforcement is initlated by filing a petition in 
the court. Coples of the petition shall be served upon all parties of record.

(2) Within 30 days after service of the petition for review upon the Administrator, or within any further time the court may allow, the Administrator shall transmit to the court the original or a certified copy of the entire record upon which the order is based, Including any transcript of testimony, which need not be printed. By stipulation of all parties to the review proceeding, the record may be shortened. After hearing, the court may:

(a) reverse or modify the order if the findings of fact of the Administrator are clearly erroneous in view of the evidence on the whole record;

(b) grant any temporary relief or restraining order it deems just, and:

(c) enter an order enforcing, modifying, and enforcing as modified, or setting aside in whole or in part the ordar of the Administrator, or remanding the case to the Administrator for further proceedings.

(3) An objection not urged at the hearing shall not be considered by the court unless the fallure to urge the objection is excused for good cause shown. A party may move the court to remand the case to the Administrator In the interest of fustice for the purpose of adducing additional specified and material evidence and seeking findings thereon upon good cause shown for the fallure to adduce this evidence before the Administrator.

(4) The furisdiction of the court shall be exclusive and Its final judgment or decree shall be subject to review by the [ ] court in the same manner and form and with the same effect as in appeals from a final judgment or decree in a [spectal proceeding]. The Administrator s copy of the testimony shall be avallable at reasonable times to all parties for examination without cost.

(5) A proceeding for review under this section must be inftiated within 30 days after a copy of the order of the Administrator is received. If no proceeding is so inftiated, the order is a lawfully made final order.

Section 6.109. UNCONSCIONABLE CONDUCT

The Administrator shall promulgate regulations declaring specific practices in consumer transactions or collection of debts arising therefrom to be unconscionable and prohibiting the use thereof. In promulgating such regulations, the Administrator shall consider, among other things:

(1) The degree to which the practice unfairly takes advantage of the lack of knowledge, abllity, experience, or capacity of consumers;

(2) Knowledge by those engaging in the practice of the inability of consumers to receive benefits properly. anticlpated from the goods or services involved: 
(3) Gross disparity between the price of goods or services and their value as measured. by the price at which similar goods or services are readily obtainable by other consumers, or by other tests of true value:

(4) The fact that the practice may enable merchants to take advantage of the inability of consumers reasonably to protect their interests by reason of physical or mental infirmities, illiteracy or inability to understand the language of the agreement, ignorance or lack of education or similar factors:

(5) The degree to which terms of the transaction require consumers to waive legal rights:

(6) The degree to which terms of the transaction require consumers to jeopardize money or property beyond the money or property immediately at Issue in the transaction:

(7) The degree to which the natural effect of the practice is to cause or ald in causing consumers to misunderstand the true nature of the transaction or their rights and duties thereunder.

(8) The extent or degree to which the writing purporting to evidence the obligation of the consumer in the transaction contains terms or provisions or authorizes practices prohibited by law; and

(9) Definitions of unconscionability in statutes, regulations, rulings and decisions of leglslative, administrative or fudicial bodies in this state or elsewhere.

\section{Comment}

This section gives the Administrator the authority to issue regulations which would outlaw certain types of practices where an unconsclonable advantage is taken of the consumer. Moreover, under Article 5, the trier of fact in a consumer's remedy civil action is directed to consider the action of the Administrator and the criteria established by this section in determining unconscionability. The criteria outlined in this section for the Administrator to consider reflect the most common factors that soclety would recognize as constituting probable unfairness in consumer transactioas.

\section{Section 6.110. TFMPORARY RELIEF: INJUNCTIONS}

(1) The Administrator or any consumer may bring a civil action to restrain a person from violating this act or the rules and regulations pronulgated pursuant thereto, or to restrain a merchant or a person acting on behalf of a merchant from engaging in unfalr, deceptive, fraudulent, or unconscionable conduct.

(2) The Administrator or consumer may seek a temporary restraining order without written or oral notice to the adverse party or his attorney. If the court finds that there is reasonable cause to believe that the respondent is engaged in the conduct sought to be restrained, it may grant a temporary restraining order or any temporary relief it deems appropriate. A 
temporary restraining order granted without notice shall expire by its terms within a stated time after entry, not to exceed 30 days, as the court fixes, unless within this time it is extended by the court, or unless the party against whom the order is directed consents that it may be extended for a longer period. When a temporary restraining order is granted without notice, the motion for a preliminary injunction shall be set down for a hearing at the earliest possible time. On flve days notice to the party who obtained the temporary restraining order without notice, the adverse party may appear and move its dissolution or modification, and in this event the court shall proceed to hear and determine such motion as expeditiously as the ends of justice require.

Section 6.111. CLASS ACTIONS

(1) Either the Administrator, or any consumer affected by a violation of this act or of the rules and regulations promulgated pursuant thereto, or by an unfair, deceptive, fraudulent, or unconscionable practice may sue, on behalf of all fersons similarly situated, regardless of the amount $:$ : controversy, for the rellef to which such persons would be entitled under the provisions of this act. A privete party filing such an action must give frompt notice thereof to the Administrator, who shall be permitted, upon application within 30 days, to join as a party plaintiff. For purposes of apportionment of cost, the Administrator need not be a party to the action.

(2) The court shall permit the suit to be maintained on behalf iff all members of the represented class if:

(a) the class is so numerous that joinder of all members is impracticable:

(b) the questions of law and fact common to the class are substantially similar and predominate over the questions affecting individual members;

(c) the claims or defenses of the representative plaintiffs are typical of the claims or defenses of the class:

(d) If the Administrator is not a party plaintiff, the representative parties will fairly and adequately protect the irterests of the class.

(3) As soon as practicable after the commencement of a class action brought under this section, the court shall hold a preliminary hearing to determine whether it is to be so maintained. An order following such hearing may be conditional, and may be altered or amended before the deciston on the merits.

(4) If the action is to be permitted as a class action, the court shall direct the defendant to serve upon each member of the class the best posstble notice of the action, including individual notice to all members who can be identifled through reasonable effort, which states that: 
(a) the court will exclude him from the class if he so requests by a specified date:

(b) the fudgment, whether favorable or not, w111 include all members who do not request exclusion:

(c) any member who does not request exclusion, may, if he desires, enter an appearance through counsel.

(5) When appropriate (a) an action may be brought or maintained as a class action with respect to particular issues, or (b) a class may be divided into subclasses and each subclass treated as a class, and the provisicns of this Section shall then be construed and applied accordingly.

(6) A class action shall not be dismissed, settled, or compromised without the approval of the court and the best possible notice of the proposed dismissal, settlement, or compromise shall be given to all members of the class in such manner as the court directs, and the court shall apportion all costs of notice between the Adninistrator and the defendant in such manner as it deems equitable and appropriate.

(7) The judgment In a class action shall describe those to whom the notice was directed and who have not requested exclusion, and those the court finds to be members of the class; the best possible notice of the judgment shall be given in such manner as the court directs to each person who received the original notice and has not requested exclusion; if the fudgment is for the plaintiff the court shall direct the defendant to reimburse the Administrator for all costs of notice.

(8) A plaintiff who yrevalls in a class action under this act shall be awarded a reasonable counsel fee, to be specified in the fudgment, which shall equal ten per cent of the gross judgment unless the court finds a different amount to be more equitable. A legal ald society or legal services program which represents a class shall be awarded a service fee in lieu of counsel fees, equal in amount to the counsel fee as measured by this subsection.

(9) The Administrator, whether or not a party to an action, shall bear the costs of notice except that he may recover such costs from the defendant as provided in subsections (6) and (7) of this section.

\section{Comment}

This section allows for genuine class actions to be commenced on behalf of consumers by either the Administrator or by a consumer. The JUCCC permits an extremely limited action and then only with respect to excess charges. Class actions are more needed in consumer transactions than almost anywhere else because the amount of the recovery will frequently be so small as to make it an exposive hardship for a single individual to pursue his legal rights. Under this section, costs of notice are borne by the Administrator, although he may recover these from a defendant who does not prevail, and attorney's fees are awarded to a successful plaintiff. 
Section 6.112. VENUE

The Administrator or consumer may bring actions or proceedings in a court In a county in which an act on which the action or proceeding is based occurred or in a county in which the defendant re: Ides or transacts business.

Section 6.113. DEBTORS" REMEDIES NOT AFFECTED

The grant of powers to the Administrator 1n this Article does not affect remedies avallable to consumers under this Act or under other principles of lav or equity.

ARTICLE 3

SALES PRACTICES

PART I

GENERAL PROVISIONS

Section 3.101. SHORT TITLE

This Article shall be known and may be clted as the Nat1onal Consumer Act -- Sales Pract1ces.

Section 3.102. SCOPE

Th is Article applies to unfalr and deceptive sales practices, warranties and advertising.

PART 2

UNFAIR AND DECEPTIVE TRADE PRACTICES

Section 3.201. UNLAWFUL SALES PRACTICES

(1) The following unfalr methods of competition and unfalr or deceptive acts or practlces undertaken by a merchant are hereby declared to be unlawful and prohtbited:

(a) Passing off goods or services as those of another;

(b) Causing 1ikelthood of confusion or of misunderstanding as to the source, sponsorship, approval, or certlfication of goods or services:

(c) Causing likelthood of confusion or of misunderstanding as to affiliation, connection, or association with, or certification by, another:

(d) Using deceptive representations or designations of geographic ortgin in connection with goods or services;

(e) Representing that goods or services have sponsorship, approval, characteristics, Ingredients, uses, benefits, or quantities that they 
do not have or that a person has a sponsorship, approval, status, affiliation, or connection that he does not have;

(f) Representing that soods are original or new if they are deterlorated, altered, reconditioned, reclatmed, used, or secondhand:

(g) Representing that goods or services are of a particular standard, quality, or grade, or that goods are of a particular style or model, if they are of another;

(h) Disparaging the goods, services, or business of another by false or misleading repregentation of fact;

(1) Advertising goods or services with intent not to sell them as advert1sed;

(j) Advert1sing goods or services with intent not to supply reasonably expectable public demand, unless the advertisement discloses a limitation of quantity;

(k) Making false or misleading statements of fact concerning reasons for, existence of, or amounts of price reductions;

(1) Representing that the consumer transaction confers or Involve? rights, remedies or obligations that it does not have or Involve or wh1ch. are prohibited by law;

(m) Representing that a part, replacement or repalr service is needed when it is not;

(n) Representing that the subfect of a consumer transaction has been supplied in accordance with a previous representation when it has not;

(o) Representing that the consumer w111 recelve a rebate discount or other economic benefit as an inducement for entering into a consumer transaction if the earning of the benefit is contingent on an event to occur subsequent to the consummation of the transaction.

(p) Causing 1ikelinood of confusion or of misunderstanding with respect to the authority of a salesman, representative or agent to negotiate the final terms of a trensaction with a consumer:

(q) Engaging in any other conduct which similarly creates a likelihood of confusion or of misunderstanding; or

(r) Engaging in any act or practice which is unfalr or deceptlve to the consumer.

Comment

1. The Uniform Consumer Cred1t Code contains no equivalent to Article 3 of this Act. Article 3 of the Credit 
Code deals with consumer loans which, under this act, are included in Article 2. By falling to provide protections to the consumer against unfair and deceptive trade practices, the draftsmen of the Credit Code eompletely 1gnored the fact that these practices often accompany credit transactions. Thus, the Credit Code is too limiting in its scope. Furthermore, since many credit transactions are in fact sales of goods, there is need to afford the consumer a additional warranty protection.

2. This Section contains an exhaustive 1ist of deceptive sales and trade practices. The list is not exclusive, and a consumer may establish in court other unfair and deceptive practices. The Administrator 1s also entitled to establish such practices by rule or regulation. Many of the prohibited practices are already prohibited under the Federal Trade Commission Act and under State Deceptive Practices Acts. What this Article does is provide the consumer with a remedy under State law.

(2) Without limiting the scope of subsection (1), an act or practice is a violation of this section, if:

(a) It is oppressive or other wise unconscionable in any respect:

or

(b) It falls to comply with lexisting state consumer protection statutes] the Federal Trade Commission Act, the FEderal Consumer Credit Protection Act, or other Federal Consumer Protection statutes.

\section{Comment}

This subsection makes "oppresstve and unconscionable" actions unfair and deceptive within this Article. It also incorporates by reference existing Federal and State laws for the protection of the consumer. These In addition to the obvious would include laws regulating weights and measures, quantity, labeling, quality of food stuffs and the like.

Section 3.202. RULES AND REGULATIONS

(1) It is the intent of the legislature that in construing Section 3.201 due consideration and great weight shall be given to the interpretatlons of the Federal Trade Commission and the Federal courts relating to Section 5(a) (1) of the Federal Trade Commission Act (15 U.S.C. 45 (a) (1), as from time to time amended.

(2) The [Administrator] may make rules and regulations interpreting the provisions of Section 3.201 of this Act. Such rules and regulations shalil not be inconsistent with the rules, regulations and decisions of the Federal Trade Commission and the federal courts in interpreting the provisions 
of Section 5(a) (1) of the Federal Trade Commission Act (15 U.S.C., 45(a) (1), as from time to time amended.

\section{Section 3.203. REMEDIES AND PENALTY}

In addition to any other remedy provided by 1 aw, a consumer who has been induced to participate in' a consumer transaction as a result of an act or practice undertaken by a merchant in violation of the provisions on unlawful sales practices (Section 3.201 ) shall be entitled to a recovery from the merchant in accordance with the provisions of section 5.304.

\section{Comment}

Rather than allow the consumer trouble damages, a remedy open to merchants under certain Federal statutes, this Act would give a consumer adversely affected by an unfair or deceptive practice the maximum civil penalty allowed under Article 5. This not only would deprive the offending merchant of his profit, but would constitute a monetary penalty.

PART 3

WARRANTIES AND ADVERTISING

\section{Section 3.301. DEFINITIONS: "WARRANTY;" "MERCHANTABLE"}

(1) "Warranty" means express and Implied warranties as defined in [Sections 313, 314, and 315 of Article 2 of the Uniform Commerclal Code] and expression or action of the merchant which assures or purports to assure the consumer, directly or indirectly, that the goods have described qualities or will perform in a described manner.

(2) "Merchantable" means, in addition to the qualitiss prescribed in [Section 314 of Article 2 of the Uniform Commercial Code], that the goods conform in all materlal respects to applicable state and Federal statutes and regulations establishing standards of quality and safety of goods, and, in the case of goods with mechanical, electrical or thermal compcnents, are in good working order and will operate properly in nornal usage for a reasonable period of time.

\section{Comment}

These definftions are intended to expand the warranty obligations of a seller of merchandise. They incorporate the definftions and concepts in the unfform commerclal code, but had additional concepts clarified the scope of the undertakings of sellers. The definition of "Merchantable" now includes complirnce with statutes designed to set standards for products sold or furnished to consumers. This could include the safety provisions for automobiles under the Federal Act, standards of grading for meat and food stuffs, useful life of products that are so dated, and the like. 
Section 3.302. DISCLATMER OF WARRANTIES AID REMEDIES

PROHIBITED.

Notwithstanding any other provisions of law, with respect to goods which are the subject of or are Intended to become the subject of a consumer transaction, no merchant shall:

(1) Exclude, modify or otherwise attempt to limit any warranty, express or 1mplied by law, including the warrantles of merchantability and fitness for particular purpose: or

(2) Exclude, modify or attempt to 1 Imit any remedy provided by law, including the measure of damages available, for a breach of warranty, express or Implied.

\section{Comment}

1. There are decisions of courts which hold that because Implied warrantles are created by law, the partis are not free to exclude or modify them. Of course, Section 2-316 of the Uniform Commerclal Code seems to hold othervise. Under this Section, a merchant may not disclaim either express or implied warranties. Actually, this changes the law only with respect to the implied warranty of merchantabllity, since a merchant need not make a warranty of fitness for a particular purpese or any express warranty. In short, he may still disclaim or avold those warranties simply by not making them. Howfver, if he does make them, then he should abide by them.

2. Another provision often appearing in boller plate forms is one which limits the remedy a consumer has even for breech of an express warranty. This Section prohibits any exclusion or modiflcation of the remedles the consumer has at law. Nothing, of course, prohibits a merchant from giving additional remedies, such as replacement or repairs. These, however, may not displace the other remedies. Already in a limitation of remedy for personal infury is unconscionable under Section 2-718 of the Uniform Commerclal Code, so this section is not as radical as it may first appear.

Section 3.303. VIOLATIONS

A violation of the provisions of Section 3.302 shall be subject to the provisions of Section 5.303.

SectIon 3.304. BREACH OF WARRANTY: PRIVITY ABOLISHED

Notwithstanding any provision of law, no action by a consumer for breach of warranty or for negligence with respect to goods subject to a consumer transaction shall fall because of a lack of PRIVITY between the consumer and the defendant. An action agalnst any person for breach of warranty or for negligence with respect to goods subfect to a consumer transaction shall not of Itself constitute a bar to the bringing of an action against another person. 


\section{Comment}

This Section is designed cleanly and succinctly to "topple the citadel of privity" once and for all.

\section{Section 3.305. FALSE, MISLEADING OR DECEPTIVE ADVERTISING}

No merchant sha11 advertise, print, display, publish, distribute or broadcast or cause to be advertised, printed, displayed, published, distributed or broadcast, in any manner any statement or representation with regard to the sale of goods or the extension of consumer credit including the rates, terms or conditions for the sale of such goods or the extension of such credit, which is false, misleading, or deceptive, or which omits to state material information that is necessary to make the statements therein not false, misleading or deceptive.

Section 3.306. REMEDIES AMD PENALTY

In addition to any other remedy provided by law, a consumer who has been induced to participate in a consumer transaction as a result of advertising in violation of Section 3.305 shall be entitled to a recovery from the merchant in accordance with the provisions of section 5.302.

\section{Comment}

Many states already have statutes similar to section 3.305. Often they are not as inclusive as this section. Such provisions began with the old "printer's Ink" statutes. The definition of "merchant" In Section 1.301 is broad enough to include not just the merchant for whom the advertisement is prepared, but also the agency who is responsible for violating the statute.

This Section does not and cannot replace the advertising restrictions of the Federal truth and lending Act. They are not subject to exemption by State action. That Act and the provisions of Regulation $Z$ are rather precise in the requirements for advertising terms of consumer credit. A violation of the Federal Act would now constitute a violation of this section and this Act as we11.

\section{ARTICLE 4}

INSURANCE

PART I

INSURANCE IN GENERAL

Section 4.101. SHORT TITLE

This Article shall be known and may be cited as National Consumer Act -- Insurance. 
Section 4.102: SCOPE; RELATION TO CREDIT INSURANCE ACT: APPLICABILITY TO PARTIES

(1) Except as provided in Subsection (2), this Article applies to Insurance provided or to be provided in relation to a consumer credit transaction.

(2) The provision on cancellation by a creditor (Section 4.304) applies to loans the primary purpose of which is the financing or insurance.

[(3) Th1s Article repeals the Credit Insurance Act.] 


\section{Unjust Enrichment, Quasi Contract, Contracts Implied in Law, Constructive Contracts and the Iike}

Contract law is the law of promises and can, perhaps shoul $i$, be restricted to situations where the parties voluntarily assume an obligation. Warranties, fraudulent misrepresentations and the like are on the border: not promissory, but akin to promises. Quasi contracts is something quite different and perhaps the most important fact to remember in dealing with this area of the law is that it has nothin. to do with contract law....n does it?

The material. that immediately follows is the introduction to a book entitled "Unjust Enrichment" by Professor Tohn Dawson. Aft.2n Professor Dawson's material is the first chante" of a muci older "ow. Quasi-Contract by Professor Willjam Keenor which was published in 7 ? The Keener work was the first attempt to organjze and systemitize t: area of the law.

This is a part of the law that is generally confusing to students, lawyers and even to law professors. Perhaps Professor rrw: w puts his finger on the reason: we look for rules where we should te concerned general guidelines.

\section{UNJUST ENRICHNENT \\ John P. Daws on}

\section{Introduction}

"A person who has been unjustly enriched at the expense of another is required to make restitution to that other."

"For this by nature is equitable, that no one be made richer through another's loss."

$\mathrm{T}$

HE FIRST of these two statements comprises

Section 1 of the American Law Institute Restatement of Restitution. The second comes from Pomponius, in the second century A.D. Of the two I prefer Pomponius. It is not merely that Pomponius is more elegant, for elegance is a minor virtue in a lawyer. Nor is it that Pomponius' maxim has had a long and immensely successful career. It is rather that he combines elegance with exactness. For his statement, both by the elements he includes and the form in which it is drawn, requires no warning to the reader that it is not intended to be a "rule" but merely "a general guide for the con- 
duct of the courts." It is quite true that in the eighteen hundred years intervening there have been many persons who have tried to make it a universal rule, but Pomponius should not be blamed for that. To any careful reader he expressed with great precision the relationship of his principle to any legal system at any time or place.

The Restatement differs from Pomponius in omitting any reference to "nature" (implying the law of nature). This will hardly be considered a fault in the Restatement. Whatever the views of its authors may be, it is unlikely that the Institute Council would have entered willingly into the ancient controversies on this subject and ascribed one of its black-letter propositions to the law of nature. It is only fair to Pomponius, however, to state that this loaded word may not be his at all, and may have come from some nameless Greek long after he was dead. ${ }^{1}$ The attribution to "equity" is essential for his analysis and seems authentic, not only as a reference that might have been made by a Roman lawyer in the second century A.D. but as a form of literary expression that is acceptable to us. For we have in Pomponius' statement, more clearly than in the Restatement, a general principle of justice, at a high though not the highest level of abstraction. It expresses both an aspiration and a standard for judgment. It has been quoted through the centuries because the aspiration lies deep in human nature and the standard is one we can use.

We can approach our general problem by invoking some rudimentary psychology. The statement of Pomponius, like Section 1 of the Restatement, suggests an element of causation; it implies a type of enrichment that is caused (and perhaps also measured) by another's loss. To the person who has suffered loss, the loss alone is a grievance. But if this loss can be located and identified in the gain received by another, the anguish caused by the loss will be felt as more than doubled. One can see this, for example, in the system developed by Karl Marx, who tapped an inexhaustible supply of resentment with the aid of his labor theory of value. Marx made 
it appear that the gains received by economic groups other than labor - particularly by owners of land and other capital assets - were unjustified by their contribution to the economic product and in the long run were taken from labor. The impact of the Marxian analysis can be in part attributed to the skill and ingenuity with which this idea was exploited by him and by his followers. But the same kind of argument can be used, with different premises, on other broad issues of social justice. When we come to the narrower issues arising in disputes between individuals, we often find it possible to trace much more directly the connection between losses incurred and gains received. Where the connection can be shown, a similar response can be expected, without any overtones whatever of social or economic reformism. The translation of loss by one individual into gain for another is felt as an aggravation, multiplying both factors in the equation.

When the problem is viewed more objectively, as a problem of corrective justice, quite similar results appear. No matter how great the observer's detachment, when the issue is raised in general terms it will appear incongruous that the legal order permits one person or group to retain a measurable gain that is the product of another's loss. This attitude has been expressed in other legal systems by adopting a legal technique which in certain large classes of transactions requires justification for retention of the gain. Even in legal systems like ours that have adopted a different technique, we find at least the attitude that a claim asserting enrichment through another's loss deserves special and more favorable treatment. The sense of justice supports the conclusion drawn from simple arithmetic, that a loss translated into another's gain is much more impressive than the loss would be alone. ${ }^{2}$

Yet it is obvious that the adoption of this principle as a "rule" of law would carry us far afield. By its terms it might seem to require a review of every transaction against an arithmetical standard. The 
equating of gains and losses could involve inquiries into the effects of legal transactions not only on the immediate parties but on third parties and persons still further removed. The principle stated by Pomponius and the Restatement therefore moves in a constantly changing perspective, like the planes in a modern painting. In some aspects it does take on the look of a "rule" of law, from which subsidiary rules or even the solutions of particular cases can be directly derived. But it is also a standard of judgment which cannot be applied universally in human affairs, and it expresses an aspiration that will never be realized.

If there is a single problem of unjust enrichment it arises from this constantly shifting perspective in which our proposition must be viewed. I hope I am one of the last to say that ideas walk on legs. Yet in reviewing the long history and our modern applications of the unjust enrichment idea, one is sometimes tempted to think that this idea does. It would be simplest of all if we could find the root of the difficulty in the deep-seated tendency of the human mind to overgeneralize. From the record it appears that a general principle prohibiting enrichment through another's loss appears first as a convenient explanation of specific results; it is an instrument for quite practical and intelligible purposes. Yet once the idea has been formulated as a generalization, it has the peculiar faculty of inducing quite sober citizens to jump right off the dock. This temporary intoxication is seldom produced by other general ideas, such as "equity," "good faith," or "justice," for these ideals themselves suggest their own relativity and the complexity of the factors that must enter into judgment. The ideal of preventing enrichment through another's loss has a strong appeal to the sense of equal justice but it also has the delusive appearance of mathematical simplicity. It suggests not merely the need for a remedy but a measure of recovery. It constantly tends to become a "rule," to dictate solutions, to impose itself on the mind. 


\title{
THE
}

\section{LAW OF QUASI-CONTRACTS.}

\author{
William Keener
}

\section{CHA PTER I.}

NATURE AND SCOPE OF THE OBLIGATION.

It is usual to divide Contracts into three classes, -

1. Simple Contracts.

2. Contracts under Seal.

Classification

3. Contracts of Record.

Where this classification is made, Simple Contracts are subdivided into -

1. Express Contracts.

2. Contracts implied in Fact.

3. Contracts implied in Law.

In this classification of Contracts, obligations of a quasicontractual nature are treated either as Simple Contracts or as Contracts of Record.

This treatment of Quasi-Contracts is, in 'the opinion of the writer, not only unscientific, and therefore theoretically wrong, but is also destructive of clear thinking, and therefore vicious in practice.

It needs no argument to establish the proposition that it is not scientific to treat as one and the same thing, an obligation that exists in every case because of the assent of the defendant, and an obligation that not only does not depend in any case upon his assent, but in many cases exists not- 
withstanding his dissent. And yet with this wide difference between simple contracts and quasi-contracts, the latter are generally treated to-day as a species of simple contract.

Equally objectionable in principle, though perhaps not so misleading in practice, is the classification of such quasicontracts as cannot by any possibility be treated as simple contracts, as contracts of record.

A true contract, whether it be a simple contract, a spe-

A genuine contract rests upon intention. cialty, a contract in the nature of a specialty, or a contract of record, exists as an obligation, because the contracting party has willed, in circumstances to which the law attaches the sanction of an obligation, that he shall be bound. Had he not so willed, he would not be under a contractual obligation. This statement is as true of a contract implied in fact as of an express contract. Indeed, the division of Simple Contracts into "express contracts" and "contracts implied in fact" does not involve a consideration of the principles of contracts at all. 2

In the case of a contract implied in fact, as much as in the case of an express contract, the plaintiff must prove that the defendant either made or accepted an offer which resulted in a promise on the defendant's part, and that the promise was not only in fact made, but that a sufficient consideration was given therefor. If the defendant gave in words a promise containing all the terms of the contract which the plaintiff claims that he made, for a consideration expressly requested in words by him, in exchange therefor, then the contract is an express contract. Thus, if $\mathbf{A}$ should say to B: "I will promise to sell you my horse $X$ for the sum of $\$ 500$ in cash if you will promise to purchase on these terms," and B should so promise, an express contract would be created thereby. Suppose, howerer, that $\mathbf{A}$ should write to a livery-keeper,

1 Marzetti v. Williams, 1 B. \& Speir, 77 N. Y. 144; Mertzog v.

Ad. 415; Montgomery v. Water Hertzog, $29 \mathrm{~Pa}$. St. 465. 
simply requesting him to send a coupé to his house at a cer. tain hour, and the coupé was sent and used by $A$, there would certainly be no express contract, since $A$ has never in words said that he intended to assume any obligation in favor of $B$. And yet A's conduct speaks quite as loudly as words, and leaves no doubt of his intention to enter into a contract with $B$ for the use of the coupé. No one would question that $A$ has communicated such an intention to $B$, and that he can be fairly said to have promised to pay him for the use of his property, and that to allow $\boldsymbol{A}$ to escape liability would defeat the intention of the parties quite as much as to allow him to refuse to be bound by his contract to sell the horse in the case first supposed.

The difference between the cases is a difference simply in the kind of the evidence used to establish the contract. In the "Express con. one case the language of contract is in terms used, and "Contracts because of the expressions used, the contract is called an implied in express contract; whereas in the other case the contract is established by the conduct of the parties, viewed in the light of surrounding circumstances, and is called a contract implied in fact.

The terms, "express contracts" and "contracts implied in fact," are used then to indicate, not a distinction in the principles of contract, but a difference in the character of the evidence by which a simple contract is proved. The source of the obligation in each case is the intention of the parties.

The term "contract implied in law" is used, however, to denote, not the nature of the evidence by which the claim of contracts the plaintiff is to be established, but the source of the obli- impicied ln lar gation itself. It is a term used to cover a class of obligations pendently of where the law, though the defendant did not intend to assume an obligation, imposes an obligation upon him, notwithstanding the absence of intention on his part, and in many cases in spite of his actual dissent.

The identity in principle of express contracts and contracts 
implied in fact, and the distinction between a genuine con.

Distinction in principle between genuine contracts and quasicontracts. tract, whether express or implied in fact, and a quasi-contract, commonly called a contract implied in law, is thus stated by Maine in his "Ancient Law" 1 :

"The part of Roman law which has had most extensive influence on foreign subjects of inquiry has been the law of Obligation, or, what comes nearly to the same thing, of Contract and Delict. 'The Romans themselves were not unaware of the offices which the copious and malleable terminology belonging to this part of their system might be made to discharge, and this is proved by their employment of the peculiar adjunct quasi in such expressions as Quasi-Contract and Quasi-Delict. 'Quasi,' so used, is exclusively a term of classification. It has been usual with English critics to identify the quasi-contracts with implied contracts; but this is an error, for implied contracts are true contracts, which quasi-contracts are not. In implied contracts, acts and circumstances are the symbols of the same ingredients which are symbolized, in express contracts, by words; and whether a man employs one set of symbols or the other must be a matter of indifference so far as concerns the theory of agreement. But a quasi-contract is not a contract at all. The commonest sample of the class is the relation subsisting between two persons, one of whom las paid meney to the other through mistake. The law, consulting the interests of morality, imposes an obligation on the receiver to refund; but the very nature of the transaction indicates that it is not a contract, inasmuch as the convention, the most essential ingredient of contract, is wanting. 'This word 'quasi,' prefixed to a term of Roman law, implies that the conception to which it serves as an index is connected with the conception with which the comparison is instituted by a strong superficial analogy or resemblance. It does nut denote that the two conceptions are the same, or that they belong to the same genus. On the contrary, it negatives the notion of an identity between them; but it points out that they are sufficiently similar for one to be classed as the sequel to the other, and that the phraseology taken from one department of law may be trans. ferred to the other, and employed without violent straining, in the statement of rules which would otherwise be imperfectly expressed."

1 3d Am. Ed. 352. 
Notwithstanding the existence and recognition of this well-defined line of demarcation between genuine contracts, whether express or implied, and quasi-contracts, there exist Confused use in practice of the the greatest confusion in the application thereof in practice. "contract." Thus Blackstone confuses contracts implied in fact and quasicontracts, when he says : ${ }^{1}$ -

"This contract or agreement may be either express or implied. Express contracts are where the terms of the agreement are openly uttered and avowed at the time of the making, as to deliver an ox, or ten load of timber, or to pay a stated price for certain goods. Implied, are such as reason and justice dictate, and which, therefore, the law presumes that every man undertakes to perform. As if I employ a person to do auy business for me, or perform any work; the law implies that I undertook, or contracted, to pay him as much as his labor deserves. If $I$ take up wares from a tradesman, without any agreement of price, the law concludes that I contracted to pay their real value."

While this definition of an implied contract is, at best, true only of quasi-contracts, all the cases put are illustrations of contracts implied in fact. Mr. Justice Lowrie, referring to the language just quoted from Blackstone, properly says: ${ }^{2}$

"There is some looseness of thought in supposing that reason and justice ever dictate any contracts between parties, or inpose such upon them. All true contracts grow out of the intentions of the parties to transactions, and are dictated only by their mutual and accordant wills. When this intention is expressed, we call the contract an express one. When it is not expressed, it may be inferred, implied, or presumed, from circumstances as really exist. ing; and then the contract, thus ascertained, is called an implied one. The instances given by Blackstone are an illustration of this.

"But it appears in another place, 3 Comm. 159-166, that Blackstone introduces this thought about reason and justice dictating contracts, in order to embrace, under this definition of an implied

12 Bl. Comm. 443.

' Hertzog v. Hertzog, $29 \mathrm{~Pa}$. St. 465, 467. 
contract, another large class of relations which involve no intention to contract at all, though they may be treated as if they did. Thus, whenever not our variant notions of reason and justice, but the common sense and common justice of the country, and therefore the common law or statute law, impose upon any one a duty, irrespective of contract, and allow it to be enforced by a contract remedy, he calls this a case of implied contract. Thus out of torts grows the duty of compensation, and in many cases the tort may be waived, and the action brought in assumpsit.

"It is quite apparent, therefore, that radically different relations are classified under the same term; and this must often give rise to indistinctness of thought. And this was not at all necessary; for we have another well-authorized technical term exactly adapted to the office of making the true distinction. 'The latter' class are merely constructive contracts, while the former are truly implied ones. In one case, the contract is mere fiction, - a form imposed in order to adapt the case to a given remedy; in the other, it is a fact legitimately inferred. In one, the intention is disregarded; in the other, it is ascertained and enforced. In one, the duty defines the contract; in the other, the contract defines the duty."

Yet the learned Justice, after so intelligently criticising Blackstone, falls into the same confusion of statement when he says, in the same opinion: ${ }^{1}$ -

"The law ordinarily presumes or implies a contract whenerer this is necessary to account for other relations found to lave existed between the parties.

"Thus if a man is found to have done work for another, and there appears no known relation between them that accounts for such service, the law presumes a contract of hiring. But if a man's house takes fire, the law does not presume or imply a contract to pay his neighbors for their services in saving his property. The common principles of luman conduct mark self-interest as the motive of action in the one case, and kindness in the other; and therefore, by common custoin, compensation is mutually counted on in one case, and in the other not."

Plainly, in the case put by Mr. Justice Lowrie, the inferance of a contract is one of fact; and in another part of the

1 Hertzog v. Hertzog, 29 Pa. St. 465, 468. 
same opinion the learned Justice clearly regards the inference as one of fact and not one of law, when he says : ${ }^{1}-$

"Erery induction, inference, implication, or presumption in reasoning of any kind, is a logical conclusion derived from and demanded by certain data or ascertained circumstances. If such circumstances demand the conclusion of a contract to account fur them, a contract is proved; if not, not. If we find, as ascertained circumstances, that a stranger lias been in the employment of atoother, we immediately infer a contract of hiring, because the principles of indiriduality and self-interest, common to human nature, and therefore the customs of society, require the inference."

In the opinion of Lord Justice Lindley, it was the failure of Lord Justice Brett to recognize the distinction in question, which led him to doubt ${ }^{2}$ that a lunatic was liable for necessaries furnished to him by one knowing of his lunacy. On this point Lord Justice Brett expressed himself as follows:

"A question has been flushed, if I may use the word, in this case which it is not necessary to decide, namely, whether if a person supplies necessaries to a lunatic, knowing of the lunacy at the time, a contract on the part of the lunatic to pay for them ean be implied. I give no opinion upon that point. It has not been fully argued to-day, and it appears to me to involve a very difficult point of law, which I do not think has ever been settled by authority. For ny part I should doubt whether in favor of a person who knows of the lunacy you can imply a contract to pay for a supply of necessaries to a lunatic."

In Rhodes $v$. Rhodes, ${ }^{3}$ Lord Justice Lindley, referring to the doubt raised by Lord Justice Brett, said:-

"The question whether an implied olligation arises in favor of a person who supplies a lunatic with necessaries is a question of law, and In re Weaver, a doubt was expressed whether there is any obligation on the part of the lunatic to repay. I confess I cannot participate in that doubt. I think that that doubt has arisen from the unfortunate terminology of our law, owing to which

1 Hertzog v. Hertzog, $29 \mathrm{~Pa}$. St. $465,469$.
2 In re Weaver, $21 \mathrm{Ch}$. D. 615 , 620.

B 44 Ch. D. 94, 107. 
the expression 'implied contract' has been used to denote, not only a genuine contract established by inference, but also an obligation which does not arise from any real contract, but which can be enforced as if it had a contractual origin. Obligations of thr class are called by civilians obligationes quasi ex contractu."

It was this confusion of ideas that caused the counsel in Sceva $v$. True ${ }^{1}$ to contend that as an insane person was not able to contract, the defendant was not liable for necessaries furnished to her by one knowing her to be insane. The counsel's argument in that case was as follows :-

"The foundation principle of the entire law of contracts is, that the parties must have the capacity to contract, and must actually exercise their faculties by contracting. Here there was 1 , capacity, for there was but one nind; no contract was made, and no attempt was made to make one. The two vital facts, without which no contract, tacit or express, can exist, - capacity and its exercise, - are wanting. Was there an implied contract? What does that term mean? In thousands of cases, in the books, we know just what it means. The parties have capacity to contract; facts, circumstances, few or many, clear or complicated, exist, which lead the minds of the jurors to the conclusion that the minds of the parties met. Minds may meet by words, acts, or hoth. The words even may negative such meeting; but 'acts which speak londer than words' may conclude hin who denies a tacit contract. Aside from cases where the eapacity to contract is wanting, no instance now occurs to us in which the implied contract camot be supported upon these principles, and the familiar doctrines of waiver an estoppel. . . It is another fundamental principle that no one, by voluntarily performing services for another, ean make that of he $r$ his debtor. If these principles apply to cases where the contracting mind is wanting, they settle this case. We know it is sometimes said, in such a case, 'the law will imply a contract.' What does that mean? As it seems to us, only this: that where $\mathrm{A}$, who, has capacity to contract, furnishes $B$, who is totally destitute of such capacity, what is proper for $B$ to have, the judges wll turn the bench into a broker's board, will substitute themselves for B, make a contract where none existed, cause it to relate back to the

153 N. H. 627. 
voluntary acts of $\mathbf{A}$, and then sit in judgment upon and enforce their own contract. It is a perversion of language to call such a meriornance a contract of any kind. It is judicial usurpation. The Coustitution gave the court no such power. The court ha no fuwer to make contracts for people: it can onl inter one where a jary might."

'Tu this argument the court made the following conclusive allswer : -

. We regard it as well settled by the eases reforted $t$ in the bicis of counsel, many of which liave been $\cdot$ mntented on at I. : th by Mr. Shirley for the defendant, that an insane person, an nini, or a person utterly bereft of all sense and reason by the si.t? stroke of accident or disease, may be held liable, in assumproit, for necessarie furnished to hin in gond faith whle in that unfortunate and helpless condition. And the reason upon Which this rests are too broad, as well as too sensible and lumane, a) be urerborne by any deductions which a refined logic may make irom the circumstances that in such cases there can be no contract I: [romise in fact, no meeting of the minds of the parties. The cases $f^{\text {ut }}$ it on the ground of an implied contract; and by this is wot meant, as the defendant's counsel seems to suppose, an actual crisinct, - that is, an actual meeting of the minds of the 1 rties, : ' actual mutual understanding, to be inferred from language, : $:-$ and cirennstances, by the jury, - but a contract and promise, -i.l to be implied by the law, where, in point of fact, there was no coniract, no mutual understanding, and so no promise. The irfenlant's counsel says it is usurpation for the court to hold, as matier of law, that there is a contract and a promise, when all :he widence in the case shows that there was not a contrat, nor the semblance of one. It is doubtless a legal fiction, invented a:d used for the sake of the remedy. If it was originally usurpatimn. certainly it has now become very inveterate, and firmly fixed in the body of the law." 1

Not only has this identification in classification, of quasicontracts witl genuine contracts, led to a confusion of ideas,

1 Further jllustrations of this con. found in the discussion of the scope fusion of ideas, which might be mul- of quasi-contract.

tiplied almost indefinitely, will be 
but it has also rendered the interpretation of written laws or

Meaning of the term

"implied contract" when used in sta. tutes.

statutes exceedingly difficult where the word "contract" is used ; thus, for example, in Dusenbury $v$. Speir, ${ }^{1}$ the legality of an arrest turned upon the meaning to be given to the phrase "contract express or implied," as used in a statute regulating arrests in civil actions. The plaintiff had been arrested in an action, corresponding to the common law action, for money had and received, brought to recorer money which the plaintiff (the defendant in that action) had fraudulently obtained. The plaintiff was arrested on a warrant issued on the theory that the action was that of contract, express or implied, within the meaning of the statute. It was held that his liability was in quasi-contract, and not in contract, and that as the phrase "contract express or implied" was used in the statute with reference solely to genuine contracts, the arrest was illegal, and the judgment of the lower court was reversed. And yet the court, whose judgment was reversed by the Court of Appeals, recognized as fully as did the Court of Appeals that the obligation to return the money was a quasi-contractual, and not a contractual, obligation. ${ }^{2}$

177 N. Y. 144.

2 Probably no clearer statement of the distinction between a genuine contract and a quasi-contract can be found than is contained in the following statement, taken from the opinion of Mr. Justice Danforth in this case: -

"We cannot agree with the learned judge in this construction of the statute. On the contrary, we think that the express contract referred to in the statute is one which has been entered into by the parties, and upon which, if broken, an action will lie for damages, or is implied, when the intention of the parties, if not expressed in words, may be gathered from their acts and from surrounding circumstances; and in either case must be the result of the free and bona fide exercise of the will, producing the aggregatio mentium, the joining together of two minds, essential to a contract at common law. There is a class of cases where the law prescribes the rights and liabilities of persons who have not in reality entered into any contract at all with one another, but between whom circumstances have arisen which make it just that one should have a right, and the other should be subject to a liability, simi- 
In O'Brien 2 . Young, the question incolved was the construction of the statute reducing the rate of interest from seven per cent to six per cent. The statute contained a clause excepting from its operations "any contract or obligation" made before the passage ut the $A$ ct. It was contended that a judgment obtaincd before the passage of the Act was eximpted from its operations, and that the judgment creditor iras. therefore, entitled to seven per cent interest. But the cuti:t rerersed the judgment of the lower court, holding that the clause in question referred, not to quasi-contracts, but to genuine contracts only, and that, therefore, the judgment creditor was entitled to only six per cent after the passage of the Act.

But in The Gutta Percha Shoe Co. v. Mayor, ete., it was held that although a judgment was not a genume contract, ret an attachment could issue in an action bronght on a foreign judgment under a section of the code of eiril procedure, allowing an attachment against property, in an action brought for "breach of contract, express or implied, other than a contract to marry." Yet the same court held, in Rominston Paper Co. v. O'Dougherty, ${ }^{3}$ that an attachment could

lar to the rights and liabilities in certain cases of express contract. Tinss. if one man has obtained money from another through the medium of oppression, imposition, extortion, or deccit, or by the commission of a trespass, stuch money may he recovered back, for the law implies a promise from the wrongdoer to restore it to the rightful orner, although it is obvious that is the rery opposite of his intention. Implied or constructive contracts of this nature are similar to the constructive trusts of counts of equity, nud in fact are not contracts at all. And a comewhat similar distinction is recognized in the civil law, where it is said: "In contracts it is the consent of the contracting parties which produces the obligation; in quasi-contracts there is not any consent. 'The law alone. or natural equity, produces the obligation by remlering obligatory the fact from which it results. Therefore these facts are called quasi-contracts, because, without being contracts, they proince obligations in the same manner as actual contracts." ",

$195 \mathrm{~N}$. Y. $42 \mathrm{~S}$.

$2108 \mathrm{~N} . \mathrm{Y} .276$.

3 96 N. Y. 666, affirming 32 Ifun, 255. 
The law of remedies the reason for the classification of quasi-contracts.

not issue under the same section of the code, in an action brought to enforce a statutory liability created by the Legislature of New York to pay the cost of an action.

The question naturally arises, why a classification productive of so much confusion was ever adopted. The answer to this question is to be sought, not in the substantive law, but in the law of remedies.

The only forms of action known to the common law were actions of tort and contract. If the wrong complained of would not sustain an action, either in eontract or tort, then the plaintiff was without redress, unless the facts would sup-
port a bill in equity.

Although from time to time the judicial view of substantive rights brondened under the leavening effect of equity and other considerations, the broadening process did not lead to the creation of remedies sounding in neither contract nor tort. The judges attempted, however, by means of fictions, to adapt the old remedies to the new rights, with the result usually following the attempt to put new wine into old bottles. Thus, largely through the action of assumpsit, that portion of the law of quasi-contract usually considered under the head of simple contracts, was introduced into our law.

In the action of assumpsit, as the word assumpsit implics, whether it be special or indebitatus assumpsit, a promise must always be alleged, ${ }^{2}$ and at one time it was an allegation which had to be proved. ${ }^{3}$ It was only natural, therefore, that the courts in using a purely contractual remedy to give relief in a class of cases possessing none of the elements of contract, should have resorted to fictions to justify such a course. This was done in the extension of assumpsit to quasi-contract; and the insuperable difficulty of proving a promise where none cxisted was met by the statement that

11 Spence, Eq. Jur. 243; Woods v. Ayres, 39 Mich. 345 ; Sceva $v$.
True, 53 N. H. 627.
2 Chitty on Pleading, 301.

Ames, The IIistory of Assump- 
"the law implied a promise," The statement that the law imposes the oblization would not have met the difficulties of the situation, since the action of assumpsit presupposed the esistence of a promise. The fiction of a promise was adopted then in this class of cases solely that the remedy of assumpsit might be used to cover a class of cases where, in fact, there was no promise.

It might be asked: Why did the court extend to this class of obligations the remedies peculiar to contracts rathor than the Distinctim be. remedics peculiar to tort? The right conferred in guasi- tween ritustcontract, and the right, the violation of which constitutes tort. a tort, undoubtedly possess this common characteristic,that the obligation is imposed by operation of law, regard. less of the consent of the defendant. But treating a tort as the riolation of a right in rem, the obligations differ in an important particular; for while to aroid committing a tort, one need only forbear,' to discharge the obligation imposed by quasi-contract one must act. ${ }^{2}$ It is true that the obligation imposed by a contract may be simply to forbear; but the obligation most generally assumed under a contract requires one to act, and therefore contract rather than tort would naturally suggest an analogy. Another consideration would also suggest the analogy of contract rather than of tort; not only in most cases where a quasi-contractual obligation is imposed has the defendant not acted in violation of a right in rem, in consequence of which the law could impose an obligation; but in many cases he has either not acted at all,-as, for example, where an absent husband, who is ignorant of the death of his wife, is obliged to reimburge one who has defrayed the expenses attendant upon her burial, - or, if he has acted, has acted with the consent, and perhaps the co-operation, of the plaintiff; as, for example, ${ }^{2}$ Austin, Jurisprudence, Lect.
XIV.

2 Illustrations of this proposition

will be given in discussing the scope of the obligation. 
Sources of the quasi-contractual obligation.

where a defendant is obliged to refund money which he has received from the plaintiff, both parties acting under a misapprehension.

It remains to consider the scope of quasi-contract.

Quasi-contracts may be said in general to be founded, ${ }^{1}-$

1. Upon a record.

2. Upon a statutory, or official, or customary duty.

3. Upon the doctrine that no one shall be allowed to enrich himself unjustly at the expense of another.

The obligation created by a judgment which, as Sir William A judgment is not a contract
but a quasicontract.

Anson las said, ${ }^{2}$ is unfortunately styled in our law a contract of record, resting, not upon the agrcement of the parties, but regardless thereof, is a quasi-contractual, and not a contractual, obligation. ${ }^{3}$ In Louisiana $v$. New Orleans, ${ }^{4} \mathrm{Mr}$. Justice Field, delicering the opinion of the court, in support of the decision that a judgment was not a contract within the meaning of that word as used in the clause of the Constitution forbidding the enactment by a State of a law impairing the obligation of a contract, said : -

"A judgment for damages, estimated in money, is sometimes called by text-writers a sjecialty or contract of record, because it establishes a legal obligation to pay the amount recovered; and by a fiction of law a promise to pay is implied where such legal obligation exists. It is on the principle that an action ex contractu lies upon a judgment. But this fiction cannot convert a transaction wanting the consent of parties into one which necessarily
implies it."

A statutory obligation which does not rest upon the consent of the parties, is clearly quasi-contractual in its nature. ${ }^{5}$ In

1 Ames, The History of Assumpsit, 2 Harv. Law Rev. 64.

${ }^{2}$ Anson, Contracts, 6 ed. 7.

3 Biddleson v. Whytel, 3 Burr. 1545 ; State of Louisiana $v$. New Orleans, 109 U. S. 285; O'Brien $v$. Young, 95 N. Y. 428.

109 U. S. $28 \tilde{}$.
5 Steamship Co. $v$. Joliffe, $2 \mathrm{~W}$ all. 450 ; Louisiana $v$. New Orleans, 109 U. S. 285; Inhabitants of Milford v. Commonwealth, 144 Mass. 64; Woods v. Ayres, 39 Mich. 345; McCoun v. New York Central \& Hartford R. R. Co., 50 N. Y. 176. 
Steamboat Co. v. Joliffe, ${ }^{1} \mathrm{Mr}$. Justice Field, in discussing the nature of the claim for half-pilotage fees under a statute allowing such fees, where a pilot's services are offered and declined, thus distinguishes between a contract liability and a liability imposed by statute:-

"The transaction in this latter case, between the pilot and the master or owners, cannot be strictly termed a contract, but it is a transaction to which the law attaches similar consequences; it is a quasi-contract. The absence of assent on the part of the master or owner of the vessel does not change the case. In that large class of transactions designated in the law as implied contracts, the assent or convention which is an essential ingredient of an actual contract is often wanting. . . .

"The claim of the plaintiff below for half-pilntage fees resting upon a transaction regarded by the law as a quesi-contract, there is no just ground for the position that it fell with the repeal of the statute under which the transaction was had."

In Inhabitants of Milford $v$. Commonwealth, ${ }^{2}$ the court, discussing the nature of the plaintiff's claim for the support of a pauper under a statute imposing upon the Commonwealth an obligation to reimburse the plaintiff for the expenses so incurred, recognizes the distinction between a contract liability and a liability imposed by statute, in the following lauguage :-

"The law regards the money as expended at the implied request of the defendant, and a promise to pay the money is said to be inplied from the liability created by the statute. A contract may he expressly made, or a contract may be inferred or implied when it is found that there is an agreement of the parties and an intention to create a contract, although that intention has not been expressed in terms of contract; in either case, there is an actual contract. But a contract is sometimes said to be implied when there is no intention to create a contract, and no agreement of parties; but the law has imposed an obligation which is enforced as if it were an obligation arising ex contractu. In such a case there is not a contract, and the obligation arises ex lege."

12 Wall. 450 .

2144 Mass. 64. 
Of a quasi-contractual nature, it is submitted, is the duty of

Nature of the obligation of a innkeeper. a carrier, founded upon the custom of the realin to receive and to carry safely. That the liability in such cases arises, not from contract, but from a duty, is clear. ${ }^{1}$ While it is true that the liability is ordinarily described as one in tort, jt is submitted that it has been so described because of the usual classification of legal rights into contracts and torts, and that since the obligation imposed upon the carrier is to act, the obligation is really quasi-contractual in its nature, and not in the nature of a tort. If this be the proper classification of the duties imposed by law upon a carrier, it must necessarily be true of the common law liability of an innkeeper to receire guests, or to keep their goods safely. ${ }^{2}$ The obligation in these cases seems analogous in principle to the obligation imposed by the Austrian law upon one in possession under a fidei commiss in favor of his successor, as to the care of the property. That liability is thus described by Lord Justice Cotton in Batthyany $v$. Walford $:^{3}-$

"It appears, as far as I understand the evidence, that the law of Austria (I will omit Hungary, because the Hungariau law on this head is practically the same as that of Austria) is this: The tenant in possession under a fidei commiss, both of real and personal estate, is considered in possession in a different way from that in which a tenant for life or a tenant in tail in England stands. There are $n 0$ trustees, and if he loses any portion of the personal estate, which apparently stands as regards the provision of the fidei commiss nearly in the same position as real estate, he must make that loss good. As regards the real estate, he is answerable, at the time when he surrenders, by death or otherwise, the possession of the property in the fidei commiss, for the deterioration of the estate which has taken place since the time when he took possession. $\mathrm{He}$ is considered as having possession of the estate, not only for his

1 Anonymous, 12 Mod. 3 ; Marshall v. York, N. \& B. Railway Co., 11 C. B. 655; Austin $v$. Great Western Railway Co., L. R. 2 Q. B.

2 Morgan v. Ravey, 6 H. \& N. $265,275$.

36 Ch. Div. 269, 278. 442,445 . 
own benefit, but subject also to an obligation to hand it over to his successor in as good a condition as when he took possession, subject only to this, that he can excuse himself if he shows that the deterioration took place without any fault ('culpa,' as it is called) on his part. But, as I understand the evidence, the claim according to the law of Austria is not in the nature of damages for default, but a claim under an obligation to keep the property in as good condition as the late possessor found it, with liberty to excuse himself from making good the deficiency if he can show that it was not caused by any default of his own. That, in my opinion, is not a claim simply depending on tort, and does not come within the rule of actio personalis moritur cum persona. It may be that it is 3 wrong which has produced the deterioration; but the claim, in my opinion, is one depending on the implied contract or obligation which, by the law of Austria, every possessor under a fidei commiss takes upon himself when he enters into possession.

"It was contended that there could be no such liability of a personal representative for anything connected with default, unless there was an express contract. No authority was referred to in support of that proposition, and in my opinion it is contrary to English law. ... It is not only where there is an express contract that a suit grounded on some default of the person whose representative is sued can be maintained; but if the position of the parties was such that the law of England would imply a contract from that position, then on assumpsit the executor might still be held liable. There are many cases where an action can be brought upon an obligation implied by law in consequence of the position which the parties have undertaken one to another."

Of this nature also, it is submitted, is the obligation of a Sheriff's oblisheriff to levy execution and pay the proceeds thereof to gation is quasijudgment creditor. ${ }^{1}$

By far the most important and most numerous illustrations of the scope of quasi-contract are found in those cases where the plaintiff's right to rocover rest unjust enrichthe plaintiff's right to recover rests upon the doctrine that ment the most a man shall not be allowed to enrich himself unjustly at the source of the expense of another. As the question to be determined is not the defendant's

1 Speake v. Richards, Hobart, 206; 3 Bl. Comm. 163. 
intention, but what in equity and good conscience the defendant ought to do, the liability, while enforced in the action of assumpsit, is plainly of a quasi-contractual, and not contractual nature.

It is on the theory of quasi-contract, founded on the doc-

Liability of a lunatic for necessaries is quasi-contractual. trine of unjust enrichment, that an insane man, known to be insane by the party furnishing necessaries, is held liable therefor. That such is the nature of the liability is evident, not only from the fact that he has no contracting mind, but also from the fact that he is equally liable for necessaries furnished at a time when there was no attempt on his part to contract. 1

The nature of the obligation incurred by a lunatic for necessaries was thus stated by Lord Justice Cotton, in Rhodes $v$. Rhodes : ${ }^{2}$ -

"Now the term 'implied contract' is a most unfortunate expression, because there cannot be a contract by a lunatic. But whenever neccssaries are supplied to a person who by reason of disability cannot himself contract, the law implies an obligation on the part of such person to pay for such necessaries out of his own property. It is asked, Can there be an implied contract by a person who cannot himself contract in express terms? The answer is, that what the law implies on the part of such a person is an obligation, which has been improperly termed a contract, to repay money spent in supplying necessaries."

Of a quasi-contractual nature also, is the obligation of an The liability of infant to pay for necessaries. It is usually stated that an an infant for necessaries is quasi-coninfant is bound by his contract for necessaries. But if, as is held in many jurisdictions, the infant is bound to pay for necessaries, not the contract price, but the reasonable value thereof, it would seem clear that he is not liable on his contract. By the terms of his contract he is required to pay a stated sum, and not the reasonable value for necessaries fur-

I In re Rhodes, 44 Ch. D. 94 308; Sceva v. True, 53 N. H. (semble); Saber $v$. Lufkin, $56 \mathrm{Me} .627$.

244 Ch. D. $94,105$. 
nished. If he is bound by lis contract to pay for necessaries, then of course he should be liable in damages for haring, in violation of his contract, refused to pay therefor; and if liable in damages, the amount of the plaintiff's recovery would be determined, not by the reasonable value of the necessaries, but by the price agreed upon, - since had the infant performed his contract, the plaintiff would have reccired that amount of money. When, therefore, the infant is required to pay, not the stated price, but simply the reasonahle value of the necessaries, the obligation differs from that which he assumed; and though the result reached, as to the amount of the recovery, by a plaintiff in any given case, may be the same as would have been reached had the recovery been had on the theory of the plaintiff's being entitled to the price agreed upon, yet such a result is purely accidental. The doctrine, therefore, ${ }^{1}$ that while the payee of a note given by an infant for necessaries can recover on the note, he can recover, not the amount thereof, but simply the reasonable value of the necessaries, must be regarded as an anomaly in procedure. In no other way can the result actually reached in some jurisdictions ${ }^{2}$ - that while the payce of the note can recover in the action on a note the value of necessaries furnished, an indorsec thercof has no right of action - be explained.

That the liability is really in quasi-contract seems to be recognized in the jurisdiction which has furnished the leading authority ${ }^{3}$ for the proposition that the payee, whilc not allowed to recover the amount of the note, can, in an action brought on the note, recorer the value of the necessaries. In Trainer $v$. Trumbull, where the court held an infant liable for necessaries furnished in the absence of contract, Allen, $J$., delivering the opinion of the court, said : -

"The practical question in this case is, whether the food, clothing, etc., furnished to the defendant were necessaries for which he

\footnotetext{
11 Daniel Neg. Inst., 4th ed, s 226 .

2 Ibid.

8 Farle $v$. Reed, 10 Met. 387.

4141 Mass. 527, 530.
} 
should be held responsible. . . The question whether or not the infant made an express promise to pay, is not important. He is held on a promise implied by law, and not, strictly speaking, on his actual promise. The law implies the promise to pay, from the necessity of his situation; just as in the case of a lunatic. (1 Chit. Con. 11th Am. ed. 197; Hyman v. Cain, 3 Jones (N. C.), 11 ; Richardson $x$. Strong, 13 Ired. 106; Gay $v$. Ballou, 4 Wend. 403 ; Epperson v. Nugent, 57 Miss. 45, 47.) ln other words, he is liable to pay only what the necessaries were reasonably wortl, and not what he may improvidently have agreed to pay for them. If he has made an express promise to pay, or has given a note in payment for necessaries, the real value will be inquired into, and he will be held only for that amount."

Such also, it is submitted, is the nature of the liability of a The liability of husband for necessaries furnished a wife whom he has a husband for necessaries is quasi-conwrongfully refused to support, where the cireumstances do quasi-con-
tractual. not justify the party supplying the necessaries in supposing that the husband in fact authorized the wife to pledge his credit. In such cases it is settled that one furnishing necessaries can recover against the husband therefor, notwithstanding his knowledge at the time he furnished them that the husband did not intend to pay therefor. It is usually stated that the wife, in snch circumstances, is authorized to pledge the credit of the husband. Since, however, the husband may be liable for necessaries furnished even though the wife made no attcmpt to pledge his credit, - as, for example, for necessaries furnished a deserted wife while she is unconscioxs; and since, furthermore, the husband is held liable for necessaries furnished a wife while he is incapable of contracting, - as where necessaries are furnished a wife while the husband is insane, ${ }^{1}$ - the better form of statement would seem to be that an obligation is imposed by law upon the husband to pay for necessaries furnished in such circumstances. That such is the nature of the liability was recognized in Cunningham $v$. Reardon, ${ }^{2}$ where Hoar, J., delivering the opin-

1 Read v. Legard, 6 Ex. $636 . \quad$ 2 98 Mass. 538. 
ion holding the husband liable for necessaries furnished a wife, said :-

"The husband, who by his cruelty, compels his wife to leave him, is considered by the law as giving her thereby a credit to procure necessaries on his account; and is responsible to any person who may furnish her with them. This responsibility extends not only to supplies furnished her while living, but to decent burial when dead. Its origin is not merely and strictly from the lands in need. her his agent to procure the articles follow for which the defendant If it were so, the consequence would end with the life of the agent. coutends, rather an authority to do for him what law and duty But it is ram to do, and which he neglects or refuses to do for himself; and it is applicable as well to supplies furnished to the is sick, insensible, or insane, and to the care of her wife when she is sek, instracts expressly made by her." 1

be put the obligation of a father, Liability of where such obligation is imposed by law, to pay for neces- necessaries saries furnished a child whom he has refused to support. ${ }^{2}$ tractual.

That the right to recover money paid under mistake rests upon a quasi-contractual obligation is a self-evident proposi- Quasi-contract tion, when it is remembered that in the typical cases where $\begin{gathered}\text { the basis of the } \\ \text { oblion to }\end{gathered}$ money is recovered as paid under mistake, the mind of the $\begin{gathered}\text { refund money } \\ \text { paid under }\end{gathered}$ plaintiff as well as the mind of the defendant was directed, mistake. not to the creation of, but the discharge of an obligation. ${ }^{3}$

1 The theory of holding a husband liable in quasi-contract to prerent an unjust enrichment, where the facts will not warrant the inference of a contract, is of very early origin in our law. An illustration of this is found in case V. of Jenkins' Century Cases, p. 4, reported as follows: -

“The Wife of A. receives $£ 10$ to the Use of $A$. and this comes to the Use of her Husband in a convenient or necessary Way; altho' the Husbaud did not command it, nor con- ent afterwards, he is liable to this Debt, and the Count shall be of a Receipt by the Hands of the HusSuch manner of Count will erve in Debt in this Case. The Reason is, the Wife's Contract is roid; and it ought not to be alleged in the Count, but the Count ought to be as above. Nemo debet locupletari ex alterius incommodo."

2 Gilley v. Gilley, 79 Me. 292; Cromwell v. Benjamin, 41 Barb. 558.

S See infra, Ch. II. p. 26, passim. 
Waiver of Tort.

Recovery by a plaintifi in decontract.

Obligation of a defendant his breach of contract.

Obligation of a defendant who has requested but has not con. tracted to pay tracted to pas

Obligation of a defendant for benetits conferted without request.
That quasi-contract is the basis of liability where a plain. tiff is allowed to sue a tort-feasor in assumpsit is equally clear, since it is the want of assent on the part of the plaintiff that renders the defendant's act tortious. It is idle to speak of the possibility of contract where there is not eren the suggestion of a meeting of minds. For example: A takes B's horse, believing him to be his own, and sells it. $B$ can recover from $A$, in a count for money had and received, the proceeds of the sale. To speak of a contract in such a case is simply to attempt to deceive one's self by a form of words. ${ }^{1}$

Quasi-contractual, of necessity, is the nature of the obligation of the defendant, where a liability exists to compensate the plaintiff for benefits received under a contract which the plaintiff cannot enforce because he has failed to comply with the conditions thereof. ${ }^{2}$

When it is for any reason conceded - e.g. illegality, the stat ute of frauds, impossibility of performance - that a defendant is not liable to a plaintiff for a failure to perform a contract made with the plaintiff, and yet it is held that he is liable in assumpsit, or other contractual remedy, for benefits conferred by the plaintiff under the contract, such liability is necessarily quasi-contractual, and rests on the doctrine of unjust enrichment. ${ }^{3}$

Of this character also is the liability of a defendant for benefits received, which, though requested by him, were not conferred under a contract, because of some misunderstanding of the parties, or other reason, preventing the creation of a contract. ${ }^{4}$

Where the benefit for which the plaintiff seeks a recovery was conferred without the assent of the defendant, there can, of course, be no contract, and unless the facts would establish a liability in tort, the plaintiff must proceed on the theory of quasi-contract. ${ }^{5}$

I See infra, Ch. III. p. 159, passim. See infra, Ch. VI. p. 315, passim. - See infra, Ch. IV. p. 214, passim. 'See infra, Ch. VII. p. 341, passim. - See infra, Ch. V. p. 267, passim. and Ch. VIII. p. 363, passim. 
Where one is compelled to indemnify, or contribute to the expenses of one with whom he has not consciously entered Indemnity into any relationship, or with whom he has not consciously or tion. roluntarily had any dealing, the elements of a contract are necessarily wanting, and the basis of the liability is that in equity and good conscience he should either assume or share a burden which was borne by the plaintiff. 1

Where money is paid to another, who demands it as his right, or as a condition of allowing the plaintiff to exercise Recovery of a right, it may well be, and is in many instances, held that the money pald money so paid can be recovered $;^{2}$ but to speak of an implied contract in such a case is idle, if anything more is meant than that the obligation is imposed by law, and is therefore a quasicontract. The statement shows the absence of assent on the part of the defendant, and therefore the absence of a contract.

1 See infra, Ch. IX. p. 388, passim.

See infra, Ch. X. p. 411, passim, and Ch. XI. p. 426, passim. 


AUSTIN т. BURGE.
(Kansas City Court of Apprals. Missouri.
May 15, 1911.)

156 Mo. App. 286, 137 S.W. 618
A case quite applicable to the encts here Involved arose in FogE $r$. Athenemm, $44 \mathrm{~N}$. H. 115, $82 \mathrm{An}$. Dec. 191 . Thre the Indevendent Democrat newspaper was forwarled weekly by mall to the defendint from Mny 1,1847 , to May 1, 1810, when a blll wns presented, which defendant objected to paying on the ground of not linving subscrlbed. Payment was, however, finally made, and directions given to discontinue. The paper chnnged ownerahlp, and the order to stop It wns not known to the new proprietors for a zenr: but, after being notined of the order,

thes nerertheless continucel to send it to lefomint untll $1 \mathrm{S60}, \mathrm{a}$ perlod of 11 years, and defenflant contmued to recelve it through the post ofllec. Pnynent was severnl times demamlet during thls tlme, but refused on the fromd that there was no subserintion. The court snld thnt: "During this perlod of thme the flefendants were ocenslomilly requested, br the plaintifr's agent, to pay their blil. The answer whe, by the defeminnts, 'Te are not subscribers to your newspaner.' But the evilence is the defendants used or kept the phalutir's * * Dewspaners, and never orrered to return a number, as they reasonably might have done, if they would have nvolled the llabllity to pny for them. Nor flll they ever decline to take the newsmpers from the post oflice." The defendint was held to have necented the papers, and to hare become liable for the subscription price br Implication of law.

In Ward v, Powell, 3 IIar. (Del.) 379, it was reclued that an Implled agreement to phy for a newsp:iper or perlodical arose by fhe continued taking and accepting the pafer from the post onlee, and that "If a party, without subscribing to a paper, declines tnkling it ont of the post omce, he cannot become linble to nay for 1t; and a subscilber may cease to be such at the end of the year. by refusing to trike the papers from the post offec, and retuming them to the editor as nollce of sucl determination." In Goodland r. Te Clair, 78 Wis. 170, 47 N. W. 208, it wns held that if a person receives a paper froin the post once for a year, without refusing or returning $1 t$, he was linble for the yenr's subscrintlon. And a llke obllgation was held to arlse in the case of Weatherby $v$. BonInm, 5 C. P. 228.

The preparation and publleatlon of a newsmerer involves much mental and physical in. her, as well as an outlay of money. One who accepts the paper, by continuousiy takIng it from the post ofnce, recelves a bencfit and pleasure arlsing from sucl labor and expewituro as fully ns if he lind approprlat. rl any other produet of nother's lnbor, and ly such act he must be hell liable for the siliserfition price. On the defendant's own whilence, plaintim should linve recovered.

The fudgment will therefore- he reversed, and the cause remanded. All concur. 
Did the objective acts of Burge evidence a promise to pay for the newspapers? What should you do if you receive merchandise that you didn't order? Must you return it? Can you use it? This may not be a significant problem, but it can be an annoyance. Such selling techniques as those employed by the Book of the Month Club are similar, but of course you do agree to purchase the current selection if you fail to return the notice they send you.

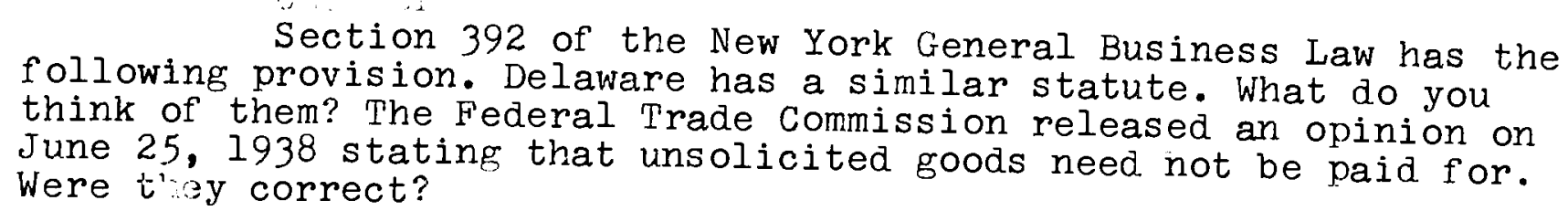

Section 392 of the New York General Business Law has the following provision. Delaware has a similar statute. What do you think of them? The Federal Trade Commission released an opinion on June 25,1938 stating that unsolicited goods need not be paid for.
Were tioy correct?

2. No person, firm, partnership, association or corporation, or ayent or employee thereof, shall, in any manner, or by any means, of ter fior and unsolicited sending of andise, where the of fer includes the voluntary dered or requested by the recipient, either merchandise not artually orreceipt of any sucl unsolicited gient, either orally or in witing. "The purposes be deemed an unconditionals, wares or merchindise shall for all or dispose of the same in any manner gift to the recipient who may use on his part to the sender. As amended L.1968, c. 428, eff. Sept. $1,1968$.

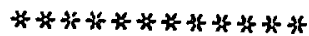 \\ VICKERY V. RITCHIE \\ Supreme Judicial Court of Mascachusetts \\ 202 Mass. 247.88 N.E. 835,26 L.R... 'n.4.j $810(1909$
}

Knowlton, C.J. This is an action to recover a balance of $\$ 10,467.16$, alleged to be due the plaintiff as a contractor, for the construction of a Turkish bath house on land of the defendant. The parties signed duplicate contracts in writing, covering the work. At the time when the plaintiff signed both copies of the contract the defendant's signature was attached, and the contract price therein named was $\$ 33,721$. When the defendant signed them the contract price stated in each was $\$ 23,200$. Lntil the building was completed the plaintiff held a contract under which he was to receive the larger sum, while the defendant held a contract for the same work, under which he was to pay only the smaller sum. This resulted from the fraud of the architect who drew the contracts. and did all the business and made all the payments for the defendant. The contracts were on typewritten sheets, and it is supposed that the architect accomwritten, before the bhanging the sheets on which the price was to the defendant. signing by the plaintiff, and before the delivery tween the two writine parties did not discover the discrepancy bepleted. Fach of thes until after the building was substantially comstatements of the arehicted honestly and in gond faith. trusting the

the Commonwealth and escaped punishment.

The auditor found that the market value of the labor and materials furnished by the plaintiff. not including the customary charge for the supervision of the work, was $\$ 33,490,30$, and that their total cost

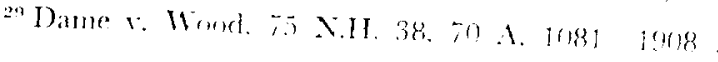


to the plaintiff was $\$ 32,950.96$. He found that the land and building have cost the defendant much more than their market value. The findings indicate that it was bad judgment on the part of the defendant to build such a structure upon the lot, and that the increase in the market value of the real estate, by reason of that which the plaintiff put upon it, is only $\$ 22,000$. The failure of the parties to discover the difference between their copies of the contract was caused by the frequently repeated fraudulent representations of the architect to each of them.

The plaintiff and the defendant were mistaken in supposing that they had made a binding contract for the construction of this building. Their minds never met in any agreement about the price. The labor and materials were furnished at the defendant's request and for the defendant's benefit. From this alone the law would imply a contract on the part of the defendant to pay for them. The fact that the parties supposed the price was fixed by a contract, when in fact there was no contract, does not prevent this implication, but leaves it as a natural result of their relations. Both parties understood and agreed that the work should be paid for, and both parties thought that they had agreed upon the price. Their mutual mistake in this particular left them with no express contract by which their rights and liabilities could be determined. The law implies an obligation to pay for what has been done and furnished under such circumstances, and the defendant, upon whose property the work was done, has no right to say that it is not to be paid for. The doctrine is not applicable to work upon real estate alone. The rule would be the same if the work and materials were used in the repair of a carriage, or of any other article of personal property, under a supposed contract with the owner, if, through a mutual mistake as to the supposed agreement upon the price, the contract became unenforceable.

This rule, that labor and materials furnished for a person at his request are to be paid for, prevails unless there is something in the circumstances or in the relations of the parties to rebut the ordinary presumption, as when the parties are husband and wife, or parent and child, living together in the same family, or when there is something else to indicate that the service is gratuitous. In a case like the present, when the understanding and agreement is that payment shall be made, it would be absurd to say that nothing should be paid because of a failure, through a misunderstanding, fully to agree.

The principle has often been applied when the ground for an implication of an agreement to pay was much less strong than in the present case. In Butterfield v. Byron, 153 Mass. 517, 27 N.F. 667, 12 L.R.A. 571, $25 \mathrm{Am}$. St. Rep. 654, where the owner was to do a part of the work in the erection of a building, and a contractor was to do the rest under an express contract for an agreed price, it was 
held that, when the building was destroved by lightning, so that the contract became impossible of performance, the contractor might recover, on a quantum meruit the fair value of the labor and materials that he had furnished. This was on the ground that, when the contract came to an end without the fault of either party, there was an implication that what was furnished was to be paid for, and if it could not be paid for under the contract it should be paid for on a quantum meruit. The same thing had been held previously in Cleary v. Sohier, 120 Mass. 210. As was pointed out in Butterfield v. Byron, at page 524 of 153 Mass., page 667 of 27 N.E. (12 L.R.A. 571, 25 Am. St. Rep. 654), the rule is analogous in principle to the right to recover on a quantum meruit for that which has been paid or furnished under an express contract, when there is a failure of the consideration. In the present case the labor and materials were furnished for a consideration supposed by both parties to exist in the form of an agreement by the defendant to pay a stipulated sum. Through the mistake of both parties there was no agreement, and that which was thought to be a valuable consideration failed. What was furnished to the defendant, in accordance with an agreement of both parties on the faith of this supposed consideration, must be paid for when the supposed consideration fails. The principle was applied and restated in Angus v. Scully, 176 Mass. 357, 57 N.E. 674, 49 L.R.A. 562, 79 Am. St. Rep. 318. The rule was said to be "that where one is to make repairs or do any other work on the house of another, under a special contract, and his contract becomes impossible of performance on account of the destruction of the house, without any fault on his part, then he may recover for what he has done." In Butterfield v. Byron it was said that under such circumstances "there is an implied assumpsit for what has properly been done by either of them, the law dealing with it as done at the request of the other, and creating a liability to pay for its value, to be determined by the price stipulated in the contract, or in some other way if the contract price cannot be made applicable." To the same effect is the decision in Young v. Chicopee, 186 Mass. 518, 72 N.E. 63. The fundamental principle was stated in Hebert v. Dewey, 191 Mass. 403-411, 77 N.E. 822, in this language: "It is a general rule that if an implied condition that fails is of the essence of the contract, and enters largely into the consideration, in such a way that there can be no substantial performance under the conditions, the whole contract will fail, and the parties may have reasonable compensation for what they have done in reliance upon it." In the present case the supposed agreement to pay for the plaintiff's work and materials was of the essence of the contract, and its only consideration. This failed, and with it the whole contract fell to the ground, and the parties may have reasonable compensation for what they have done in reliance upon it. . . 
If the law implies an agreement to pay, how much is to be paid? There is but one answer. The fair value of that which was furnished. No other rule can be applied. Inder certain conditions the price fixed by the contract might control in such cases. In this case there was no price fixed.

The defendant contends that because the erection of a Turkish bath house on Carver Street was not a profitable investment, and therefore, through a seeming error of judgment on the part of the defendant, the building did not add to the value of the land so much by a large sum as it cost, the plaintiff must suffer the consequences of the defendant's mistake and be precluded from recovery.

It is suggested that Gillis v. Cobe, 177 Mass. 590,59 N.E. 455, allows recovery only in reference to the pecuniary benefit derived by the owner from the change in the character of his real estate produced by the contractor, so that if, through his own bad judgment, the increase in the value of the property from the construction of the building is, as in this case, $\$ 10,000$ to $\$ 15,000$ less than the cost of the building to the contractor, the loss must fall upon the contractor if he seeks to recover under the rule stated in Hayward v. Leonard, 7 Pick. 181, $19 \mathrm{Am}$. Dec. 268. [This is an early case (1828) granting recovery in quasi-contract to a builder who had completed the building but breached the contract by departing from specifications.] The decision in Gillis v. Cobe was by four justices of the court, while three others of the justices thought that a part of the statement of law in the opinion reculted from a misunderstanding of the meaning and effect of previous decisions of this court. If, in a suit founded on the law laid down in Hayward v. Leonard, the decision in Gillis v. Cobe can be construed as largely diminishing the amount which the contractor would otherwise be entitled to recover for the erection of a building like that in the present case, it is to be noticed that this is the only decision in this Commonwealth in which there has seemed to be any practical difference between the views stated in the opinions in the case, in their application to the facts before the court, and the only one in which the court has had occasion to consider the subject. The evidence did not present for consideration the effect of unwise management by the owner upon a contractor's right to recover. It is also to be noticed that nowhere, so far as we have been able to discover, does the law, as applied to such cases in other jurisdictions, make the right of the contractor depend in any degree upon the profit or loss to the owner, arising from his wisdom or folly, or good fortune or bad fortune, in erecting the building upon his land.

Whatever view may be taken of the law stated in that decision, it has no application to the case at bar. In cases of that class the work is done under an express contract which is binding upon both parties to the dat of the trial. If the contractor has tried in gond faith to 
perform his contract, and has performed it substantially, the courts hold that it would be unjust for the owner to stand upon the contract and refuse to pay anything because of the contractor's failure to perform it fully. It is therefore held that, on equitable grounds, he must pay under a rule which will give him all equitable rights secured by the contract, whether in regard to damages for non-performance or the rate of payment prescribed. If the plaintiff's work and materials had been furnished under a binding contract which had been substantially but not perfectly performed, we should be obliged to determine whether, under the law so often stated in Massachusetts, he could be precluded from recovery by reason of the mistake or misfortune of this defendant in the management of his property. No such question arises on the facts now before us. In this case there was no express contract. The plaintiff's right is to recover upon an implied contract of an owner to pay for labor and materials used upon his property at his iequest. Whatever may be the reason or the measure of the right of recovery in cases like Hayward $v$. Leonard, in cases of the class to which the present one belongs the right does not depend upon the ultimate benefit received by the owner.

In Butterfield $\mathrm{v}$. Byron, ubi supra, the destruction of the defendant's property by lightning was what terminated the contract and gave the plaintiff his right to recover. In each of the cases of Cleary v. Sohier, Angus v. Scully and Young v. Chicopee, ubi supra, the same is true of the destruction of the owner's property by fire. In all cases to which this general principle has been applied, the recovery has been upon a quantum meruit for that which was furnished, subject to diminution of the amount by the price named in the contract, if that was very low. The right of recovery depends upon the plaintiff's having furnished property or labor, under circumstances which entitle him to be paid for it, not upon the ultimate benefit to the property of the owner at whose request it was furnished.

It follows that the plaintiff is entitled to recover the fair value of his labor and materials.

Exceptions sustained.

Why did not the court simply conclude that the defendant had agreed to pay $\$ 23,200$ and assess damages in that amount? What difference did it make that the plaintiff hadn': agreed? Was there any contract? Was there a promise? What is the amount of recover approved by the court? 
F. L. Wisdom and George C. Abel presented a claim against the estate of A. M. Harrison, deceased, of which T. T. Cotnam is administrator, for $\$ 2,000$ on account of surgical attention to the deceased, who was killed by being thrown from a street car.

The probate court allowed the account in the sum of $\$ 400$, and the administrator appealed to the circuit court.

The evidence showed that deceased received fatal injuries in a street car wreck; that while he was unconscious some person summoned Dr. Wisdom to attend him; that Dr. Wisdom called in Dr. Abel, an experienced surgeon, to assist him; that they found that the patient was suffering from a fracture of the temporal and parietal bones, and that it was necessary to perform the operation of trephining; that the patient lived only a short time after the operation, and never recovered consciousness.

Dr. Abel testified, over defendant's objection, that the charge of $\$ 2.000$ was based on the result of inquiry as to the financial condition of deceased's estate. It was further proved, over defendant's objection that deceased was a bachelor, and that his estate, which amounted to about $\$ 18,500$, including $\$ 10,000$ of insurance, would go to collateral heirs.

Various physicians testified as to the customary fees of doctors in similar cases, and fixed the amount at various sums ranging from $\$ 100$ to $\$ 2,000$. There was also evidence that the ability of the patient to pay is usually taken into consideration by surgeons in fixing their fee.

At the plaintiffs' request the court charged the jury as follows:

" 1 . If you find from the evidence that plaintiffs rendered professional services as physicians and surgeons to the deceased, A. M. Harrison, in a sudden emergency following the deceased's injury in a street car wreck, in an endeavor to save his life, then you are instructed that plaintiffs are entitled to recover from the estate of the said A. M. Harrison such sum as you may find from the evidence is a reasonable compensation for the services rendered.

"2. The character and importance of the operation, the responsibility resting upon the surgeon performing the operation, his experience and professional training, and the ability to pay of the person operated upon, are elements to be considered by you in determining what is a reasonable charge for the services performed by plaintiffs in the particular case."

In his opening statement to the jury, counsel for claimants stated that "Harrison was worth $\$ 8,000$, and had insurance, and his estate was left to collateral heirs, that is, to nephews and nieces." Counsel for defendant objected to such argument, but the court overruled the objection; and the defendant saved his exceptions.

Verdict for $\$ 650$ was returned in plaintiffs' faror. Defendant has appealed....

HILI, C.J. (after stating the facts) The reporter will state the issues and substance of the testimony, and set out instructions one and two given at instance of appellees. and it will be scen therefrom that 
instruction one amounted to a peremptory instruction to find for the appellees in some amount.

The first question is as to the correctness of this instruction. As indicated therein, the facts are that Mr. Harrison, appellant's intestate, was thrown from a street car, receiving serious injuries which rendered him unconscious, and while in that condition the appellees were notified of the accident and summoned to his assistance by some spectator, and performed a difficult operation in an effort to save his life, but they were unsuccessful, and he died without regaining consciousness. The appellant says: "Harrison was never conscious after his head struck the pavement. He did not and could not, expressly or impliedly, assent to the action of the appellees. He was without knowledge or will power. However merciful or benevolent may have been the intention of the appellees, a new rule of law, of contract by implication of law, will have to be established by this court in order to sustain the recovery." Appellant is right in saying that the recovery must be sustained by a contract by implication of law, but is not right in saying that it is a new rule of law, for such contracts are almost as old as the English system of jurisprudence. They are usually called "implied contracts"; more properly, they should be called quasi-contracts or constructive contracts. See 1 Page on Contracts, $\$ 14$; also 2 Page on Contracts, $\$ 771$.

The following excerpts from Sceva $v$. True, 53 N.H. 627, are peculiarly applicable here: "We regard it as well settled by the cases referred to in the briefs of counsel, many of which have been commented on at length by Mr. Shirley for the defendant, that an insane person, an idiot, or a person utterly bereft of all sense and reason by the sudden stroke of an accident or disease, may be held liable, in assumpsit, for necessaries furnished to him in good faith while in that unfortunate and helpless condition. And the reasons upon which this rests are too broad, as well as too sensible and humane, to be overborne by any deductions which a refined logic may make from the circumstances that in such cases there can be no contract or promise in fact--no meeting of the minds of the parties. The cases put it on the ground of an implied contract; and by this is not meant, as the defendant's counsel seems to suppose, an actual contract - that is, an actual meeting of the minds of the parties, an actual, mutual understanding, to be inferred from language, acts and circumstances by the jury--but a contract and promise, said to be implied by the law, where, in point of fact, there was no contract, no mutual understanding, and so no promise. The defendant's counsel says it is usurpation for the court to hold, as a matter of law, that there is a contract and a promise when all the evidence in the case shows that there was not a contract, nor the semblance of one. It is doubtless a legal fiction, invented and used for the sake of the remedy. If it was originally usurpation, certainly it has now become very inveterate, and firmly fixed in the body of the law."

... In its practical application, it sustains recovery for physicians and nurses who render services for infants, insane persons and drunkards. 2 Page on Contracts, $\$ 867,897,906$. And services rendered by physicians to persons unconscious or helpless by reason of injury or sickness are in the same situation as those rendered to persons incapable of contracting, such as the classes above described. Raoul $\therefore$ Newman, 59 Ga. 408 ; Mever $\therefore$ K. of P. 70 N.E. 111,178 N.Y. 
63, 64 L.R.A. 839. The court was therefore right in giving the instruction in question.

The defendant sought to require the plaintiff to prove, in addition to the value of the services, the benefit, if any, derived by the deceased from the operation, and alleges error in the court refusing to place this burden upon the phrsicians. The same question was iconsidered in Ladd v. Witte, 116 Wis. 35, 92 N.W. 365, where the court said: "That is not at all the test. So that a surgical optration be conceived and performed with due skill and care, the price to be paid therefor does not depend upon the result. The event fo generally lies with the forces of nature that all intelligent men knpw and understand that the surgeon is not responsible therefor. In absence of express agreement, the surgenn, who brings to such a service due skill and care earns the reasonable and customary price therefor, whether the outcome be beneficial to the patient or the reverse.'

The court permitted to go to the jury the fact that Mr. Harrison was a bachelor, and that his estate would go to his collateral relatives, and also permitted proof to be made of the value of the estate, which amounted to about $\$ 18,500$, including $\$ 10,000$ from accident and life insurance policies. There is a conflict in the authorilies as to whether it is proper to prove the value of the estate of a prrson for whom medical services were rendered, or the financial condition of the person receiving such services. In Robinson v. Campbell, 47 Iowa 625 , it was said: "There is no more reason why this charge should be enhanced on account of the ability of the defendants to pay than that the merchant should charge them more for a yard of floth, or the druggist for filling a prescription, or a laborer for a day's work." On the other hand, see Haley's Succession, 50 La. Ann. 840, 24 South. 285, and Lange v. Kearney, 4 N.Y. Supp. 14, 51 Hun 640, which was affirmed by the Court of Appeals, 127 N.Y. 676, 28 N.E. 255 , holding that the financial condition of the patient may be considered.

Whatever may be the true principle governing this matter in contracts, the court is of the opinion that the financial condition of a patient cannot be considered where there is no contract and recovery is sustained on a legal fiction which raises a contract in order to afford a remedy which the justice of the case requires. In Morrissett v. Wood, 123 Ala. 384, 26 South. 307, 82 Am. St. Rep. 127 , the court said: "The trial court erred in admitting testimony as to the value of the patient's estate, against the objection of the defendant. The inquiry was as to the value of the professional services rendened by the plaintiff to the defendant's testator, and, as the case was fresented below, the amount or value of the latter's estate could shed no legitimate light upon this issue nor aid in its elucidation. The cunb or amelioration of disease is as important to a poor man as it is 
at rich one, and, prima facie at least, the services rendered the one are of the same value as the same services rendered to the other. If there was a recognized usage obtaining in the premises here involved to graduate professional charges with reference to the financial condition of the person for whom such services are rendered, which had been so long established and so universally acted upon as to have ripened into a custom of such character that it might be considered that these services were rendered and accepted in contemplation of it, there is no hint of it in the evidence."

There was evidence in this case proving that it was customary for physicians to graduate their charges by the ability of the patient to pay, and hence, in regard to that element, this case differs from the Alabama case. But the value of the Alabama decision is the reason given which may admit such evidence, viz., because the custom would render the financial condition of the patient a factor to be contemplated by both parties when the services were rendered and accepted. The same thought, differently expressed, is found in Lange v. Kearney, 4 N.Y. Supp. 14, 51 Hun 640. This could not apply to a physician called in an emergency by some bystander to attend a stricken man whom he never saw or heard of before; and certainly the unconscious patient could not, in fact or in law, be held to have contemplated what charges the physician might properly bring against him. In order to admit such testimony, it must be assumed that the surgeon and patient each had in contemplation that the means of the patient would be one factor in determining the amount of the charge for the services rendered. While the law may admit such evidence as throwing light upon the contract and indicating what was really in contemplation when it was made, yet a different question is presented when there is no contract to be ascertained or construed, but mere fiction of law creating a contract where none existed in order that there might be a remedy for a right. This fiction merely requires a reasonable compensation for the services rendered. The services are the same, be the patient prince or pauper, and for them the surgeon is entitled to fair compensation for his time, service and skill. It was, therefore, error to admit this evidence and to instruct the jury in the second instruction that in determining what was a reasonable charge they could consider the "ability to pay of the person operated upon."

It was improper to let it go to the jury that Mr. Harrison was a bachelor, and that his estate was left to nieces and nephews. This was relevant to no issue in the case, and its effect might well have been prejudicial. While this verdict is no higher than some of the evidence would justify, yet it is much higher than some of the other evidence would justify, and hence it is impossible to say that this was a harmless error. 


\section{In the following case, Greenspan v. Slate, pay particular attention to the use ni precedent, by Judge Vanderbilt.}

Greenspan v. Slate

\section{N.J. 426,97 A.2d 390 (1953)}

\section{VANIIERTIIT, C. J.}

I. The Tacts arr! the Tssale.

Barbara Slate, the 17-ycar-oid danghter of the defeniants, injured a foot while playing basketionll at high school. Within two or three days it became excecdingly swollen and conspicunusly discolored so that she could walk on it only with the greatest difficulty and pain. Her parents, thinking it nothing more than a sprain, declined to provide her with merical air. The plaintiff, Garficld, a member of the hat of this State, discovered her plight by chance, when she was on a visit to his home in company with Berliley Badgett, his housekeeper's son, who was courting her.

Mr. Garfield promptly sent young Badgett, his mother and Barbara to the nearioy office of the plaintiff. Dr. Sidney Grecnspan, who discovered from $\mathrm{X}$-ray plates he made that a hone of Barbara's foot had heen fractured. He applied a cast which Barbara wore for about a month until it was removed by Dr. Greenspan. Meantime she used crutches. Barbara lived at home with her parents and the presence of the cast and her use of crutches were thus known to thcm. Clearly the broken bone that was causing much swelling, high discoloration and great pain necessitating the taking of X-ray plates, the applicution of a ract for a month and the llse of colitehes

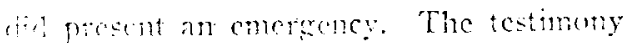
of The Girenemat that pernancut injury rent? have conenel if there had not heen proper bedical care and attention at the time is rencontradicted.

(1) the completion of his services Dr. Grewant rendered a bill to the parents of st: which they have refused to pay. Mr.

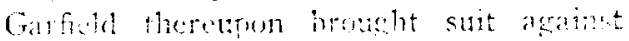
then on helali of Dr. Grenspan or himself in the alucrative. At the end of the plaintifs case the trial court granted the

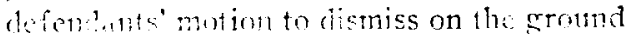
that D). Giecensun had acted without any

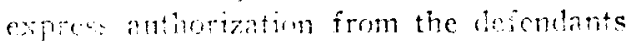
ane titut the proofs were insufficient in the

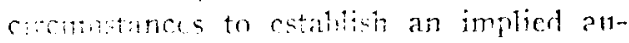
somation by them. On nppeal the Appel-

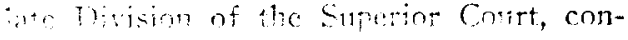

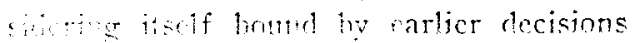

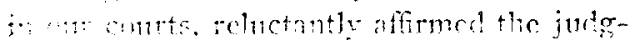

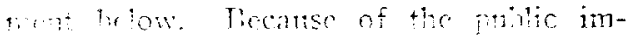
pretinter of the questim presented we mand entification. 1: Y T . O4 A.2d 6) (1053).

The question before $n$ s is whether or not the parents of an infant child are liable, in the alsence of a contract, express or implied in fact, for necrsaries fumished their chili in an merency.

\section{The Conflicting Views at Law a'vl in liguity.}

[1] Acowhere to Slackstone, "the duty of parent. to pongie for the mantenance

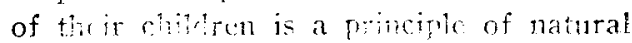
law." $1 \mathrm{~T}$. remm. H7. Elackstrme waxes eloquent "en tive nrincinte of "natural law" and quite ponpty so when the relations of paront and chidd are normal, but unconvincingly in the only ases with which the law should he concernod, i. e., when the parent fails to perform his natural duty. His reasoning is unconvincing, because in Blackstone's time the parcnt's duty at the common law was drastically restricted with respect to the method of enforcing it:

"No person is hound to provide a maintenance for his issue, unless where the children are impotent and unable to work, cither through infancy, disease, 
or accident, and then is only obliged to provide them with necessaries, the penalty on rcfusal being no more than 20s a month." Ibid. 449.

Neither the cliild nor any third party who ventured to supply the child with his necessarics had any cause of action against the parents to enforce the duty of support which Blackstone termed "a principle of natural law." The utter inadequacy of the common law in this stage of its development is especially manifest $i n$ meeting emergencies involving the life or limb of a child.

A parent might, it is true, make his child his agent, express or implied in fact, to make contracts for the child's necessaries:

"If a father does any specific act from which it may reasonably be inferred that he is anthorizing his son to contract a deht, he may he liable with respect to the debt so contracted; lut the mere moral obligation on the father to maintain his child affords no juference of a learal promise to pay his debts." Mortimore v. Mright, 6 M. \& W. 482 (Exch.Div.1840).

"If a father turns his son upon the world, his son's only resource, in the absence of anytling to show a contract on the father's part, is to apriy to the parish, and then proper stops will he taken to enforec the performance of the parents' legal dity." Sheiton v. Springett, 11 C.B. 452 (Com.P1.1351).

provided, of course, the child survives in the meantime! A child's need in these circumstances is quite as great as that of a neglected wife, but his rights and remedies are far less effective than hers, for she has an absolute right to pledge her hushand's credit for necessaries, even though there is no agency in fact existing such as the common law required in the case of a child to permit recovery. The law imposes the obligation on her husband for the benefit of the deserted wife without regard to whether or not there was any agency in fact, Strawbridge \& Clothier v. Sigle, 73 N.J.L. 419, 63 A. 865 (Sup.Ct.1906). The quasi-contractual nature of the husband's duty to a neglected wife is demonstrated by the fact that at common law it survives her death so as to include her funeral expenses, Mondock v. Gennrich, 21 A.2d 611, 19 N.J.Misc. 499 (Dist.Ct.1941).

The impact of these shortcomings of the common law remedy with respect to the maintenance of a child in comparison with that available to a neglected wife inevitably led the law courts to hold, in an effort to achicve a measure of justice, that "the authority of an infant to bind the father for nccessarics may be inferred from slight evidence (italics supplied)." Freeman v. Robinson, 38 N.J.L. 383, 384 (Sup.Ct.1S76). Thus in Fluck v. Tollemache, 171 E.R. 1078 (C.P.1823) it was said:

"An action can only be maintained against a person for clothes supplied to his son, either when he has ordered such clothes, and contracted to pay for them; or when they have been at first furnished without his knowledge, and he has adopted the contract afterwards: such adontion may be inferred from his sceing his son wear the clothes, and not returning them, or making at, or sonn after the time, when he knows of their being supplied, some objection."

But any such artificial basis for a fundamental doctrine as "infcrences from slight evilence" is not only unsound in principle but incfictive in operation, because it does not reach the cases where no express promise exists and where there is no "slight cridence" from which to infer a promise, and the cases not so reached are the ones where in simple justice a legal right and an adequate remedy are most needed. There is quite as great necessity for the imposition of a gucsi-contractual obligation by operation of law in favor of a neglected child as there is in the casc of a neglected wife.

The Court of Chancery within the limit of its juriscliction was not content to regard the father's duty as a mere principle of natural law, but it has sought to enforce it as a mattcr of equity. 'Thus Chancellor Benjamin Williamson applicd the prevailing American view as enunciated in Van Valkinburgh v. Watson, 13 Johns., N.Y., 480 7 Am.Dec. 395 (Sup.Ct.1816), that a parent is bound to provicle his infant child with necessarics and that if he neglects to do so; 
a third person may supply them and charge the parent therefor, in reaching his conclusions in Tomkins v. Tomkins, 11 N.J.Eq. 512, 517-518 (Ch.1858):

"The position taken by the complainant's counsel is, that a parent is under no legal obligation to support his child, and that whover furnishes a child with necessarics, must do it gratuitously: that no recovery can be had for such necessaries, inless they were furnished under an express contract with the parents. What was said by the juldges in the cases of Urmston v. Newcomer, 4 Ad. \& Ellis $899 ; 31$ E.C.L.; Mortimnre v. Wright, 6 M. \& W. 48 , would scem to sustain the position. Such is not the law in New Jersey. The law, as it has been adopted in this state, is as laid down by the court in Van Valkinburgh v. Watsnn and Watson, 13 J[ohns., N.Y.,] 480. A parent is hound to provide his infant children with necessaries; and if he neglect to do so, a third person may sunply thom, and charge the parent with the amount. But such thirel person must take notice of what is necessary for the infant, according to his sivation in life; and where the infant lives with his parent, and is provided for by him, a person furnishing necessaries camnot charge the parent. 'When the infant is sub potestate parentis, there must be a clear and palpable omission of duty, in that respect, on the part of the parent, in order to authorize any other person to act for, and charge the expense to the parent." "

But in Freeman v. Rohinson, 38 N.J.L. 383,384 (1876) we have a characteristic instance of the percnnial conflicts especially in earlier days of our courts of law and of equity. There the former Supreme Court, withnut citing the Tomkins case or Van Vallinhurgh v. Watson, supra, or the wight of concurring anthority in this country, held:

"The duty of, a faticr to provide maintenance for his ciniliren is a mere moral olligation. Except in cascs within the statute of Elizabeth, and by the procedure there pointed out, he is not legally compellable to perform this duty.

"No action can be maintained against a father for goods purchased on his credit hy his minor child, even though they he necessaries, unless the father las expressly or implicdly authorized the purchase on his credit. The authority of an infant to bind the father by contract for necessaries may be inferred from slight evidence. But, nevertheless, where the parent gives no authority, and enters into no contract, he is no more liable to pay a debt contracted by his child even for necessaries, than a mere stranger would be. 1 Parsons on Contracts 299; 1 Chitty on Contracts 210; Mortimore v. Wright, 6 M. \& W. 482; Raymond v. Loyl, 10 Barb. [483] 489; Plotts v. Roseh[u]ry, 4 Dutcher 146 [28 N.J.L. 146]. The mere moral obligation of a parent to maintain his child affords no legal inference of a promise to pay a debt contracted by him even for necesaries. Shelton v. Springett, 11 C.B. 452."

[2] Not only does this decision ignore American authoritics, but the English eases. cited by it were decided after the Revolution and accordingly are not part of our common law, In re Vince, 2 N.J. 443, 452, 67 A.2d 141 (1949). Plotts v. Rosebury, 28 N.J.L. 146 (Sup.Ct.1859), moteover, was not in point, involving, as it did, a case where a contract implied in fact might be inferred from previous transactions between the parties with reference to purchases made by the defendant's infant son. The Freeman case, although giving lip service to the doctrine of inferences from "slight eviclence", (38 N.J.L. at page 384) goes so far as to hold (pages 385-387) that not even an express promise by the defenclant to pay for the goods sold to his son, which certainly is more than "slight evidence"-indeed, it is the most explicit and nnambiguous evidence imaginablewould be supported by the defendants moral obligation to support his child, out 
of deference to technical rules of the law of considcration, in a situation that should not be governed by contract at all, but by the cquitable principle of quasi-contracts.

$[3,4]$ In contrast to these technicalities of the common law is Alling v. Alling, 52 N.J.Eq. 92, 27 A. 655 (Ch.1893). There Vice-Chancellor Pitney held:

"The question of the extent of the duty of a parent to support and maintain an infant child can be raiscd in this court only when the child has a fortune of its own. This court has no jurisdiction to compel a parent to support an infant child. In re Ryder, 11 Paige 185; Hodgens v. Hodgens, 4 Cl. \& F. 323. But when the infant child has an estate of its own and the question arises, directly or indirectly, how much, if anything, the parent shall be allowed out of such estate for the infant's support, the court will consider and determine the parent's duty toward the child and his or her ability to perform that duty. Such is the present case." (52 N.J.Eq. at page 96 , 27 A. at page 656.)

The learned vice-chancellor then proceeded to review at length the English Chanccry decisions and the American cases, both legal and equitable, holding that each parent is liable for the support of his infant children (52 N.J.Eq. at pages 97108), and came to the inevitable conclusion that (p. 108):

"For these rcasons I must decline to consider Pyatt v. Pyatt, [46 N.J.Eq. 285 [18 A. 1048] (E. \& A.1889)] as binding authority for the position that a widowed mother is entitled, without regard to her own ability, to full compensation and indemnity from her child's estate for support and maintenance rendered to it during infancy. Such a rule scems to me not to be warranted by the ancicnt authorities, influenced, as they werc, by the general disability of the wife resulting from coverture; much less does it seem in step with the modern statt1s of woman under the law and her general emancipation from the artificial re- straints of her previous condition and her ability to enter upon many pursuits once closed to her. On the contrary, I think that, in determining how much the widowed mother is to be allowed, we must take into consideration, as in all cases, all the circumstances-the mother's capacity and ability and the child's fortune. For instance, it would be monstrous, I think, to hold that if a widlowed mother was entitled in her own right to a fortune of $\$ 20,000$, or had a fixed income of $\$ 2,000$ a year, and had an only daughter, an infant, cntitled to a fortune of $\$ 5,000$, and should educate and support her daughter during infancy in a stylc commensurate with her own fortunc, she should be entitled to call upon that child when she came of age for all the expense of her support and education, though it might far exceed the child's fortune. And I think the result would be much the same if the mother had a well-cstablished earning ability to the same extent."

In equity, the parents' obligation to support and educate their children is much more than a principle of natural law; it is an obligation enforced wherever equity has jurisdiction on equitable principles in the light of the facts of the individual case. "The physical ability of the child to earn its bare food and clothing is not the test or gauge in this court of a parent's duty to support and educate it," (52 N.J.Eq. at page 96), nor does the fact that the child has an estate of its own excuse the parent from all obligation to it. In deternining the question of support the court will talic into consideration both the parents' ability to pay and the child's fortune.

In re Ganey, 93 N.J.Eq. 389, 116 A. 19 (Ch.1922), affirmed without opinion, $94 \mathrm{~N}$. J.Eq. 502, 119 A. 925 (E. \& A.1923), was a suit by the sister and brother-in-law of a lunatic for reimbursement out of the lunatic's estate for the maintenance of her daughter after the death of her husband. Relying expressly on the statement in Alling v. Alling, 52 N.J.Eq. 92, 96, $27 \mathrm{~A}$. 655,657 , supra, that "This court has no jurisdiction to compel a parent to support 
an infant child," and on the holding in Freeman v. Robinson, 38 N.J.L. 383, supra, that "The obligation of a father to maintain his child affords no legal inference of a promise to pay for necessaries," the trial court denied the claim. The reference to Freeman v. Robinson, however, is mere dictum, the Court of Chancery being witlout jurisdiction on the facts of the case under Alling v. Alling, supra. But the coirt was in error in supposing that equity lacked jurisdiction in all cases involving claims for the support of a child. As we have seen from our discussion of the Alling case, "The question of the extent of the duty of a parent to support and maintain an infant child can be raised in this court only when the child has a fortune of its own." 52 N.J.Eq. 92, 96, 27 A. $655,656$. All Vice-Chancellor Pitney implied by the statement relied on in In re Ganey that equity had no jurisdiction to compel a parent to support an infant child, as his entire discussion and conclusion clearly reveals, is a lack of jurisdiction to enforce a claim for money damages without the existence of some special equity.

Nor does the opinion in In re Ganey mention Tomkins v. Tomkins, 11 N.J.Eq. 512 , supra, the first expression of our courts on the issue under consideration. But Tomkins v. Tomkins has not yet spent its force, for in Murphy v. Murphy, 102 N.J. Eq. 552, 554, 141 A. 774 (E. \& A.1928), Judge White, speaking for a unanimous court, said :

"It may well be, although we do not so decide, that a husband may be liable, in a common law suit, to unpaid creditors who have supplied necessaries for the support of his minor children whose custody has been awarded to their mother under any alimony order for their support, which, under unexpected extraordinary circumstances, has proved insufficicnt (Tomkins $v$. Tomkins, 11 N.J.Eq. 512) ; * * *."

It is doubtful, moreover, if In re Ganey would have been decided as it was, if it had come up for consideration two years later, after the passage of R.S. 9:1-1, N. J.S.A. (L.1926, c. 201, § 1, p. 333) :
"The father and mother of a minor child are equally entitled to its services and earnings. If one of the parents be dead, has abandoned the child, ot has been deprived of its custody by court decree, the other is entitled to such services and earnings.

"The parents jointly may maintain an action for the loss of the wages or services of their minor child when such loss is occasioned by an injury, wrongfully or negligently inflicted upon such child. If one of the parents be dead, has abandoned the child, has been deprived of its custody by court decree or refuses to sue, the other may sue alone."

It is unthinkable that the Legislature would have granted such rights to the parents of a minor child without the implication of the corrclative duties of support and education by its parents.

The question before us has been considered or touched on in a number of other cases, all of which relate back to the doctrine of the Freeman case, without, however, impugning the holdings in the Tomkins or Alling cases, but it will serve no useful purpose to discuss or entimerate all of them; see, e. g., In re Rogers Estate, 96 N.J.Eq. 6, 7, 125 A. 318 (Ch.1924), Meier v. Plancr, 107 N.J.Eq. 398, 152 A. 246 (Ch. 1930) and Cohen v. Cohen, 6 N.J.Super. 26, 69 A.2d 752 (App.Div.1949). Suffice it to say that it appears that the question to be resolved here has not yet been passed on in the court of last resort, but that there are divergent views at law and in equity as to the fundamental nature of a parent's obligation to malntain an infant child awaiting decision.

The common law rule with reference to the support of minor children can only be understood in the light of the pertinent statutes. R.S. 44:4-104, N.J.S.A., is the modern counterpart of the statute referred to in 1 B1.Comm. 449, supra; it provides that where a father or mother deserts a child, the director of public welfare of the county welfare board may apply to the juvenile and domestic relations court for an 
order for "suitable support and maintenance" to be provided by the husband or wife. The court may compel the defendant to give reasonable security and by R.S. $44: 4-105$, N.J.S.A., may sequester the property of the defendant, appoint a receiver and apply the personal property and the rents and profits of the real estate toward such support and maintenance. By R.S. 30:4-60 and 66, N.J.S.A., similar provisions are made for insane children and by R.S. 30:4-176, N.J.S.A, for the indigent feeble-minded. As part of a matrimonial cause, an aggrieved wife may by N.J.S. $2 A: 34-24$, N.J.S.A., obtain suitable support for herself and her children, but if the neglected child is taken care of by others than a parent no duty of compensation is created by the common law nor is there at common law any forfeiture of the parent's rights in the child.

[5] To these civil obligations are added penalties and criminal sanctions. By R.S. 44:4-108 and R.S, 44:1-147, N.J.S.A., a father or mother who deserts a child or fails or neglects to provide for it may be adjudged a disorderly person, subject to a commitment for not exceeding 60 days. By N.J.S. $2 A: 100$, N.J.S.A. (section 1 of the Uniform Desertion and Nonsupport Act, 10 U.L.A. 1, 6), such misconduct is made a misdemeanor:

"Any husband or father who deserts and willfully neglects or refuses to provide for and maintain his wife and minor child or children, is guilty of a misdemeanor, and shall be punished by a fine of not more than $\$ 100$, or by imprisonment for not more than 1 year." N.J.S. 2 A:100-1, N.J.S.A.

"Any husbant who deserts or willfully neglects or refuses to provide for the suppont and maintenance of his wife, in destituts or necessints circumstances, or a parcnt who deserts or willfully neclects or refises to provide for the stmport and maintenance of his or her minot chile or cintiven, in destitute or necessitons circumstances, is mity of a mictomeanor. If a fine be imposed, the contem ma direct the same to he pail in whols or in nart to the wife, or to the guardian, custodian or trustec of said minor child or children." N.J.S. $2 A: 100-2$, N.J.S.A.

It is interesting to note in passing that the phrase "without lawful excuse" in the Uniform Act was omitted in adopting it here. This statute, insofar as minor children are concerned, is merely declaratory, for it was common law misdemeanor to neglect to provide for children where they suffer injury therefrom, R. v. Friend Russ. \& Ry. 20, 168 F. R. 662 (1802); R. v. Hogan, 2 Den. 277, 169 F. R. 504 (1851); R. v. Phillpot Dears 179, 169 E. R. 686 (1853); 9 Lalsbury's Laws of England (2d ed.) 443.

[6] The civil statutes seek to enforce not an obligation of a parent to the minor child, but a duty to the public if it becomes a public charge. The penal and criminal statutes, on the other hand, aim at coercing a defaulting parent into performing an obligation to a minor child for which the common law rule provides no civil remedy. Such a situation is distinctly anomalous and reflects the shortcomings of the common law in denying a civil recovery to the minor child or those who come to his aid. To quote Morris, "The Role of Criminal Statutes in Negligence Actions", 49 Col.L. Rev. 21, 22 (1949):

"Once the legislature has seen fit to punish conduct that falls within the immunity of a no-duty rule, there is all the more reason for reconsidering the civil law."

\section{The Preferable Rule.}

[7] As we have scen, there are no precedents in our courts of last resort so we are free to choose between the common law rulc and the Chancery principle in deciling the instant case. Normal instincts of humanity and plain common honesty as well as the substantial weight of judicial decisions in this country, the uniform rule of the civil haw in Europcan countries, and the unarimnis vicws of the text writers and the Rosictemont of the taw all combine to cicmonstrate the superiority of the equitable mic. Whatever objections may be raised theroto have been based either on fancicd 
fears as to its effect in operation, which long experience with it in many juristictions have shown to be altogether groundless, or on procedural misconcentions which slotyld long since have been discarded.

It shocks one's sensibilities to think that the common law would permit a wealthy parent to do no more than respond to the minimum demands of the Poor Law, while he himself is living in affucnce. It reflects a point of view which is utterly inconsistent with the common feclings of humanity, and whicl1 fortumately is found in relatively few instancs of mmanual conduct, yet it is against those inctances that the law must safeguard the offspring of an abnormal human being. The reasons for the prevailing American rule were well expressed in the early case of Finch v. Finch, 22 Conn. 411 (Sup.Ct.Err.1853):

"The case discloses nothing from which we can infer or presume that the mother is not of egrual pecuniary ability with the father to maintain their common offspring, nor whether the father has adequate ability to do it. There is a law of our universal humanity as extensive as our race, which impels parents, whether fathers or mothers, to protect and support their helpless children. It is a duty common to both, and the consequent obligation is common. Blackstone very properly says that 'the duty of parents to provide for the maintenance of their children is a principle of natural law. By begetting them, therefore, they have entered into a rrinutary obligation to endcavor, as far as in them lies, that the life which they have bestowed shall be supported and reserved. And this the children wil have a perfers wht of receiving maintenance from iheir parents.' This luty and this niligation have bcoin variously modified by the positive larrs of civilized countries, but fully recomized by all. Connected with this ohlicration of maintenance there is a parental privilege. The parent is cntitice to the custody and care of the chill which he sustains and to sucli scrice is it can render, and he has a right to exercise his own disere- tion in determining the fitness and necessity of the allowances to be made and of the support to be furnished to his children, for which he is to be made chargeable. * * * The legal liahility of the parent necessarily depends upon his or her ability to furnish the maintenance."

The substantial weight of authority supports this equitable, humanitarian view, 4 Vernicr, American Family Laws 56 (1936), 46 C.I. 1256, 1262, 1264, 67 C.J.S., Parcnt And Child, $\$ \S 14,15,16$, pases 686, 688, 607, 30 A.m.J11r. 630, 672, 686. See also 7 A.L.R. 1070, 10 A.L.R. 1138. The principles governing the application of the rule are set forth in three sections of the Restatement of the Law of Restitution (1937):

"§ 112. A person who without mistake, coercion or request has unconditionally conferred a benefit upon another is not entitled to restitution, except where the bencfit was conferred under circumstances making stuch action necessary for the protection of the interests of the other or of third persons.

"§ 113. A person who has performed the noncontractual duty of another by stpplying a third person with necessaries which in violation of such duty the other had failed to supply, although acting without the other's knowledge or consent, is entitled to restitution thercfor from the other if he acted unofficiously and with intent to charge therefor.

"§ 114. A person who has performed the duty of another by supplying a third person with necessaries, although acting without the other's knowledge or consent, is entitled to restitution from the other therefor if (a) he acted unofficiously and with intent to charge therefor, and (b) the things or services supplicd were inmediately necessary to prevent serious bodily harm to or suffering by such person."

The course of the Roman law and the modern ciril law of Western Europe, which is mascl on it, suggests that the 
common law rule, which we are now discarling in favor of the cquitable doctrine, may be merely an instance of early undevelnped law. In the Roman law the dity of a father to support his child was enforced only by criminal proceedings, Ratin, Handhook of Roman Law 108 (19.27), lut in the modern civil law the obligation of the parents is direct:

"The dity of taling care of the children's stipport mutil such time as they are capalle of supporting thon. selves is primarily incumbent on the father. Their physical care is pri.. marily incumbent on the mother. In the event that the father is indigent the duty to take core of the children's support and in the event of the iather's death [the luty to take care of] the chiliten's crlacation in general, is primarily incumbent on the mother. In the event that the mother shall not survive [the fither] or is indigent, such duty is iumbent tpon the paternal grandparents ur, enbordinately, on the maternal grandparents," Austrian Civil Law, sec. 143.

"Spouses are jointly obligated, by reason of the solc fact of contracting marriage, to feed, support and educate their children." French Civil Code, Art. 203.

"Relatives in the line of direct descendants are under the obligation of supporting each other." German Civil Code, sec. 1601." Only the one who is incapable of supporting himself is entitled to support. An infant unmarried child may require his parents to support him although he own property, to the extent to which the income from his property nid from his own work are not su "wnt for his support." Ihid., scc. : "?.'

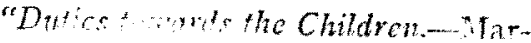
riagc immos limon both spotses the

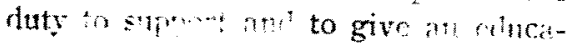

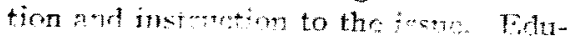
cation and instaction mus con form to moral principles." Italian civi Colc, Art. 147.
"Contribution to the Burdens.--The duty of supporting and of giving an education and instruction to the issue is borne by the father and by the mother in proportion to their property, including in the mother's contribution income from her dowry. If the parents do not have sufficient means, such duty falls on the other ascendants according to their order of proximity to the infants." Ibid., Art. 148.

"The father and the mother and the cinld we each other the core and assistane which are required in the interest of the family." Swiss Civil Cole, Art. 271. "The father and the mother shall boar the expenses for the support and education of the child [and they shall share in thenl] according to their matrimonial recrimc. If they are in need or if the child causes cxtraordinary expenses or under other exceptionnl circumstances, the supervism ing [juJicial] anthority may allow the father and the mother to subject the property of the infant child to contribution for his support and education to the extent fixed by it." Ibid., Art. 272 .

The reason for the early common law rule is to be found in part in the procedural limitations of the common law. The common law was slow in permiting the use of assumpit in suits other than our express contracts or contracts impled in fact, Ames, Implich Assumpit, in Irctures on Legal History, 149. Ouasimentwets in which the obligation was created by law, ibid. 160 , were recognized very gratually, ibid. 162, and their trice natiro was even slower in being perceired. Often ohligntions imposed in law were conceived of as true contracts implied in fact and gratually extender thy the vee of a foction to coner obligations implot in law. Thus, it was much

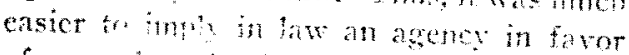
of a nestedes wife arningt her husband, from the wet wat wives were commonly agents of their imsbank in varme affars, than it was to imply an obligation in law for suppert in favor of children, who were far less ficquently agents of their parems. 
It was not until the appearance of Keener on Quasi Contracts in 1889 that the theory of that subject was elaborated, although Dean Ames outlined the subject in the article above mentioned. There is no reason why the parents' right to the scrvices and earnings of a child should not have supported the parents' obligation to support and educate him, Oshorn v. Allen, 26 N.J. L. 388, 391 (Sup.Ct.1857), to the same degree that the wife's obligation to her husband is decmed in law to support her agency to bind him for necessarics, when he deserts her or consents to their separation, Emery v. Neighhour, 7 N.I.I. 142, 146 (Sup.Ct.1824); Vusler v. Cox, 53 N.J.J. $516,518,22$ A. $347(S 1 n$ Ct. 18$) 1)$, or otherwise neglects to furnish hro with necessaries, Sterling v. Potts, 5 N. I.L. 773 (Sup. Ct.1820). There is no greater danger of injury to the family in the rase of the child than in the case of the wife, and the need of a child may be just as great as hers or even greater.

[8] Normally suits for the recovery of necessaries furmished a child will be brought in the Law Division, but if the isste of suprort involves sircial equities such as a cail on the minor's separate estate for contrihution, Nllingr v. Al'ing, 52 N.J. Eq. 92, 27 A. $65 \%$ sirra, or is part of a matrimonial action under N.J.S. $2 A: 34-24$, N.J.S.A., sumra, the procociling will be brought in the Chancery Division as heretofore.

IV. Services Rendered in an Emergency.

[9] There can be no doubt that the physician plaintiff comes within the terms of sections 113 and 114 of the Restatcment of the Jaw of Restitution above quoted. The defendants were under an obligation as part of their donty to smoport and educate their daughter, to provide her with medical services both under normal circumstances and in emcrgencies.

The evidence is uncontradicted that an emergency existed. The parents had refused to provide their child with medical attention with the result that permanent injury would have encuted but for the immediate treatment rendered by the physician plaintiff. Cleary they knew that the serv- ices were necessary and that a physician would expect payment for his services. Here the defendants permitted their daughter not only to use the cast and crutches for a month, but to return to the doctor at the end of the month to have the cast removed. Having retained the benefit of the physician plaintiff's services and permitted their daughter to return to him for further services, they are in no position in the circumstances of the case to complain that he acted without notice to them. He did not act officiously, and as a physician in practice of his profession he naturally intended to charge for his services. All the necessary elements are present to impose on the defendants the legal obligation to pay for medical cxpenses rendered to their child in an emergency.

The judgment below is reversed. Judgment will be entered here in favor of the plaintiff, Dr. Sidney Greenspan, for $\$ 45$.

For reversal: Chief Justice VANDERBIJT, and Justices OLIPHANT, BURLING, IACOBS and BRENNAN-5.

For affirmance: Justices HEHER and W $\triangle$ CHENFEI_D-2. 
OLWELL V. NYE \& NISSEN CO.

Supreme Court of Washington

26 Wash. 2d 282, 173 P.2d 652, 169 A.L.R. 139 (1946)

Mallery, Justice. On May 6, 1940, plaintiff, E. L. Olwell, sold and transferred to the defendant corporation his one-half interest in Puget Sound Egg Packers, a Washington corporation having its principal place of business in Tacoma. By the terms of the agreement, the plaintiff was to retain full ownership in an "Eggsact" egg-washing machine, formerly used by Puget Sound Egg Packers. The defendant promised to make it available for delivery to the plaintiff on or before June 15, 1940. It appears that the plaintiff arranged for and had the machine stored in a space adjacent to the premises occupied by the defendant but not covered by its lease. Due to the scarcity of labor immediately after the outbreak of the war, defendant's treasurer, without the knowledge or consent of the plaintiff, ordered the egg washer taken out of storage. The machine was put into operation by defendant on May 31, 1941, and thereafter, for a period of three years, was used approximately one day a weck in the regular course of the defendant's business. Plaintiff first discovered this use in January or February of 1945 , when he happened to be at the plant on business and heard the machine operating. Thereupon, plaintiff offered to sell the machine to defendant for $\$ 600$ or half of its original cost in 1929. A counteroffer of $\$ 50$ was refused, and, approximately one month later, this action was commenced to recover the reasonable value of defendant's use of the machine, and praying for $\$ 25$ per month from the commencement of the unauthorized use until the time of trial. A second cause of action was alleged, but was not pressed and hence is not here involved. The court entered judgment for plaintiff in the amount of $\$ 10$ per week for the period of 156 weeks covered by the statute of limitations, or $\$ 1,560$, and gave the plaintiff his costs.

Defendant has appealed to this court, assigning error upon the judgment, upon the trial of the cause on the theory of unjust enrichment, upon the amount of damages, and upon the court's refusal to make a finding as to the value of the machine, and in refusing to consider such value in meassuring damages.

The theory of the respondent was that the tort of conversion could be "waived" and suit brought in quasi-contract, upon a contract implied in law, to recover, as restitution, the profits which inured to appellant as a result of its wrongful use of the machine. With this the trial court agreed and, in its findings of facts, found that the use of the machine "resulted in a benefit to the users, in that said use saves the users approximately $\$ 1.43$ per hour of use as against the expense which would be incurred were eggs to be washed by hand; that said machine was used by Puget Sound Egg Packers and defendant, on an average of one day per week from May of 1941, until February of 1945 at an average saving of $\$ 10.00$ per each day of use."

In substance, the argument presented by the assignments of error is that the principle of injust enrichment, or quasi-contract, is not of universal application but is imposed only in exceptional cases because of special facts and circumstances and in favor of particular persons; that respondent had an adequate remedy in an action at 
law for replevin or claim and delivery; that any damages awarded to the plaintiff should be based upon the use or rental value of the machine and should bear some reasonable relation to its market value. Appellant therefore contends that the amount of the judgment is excessive.

It is uniformly held that in cases where the defendant tortfeasor has benefited by his wrong, the plaintiff may elect to "waive the tort" and bring an action in assumpsit for restitution. Such an action arises out of a duty imposed by law devolving upon the defendant to repay an unjust and unmerited enrichment. Woodward, The Law of Quasi-Contracts \$272 (2), p. 439; Keener on Quasi-Contracts, p. 160. Sec also, Professor Corbin's articles, "Waiver of Tort and Suit in Assumpsit," 19 Yale Law Journal, p. 221, and "Quasi-Contractual Obligations," 21 Yale Law Journal, p. 533.

It is clear that the saving in labor cost which appellant derived from its use of respondent's machine constituted a benefit.

According to the Restatement of Restitution, $\$ 1$ (b), p. 12,

"A person confers a henefit upon another if he gives to the other possession of or some other interest in money, land, rhattels, or choses in action, performs services beneficial to or at the request of the other, satisfies a debt or a duty of the other, or in any wily adds to the other's sccurity or advantage. He confers a benefit not only where he adds to the property of another, but also where he saves the other from expense or loss. 'The word 'bencfit,' therefore, denotes any form of advantage." (Italics by the court.)

It is also necessary to show that, while appellant benefited from its use of the egg-washing machine, respondent thereby incurred a loss. It is argucd by appcllant that, since the machine was put into storage by respondent, who had no present use for it, and for a period of almost three years did not know that appellant was operating it and since it was not injured by its operation and the appellant never adversely claimed any title to it, nor contested respondent's right of repossession upon the latter's discovery of the wrongful opcration, that the respondent was not damaged, becanse he is as well off as if the machine had not been used by appellant.

The very essence of the nature of property is the right to its exclusive use. Without it, no beneficial right remains. However plausible, the appellant cannot be heard to sav that its wrongful invasion of the respondent's property right to exclusive use is not a loss compensable in law. To hold otherwise would be subversive of all property rights, since its use was admittedly wrongful and without claim of right. The theory of unjust enrichment is applicabic in such a case.

We agree with appellant that rexpondent could have elected a "common garden variety of action," as he calls it, for the recovery of damages. It is also true that except where provided for by statute, punitive damages are not allowed, the basic measure for the recovery of damages in this statc being compensation. If, then, respondent had been limited to redress in tort for damages, as appellant contends, the court below would be in error in refusing to make a finding as to the value of the machine. In such case the award of damages must bear a reasonable rclation to the valne of the property. Hoff $v$. Lester, Wash., 168 P.2d 409. 
But respondent here had an election. He chose rather to waive his right of action in tort and to sue in assumpsit on the implied contract. Having so elected, he is entitled to the measure of restoration which accompanies the remedy.

"Actions for restitution have for their primary purpose taking from the defendant and restoring to the plaintiff something to which the plaintiff is entitled, or if this is not done, causing the defendant to pay the plaintiff an amount which will restore the plaintiff to the position in which he was before the defendant received the benefit. If the value of what was received and what was lost were always equal, there would be no substantial problem as to the amount of recovery, since actions of restitution are not punitive. In fact, however, the plaintiff frequently has lost more than the defendant has gained, and sometimes the defendant has gained more than the plaintiff has lost.

"In such cases the measure of restitution is determined with reference to the tortiousness of the defendant's conduct or the negligence or other fault of one or both of the parties in creating the situation giving rise to the right to restitution. If the defendant was tortious in his acquisition of the benefit he is required to pay for what the other has lost although that is more than the recipient benefited. If he was consciously tortious in acquiring the benefit, he is also deprived of any profit derived from his subsequent dealing with it. If he was no more at fault than the claimant, he is not required to pay for losses in excess of benefit received by him and he is permitted to retain gains which result from his dealing with the property." (Jtalics by the court.) Restatement of Restitution, pp. 595, 596.

Respondent may recover the profit derived by the appellant from the use of the machine.

Respondent has prayed "on his first cause of action for the sum of $\$ 25.00$ per month from the time defendant first cormenced to use said machine subsequent to May 1940 (1941) until present time."

In computing judgment, the court below computed rocovery on the basis of $\$ 10$ per week. This makes the judgment escerive since it cannot exceed the amount praved for....

We therefore direct the trial court to reduce the judgment, based upon the prayer of the complaint, in $\$ 25$ per month for thirty-six costs.

The judgment as modified is affirmer. Apnellant will recover its 
HART צ. E. P. DUTTON \& CO.

Supreme Court of New York

197 Misc. 274, 93 N.Y.S.2d 871

Af'd, 277 App. Div. 935, 98 N.Y.S.2d 773

Reargument and appeal denied, 277 App. Div. 962, 90 X.Y.S.2d $1014(1949)$

Malpass, Justice. A motion has been made by the defendant for judgment dismissing the complaint upon the grounds that the causes of action alleged in the complaint are barred by the statute of limitations and that the complaint does not state facts sufficient to constitute a cause of action.

The complaint sets forth two separate causes of action based upon alleged libelous statements claimed by the plaintiff to have been contained in a book entitled "Under Cover" which, according to the complaint was published by the defendant on or about July $18,1943$. It is alleged in the complaint that the book contained statements which were libelous and defamatory of the plaintiff and numerous other persons, the names and identities of some of whom are unknown to 1 the plaintiff. The plaintiff has brought the action "on behalf of himself and all other persons falsely and unjustly held out to the public

- as traitors to America in time of war, and/or agents of the Axis enemy, in time of war, in the book 'Under Cover', similarly situated." In the first cause of action set forth in the complaint the plaintiff alleges "that solely by reason of the aforesaid libelous publication, the plaintiff and those similarly situated, have suffered great humiliation and loss of reputation; have been held out to great hatred and contempt; have been exposed to mob hysteria; and have been placed in great fear for the safety of themselves and their families; and in other respects have suffered damage." It is further alleged in the first cause of action that the defendant sold a large number of copies of the book and has received in sales from the book, royalties, etc., proceeds which amount to the sum of $\$ 2,450,000$ "which money defendant had and received to the use of the plaintiff, and those similarly situated; and further, that five years have elapsed, between the receipt of said monies and the commencement of this action," and "that on or about March 15 th, 1949, the plaintiff demanded of the defendant that it pay the said proceeds of the book 'Under Cover', to the plaintiff for himself and for those similarly situated, but the defendant neglected and refused, and still neglects and refuses to pay the said proceeds, or any part thereof." The second cause of action is a repetition of the allegations contained in the first cause of action and in addition alleges that the defendant maliciously contrived to convey to the public the idea that the plaintiff and those similarly situated were enemies of, or traitors to the United States of America in time of war; that he was understood as meaning that they were traitors, and/or agents of the 
enemy, by those who read the book; and further, that the defendant intended to profit through the sale and circulation of this libelous matter, and did so profit, to the extent already set forth." The prayer of the complaint is for judgment in favor of the plaintiff and those similarly situated for the sum of two million, four hundred and fifty thousand dollars $(\$ 2,450,000)$, the amount alleged to have been received by the defendant, together with interest from March 15, 1944 , which it may be assumed, is the date when the plaintiff claims the defendant received the profits derived from the publication of the book.

The defendant urges that the complaint fails to allege facts sufficient to constitute any cause of action except one to recover damages for libel and that such an action is barred by the statute of limitations. Section 51 of the Civil Practice Act provides that an action to recover damages for "libel or slander" must be brought within one year after the cause of action has accrued. A cause of action for libelous statements contained in a book accrues when the book is released by the publisher for sale in accord with trade practice. Gregoire v. G. P. Putnam's Sons, 298 N.Y. 119-125, 81 N.E.2d 45, 48. The complaint states "That on or about the 18th day of July, 1943, while America was at war with Germany and Japan, the defendant published, distributed, advertised, and circulated a book entitled 'Under Cover." The action was begun in March, 1949. Bevond doubt, if plaintiff's action is deemed to be one to recover damages for libel, the action is barred by the statute.

The plaintiff contends that the action is not an action to recover damages for libel but is an action for money had and received and that subdivision 1 of section 48 of the Civil Practice Act is the applicable statute of limitation. This section provides that "an action [based] upon a contract obligation or liability express or implied," must be commenced within six years after the cause of action has accrued. The plaintiff contends that the plaintiff has the right to waive his action for the tort and sue the defendant, in assumpsit, for the moneys which the defendant realized from the sale of the book and certain rights in connection therewith, on the theory that the law implies a contract on the part of a tort-feasor to account to the party injured by the tort for any moneys acquired by the tortfeasor in the commission of the tort. The plaintiff contends that the law forbids that any person shall profit by reason of a wrongful act against another and that to permit the defendant to retain the proceeds derived from the publication of the book containing the libelous statements would result in the unjust enrichment of the defendant and that the law will imply a contract on the part of the defendant to pay the plaintiff and those persons similarly situated the moneys so received. 
The question is squarely presented as to whether one who claims to have been damaged by the publication of a libel, under the circumstances alleged in this complaint, may waive the tort and maintain an action in assumpsit to recover the proceeds or profits derived from the publication of the libel. This seems to be a novel proposition and the briefs submitted by counsel for both parties fail to disclose any case where the precise question has been adjudicated nor has a rather extensive research by the Court revealed any such case.

There are certain cases in which a person injured by a tort may waive the tort and sue for breach of what has been termed implied or quasi contract. Such right is not allowed in all cases, 1 Cooley on Torts, 4th ed., $\S 61$. "The torts which it has been held can be waived are usually, conversion, trespass to land or goods, deceit and the action for extorting money by threats." Salmond on the Law of Torts, 8th ed., p. 194. It is noteworthy that in all of those cases the tort involved an injury to property. 'Section 37-a of the General Construction Law provides that libel is a personal injury.

An action in assumpsit lies against one who has obtained money from another by a fraud; the tort may be waived and an action may be brought founded on an implied promise to return the money wrongfully obtained. Rothchild v. Mack, 115 N.Y. 1, 8, 21 N.E. 726,728 . Also an action in assumpsit lies against one who has converted money or property belonging to another. People v. Wood, 121 N.Y. 522, 528-529; Terry et al, v. Munger, 121 N.Y. 161, 24 N.E. 272, 8 L.R.A. 216, 18 Am. St. Rep. 803. The right to bring action in assumpsit ex contractu cannot be created simply by a waiving of the tort but this right depends upon circumstances existing from which a contract will be implied. ...

The right to waive a tort and sue in assumpsit is dependent upon the existence of a contractual relationship either express or implied and in most cases the question arises as to the existence of an implied contract. Implied contracts are those implied in fact or implied in law. In Miller v. Schloss, 218 N.Y. 400, 406-407, 113 N.E. 337, 338, the court says:

"The courts recognize by the language of their opinions two classes of implied contracts. The one class consists of those contracts which are evidenced by the acts of the parties and not by their verbal or written words-true contracts which rest upon an implied promise in fact. The second class consists of contracts implied by the law where none in fact exist- quasi or constructive contracts created by law and not by the intentions of the parties. A contract cannot be implied in fact where the facts are inconsistent with its existence, or against the declaration of the party to be charged, or where there is an express contract covering the subject-matter involved, or against the inten- 
tion or understanding of the parties, or where an express promise would be contrary to law. The assent of the person to be charged is necessary and unless he has conducted himself in such a manner that his assent may fairly be inferred he has not contracted. . . . A quasi or constructive contract rests upon the equitable principle that a person shall not be-allowed to enrich himself unjustly at the expense of another. In truth it is not a contract or promise at all. It is an obligation which the law creates, in the absence of any agreement, when and because the acts of the parties or others have placed in the possession of one person monev, or its equivalent, under such circumstances that in equity and good conscience he ought not to retain it, and which ex aequo et bono belongs to another. Duty, and not a promise or agreement or intention of the person sought to be charged, defines it. It is fictitiously deemed contractual, in order to fit the cause of action to the contractual remedv."

The foregoing is cited with approval by Judge Lewis in Grombach Productions, Inc. v. Waring, 293 N.Y. 609, 59 N.E.2d 425, 428. Under these decisions it must be held that the complaint in this action contains no allegations which would establish a contract "implied in fact." The question then presents itself, as to whether the allegations of the complaint are such as to create a contract "implied in law" so as to enable the plaintiff to maintain the action as one $e x$ contractu rather than in tort.

An action based upon invasion of one's right of privacy may be said to resemble, in many respects, an action based upon libel. In Street on Foundations of Legal Liability, Volune 1, page 319, it is stated: "It is supposed that if such a right is to be born it must come in some way from the law of libel. Those who contend for a right of personal security broad enough to include a general right 'to be let alone' would not perhaps admit this, but unquestionably the law of libel furnishes a nearer approach to the indicated goal than any other branch of tort."

It would seem, therefore, that any adjudications where damages for invasion of one's right of privacy is involved might well be of assistance in determining the instant motion. In Bunnell v. Keystone Varnish Co., 254 App. Div. 885-886, 5 N.Y.S.2d 415, the Court said: "The plaintiff has no cause of action on quasi-contract. An action under section 51 of the Civil Rights Law is the plaintiff's sole remedy for the unauthorized use of her name (Binns v. Vitagraph Co. [of America], 210 N.Y. 51, 103 N.E. 1108, L.R.A. 1915C, 839, Ann. Cas. $1915 \mathrm{~B}, 1024)$ and the alleged unjust enrichment of the defendant is a part of that cause of action. Cf. Franklin v. Columbia Pictures Corp., 246 App. Div. 35-37, 284 N.Y.S. 96 [98]; affirmed 271 N.Y. 554, 2 N.E.2d 691." (Italics by the court.) 
In Cason v. Baskin, 155 Fla. 198, 20 So. 2d 243, p. 234, 108 A.L.R. 430, the Supreme Court of Florida, said: "The demurrer to the fourth count was also properly sustained by the trial court. That count in effect claimed that the plaintiff was entitled to share in the profits received by the defendant for the publication and sale of her book to the extent of one hundred thousand dollars... that many copies of the book were purchased and paid for by persons of Alarhua County and throughout the United States and that thereby the defendant had received great financial profit, and has thus become unjustly enriched at the expense of and to the damage of plaintiff. to the extent of one hundred thousand dollars.... In our opinion this count states no cause of action." (Italics by the court.)

These are the only cases to which my attention has been directed where an attempt has been made to recnver the profits or proceeds derived from the invasion of a person's right of privacy. The theory of the plaintiff in each of these cases was substantially the same as is plaintiff's in the instant action. In each case the court held that the plaintiff could not recnver profits on the hasis of a quasi contract. The reasons which support this rule in regard to right of privacy are applicable to actions based upon libel.

Is was stated in Miller $、$ Schloss (supra p. 407). "A quasi or constructive contract rests upon the equitable principle that a person should not be allowed to enrich himself unjustly at the expense of another." and is created when "because iof? the acts of the parties" a person is possessed of money or property which in equity or good conscience he should not retain. The appliration of this rule requires inquiry. not only inte the arts of the defendant, but also the acts of the plaintiff. One who publishes a libel, especially if done maliciously, as charged in this complaint. is guilty of conduct which makes him liable for damages. In action for damages affords the plaintiff full compensation for an injuries which he has suffered. In addition to compensatory ramages he may recover punitive damages if proper foundation is establistied by the pronf. The law requires that a plaintiff must bring his artion to rernver such damages within one year. It would seem that it is not equitable and just to permit a person, who has been the subject of a libelous article published in a bonk, to acquiesse in or permit the sale and distribution of such book to continue for a period of nearly six years without taking any steps whatsoever to protest or stop the sale and distritution of the book and then to maintain an action for the profics derived from the sale and distribution of the book. The publication of a honk entails great expense and effort on the part of the publisher and the profits derived therefron are che in Jarce measure to elements outcide of the printed matter contained therein. To permit wich an action as the plaintif? 
has brought, under the circumstances alleged in the complaint, would have the effect of making the publisher for a period of years, the servant of the plaintiff, who, despite his failure to avail himself of a complete legal remedy, may now assert a right to the fruits of the defendant's labor and investment even beyond that which may flow from the alleged libel. Such a situation would be incquitable and would result in the unjust enrichment of the plaintiff. Under such circumstances no contract should be "implied in law" requiring the defendant to account to the plaintiff for profits derived from the publication of the book. . .

The plaintiff asserts that the one-year statute of limitations is not applicable for the reason that his action is not for damages but is in assumpsit for moneys had and received and is based upon an implied contract and the six-year statute applies. In his brief, plaintiff's counsel states: "To call this an action for 'damages" for libel, ignores basic facts. To reiterate, we are waiving these damages, and suing for moner 'had and reccived. We are undrrtaking to prove additional facts never before pleaded in "libel suit: namely, that the defendant 'had and received money by virtue of the publication of his libclous publication." Whatever the plaintiff may call the action, it is based upon the tort of lihel and in the absence of any statute or common law authority, it must be considered as an action for damages for libel within the meaning of Section 51 of the Civil Practice Act. In applying the statute of limitations the Court should look for the reality and the essence of the action and not its mere name. . .

The plaintiff should not be permitted to avoid the effect of the statute of limitations by attempting to pleard a cause of action for which there is no authority in law. Lucci r. Engel. Sup., 73 N.Y.S.2d 78.

Libel has been a field of much litigation both in Fngland and this country and during the course of the vears many judicial decisions have been handed down in libel actinns. It js significant that in none of these cases has an action such as is brousht by the plaintiff in this case been instituted. The plaintiff recognizes this fact and states: "We are undertaking to prove additional facts never before pleaded in a libel sit, namely, that the defendant had and received money by virtue of his libelous publication." The absence of attempts to bring an action similar to the instant one is evidence of the recognition by the lesal profession and the courts that such an action would not lie under the common law. In Near. Minnesota. 283

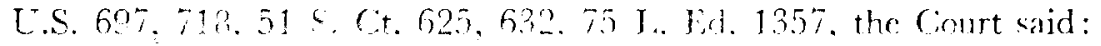
"The fact that for astwoximately one bunderd and fifty groms there has been almost an entire aboner of attompts to improse previous restraints upon publications relating in the malfersance of public 
officers is significant of the deep-seated conviction that such restraints would violate constitutional right." (Italics by the court.)

The development of the law of libel has been accompanied in this country with the right of freedom of speech and freedom of the press which is guaranteed by the Federal and State Constitutions. ...

The State which guarantees the freedom, punishes its abuse, and accords to the individual whose reputation has been attacked, remedies for the injuries sustained. The remedies thus given at common law, regulated in certain respects by statute, are called actions of libel and slander, whose object is the recovery of money for the injury. Seelman on Law of Libel and Slander, p. 1. It is evident that the right to recover based upon libel has been limited to the recovery of damages under the common law and statutes applicable thereto. It would seem, therefore, that the law is so well established that an innovation such as the plaintiff seeks in this action would impose new and unnecessary hazards upon publishers and would be contrary to the policy of our law. The reason for such conclusion can no better be expressed than in the language of the Court of Appeals in Roberson v. Rochester Folding Box Co., 171 N.Y. 538-556, 64 N.E. 442, 447, 59 L.R.A. 478, 89 Am. St. Rep. 828:

"An examination of the authorities leads us to the conclusion that the so-called 'right of privacy' has not as yet found an abiding place in our jurisprudence, and, as we view it, the doctrine cannot now be incorporated without doing violence to settled principles of law by which the profession and the public have long been guided."

In my opinion the complaint herein fails to state any cause of action other than a cause of action to recover damages for libel and such cause of action is barred by the statute of limitations. . . . 